UNIVERSIDADE DE SÃO PAULO

ESCOLA DE ARTES, CIÊNCIAS E HUMANIDADES

PROGRAMA DE PÓS-GRADUAÇÃO EM ESTUDOS CULTURAIS

\title{
MARCIA FERREIRA MATOS
}

A cultura surda nos cursos de licenciatura:

práticas e perspectivas no ensino da Língua Brasileira de Sinais 
MARCIA FERREIRA MATOS

A cultura surda nos cursos de licenciatura:

práticas e perspectivas no ensino da Língua Brasileira de Sinais

Dissertação apresentada à Escola de Artes, Ciências e Humanidades da Universidade de São Paulo para obtenção do título de Mestre em Filosofia do Programa de Pós-graduação em Estudos Culturais.

Versão corrigida contendo as alterações solicitadas pela comissão julgadora em 15 de outubro de 2014. A versão original encontra-se em acervo reservado na Biblioteca $d a$ EACH/USP e na Biblioteca Digital de Teses e Dissertações da USP (BDTD), de acordo com a Resolução CoPGr 6018, de 13 de outubro de 2011.

Área de concentração: Cultura, saúde e educação.

Orientadora: $\operatorname{Prof}^{\mathrm{a}} \mathrm{Dr}^{\mathrm{a}}$ Verónica Marcela Guridi 
Autorizo a reprodução e divulgação total ou parcial deste trabalho, por qualquer meio convencional ou eletrônico, para fins de estudo e pesquisa, desde que citada a fonte.

CATALOGAÇÃO -NA-PUBLICAÇÃO

(Universidade de São Paulo. Escola de Artes, Ciências e Humanidades. Biblioteca)

Matos, Marcia Ferreira

A cultura surda nos cursos de licenciatura : práticas e perspectivas no ensino da Língua Brasileira de Sinais / Marcia Ferreira Matos ; orientadora, Verónica Marcela Guridi. - São Paulo, 2014 $200 \mathrm{f}$.

Dissertação (Mestrado em Filosofia) - Programa de PósGraduação em Estudos Culturais, Escola de Artes, Ciências e Humanidades, Universidade de São Paulo, em 2014

Versão corrigida

1. Educação especial. 2. Surdo. 3. Língua Brasileira de Sinais - Ensino. 4. Ensino superior. 5. Licenciatura. I. Guridi, Verónica Marcela, orient. II. Título.

CDD 22.ed. - 371.912 
Nome: MATOS, Marcia Ferreira

Título: A cultura surda nos cursos de licenciatura: práticas e perspectivas no ensino da Língua Brasileira de Sinais.

Dissertação apresentada à Escola de Artes, Ciências e Humanidades da Universidade de São Paulo para obtenção do título de Mestre em Filosofia do Programa de Pós-Graduação em Estudos Culturais.

Versão corrigida contendo as alterações solicitadas pela comissão julgadora em 15 de outubro de 2014. A versão original encontra-se em acervo reservado na Biblioteca da EACH/USP e na Biblioteca Digital de Teses e Dissertações da USP (BDTD), de acordo com a Resolução CoPGr 6018, de 13 de outubro de 2011.

Aprovada em 15 de outubro de 2014

\section{Banca Examinadora}

Profa. Dra Verónica Marcela Guridi

Escola de Artes, Ciências e Humanidades - EACH

Universidade de São Paulo - USP

Profa. Dra Ana Claudia Balieiro Lodi

Faculdade de Filosofia, Ciências e Letras de Ribeirão Preto - FFCLRP

Universidade de São Paulo - USP

Profa. Dra Valéria Cazetta

Escola de Artes, Ciências e Humanidades - EACH

Universidade de São Paulo - USP 
À minha mãe Georgina, pelo carinho e apoio em todos os momentos da minha vida. 


\section{AGRADECIMENTOS}

Aos professores, amigos e alunos surdos, do passado e do presente, por me apresentarem a Língua Brasileira de Sinais, as comunidades e culturas surdas.

À minha orientadora $\operatorname{Prof}^{\mathrm{a}} \operatorname{Dr}^{\mathrm{a}}$ Verónica Marcela Guridi por ter acreditado em meu projeto desde o início, pelas orientações e estímulo ao desenvolvimento de minha autonomia no processo reflexivo e investigatório.

Aos docentes da disciplina Libras que gentilmente aceitaram compartilhar suas experiências para realização desta pesquisa.

Às docentes Ana Claudia Balieiro Lodi e Valéria Cazetta pelas contribuições oferecidas na qualificação e na banca de defesa.

À docente Luciana Maria Viviani pelas sugestões na qualificação e nos encontros do grupo de estudos sobre Foucault.

Aos docentes da pós-graduação da EACH, em especial, ao Luiz Silveira Menna Barreto, à Angela Maria M. de L. Hutchison, à Soraia Ansara e à Ana Laura Godinho Lima pelas devolutivas de alguns textos que produzi, favorecendo a construção do embasamento teórico deste trabalho.

Aos meus colegas de mestrado pelas trocas, apoio e companheirismo em diversos momentos acadêmicos.

Aos meus amigos por dividirem comigo um bem tão precioso, o tempo. 
Nós surdos somos... ... cultura. Deixamos à margem o princípio universal e colocamos a enfatização de nossa cultura como necessária à nossa sobrevivência. É nosso princípio, a nossa nostalgia mais imensa e obstinada: a qualidade de vida, de comunicação, da diferença, que nos considerem sujeitos culturais e não nos considerem deficientes.

Gladis Perlin 


\section{RESUMO}

MATOS, Marcia Ferreira. A cultura surda nos cursos de licenciatura: práticas e perspectivas no ensino da Língua Brasileira de Sinais. 2014. 200 f. Dissertação (Mestrado em Filosofia) - Escola de Artes, Ciências e Humanidades, Universidade de São Paulo, São Paulo, 2014.

A presente pesquisa teve como objetivo verificar a contribuição da disciplina Língua Brasileira de Sinais (Libras) nos cursos superiores de licenciatura para circulação do discurso da diferença linguística e cultural das comunidades surdas. A área da surdez encontra-se circunscrita nas relações de poder e saber presentes na sociedade, nessa área observa-se a predominância de dois conjuntos de enunciados. Um deles se relaciona ao discurso da deficiência que tem como princípio a normalidade baseada nas pessoas ouvintes. O outro diz respeito ao discurso pautado na diferença linguística e cultural, cuja normalidade baseia-se nas pessoas surdas e no que circula e se produz em suas comunidades. Vinculada a esse último discurso, a Libras se tornou pauta de reivindicações dos movimentos políticos das comunidades surdas brasileiras, tem sido considerada a primeira língua nas propostas de educação bilíngue para surdos e foi reconhecida pela Lei no 10.436/2002, cuja regulamentação se deu por meio do Decreto Federal no 5.626/2005. Esse Decreto instituiu, dentre outras medidas, a obrigatoriamente da disciplina Libras nos cursos superiores de licenciatura e fonoaudiologia. Considerando essa normatividade, especificamente, nos cursos de licenciatura, este trabalho configura-se como uma pesquisa qualitativa que contou com a aplicação de um questionário estruturado com perguntas abertas e com a análise documental dos planos de ensino da disciplina Libras de seis docentes que ministram essa disciplina em Instituições de Ensino Superior (IES) na cidade de São Paulo e região metropolitana. Por meio da análise das regularidades presentes nos enunciados dos docentes e nos dados dos planos de ensino, verificou-se que os docentes, enquanto sujeitos do discurso, afirmam um vínculo formativo e profissional com os surdos e a Libras e, em suas práticas pedagógicas, estabelecem normatividades nos objetivos, conteúdos, estratégias e exercícios que se fundamentam no discurso que se filia, predominantemente, à diferença linguística e cultural dos surdos. Esses mesmos docentes também afirmam que a receptividade da disciplina é positiva pela maioria dos discentes e alguns destes se tornam disseminadores das práticas discursivas das aulas.

Palavras-chave: Língua Brasileira de Sinais. Cultura surda. Cursos de Licenciatura. Docente de Libras. Discurso. 


\begin{abstract}
MATOS, Marcia Ferreira. The deaf culture in undergraduate education programs: practices and perspectives in the teaching of Brazilian Sign Language. 2014. $200 \mathrm{f}$. Dissertation (Master's degree in Philosophy) - Escola de Artes, Ciências e Humanidades, Universidade de São Paulo, São Paulo, 2014.

The aim of this dissertation is to investigate the contribution of Brazilian Sign Language (Libras) classes in undergraduate education programs in order to circulate the discourse of linguistic and cultural difference of deaf communities. The field of deafness is surrounded by the relationship between power and knowledge widespread in society, this area elucidates the predominance of two sets of statements. One of them relates to the discourse of disability which has the principle of normality based on hearing people. The other concerns the discourse grounded in linguistic and cultural difference whose normalities relies on deaf people and about what circulates and is produced in their communities. Associated to this speech, Libras became the agenda of political movements from the Brazilian deaf communities and it has been considered the first language in the proposed bilingual deaf education and has been recognized by the Law No. 10.436/2002, whose regulation occurred by the Federal Decree No. 5.626/2005. This Decree established, among other measures, Libras as a mandatory class in the undergraduate courses of education programs and phonoaudiology. Considering this regulation, mostly in undergraduate education programs, this dissertation materializes itself as a qualitative research that included the application of a structured questionnaire with open questions and with a documentary analysis of Libras teaching plan of six teachers who lecture this class in Undergraduate Schools and Colleges in the city of São Paulo and metropolitan region. Throughout the analysis of the regularities present in the statements of teachers and teaching plan data, it was found that teachers, as subjects of discourse, state a formative and professional bond with deaf people and Libras. Furthermore, they establish normativities in the objectives, contents, strategies and exercises in their pedagogical practices, which are based on the discourse that mainly connect deaf's linguistic and cultural differences. These same teachers also declare that the receptivity of the program is positive for most students, whose some has become disseminators of discourse analysis from classes.
\end{abstract}

Keywords: Brazilian Sign Language. Deaf culture. Undergraduate Education Programs. Libras Teaching. Discourse. 


\section{LISTA DE ABREVIATURAS E SIGLAS}

AASI Aparelho de Amplificação Sonora Individual

AEE Atendimento Educacional Especializado

ASL American Sign Language

BSL British Sign Language

CCCS Centre for Contemporary Cultural Studies

CODA Children of Deaf Adults

EAD Educação à Distância

ELS Escrita em Língua de Sinais

Emebs Escola Municipal de Educação Bilíngue para Surdos

EMEE Escola Municipal de Educação Especial

Feneis Federação Nacional de Educação e Integração de Surdos

IC Implante Coclear

IES Instituição de Ensino Superior

L1 Primeira Língua

L2 Segunda Língua

Libras Língua Brasileira de Sinais

LGP Língua Gestual Portuguesa

LSB Língua de Sinais Brasileira

LSF Langue des Signes Française

MEC Ministério da Educação

Nuppes Núcleo de Pesquisa em Políticas Educacionais para Surdos

PCN Parâmetros Curriculares Nacionais

PNEE Política Nacional de Educação Especial

Prolibras Programa Nacional para a Certificação de Proficiência no Uso e Ensino da Língua Brasileira de Sinais - Libras e para a Certificação de Proficiência em Tradução e Interpretação da Libras/Língua Portuguesa

Tils Tradutor e Intérprete de Língua de Sinais

UFRGS Universidade Federal do Rio Grande do Sul 
UFSC Universidade Federal de Santa Catarina

WEA Workers Educational Association 


\section{SUMÁRIO}

1 INTRODUÇÃ

2 A CULTURA SURDA NO CONTEXTO DOS ESTUDOS CULTURAIS ...... 22

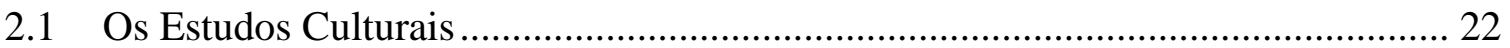

2.2 Os surdos nos enunciados vinculados à deficiência e à diversidade....................... 30

2.3 Estudos Surdos: rompendo com a tradição deficiente, vislumbrando o ser surdo

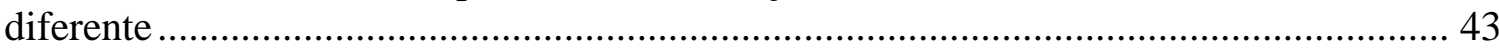

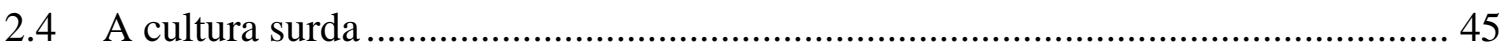

3 COMUNIDADES SURDAS: CONSTRUÇÕES IDENTITÁRIAS E

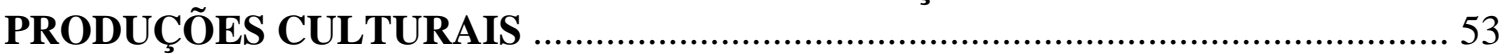

3.1 As identidades sociais e individuais dos membros das comunidades surdas ......... 53

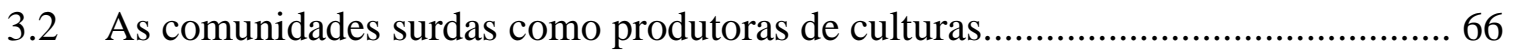

3.2.1 Produções culturais das comunidades surdas ............................................. 71

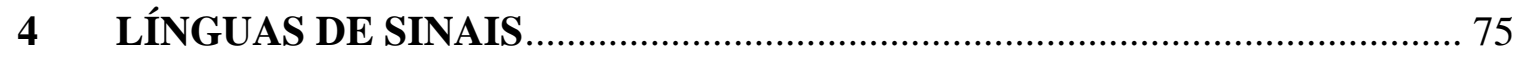

4.1 Línguas de Sinais: resistência surda no campo educacional ................................. 75

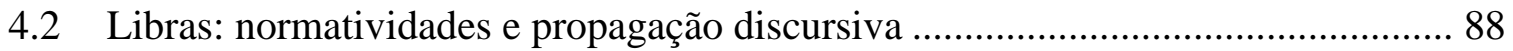

4.3 A ampliação de práticas que contemplam o uso da língua de sinais com surdos e

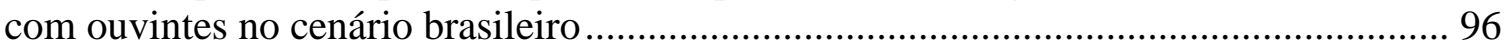

4.3.1 Os surdos e a língua de sinais: aquisição e ensino .......................................... 97

4.3.2 Os ouvintes e as demandas de aprendizado da Libras ....................................104

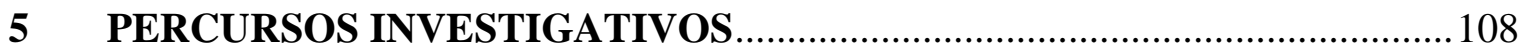

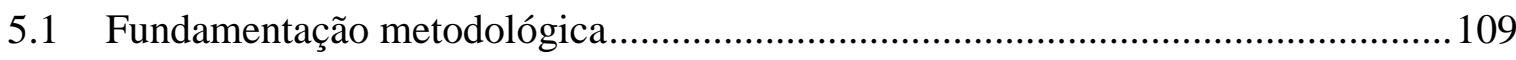

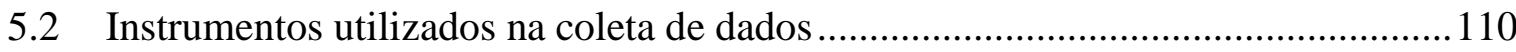

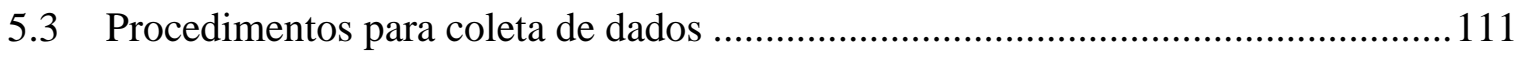

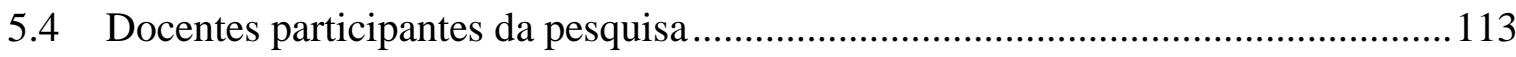




\section{A CULTURA SURDA NOS CURSOS DE LICENCIATURA: PRÁTICAS}

E PERSPECTIVAS NO ENSINO DA LÍNGUA BRASILEIRA DE SINAIS ...........114

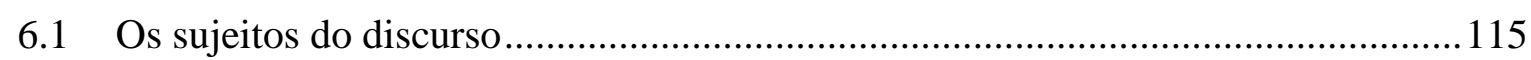

6.2 A institucionalização da disciplina Libras nas IES ............................................ 126

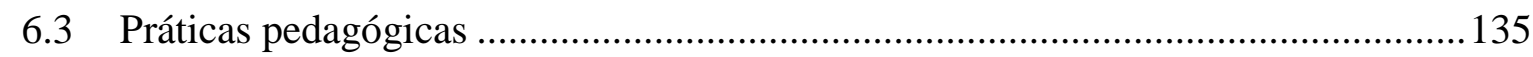

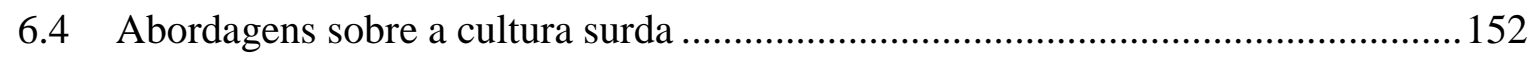

6.5 A permeabilidade dos discursos docentes ......................................................... 157

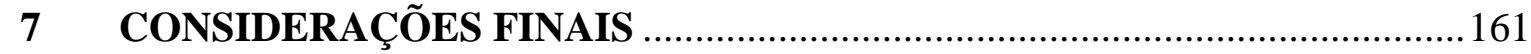

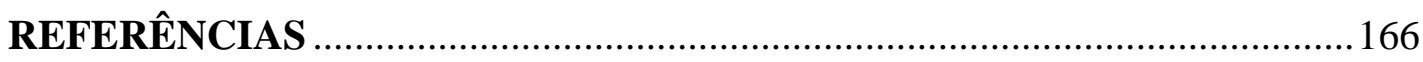

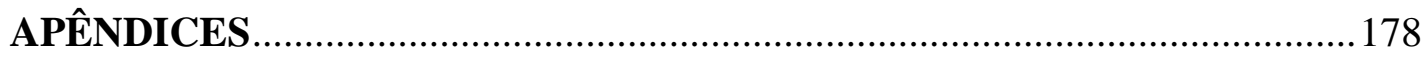




\section{INTRODUÇÃO}

...Se você ouvinte me representa, leve os meus ensejos E as minhas solicitações como eu almejo...

Shirley Vilhalva

A idealização da presente pesquisa está diretamente relacionada à minha trajetória pessoal e profissional no "mundo dos surdos". Apesar de não ser uma trajetória extensa, ela tem se configurado em um momento basilar no que concerne ao avanço das reivindicações dos movimentos políticos das comunidades surdas brasileiras; a ampliação de práticas discursivas que se apoiam na diferença cultural dessas comunidades; e a emergência de normatividades de reconhecimento e difusão da língua de sinais, especialmente, na área educacional.

Nesse sentido, na contextualização inicial desta pesquisa focarei na descrição de três experiências pessoais que contribuíram para a escolha do meu objeto de investigação. Tais experiências foram: os primeiros contatos que tive com a Língua Brasileira de Sinais (Libras); a atuação como professora de surdos e a realidade na qual meus alunos estavam - estão inseridos; e por último, a docência na disciplina Libras em cursos de Licenciatura.

Começo minha narrativa no início da adolescência, na cidade de São Paulo, ao me recordar de duas colegas de escola que tinham irmãos surdos. Mesmo que eu nunca tivesse conversado com eles sabia que se faziam entender utilizando as mãos, só não sabia que aquela comunicação poderia ser uma língua!

Alguns anos depois, no início de 2000, fui aprovada no curso de Pedagogia em uma Instituição de Ensino Superior (IES) pública localizada em Marília, uma cidade do interior do Estado de São Paulo. Escolhi essa IES porque era a única do Estado que ainda oferecia diversas opções de formação, em habilitações específicas, no próprio curso de graduação, inclusive, as habilitações voltadas para área da educação especial. E, logo no primeiro ano de graduação, me senti curiosa e motivada pelas diferentes formas de expressão comunicativa e decidi que escolheria a "habilitação em deficiência auditiva".

Nesse mesmo ano comecei as leituras informais sobre a área da surdez e a Libras. Mas, os contatos iniciais com os surdos e sua língua ocorreram somente a partir do ano seguinte, 2001, quando ingressei em um curso de Libras básico ministrado por um professor surdo e por sua esposa ouvinte que era Tradutora e Intérprete de Língua de Sinais (Tils). 
O curso ocorria em uma Igreja Evangélica e se dividia como básico I, II e III, com uma carga de 30 horas em cada módulo/semestre. O material utilizado era uma apostila organizada por campos semânticos, cujos sinais eram ilustrados e a tradução em Língua Portuguesa escrita aparecia abaixo dos mesmos.

As aulas eram sempre marcadas pela seguinte dinâmica: o professor fazia um sinal, de acordo com a ordem em que apareciam na apostila, a intérprete oralizava em Língua Portuguesa uma palavra "correspondente" e em seguida todos os alunos copiavam o sinal realizado, e assim o processo se repetia.

A cada sinal realizado, o professor acompanhava com o olhar cada aluno, e quando percebia que algum de nós estava com dificuldade, retomava o sinal detalhando-o de acordo com os parâmetros que fazem parte do nível querológico da Libras. Porém, sem mencionar essa denominação ou se apoiar em termos como "configuração de mão", "ponto de articulação" ou "orientação". Os únicos termos claramente proferidos na explicação do sinal era "movimento" e "expressão facial".

Nesse sentido, a compreensão específica sobre a forma adequada de realização de um determinado sinal ocorria quando a intérprete, por exemplo, dizia: "esse sinal é feito com a letra ' $F$ ' e não com a letra ' $T$ ' "; ou, "esse sinal deve ser feito sobre a mão e não sobre o braço"; ou ainda, "nesse sinal vocês precisam virar a mão para a frente e não para o rosto". A intérprete também esclarecia os diferentes contextos, significados ou variantes atribuídos a determinados sinais.

Os exercícios, com teor avaliativo, contemplavam a realização de um sinal pelo professor e sem consulta a apostila cada um dos alunos deveria dizer em Língua Portuguesa que sinal era aquele. No módulo II havia algumas atividades com o uso de classificadores, em que deveríamos descrever uma pessoa ou situação. Já no módulo III a proposta era selecionar e estudar em casa uma música e no dia marcado para avaliação apresentá-la em Libras para uma "banca" de surdos convidados.

Como as aulas não primavam, necessariamente, pela interação comunicativa dirigida ou espontânea, acabei aprendendo mais o léxico da Libras. O uso e o desenvolvimento da língua de sinais, em diferentes contextos e situações dialógicas, ocorreram somente por meio do encontro com interlocutores surdos nas ruas ou no terminal de ônibus, este era o local da cidade onde eles se reuniam. Sempre serei grata pela receptividade e pela paciência que os surdos tiveram quando eu ainda mal sabia dizer “Oi, tudo bem?”, em Libras.

Poucos meses antes da concluir a graduação, assumi as aulas de uma sala de recursos para surdos em outra cidade do interior. Nessa sala tive a oportunidade de prestar atendimento 
pedagógico especializado e entrar em contato com uma realidade um pouco difícil para os surdos que ali moravam.

A cidade, com aproximadamente 25 mil habitantes, tinha uma população de surdos que não havia se constituído enquanto comunidade e não tinha contato com as produções culturais de seus pares, pois os mesmos estavam reclusos dentro de suas casas ou moravam em regiões rurais distantes, inclusive, em assentamentos do Movimento Sem Terra (MST).

O desenvolvimento linguístico das crianças, adolescentes e adultos que frequentavam a sala de recursos era muito básico, e os que usavam a Libras, a havia adquirido por meio do convívio com as professoras das salas de recursos e do contato comunicativo com os colegas que frequentavam a sala no mesmo horário. Ou seja, o encontro surdo-surdo e a organização inicial do que poderia se constituir como uma comunidade surda ocorria durante algumas horas e em alguns dias da semana no interior da escola. Esta foi uma experiência prática que me permitiu conhecer de perto a realidade que só havia lido em textos que descreviam a história dos surdos no Brasil e no mundo.

Naquele momento, minha atuação estava localizada no contexto das políticas educacionais inclusivas e pude observar as dificuldades para efetivação das normatividades dessa política na prática. Todos os meus alunos que cursavam o Ensino Fundamental I, II ou o Ensino Médio, estavam incluídos em salas regulares de escolas diferentes, não tinham Tils, e se tornaram exímios "copistas". Para completar a situação, o desconhecimento dos professores e demais funcionários das escolas sobre a proposta de educação bilíngue para surdos era generalizado e a maioria demonstrava resistência ao processo de implementação da educação inclusiva no município.

O trabalho ali desenvolvido precisou ultrapassar os limites das salas de recursos e ser divulgado, sempre que possível, aos demais profissionais da educação e aos alunos ouvintes e videntes das escolas regulares em que os alunos surdos e os alunos cegos ou com baixa-visão das duas salas de recursos da cidade, estavam matriculados. Essa divulgação e o compartilhamento de informações e experiências ocorriam sempre por meio de atividades culturais protagonizadas pelos alunos das duas salas de recursos e das orientações de todas as professoras das mesmas, aos profissionais das escolas regulares.

Quando retornei para São Paulo iniciei as atividades em uma sala de recursos em uma cidade da região metropolitana. Apesar do curto período de atuação nessa sala, as atividades desempenhadas e o contato com os surdos foram valiosos.

Era o começo do atendimento pedagógico especializado aos alunos que estavam incluídos na rede pública de ensino da cidade. A distância entre esta e a cidade de São Paulo 
era de apenas $30 \mathrm{~km}$, no entanto, a realidade ali presente se aproximava muito da cidade que trabalhei anteriormente e que estava há a cerca de $600 \mathrm{~km}$ da capital.

Os alunos que tinham algum domínio comunicativo da Libras a havia desenvolvido por meio das visitas de pessoas de uma instituição religiosa que divulgava a língua de sinais na região. $\mathrm{Ou}$, como alguns alunos surdos estudaram durante vários anos na APAE (apesar de não ser voltada para surdos, a APAE era o único local que prestava atendimento educacional especializado na cidade antes da abertura das salas de recursos), houve o contato surdo-surdo permitindo a interação e a comunicação, mesmo que de forma básica e pelo uso de "sinais emergentes".

Com a abertura da sala de recursos, os alunos surdos que estavam apenas na APAE foram incluídos nas escolas regulares e começaram a frequentar o atendimento ofertado nessa sala. E de forma semelhante ao que havia ocorrido na outra cidade, o espaço se tornou o local que poderia contribuir para constituição da comunidade surda na cidade.

Em 2008, comecei a atuar em uma Escola Municipal de Ensino Fundamental da cidade de São Paulo. Como no processo de escolha de vaga não havia nenhuma nas denominadas Escolas Municipais de Educação Especial (EMEE), hoje Escolas Municipais de Educação Bilíngue para Surdos (Emebs), fui para uma escola que tinha alunos surdos incluídos e que estava distante das seis Emebs.

Mesmo que a escola escolhida fizesse parte da rede de ensino de uma cidade dotada dos maiores recursos orçamentários, materiais e humanos do país, naquele momento, a situação dos surdos que ali estavam, era muito semelhante à situação já citada nas experiências anteriores. Como eram crianças, estes alunos não frequentavam os vários pontos de encontro da comunidade surda paulistana, na escola os profissionais também tinham poucos conhecimentos acerca da educação de surdos e uma das professoras nem sequer sabia, no mês de setembro, que tinha uma aluna surda incluída em sua turma, achava que essa aluna tinha apenas alguma dificuldade de fala.

Após um semestre fui para uma Emebs e desde então atuo nela. A experiência em curso, sem dúvida nenhuma, tem sido bem diferente das experiências anteriores, pois nessa escola em todos os momentos propicia-se o desenvolvimento comunicativo em Libras e o contato surdo-surdo ocorre da Educação Infantil ao Ensino Fundamental II, e alguns alunos adolescentes e a maioria dos adultos da Educação de Jovens e Adultos (EJA) são frequentadores dos pontos de encontro da comunidade surda da cidade. Além disso, o desenvolvimento cognitivo e acesso às diferentes áreas do conhecimento ocorrem de forma semelhante ao das crianças ouvintes que estão em escolas regulares, a única diferença é que a 
língua de instrução de todas as disciplinas é a Libras, e a Língua Portuguesa é ensinada como segunda língua na modalidade escrita.

Além da atuação como professora de surdos em salas de recursos ou em Emebs, trabalhei - e ainda trabalho - como Tils voluntária ou freelancer, e ministrei vários cursos básicos de Libras, após a aprovação nos exames de proficiência em Libras promovidos pelo Ministério da Educação (MEC), o Prolibras.

Quanto aos cursos de Libras que ministrei, estes eram promovidos por instituições privadas, associações, diretorias estaduais ou secretarias municipais de ensino, nas cidades em que atuei como professora de surdos ou em cidades vizinhas. Como na maioria das situações, praticamente, inexistiam surdos com o desenvolvimento linguístico avançado e formação para o ensino da Libras, sempre que possível, convidava os alunos surdos adolescentes/adultos que frequentavam as salas de recursos para que percebessem o nicho de atuação profissional que poderiam se inserir e para que soubessem que muitos ouvintes da cidade estavam interessados em aprender essa língua.

Ampliando minha atuação no ensino da língua de sinais, além de ser professora de surdos, há cinco anos me tornei a responsável pela docência da disciplina Libras nos cursos de Artes Visuais, Educação Física, Letras, História e Pedagogia, em uma IES privada na cidade de São Paulo, na qual ainda atuo.

Paralelamente à atuação profissional, a amizade com vários surdos foi fundamental para que aprofundasse meus conhecimentos e respeitasse cada vez mais a língua de sinais, as comunidades e culturas surdas.

Assim, ao assumir um papel pessoal e profissional que transita entre surdos e ouvintes considero oportuna e necessária a observação dos processos de resistências que circulam quando o assunto é a comunicação, em diferentes ambientes da sociedade, para com aqueles que não atendem a uma determinada normalidade construída.

As experiências como professora de surdos e o fato de ter presenciado diversas situações desfavoráveis ao desenvolvimento desse público, contribuíram para que, nesse momento, me debruçasse sobre um processo reflexivo que tende para a defesa das reivindicações das comunidades surdas. E, a oportunidade de ministrar a disciplina Libras em uma IES, se constitui como um terreno profícuo para divulgar o "mundo dos surdos" e desconstruir ou problematizar alguns saberes que se apoiam na normalidade ouvinte.

A docência na disciplina tem suscitado a preocupação em estabelecer uma prática pedagógica que contribua para o processo de formação de futuros professores que podem ter em suas classes alunos semelhantes àqueles que, outrora, tive nas salas de recursos, ou 
àqueles que tenho, na Emebs. E, acima de tudo, uma prática que contemple saberes que estejam em consonância com os discursos oriundos das comunidades surdas em termos linguísticos, identitários, culturais, educacionais, sociais e políticos.

Como na IES onde trabalho, durante quatro anos, fui a única docente de Libras dos cursos de licenciatura, me sentia submetida, inicialmente, aos "olhares" que evidenciavam um misto de curiosidade, estranhamento, resistência, solidariedade, piedade, medo ou aceitação, diante das práticas discursivas que empreendia - e empreendo - nas aulas. E, esses "olhares" me influenciaram a levantar a seguinte questão: Quais seriam as práticas discursivas estabelecidas por outros docentes de Libras nos cursos licenciatura?

Esse questionamento me fez perceber o quão desafiador tem sido a docência da Libras no Ensino Superior, especialmente, nos cursos de licenciatura, na medida em que é um campo de atuação profissional recente e que carece de pesquisas e possibilidades de trocas com as práticas desenvolvidas por outros docentes da disciplina em outras IES.

Encarei esse desafio como motivação para meu ingresso no programa de pósgraduação em Estudos Culturais, especificamente, na linha de pesquisa intitulada Cultura, Saúde e Educação, para desenvolver esta pesquisa.

Nesse sentido, "A cultura surda nos cursos de licenciatura: práticas e perspectivas no ensino da Língua Brasileira de Sinais" é o resultado de um processo investigatório desenvolvido que teve como base os seguintes questionamentos: Como tem se configurado a inclusão da disciplina Libras nas IES? Quais são os perfis dos docentes que a ministram? Quais são as práticas discursivas empreendidas por esses docentes? Quais são os objetivos e conteúdos estabelecidos? Como a disciplina tem sido recebida pelos discentes dos cursos de licenciatura? A disciplina tem se apoiado nas questões linguísticas, culturais e identitárias das comunidades surdas?

Para responder alguns desses questionamentos parto do princípio que o processo que envolve a docência da Libras demanda análises que ultrapassam o domínio comunicativo e englobam, principalmente, questões de cunho cultural, identitário e educacional, em um contexto no qual a disciplina "se define por um domínio de objetos, um conjunto de métodos, um corpus de preposições consideradas verdadeiras, um jogo de regras e de definições, de técnicas e de instrumentos" (FOUCAULT, 2010, p. 30), que são capazes de por em circulação, afirmar, construir, desconstruir ou refutar conjuntos de enunciados.

Dessa forma, a Libras, pode ser localizada nas relações de poder e saber circunscritas na área da surdez. Essa área, tradicionalmente, se constituiu tendo como parâmetro a objetivação do surdo em práticas discursivas que se pautaram na normalidade ouvinte. No 
entanto, os processos de resistência das comunidades surdas permitiram a emergência de práticas discursivas e não discursivas que remetem à normalidade surda.

Atualmente, ambas as práticas encontram-se num momento de tensão, no qual está em jogo a vontade de verdade que permeiam o discurso da deficiência, filiado ao contexto clínico da surdez e aos processos de "adaptação" do surdo à sociedade ouvinte, e ao que denomino como discurso da diferença linguística e cultural, filiado as reivindicações dos movimentos das comunidades surdas, principalmente, no que tange à aceitação social dos surdos como eles são.

Tomando como premissa que o reconhecimento, a difusão e os processos de aquisição ou de aprendizagem da Libras se vinculam a esse último discurso, o docente da disciplina Libras, em um ambiente institucionalizado, tem a oportunidade de se tornar o sujeito desse discurso ao contemplá-lo na prática pedagógica desenvolvida em sala de aula. Ou seja, esses docentes podem ser os responsáveis, não apenas pela disseminação de saberes que permitam aos discentes entrarem em contato com uma língua de modalidade visual-motora, mas também os saberes que afirmam os traços e produções culturais, as construções identitárias, e as propostas educacionais, na perspectiva bilíngue, dos membros de uma comunidade minoritária que durante muitos anos esteve à margem da sociedade.

Assim, o objetivo principal deste trabalho consiste em: Verificar a contribuição da disciplina Libras nos cursos superiores de licenciatura para circulação do discurso da diferença linguística e cultural das comunidades surdas.

Para alcançar esse objetivo geral tentei construir uma fundamentação teórica calcada em três princípios: a cultura surda, enquanto construção discursiva; as comunidades surdas, enquanto locais simbólicos que favorecem as formações identitárias e permitem compartilhamentos e produções culturais; e a língua de sinais, enquanto principal traço cultural e representante dos processos de resistência dos surdos.

Nesse sentido, cultura, comunidade e língua se tornam categorias que corroboram com a emergência e disseminação do discurso da diferença, e este entra em jogo nas relações de poder e saber ao lado do tradicional discurso da deficiência que se apoia nos aspectos clínicos da surdez e na normalidade ouvinte.

O empreendimento reflexivo dessa fundamentação teórica conta, principalmente, com autores da área dos Estudos Culturais, dos Estudos Surdos, e com algumas obras de Michel Foucault que tratam do discurso e das relações de poder e saber. E, de forma complementar, 
me respaldo com a presença de diversos enunciados que podem apontar para as regularidades nos discursos em questão.

No que tange a investigação, propriamente dita, dentro dos preceitos da pesquisa qualitativa descrita por Bogdan e Biklen (1994), apliquei um questionário estruturado com perguntas abertas e fiz a análise documental dos planos de ensino da disciplina Libras de seis docentes que a ministram em cursos de licenciatura de IES, na cidade de São Paulo e região metropolitana, afim de: Levantar os perfis dos docentes da disciplina enquanto sujeitos do discurso; Levantar e analisar os dados referentes ao processo de institucionalização da disciplina Libras nas IES; Identificar os principais enunciados que têm circulado em torno da disciplina Libras, por meio dos sujeitos do discurso envolvidos e dos planos de ensino das IES, no que se refere aos objetivos, aos conteúdos e as possíveis estratégias adotadas; Relacionar os perfis dos sujeitos do discurso, a institucionalização da Libras e os enunciados que permeiam a disciplina, delineando as relações que podem contribuir para circulação do discurso da diferença linguística e cultural das comunidades surdas nos cursos superiores de licenciatura.

No que concerne à organização da fundamentação teórica, no capítulo "A cultura surda no contexto dos Estudos Culturais”, como o próprio anuncia, contextualizo a cultura surda como uma temática a ser desenvolvida no campo dos Estudos Culturais. Como este é um campo interdisciplinar, aproveitei o ensejo para também me apoiar em alguns preceitos difundidos por Michel Foucault, sobre discurso e relações de poder e saber. Promovendo uma reflexão em que a cultura surda é compreendida como uma construção discursiva. Essa construção tem se fortalecido por meio da emergência do discurso que vislumbra o surdo no contexto da diferença, em contraposição ao discurso canônico que objetiva esse sujeito numa perspectiva que atende, predominantemente, a normalidade ouvinte.

$\mathrm{Na}$ sequência, no capítulo "Comunidades surdas: construções identitárias $e$ produções culturais" abordo as possíveis tensões e negociações que permeiam as identidades dos surdos, quando estes se constituem ou não como membros das comunidades surdas. Para tanto, me apoio no tema identidade no campo dos Estudos Culturais, nos estudos de gênero e sexualidade e nos estudos críticos pós-coloniais. E, logo após, trato de algumas produções e traços culturais oriundos dessas comunidades, de acordo com pesquisas que têm afirmado a cultura surda, especialmente, no meio acadêmico.

Já no último capítulo da fundamentação teórica "Línguas de Sinais", amparada em algumas obras de Michel Foucault e em autores da área dos Estudos Surdos, início com a exposição das fases da educação de surdos com foco na elucidação das possíveis relações de 
poder e saber envolvidas nas construções discursivas que corroboram com os processos de negação da língua de sinais como língua ou do reconhecimento da mesma. Situando-me na fase mais atual, da qual se relaciona com a trajetória pessoal e profissional que descrevi nesta introdução, discorro sobre a expansão da permeabilidade da Libras nas políticas públicas e no meio acadêmico, fato que tem apontado para a ampliação de normatividades que possibilitam que essa língua, as comunidades surdas e os traços e produções culturais dos surdos se evidenciem no contexto da sociedade majoritária.

Após o desenvolvimento da fundamentação teórica, no capítulo "Percursos investigativos" me volto para descrição dos objetivos estabelecidos, da fundamentação, instrumentos e procedimentos metodológicos adotados no processo de coleta dos dados da pesquisa.

No capítulo que leva o título desta dissertação, "A cultura surda nos cursos de licenciatura: práticas e perspectivas no ensino da Língua Brasileira de Sinais”, respaldada pela fundamentação teórica, pelo estabelecimento de categorias analíticas (BOGDAN; BIKLEN, 1994), e pela identificação de regularidades nos enunciados (FOUCAULT, 2013b) que emergiram das expressões dos docentes e das descrições presentes nos planos de ensino adotados por eles, subdividi a discussão dos dados em cinco partes.

Nas cinco seções verso, respectivamente, sobre os perfis dos docentes participantes desta pesquisa, em consonância com documentos e pesquisas que tratam da formação de docentes de Libras; discuto o processo de institucionalização da disciplina Libras nas IES pesquisadas tomando como premissa o ponto de vista dos docentes; contemplo a dimensão discursiva que permeia a prática pedagógica, de acordo com os enunciados dos docentes e dos dados dos planos de ensino; em seguida, discorro sobre como ocorre a abordagem da cultura surda nas aulas; e, finalizo com as assertivas dos docentes sobre as possibilidades ou processos de resistência em torno da permeabilidade do discurso da diferença linguística e cultural nos cursos de licenciatura entre os discentes ao longo da disciplina.

Nas "Considerações finais", sintetizo as principais regularidades dos enunciados expressos pelos docentes e que se conciliam com a fundamentação teórica, estabelecendo as relações que podem contribuir para que o discurso da diferença linguística e cultural circule nos cursos superiores de licenciatura. E, concluo compartilhando um pouco das minhas percepções e práticas pedagógicas, como docente da disciplina Libras, em conformidade com os relatos dos docentes participantes. 


\section{A CULTURA SURDA NO CONTEXTO DOS ESTUDOS CULTURAIS}

A discussão que realizarei neste capítulo diz respeito à contextualização da cultura surda no campo dos Estudos Culturais. Para tanto, iniciarei com a apresentação de alguns significados correntes para o termo cultura e discorrerei sobre como esse termo tornou-se objeto de interesse e estudo em diferentes áreas, impulsionando a institucionalização de uma área específica de pesquisa, os Estudos Culturais.

Após uma breve apresentação desta área, me baseando no discurso e nas relações de poder e saber, temas presentes nas obras de Michel Foucault, explorarei os enunciados tradicionais construídos sobre a surdez e o sujeito surdo e que estão presentes quando o assunto é a deficiência e a diversidade, e localizarei a surdez e o sujeito surdo em um conjunto de enunciados construídos, mais recentemente, e que preconizam a diferença linguística e cultural e rompem com as concepções anteriores ao valorizar a língua de sinais e a ideia de cultura surda. Tais concepções de caráter discursivo diferenciador, como serão expostas, se configuram como prerrogativas presentes nas pesquisas da área dos Estudos Surdos, cujo campo se encontra em consonância, principalmente, aos preceitos e autores da área dos Estudos Culturais.

\subsection{Os Estudos Culturais}

Ao pesquisar o significado do termo cultura se nota que vários estudiosos de áreas como a Sociologia, a Antropologia e até mesmo a Psicologia já dedicaram pesquisas em busca de uma definição mais adequada ou que se aproximasse de seus objetos de interesse. Mas originalmente, de acordo com Caldas, a palavra cultura:

[...] vem do latim - colere - e significa cultivar. Com os romanos, na antiguidade, a palavra cultura foi usada pela primeira vez no sentido de destacar a educação aprimorada de uma pessoa, seu interesse pelas artes, pela ciência, filosofia, enfim, por tudo aquilo que o homem vem produzindo ao longo de sua história. (1991, p. 11).

Williams (2007) ao analisar o significado da palavra em diferentes áreas cita que o conceito de cultura na Arqueologia e na Antropologia está relacionado à produção material, e na História e nos Estudos Culturais o termo se refere aos sistemas de significação ou simbólicos. Tais significados provocaram, inclusive, análises entre a relação e os contrastes 
presentes na produção daquilo que é material e do que é simbólico. E devido a sua complexidade, segundo o autor, o termo cultura, por vários séculos, sofreu - e ainda sofre diferentes interpretações e usos nas línguas e países presentes em todo o mundo:

O uso antropológico é comum nos grupos linguísticos alemão, escandinavo e eslavo,
mas subordina-se de maneira distinta aos sentidos de arte e de erudição ou de um
processo geral de desenvolvimento humano em italiano e francês. Entre línguas,
assim como no interior delas, o leque e a complexidade de sentidos e referências
indicam tanto a diferença de posição intelectual quanto algum obscurecimento ou
sobreposição. (WILLIAMS, 2007, p. 122).

O próprio autor contribuiu para compreensão do que seria a ideia de cultura em sua obra "Cultura e Sociedade: de Coleridge a Orwel” (2011), do original inglês "Culture and Society 1780-1950” (1958), ao partir da premissa que foi durante o período da Revolução Industrial que o conceito de cultura surgiu em seu sentido moderno. E, para sua construção argumentativa, Williams escolheu e analisou textos de vários escritores ingleses, justificando sua escolha ao partir do princípio de que, apesar da Revolução Industrial ter se espalhado por todo o mundo, as relações e as questões sociais e culturais advindas daquele momento de transição histórica foram sentidas em primeira instância na sociedade e cultura inglesa, e por isso não caberiam análises de autores de outros países.

$\mathrm{O}$ autor colocou os termos indústria, democracia, classe, arte e cultura, como palavras que surgiram ou tiveram novos significados atribuídos no inglês, como termos imprescindíveis para o estudo em questão, principalmente no que tange à elaboração de um mapa sobre as mudanças que ocorreram no final do século XVIII e metade do século XIX. Ao longo do livro ele examina não apenas as diferenças entre os significados desses termos, mas as fontes e efeitos que os mesmos tiveram na sociedade. E, é válido ressaltar que Williams coloca a cultura como a palavra mais surpreendente dentre as demais, tendo em vista que as questões que permeiam os significados de cultura "são questões diretamente produzidas pelas grandes mudanças históricas que as mudanças em indústria, em democracia e em classe, cada uma a seu modo, representam e com as quais as mudanças em arte são uma resposta intimamente relacionada" (WILLIAMS, 2011, p. 18).

Nesse sentido, o termo cultura, durante a Revolução Industrial, foi reinterpretado não apenas como uma forma de reação ao industrialismo, mas ao desenvolvimento político e social, à democracia. Além disso, era preciso levar em conta a importância do desenvolvimento histórico da ideia de cultura, já que essa se vinculava ao:

[...] reconhecimento de um corpo separado de atividades morais e intelectuais e a oferta de um tribunal de recursos humanos que compreendem os primeiros significados da palavra são acompanhados, e eles próprios transformados, pela afirmação crescente de todo um modo de vida, não apenas como uma escala de 
integridade, mas como uma maneira de interpretar toda nossa experiência comum, e nessa nova interpretação, transformá-la. (WILLIAMS, 2011, p. 20).

Williams, baseando-se em suas apreciações sobre as reações engendradas na sociedade, e implícita ou explicitamente explanadas nas produções realizadas pelos escritores da época, enfatizou a importância de se considerar o contexto das ações no registro da história da ideia de cultura como uma significativa forma de modificação geral nas condições da vida em comum, pois tais condições não podem ser compreendidas de forma estática. Concebendo, principalmente, que a palavra cultura não pode ser colocada a serviço de quaisquer diretrizes sociais e pessoais, em seu sentido moderno, a mesma precisa ser caracterizada sob o prisma de uma avaliação qualitativa e processual.

Ainda discorrendo sobre o sentido moderno da palavra cultura, Williams aponta uma síntese no livro "Palavras-chave", ao apresentar as categorias nas quais a palavra cultura pode ser aplicada:

(i) o substantivo independente e abstrato que descreve um processo de desenvolvimento intelectual, espiritual e estético, a partir do S18; (ii) o substantivo independente, quer seja de um povo, um período, um grupo ou da humanidade em geral, desde Herder e Klemm. Mas também é preciso reconhecer (iii) o substantivo independente e abstrato que descreve obras e as práticas da atividade intelectual e, particularmente, artística. Com frequência, esse parece ser hoje o sentido mais difundido: cultura é música, literatura, pintura, escultura, teatro e cinema. (WILLIAMS, 2007, p.121, grifo do autor).

Nas diferentes sociedades, o significado do que pode ser a cultura, bem como o desenvolvimento da mesma, depende muito das formas de estruturação política, econômica, educacional e de todo processo histórico que constitui a totalidade das relações e práticas sociais, e diante de tal complexidade, as análises que fazemos sobre cultura não podem estar pautadas em perspectivas idealistas e superficiais. Além de se tornar objeto de estudo em diferentes áreas do conhecimento, como citado anteriormente, o termo pode ser compreendido diante da sua amplitude também como tema, tema este que ganhou destaque nos estudos que enfatizavam uma forma de repensar a cultura na sociedade inglesa e que se afastava das teorias tradicionais, se tornando objeto, inclusive, de uma disciplina específica, os Estudos Culturais.

No entanto, Hall (2009, p.126) enfatiza que mesmo no interior dessa nova disciplina o conceito de cultura continua complexo e "um local de interesses convergentes, em vez de uma ideia lógica ou conceitualmente clara. Essa 'riqueza' é uma área de contínua tensão e dificuldade no campo". Para esse autor a cultura compreende "o terreno das práticas, representações, linguagens e costumes concretos de qualquer sociedade historicamente 
específica. Também inclui as formas contraditórias do senso-comum que se enraízam e ajudam a moldar a vida popular" (HALL, 2009, p.313).

Diante das várias possibilidades do que pode ser entendido sobre a ideia de cultura verificam-se, na realidade, conjuntos de enunciados que tem se modificado ao longo da história em diferentes países e populações, e que com a inauguração de um novo campo de estudo, tem permitido que outros inúmeros enunciados sejam engendrados e propagados como saberes, de acordo, com as pesquisas, problematizações e reflexões empreendidas por vários pesquisadores que se associam aos Estudos Culturais e a outros movimentos intelectuais como descreverei, brevemente, a seguir.

Em seus primórdios, a institucionalização dos Estudos Culturais ocorreu na GrãBretanha dos anos de 1950, e algumas obras lançadas na época foram consideradas fundamentais na constituição dessa nova disciplina, são elas: a) "The Uses of Literacy" (1957) do crítico literário inglês Richard Hoggart, que estudou os impactos da cultura de massa nas tradições culturais da classe dos trabalhadores; b) "Culture and Society" (1958) do também crítico literário Raymond Williams, conforme já abordei nesse texto, que consistiu na reconstrução das reações sobre as mudanças na vida social, econômica e política na sociedade que vivenciava a Revolução Industrial, culminando no surgimento de uma nova ideia sobre o conceito de cultura; c) "The Making of the English Working Class" (1963), uma obra posterior do historiador Edward Thompson, que recuperou a história do primeiro operário inglês ao adentrar nas comunidades operárias.

Os três autores apresentam em comum, a atuação como docentes de jovens e adultos trabalhadores na Workers Educational Association (WEA). Inclusive Williams considerou essa atuação como originária dos Estudos Culturais.

\begin{abstract}
A WEA procurava construir uma nova consciência social e uma nova civilização que incluísse a classe trabalhadora como um todo. Parte importante dessa iniciativa era pensar que uma nova sociedade só podia ser criada de baixo para cima, e a educação era a ocasião de troca entre intelectuais e trabalhadores, cada um educando o outro, na medida em que os professores tinham de se esforçar para explicar disciplinas em termos que fossem entendidos por pessoas comuns e pudessem ser utilizado em movimentos reais. (CEVASCO, 2008, p.62).
\end{abstract}

Dentro das suas especificidades, cada um desses autores contribuiu para a criação de um novo tipo de estudo, estudo este que pode ser definido em quatro principais conjuntos de significados:

Como um campo interdisciplinar; como uma intervenção política nas disciplinas acadêmicas existentes; como uma disciplina inteiramente nova, definida em termos de um assunto inteiramente novo; e como uma nova disciplina, definida em termos de um novo paradigma teórico. Sem dúvida, outras definições disponíveis 
permanecem em jogo, mas essas quatro parecem especialmente proeminentes. (MILNER, 2007, p.421, grifo do autor).

Em 1964, Richard Hoggart fundou o Centre for Contemporary Cultural Studies (CCCS) na Universidade de Birmingham e, como crítico literário, defendeu que as artes populares também fizessem parte dos estudos de literatura. A sucessão do legado de Hoggart no CCCS foi realizada por Stuart Hall, em 1968, e foi a partir desse período que os Estudos Culturais se consolidaram, e demonstrando um caráter de trabalho intelectual mais político, se distanciando do reducionismo e vinculando-se à teoria cultural das relações sociais e simbólicas.

Inicialmente, o CCCS teve como cerne a formação do intelectual orgânico, já que o projeto dos Estudos Culturais estava pautado no desenvolvimento superior desse tipo de intelectual com relação ao intelectual tradicional, além do papel fundamental de disseminação do conhecimento para aqueles que não faziam parte da classe dos intelectuais. Já nos anos 1970, no CCCS, os Estudos Culturais abarcavam estudos dos mais diversos temas, porém dentre os trabalhos realizados, aconteceram duas interrupções marcantes: a entrada do feminismo e as questões de raça como objetos de estudo.

O contato com o campo do estruturalismo, da semiótica e do pós-estruturalismo, também desarticulou e favoreceu avanços importantes nas teorias elaboradas no CCCS. O avanço da globalização e das questões pós-modernas e pós-coloniais contribuiu para inserção da identidade, ou das múltiplas identidades como outro foco de interesse. Hall (1997) ao analisar os impactos da revolução cultural do final do século XX nas sociedades globalizadas, considera que experimentamos a centralidade da cultura como constituinte da subjetividade, da identidade e da pessoa como ator social.

As temáticas relacionadas à cultura também fizeram - e fazem - parte das pesquisas na América Latina e no Brasil, algumas foram desenvolvidas sem influência dos domínios do campo dos Estudos Culturais britânico, e da expansão que esse campo teve em outros países, principalmente, os Estados Unidos da América (EUA). Os Estudos Culturais começaram antes de sua institucionalização em centros e departamentos independentes, inclusive, sendo seu princípio atribuído também à diferentes autores em várias partes do mundo, “os estudos culturais tiveram uma diversidade de trajetórias: muitos seguiram e seguem percursos distintos no seu interior; foram construídos por um número de contenção uns com os outros” (HALL, 2009, p.189). 
Dentre os estudos realizados se torna comum a dificuldade de delimitar as fronteiras do que pode ou não ser compreendido como parte dos Estudos Culturais na América Latina. Ríos (2002) traça uma analogia entre os Estudos Culturais e os Estudos Culturais Latinoamericanos, ao colocar que ambos estão preocupados com a produção do objeto de pesquisa no próprio processo de investigação, e que por se tratar de um campo interdisciplinar, é capaz de quebrar e ultrapassar as fronteiras acadêmicas tradicionais, ao focar em análises culturais e políticas, que demandam reflexões críticas e autocríticas, por parte dos pesquisadores, durante a investigação e a escrita.

Cevasco (2008) aponta algumas obras que influenciaram as reflexões de intelectuais associados ao socialismo independente e a uma esquerda marxista não dogmática, bem antes da institucionalização dos Estudos Culturais no Brasil. De acordo com a autora, tais intelectuais estavam comprometidos com análises e críticas sobre a história e cultura da sociedade brasileira embasados nas obras: "Casa-grande e senzala” (1933), de Gilberto Freyre; "Raízes do Brasil" (1936), de Sérgio Buarque de Holanda; e "Formação do Brasil contemporâneo" (1942), de Caio Prado Júnior. Os três livros se caracterizavam, respectivamente, nas relações inter-raciais, na cultura brasileira sob uma ótica progressista e na escrita pautada no marxismo sobre o período colonial brasileiro.

No Brasil, a partir da chegada dos portugueses e do movimento de colonização, iniciou-se um processo dinâmico de criação, desenvolvimento e transformação de uma cultura ou várias culturas, desencadeado pela influência da pluralidade de etnias, raças e até mesmo línguas aqui presentes. E mesmo que as diferentes regiões de todo território nacional estejam dentro de uma mesma proposta política, econômica e educacional, a diversidade na constituição e organização do "povo" brasileiro, tornou a cultura, ou melhor, as culturas aqui existentes, singulares às demais presentes no mundo. Diante dessa realidade, na maioria das vezes velada, nosso país deveria ser reconhecido dentro de uma perspectiva multicultural e multilíngue.

Multicultural porque agregamos as culturas indígenas, europeia e africana, e a partir do século XX, as culturas dos imigrantes de diferentes países. Além disso, como define Hall, o termo multicultural:

Descreve as características sociais e os problemas de governabilidade apresentados por qualquer sociedade na qual diferentes comunidades culturais convivem e tentam construir uma vida em comum, ao mesmo tempo em que retêm algo de sua identidade "original". (2009, p.50). 
E, multilíngue, porque no Brasil, existem mais de 200 línguas utilizadas em todo o território. Entretanto, Quadros (2005) chama a atenção sobre o fato de termos a Língua Portuguesa como primeira língua e ignorarmos as demais línguas. Assim, as línguas indígenas, as línguas dos imigrantes e a língua dos surdos, se tornam invisíveis aos olhos da Nação, aparentemente, monolíngue.

Dessa forma, o país se subdivide na predominância de uma cultura majoritária que, na maioria das vezes, tem o poder de influenciar ou até mesmo colonizar as outras culturas, e por várias culturas consideradas como minoritárias, marginalizadas ou subculturas, que são formadas por diferentes grupos sociais como, por exemplo, os indígenas, os negros, os imigrantes e os surdos. Essas culturas minoritárias compartilham costumes, ideias, crenças e/ou línguas, em consonância com as comunidades das quais fazem parte, e acabam desenvolvendo mecanismos de resistência para preservação de suas peculiaridades perante as tentativas de imposições da cultura majoritária, no interior das relações de poder.

Dentre as culturas dos grupos sociais minoritários brasileiros, meu enfoque será nas culturas das comunidades surdas ${ }^{1}$. No entanto, na presente pesquisa convencionarei a utilização da terminologia cultura surda no singular, mesmo que esteja plenamente ciente que esta cultura não se constitui como uma unidade homogênea de um único modo de vida de todos os surdos brasileiros. Os surdos moram em diferentes lugares do território nacional e observa-se que seus contatos e experiências não são vivenciados apenas com outras pessoas surdas, mas também por meio de contatos e experiências vinculadas ao modo de vida de toda a população surda e/ou ouvinte de uma determinada comunidade/região/cidade/Estado do Brasil.

Assim, quando utilizo a terminologia cultura surda, não a emprego sob um caráter reducionista, ao contrário, minha intenção é utilizá-la de forma ampla e que abarque as diferenças culturais dos surdos brasileiros. Tendo como princípio que, nesta pesquisa, não tratarei pormenorizadamente das diferenças culturais intrínsecas aos diversos grupos de pessoas surdas, mas sim da ideia geral de cultura surda construída discursivamente e que tem ganhado status de verdade nos últimos anos.

\footnotetext{
${ }^{1}$ Dentro de uma perspectiva mais abrangente o termo comunidade, de acordo com Williams (2007), pode ser usado tanto para a descrição de um conjunto existente de relações quanto um conjunto alternativo de relações. Nesse sentido, quando mencionar o termo comunidade surda, estarei me referindo a um conjunto existente de relações que se estabelecem no contato surdo-surdo e no contato surdo-ouvinte, quando se apresentam laços de identificação social, em diferentes níveis, entre os envolvidos. No capítulo "Comunidades surdas: construções identitárias e produções culturais" pormenorizarei esta temática.
} 
Nesse sentido, compreendo a cultura surda como uma construção discursiva que faz parte das diferentes relações presentes na sociedade e que diz respeito a um conjunto de ideias, de costumes, de práticas sociais interativas, organizativas e comunicativas incorporadas, evidenciadas, partilhadas e produzidas pelas pessoas surdas.

E, para me aproximar dessa construção e tomá-la como um dos temas a ser desenvolvido, debatido, problematizado e colocado enquanto projeto político no campo dos Estudos Culturais, abordarei os conjuntos de enunciados produzidos sobre os surdos, e que são recorrentes no meio acadêmico, na sociedade de forma geral e nas comunidades surdas. Dando maior ênfase ao discurso que afirma a cultura surda e a coloca sob um ponto de vista distinto da cultura ouvinte, pois esse discurso pode fornecer pistas sobre as relações de poder e saber em disputa pela legitimação cultural, linguística e identitária dos sujeitos surdos.

No processo reflexivo adotado, além de me apoiar nos preceitos dos Estudos Culturais, também me embasarei nas asserções presentes nas obras de Michel Foucault. E, apesar dessa aproximação não ser uma tarefa fácil, as possibilidades se tornam mais factíveis quando se sabe que em sua trajetória Foucault teve como cerne de seus estudos, conforme ele mesmo atesta, a transformação dos seres humanos em sujeitos, ou seja, ele assumiu diferentes modos de investigação nos processos de elucidação da objetivação do sujeito, cuja averiguação demandou o uso das dimensões do poder (FOUCAULT, 2013a).

Nessa empreitada intelectual, Foucault, trilhou diferentes caminhos, alguns destes muito discutidos e criticados por outros intelectuais, outros mais aceitos e tomados como referência. Em alguns deles empregou analíticas em objetos que implicavam relações de poder e, ao mesmo tempo, permitia a compreensão dessas relações com o saber e a vontade de verdade presentes na sociedade (FOUCAULT, 2006). De forma complementar, em uma possível analogia com os Estudos Culturais, as pesquisas abertamente desenvolvidas sobre as práticas culturais nessa área, de uma forma ou de outra, acabam se vinculando as relações de poder, como atestam Nelson, Treichler e Grossberg (2009, p. 11):

Trabalhar dentro dessa configuração bastante ampla exige, naturalmente, uma análise daquelas relações de poder e o nosso lugar dentro delas. Além disso, o termo "relações" aponta para a longa história dos Estudos Culturais para teorizar e capturar as mútuas determinações e inter-relações das formas culturais e das forças históricas.

Apesar do poder não ser tematizado da mesma forma por Foucault e pelos autores da vanguarda dos Estudos Culturais, conforme foi exemplificado por Veiga-Neto, este mesmo autor coloca que as aproximações têm ocorrido em pesquisas mais recentes nessa área sob a seguinte premissa: 
Se o filósofo centrou suas descrições e análises sobre a fabricação do sujeito moderno utilizando, entre outras coisas, um entendimento peculiar acerca do poder, nada impede que se mantenha o mesmo entendimento - "aplicável" no nível microfísico, horizontal, distribuído, capilar -, mesmo quando se olha para as outras relações que se dão entre diferentes instâncias e níveis sociais. A essas outras relações - macroscópicas, verticais, centralizadas, maciças - daremos outro(s) nome(s) (violência, dominação, etc), para que fique claro que há, entre essas e o poder, uma distinção que não é apenas de intensidade ou de lugar em que atuam, mas que é, sobretudo, da própria natureza de cada uma. (VEIGA-NETO, 2000, p. 66).

Dessa forma, ao longo desse trabalho, desenvolverei uma narrativa que remeta aos discursos e as relações de poder e saber, temas presentes nas obras de Foucault, e que considero fundamentais no processo de compreensão da emergência do sujeito surdo, ao se enfatizar a surdez, nos níveis sociais e históricos, como uma característica distintiva em diferentes conjuntos de enunciados presentes na sociedade. O que me permite circular, minimamente, entre algumas das principais normatividades estabelecidas para contextualizar meu objeto principal de estudo, no caso, a cultura surda, enquanto construção discursiva, no contexto da disciplina Libras nos cursos superiores de licenciatura.

Nos tópicos que ainda compreendem esse capítulo inicial, darei atenção às construções discursivas que permeiam a constituição do sujeito surdo em diversas formas/meios de localização social.

\subsection{Os surdos nos enunciados vinculados à deficiência e à diversidade}

Apesar de ter me apropriado, no texto até então escrito, de alguns dos termos foucaultianos, antes de iniciar a discussão específica sobre o discurso que localiza os sujeitos surdos nos contextos da deficiência e da diversidade, caberia esclarecer dentro das obras de Foucault, o que tenho utilizado como discurso e, consequentemente, o enunciado para, a partir daí, adentrar na discussão proposta nesse subitem.

Foucault (2013b, p.131) menciona que o discurso "é constituído por um conjunto de sequências de signos, enquanto enunciados, isto é, enquanto lhes podemos atribuir modalidades particulares de existência", e cita que o mesmo pode ser fixado como um "conjunto de enunciados que se apoia em um mesmo sistema de formação; é assim que poderei falar do discurso clínico, do discurso econômico, do discurso da história natural, do discurso psiquiátrico". No entanto, é válido ressaltar que esta não é a única definição de discurso presente na obra do autor, ele ainda ressalta que o discurso: 
[...] não forma uma unidade retórica ou formal, indefinidamente repetível e cujo aparecimento ou utilização poderíamos assinalar (e explicar se for o caso) na história; é constituído de um número limitado de enunciados para os quais podemos definir um conjunto de condições de existência. $\mathrm{O}$ discurso, assim entendido, não é uma forma ideal e intemporal que teria, além do mais, uma história; o problema não consiste em saber como e por que ele pôde emergir e tomar corpo num determinado ponto do tempo; é, de parte a parte, histórico - fragmento de história, unidade e descontinuidade na própria história, que coloca o problema de seus próprios limites, de seus cortes, de suas transformações, dos modos específicos de sua temporalidade, e não de seu surgimento abrupto em meio às cumplicidades do tempo. (FOUCAULT, 2013b, p. 143).

$\mathrm{Na}$ área da surdez encontramos conjuntos de enunciados consolidados como unidades, especialmente, no discurso clínico. Em alguns momentos da história observamos que esse discurso serviu de suporte ou até mesmo foi incorporado, por exemplo, pelo discurso pedagógico. Ou ainda, que tal discurso clínico estabeleceu significativa influência nos enunciados presentes na sociedade, de forma geral, sobre o surdo e a língua de sinais, ou até mesmo esteve em condição de oposição aos enunciados da comunidade surda.

O discurso clínico sobre a surdez esteve presente - e ainda está - como um conjunto de enunciados, um saber "verdadeiro" e propagado em livros, artigos científicos, nas falas dos médicos, dos fonoaudiólogos, dos professores, das famílias que tem filhos surdos, dos ouvintes que não tem contato com surdos e de alguns dos próprios surdos. Esse discurso vincula-se a uma vontade de verdade que para Foucault situa-se como um sistema de exclusão apoiado sobre um suporte institucional que permite o reforço e a recondução do saber na sociedade, ou como diz o autor a vontade de verdade dessa maneira "tende a exercer sobre os outros discursos [...] uma espécie de pressão e como que um poder de coerção" (2010, p. 18).

De forma sucinta e simplista, o discurso clínico sobre a surdez centraliza-se na perda total ou parcial da capacidade ouvir, logo, o foco está na ausência, na "anormalidade" de uma parte do corpo. A partir daí buscam-se medidas para corrigir ou curar esta parte do corpo "defeituosa", essa "deficiência" chamada de surdez.

A noção de surdez vai além da perda ou redução de uma capacidade funcional de um dos sistemas do corpo, pois ela permeia e se fortalece em saberes pautado na normalidade instituída ao corpo humano, à comunicação, ao modo de vida e às trocas estabelecidas na sociedade. Assim como cita Foucault (2010, p. 20):

[...] só aparece aos nossos olhos uma verdade que seria riqueza, fecundidade, força doce e insidiosamente universal. E ignoramos, em contrapartida, a vontade de verdade, como prodigiosa maquinaria destinada a excluir todos aqueles que, ponto por ponto, em nossa história, procuraram contornar essa vontade de verdade e recolocá-la em questão contra a verdade. 
O conjunto de enunciados engendrados no interior das comunidades surdas durante muito tempo se constituíram como exemplos de uma tentativa de ir contra a verdade instituída sob o viés do discurso clínico da surdez. Tais enunciados não se centram em uma parte do corpo, mas centram-se no sujeito como um todo, que se diferencia do outro não pela normalidade corporal, mas por ser alguém cuja comunicação, o modo de vida e as trocas estabelecidas na sociedade ocorrem visualmente.

O discurso sobre a surdez, em geral, sob o viés das comunidades surdas tenta colocar em pauta uma vontade de verdade que contradiz a verdade estabelecida tradicionalmente. A vontade de verdade das comunidades surdas encontra-se centrada nas diferenças linguística, cultural, identitária, social e política e não na deficiência em si.

No entanto, esse viés das comunidades surdas, será retomado mais para frente, pois antes quero entrar em uma discussão anterior, pois para considerar os surdos como constituidores de cultura, é preciso redirecionar os olhares acerca da surdez e dos surdos, e tal redirecionamento demanda o rompimento com visões, representações e com o discurso tradicional proferido e consolidado como saberes e verdades, proeminentemente, oriundos da comunidade majoritária ouvinte.

Seguindo está linha reflexiva o discurso desenvolvido acerca do surdo e da surdez vincula-se com as relações de poder e saber estabelecidas pelos diferentes grupos sociais, pois conforme esclarece Foucault:

[...] o discurso desempenha um papel no interior de um sistema estratégico em que o poder está implicado, e para o qual o poder funciona. Portanto, o poder não é nem fonte nem origem do discurso. O poder é alguma coisa que opera através do discurso, já que o discurso é um elemento em um dispositivo estratégico de relações de poder. (2006, p.253).

O discurso sobre os surdos, ao longo de boa parte da história, esteve pautado na deficiência e, contemporaneamente, além da deficiência, dentre outras possibilidades, também pode ser localizado no contexto da diversidade, esses são termos que se ramificam discursivamente do saber clínico e adentram em outras esferas da sociedade, em especial, na educação e no mercado de trabalho. Para problematização, especificamente, do conjunto de enunciados que recorre à deficiência e à diversidade, explorarei as terminologias "normal", "anormal”, "surdo-mudo" e deficiente auditivo, como expressões que embutem relações de poder e saber que perpassam o "mundo dos ouvintes" e o "mundo dos surdos" e que são tratadas por alguns autores como práticas colonialistas ou, como denominado por Skliar (2005b; 2009), ouvintistas. Como bem explica o autor: 
O termo "Ouvintismo" e as suas derivações "ouvintização", "ouvintista", etc., sugerem uma forma particular e específica de colonização dos ouvintes sobre os surdos. Supõem representações, práticas de significação, dispositivos pedagógicos, etc., em que os surdos são vistos como sujeitos inferiores, primitivos e incompletos. (SKLIAR, 2009, p.7).

As pessoas surdas, principalmente as que nasceram ou adquiriram a surdez durante a infância, foram - e ainda são - encaradas e enquadradas de acordo com a perspectiva da deficiência. Tal premissa tem como foco a identificação e classificação dos sujeitos de acordo com as normas e padrões estabelecidos do que poderia ser considerado ou esperado como um corpo "normal". Ou seja, o estabelecimento da suposta "normalidade" ou "essência" humana prevê que todas as pessoas devem apresentar integridade física, biológica e cognitiva, além de comportamento social “adequado". E todos aqueles que não correspondem à média construída ou imaginada, são estigmatizados e considerados como pessoas desviantes ou "anormais".

Goffman (1988) ao abordar o tema estigma discorre sobre a possibilidade de essa condição acometer tanto as pessoas que são estigmatizadas, quanto as pessoas ditas "normais", pois ambas estão sujeitas a participarem de um ou de outro papel no decorrer da vida. E ressalta que a condição de ser "normal" ou ser estigmatizado, não se encontra nas pessoas em si, mas nas perspectivas engendradas no contato misto e no não cumprimento das normas dessas pessoas em situações sociais.

Algumas alternativas sobre os incômodos que podem ser causados pelas terminologias "normal" e "anormal” são apresentadas por Veiga-Neto (2001). Segundo ele uma das alternativas pode se vincular à negação abstrata daqueles que são considerados "anormais" e as consequentes ações de exclusão dos mesmos. Outra alternativa recorre ao uso de figuras de retórica, das quais os eufemismos, ou frases politicamente corretas, camuflam práticas e discursos para com os chamados "anormais". A naturalização da relação "normal" e “anormal” também é considerada pelo autor como uma alternativa que se liga à anterior, pois apesar da possibilidade de discussões favoráveis de cunho político e de inclusão social aos ditos "anormais", essa anormalidade também se encontra reduzida a questões técnicas. Por último, o autor aborda a alternativa da problematização das questões que envolvem os "normais" e "anormais", bem como a exposição das mesmas tendo como parâmetro a submissão dessas questões à hipercrítica. No entanto, o autor alerta que:

No plano conceitual e teórico isso envolve riscos e exige cuidadosas análises acerca da genealogia não propriamente do grupo "anormais", mas de cada um dos muitos tipos que a Modernidade agrupou sob essa denominação. No plano prático, a situação é tão mais difícil e perigosa quando se trata de pensar, propor e implementar políticas sociais que levem em consideração que, afinal, os anormais estão aí e muito tem de ser feito por e junto com eles. (VEIGA-NETO, 2001, p. 108). 
Os surdos, no contexto da deficiência passam a ser considerados, como pessoas "anormais", como um desvio da normalidade baseada na pessoa que ouve - o ouvinte. Como alguém que apresenta um estigma - a surdez. Como um deficiente, pois algo lhe falta perante o corpo normal - a audição. Esta ganha outra dimensão e interpretação por aqueles que são considerados "normais", já que algumas pessoas ampliam a identificada e classificada incapacidade de ouvir, como algo que também acomete todo o corpo desviante, pois se propaga que a surdez além de inviabilizar a fala, prejudica o desenvolvimento cognitivo, a estabilidade emocional e o comportamento social.

Diante desses saberes, algumas narrativas incorporam expressões como "surdo-mudo" e deficiente auditivo ${ }^{2}$, sem querer adentrar em outras mais pejorativas como, "mudinho”. Esta é uma expressão generalizada usada por muitos ouvintes para identificar o surdo de uma determinada região/bairro quando seus vizinhos, por exemplo, não conhecem o nome dele.

Apesar da expressão "surdo-mudo" ser considerada antiga e inadequada, ainda continua presente nas falas de muitas pessoas ouvintes, e de alguns poucos surdos, que circulam em diferentes ambientes sociais e apresentam nível socioeconômico ou acadêmico diverso.

O termo "surdo-mudo" se tornou uma verdade vinculada a um saber construído, e que pode ser desconstruído quando se tensiona a instituição da normalidade biológica e sociocomunicativa do ser humano, como características amalgamadas nos enunciados proferidos pela sociedade como veremos na descrição que se segue.

A normalidade biológica e sociocomunicativa estabelece que todos os seres humanos são dotados da capacidade auditiva e que esta capacidade se relaciona à aquisição e desenvolvimento da fala oral, e se estende aos aspectos sociais e emocionais como podemos observar na clássica citação abaixo:

\footnotetext{
A audição é o meio pelo qual o indivíduo entra em contato com o mundo sonoro e com as estruturas da língua que possibilitam o desenvolvimento de um código estruturado, próprio da espécie humana. A língua oral é o principal meio de comunicação entre os seres humanos, e a audição participa efetivamente nos processos de aprendizagem de conceitos básicos, até a leitura e a escrita. Além disso, influi decisivamente nas relações interpessoais, que permitirão um adequado desenvolvimento social e emocional. (SANTOS; LIMA; ROSSI, 2003, p.17, grifo meu).
}

\footnotetext{
${ }^{2}$ Utilizarei o termo "deficiente auditivo" não, necessariamente, como utilizado por autores que classificam a surdez em tipos e graus, mas sim como um termo que se vincula às discussões sobre a instituição de uma normalidade corporal e identitária.
} 
O surdo, ao ser enquadrado dentro dos preceitos dessa normalidade, é encarado como uma pessoa que ao apresentar déficit auditivo, isto é, uma "deficiência auditiva", tomando como base os trechos da descrição de Santos, Lima e Rossi (2003), implicitamente, também passa a ser considerado como um "deficiente da língua(gem)", um "deficiente da fala ('mudo')", um "deficiente intelectual" e um "deficiente nas relações sociais e no equilíbrio emocional".

A pessoa surda, de acordo com esse ponto de vista, apresenta uma condição com o chamado "efeito dominó"; pois, aquele que era apenas surdo, se torna "mudo", com propensão à incapacidade cognitiva, social e emocional. E esse efeito só pode ser minimizado ou afastado com a implementação de normatividades para o desenvolvimento da língua de modalidade oral-auditiva, algumas dessas normatividades são citadas por Silva e Araújo (2007, p. 253, grifo meu):

O distúrbio auditivo na infância pode provocar efeitos diversos na comunicação e uma série de deficiências secundárias, como: alterações perceptuais, de fala, de comunicação, cognitivas, emocionais, sociais, educacionais e intelectuais. Os aparelhos de amplificação sonora podem ser um recurso no tratamento da perda auditiva de diversos graus, porém pacientes com discriminação menor que $40 \%$ em teste de reconhecimento de sentenças em apresentação aberta, são candidatos a uma segunda alternativa de reabilitação: o implante coclear (IC).

Rezende (2012, p. 21) enuncia a experiência, por ela vivida, dentro da perspectiva que toma como princípio a aquisição de línguas de modalidade oral-auditiva:

\begin{abstract}
Aos dois anos de idade, fui levada para a clínica especializada [...]. Era um espaço em que o uso da língua de sinais era terminantemente proibido. Isso obrigava a mim e às outras crianças surdas a fazerem uso da fala e da leitura labial. Éramos escravas sem nossas mãos. Éramos aprisionadas sem a possibilidade de expressar os nossos sentimentos e pensamentos através delas. Passei nove anos sujeita a uma concepção de linguagem que entende a língua como um aglomerado de sílabas. Era obrigada a aprender a falar "ma-me-mi-mo-mu" repetidamente, em uma espécie de inferno fonoaudiólogico. Meu único alívio era conviver com meus colegas surdos, pares iguais a mim, e isso me deixava muito alegre.
\end{abstract}

Em seu enunciado fica evidente o incômodo e a insatisfação com a forma pela qual ela era tratada durante a infância, e o caráter reducionista e artificial do processo de aquisição e desenvolvimento de uma língua na modalidade oral-auditiva. Porém, ao mesmo tempo em que a autora traz aspectos de como se sentia sob as estratégias utilizadas dentro de uma determinada prática discursiva: "passei nove anos sujeita a uma concepção de linguagem que entende a língua como um aglomerado de sílabas. Era obrigada a aprender a falar "ma-me-mimo-mu" repetidamente"; ela aponta para a afirmação de outro discurso: "éramos aprisionadas 
sem a possibilidade de expressar os nossos sentimentos e pensamentos através delas [no caso, suas mãos]", ou ainda "meu único alívio era conviver com meus colegas surdos".

Apesar de existirem muitos surdos que relatam experiências semelhantes à de Rezende (2012), existem outros que não consideram o processo de desenvolvimento da fala oral da mesma maneira como, por exemplo, relata Sinedino ${ }^{3}$, um surdo oralizado:

\begin{abstract}
Se eu me sentia diferente em relação aos surdos sinalizados? Eu sempre me senti como ouvinte, talvez por fazer parte do mundo dos ouvintes. Em casa, todos eram ouvintes, todos meus amigos de infância eram ouvintes. No meu colégio, só havia ouvintes. Portanto, era mais do que normal, eu me sentir como uma pessoa normal. A surdez era apenas um mero detalhe em minha personalidade assim como um míope carrega a miopia como um mero detalhe. Na minha fono, tinham crianças surdas e eu não me sentia no mundo delas. Não é preconceito e nem nada, era apenas uma criança vendo que aquela tribo não era dela. (SINEDINO, 2009, grifo meu).
\end{abstract}

Nesse relato, percebe-se como alguns surdos proferem o discurso que preza pela normalidade baseada no uso da oralidade. Pois, Sinedino (2009), diz que seu convívio entre os ouvintes o permitia se sentir "normal" e o "estranhamento" se dava quando encontrava com surdos que usavam a língua de sinais.

Popularmente, as pessoas ouvintes, de forma geral, ao observar os surdos "gesticulando" sem utilizar a fala oral, pressupõem que se trata de pessoas que além de não escutar (generalizando, como se todos eles não escutassem nada), também não falam, já que ao se aproximarem dos surdos, os ouvintes afirmam não ter escutado nenhuma palavra, mas apenas alguns sons "estranhos". Ou quando são surdos oralizados, ao não "perceberem" a surdez, pensam que são pessoas estrangeiras ou com algum "problema” na fala.

Os surdos, geralmente, acessam o mundo sonoro com restrição, mas podem falar línguas de modalidade oral-auditiva, mesmo que estas requeiram um processo artificial de desenvolvimento, baseado em uso de Aparelho de Amplificação Sonora Individual (AASI) ou Implantes Cocleares (IC), alguns ou vários anos frequentando terapia fonoaudiológica, dentre outras normatividades amplamente divulgadas em estudos focados na reabilitação da surdez.

Já as pessoas denominadas como “mudas", por não terem perda auditiva, podem acessar as línguas oral-auditivas, no entanto, apresentam dificuldades para expressão oral, mas isto não significa, necessariamente, que elas desenvolvam naturalmente línguas de modalidade visual-motora, apesar de poderem utilizar a comunicação não-verbal.

\footnotetext{
${ }^{3}$ O texto completo da entrevista de Sinedino (2009) encontra-se em: <http://desculpenaoouvi.laklobato.com/2009/05/06/falaraul/> Acesso em: 07 jun. 2014.
} 
Os enunciados que denotam o conhecimento considerado como senso-comum, quando disseminados fortalecem a estigmatização dos surdos, sejam eles usuários das línguas de sinais ou das línguas orais, conforme aponta Lobato, que se tornou surda aos 10 anos de idade:

[...] por conta dos dois únicos estereótipos que a maioria esmagadora de pessoas conhece, deficientes auditivos ou são surdos sinalizados ou são idosos com baixa audição, comumente ironizados em programas de comédia. E, como eu não era nenhum dos dois, toda hora eu tinha [...] que contar a minha história para justificar por A + Z porque eu não correspondia aos estereótipos. (LOBATO, 2009) ${ }^{4}$.

Rezende (2012), com outro teor, compartilha sua experiência exemplificando a descrença em seu próprio potencial perante a pessoa ouvinte:

\begin{abstract}
Sentia-me inferior a meus colegas ouvintes, assim como um "Patinho Feio" no meio de tantos cisnes. Na época da formatura do ensino médio, bradei a meio mundo que nunca mais voltaria a estudar, mas muito de minha história ainda estava por vir. Decidi que tentaria o acesso à universidade e fui aprovada no vestibular de Pedagogia na primeira tentativa, para a surpresa de muitos. Era um misto de medo e de alegria. Medo, porque eu sabia que tinha que brigar pelos próximos quatro anos no espaço universitário. Alegria, porque havia conquistado um espaço disputado. Eu tinha em meu íntimo que seria incapaz de ser alguém na vida. Já havia me acomodado como deficiente.
\end{abstract}

Além dos aspectos abordados, questões que se referem à normalidade sociocomunicativa pairam sobre teorias de desenvolvimento de língua e linguagem. Tais teorias apesar de considerarem a importância da interação social para o desenvolvimento de competências linguísticas partem de pressupostos baseados na capacidade auditiva para compreensão dos sons/fonemas, e da fala oral produzida pelos órgãos responsáveis pela fonoarticulação para expressão de línguas orais.

Pouco se aborda ou se aprofunda na comunicação não verbal, como parte das habilidades comunicativas presentes entre as pessoas, sejam elas ouvintes ou surdas, e, praticamente, esquece-se do desenvolvimento de estruturas linguísticas complexas de línguas de modalidade visual-motora. Pois, de forma diferente das línguas oral-auditivas, as línguas visual-motoras se desenvolvem com a compreensão visual de sinais manuais que se expressam pela articulação e movimento das mãos em um espaço determinado, complementados com expressões faciais e corporais. Fernandes (2003, p. 44) afirma que:

Observamos na língua de sinais as várias acepções de uso, as expressões idiomáticas, metafóricas/figurativas, os aspectos estilísticos, as contextualizações que admitem a pressuposição e o implícito, enfim, as mesmas características de

\footnotetext{
${ }^{4} \mathrm{O}$ texto de Lobato (2009) encontra-se na introdução do relato de Sinedino (2009) em: <http://desculpenaoouvi.laklobato.com/2009/05/06/falaraul/ > Acesso em: 07 jun. 2014.
} 
qualquer língua natural, quer em seu aspecto gramatical, propriamente dito, quer nas várias manifestações do simbólico.

Assim, uma possibilidade de desconstrução da ideia do "surdo-mudo" pode ser resumida sob duas premissas principais. A primeira é a que considera o fato de existirem surdos usuários das línguas orais como primeira língua (L1) e que poucas pessoas apresentam surdez e mudez $z^{5}$ pois, na maioria das vezes, ou são surdas ou “mudas”. E a segunda é a que considera a existência de línguas de modalidade visual-motora que foram desenvolvidas por meio do contato surdo-surdo, independentemente, da normalidade biológica e sociocomunicativa estabelecida.

Não obstante, ressalto que não são apenas os surdos os esquecidos quando as pessoas falam sobre a normalidade sociocomunicativa baseada em línguas oral-auditivas. As pessoas que apresentam mobilidade corporal reduzida, cujo acometimento também pode ser nos órgãos responsáveis pela fonoarticulação dos sons, como por exemplo, as pessoas com paralisia cerebral, assim como os surdos, acabam sendo estigmatizadas.

Em sua maioria, as pessoas com paralisia cerebral não apresenta restrições no processo de desenvolvimento cognitivo e de linguagem, apesar de uma significativa parcela da população proferir enunciados no sentido contrário. A aparente impossibilidade de comunicação pode ser desconstruída quando essas pessoas têm acesso às línguas de modalidade visual-motora e/ou o acesso às línguas de modalidade oral-auditiva, cujo apoio comunicativo pode ocorrer com o uso de sistemas de Comunicação Alternativa e/ou Suplementar como, por exemplo, o Blissymbols, Picture Communication Symbols (PCS), entre outros.

Voltando à explanação dos termos que permeiam as visões relacionadas aos surdos no que diz respeito, especificamente, ao termo deficiente auditivo, este, muitas vezes, é utilizado sob a premissa do "politicamente correto". A explicação do senso-comum ao se referir à pessoa surda, como deficiente auditiva e não "surda-muda" recai na hipótese de que esta pessoa desenvolveu a fala oral, logo, não pode ser considerada surda e "muda". Ao questionar as pessoas ouvintes sobre o uso do termo deficiente auditivo, facilmente encontram-se descrições do tipo: "O deficiente auditivo escuta um pouco!”; "O deficiente

\footnotetext{
${ }^{5}$ Cabe esclarecer que utilizo o termo "mudez" ou "mudo(a)" como uma generalização para se referir as pessoas que apresentam a afasia ou a afonia.
} 
auditivo perdeu a audição depois do nascimento!”, “O deficiente auditivo perdeu a audição em um acidente!”, “O deficiente auditivo não escuta, mas fala!”, entre outras.

Essas breves descrições demonstram que o termo deficiente auditivo também se relaciona à normalidade sociocomunicativa, sendo uma condição desviante, cuja alusão se vincula à incapacidade, ao sentimento de piedade, às práticas paternalistas e à necessidade de intervenções de "cura" ou amenização "desse mal", "dessa doença" chamada surdez, por meio de ações corretivas de cunho tecnológico, cirúrgico e reabilitador, como prerrogativas do processo de ouvintização.

Lane discorre sobre a representação imaginativa que os ouvintes fazem sobre como é ser surdo, sem conhecimentos prévios da cultura surda e da língua de sinais:

\footnotetext{
No estereótipo do ouvinte, a surdez representa a falta e não a presença de algo. $\mathrm{O}$ silêncio é sinônimo de vácuo [...] para o ouvinte, "silencioso" representa o lado obscuro do surdo. Quem é surdo não pode ter a mesma orientação e segurança no seu ambiente que nós temos no nosso; com certeza, que não podem apreciar música, dizemos a nós próprios; nem participarem numa conversa, ouvir anúncios ou utilizar telefones. A pessoa surda anda à toa, parece que está numa redoma; existe uma barreira entre nós, por isso o surdo está isolado. (LANE, 1992, p. 23).
}

O autor também cita a representação realizada pelo ouvinte quando este conhece um surdo exemplificando da seguinte forma "John compreende-me quando falo diretamente com ele; por conseguinte pode afirmar-se os surdos conseguem ler os lábios" (LANE, 1992, p. 22).

Nesse sentido, é possível afirmar que muitos enunciados acerca do "mundo dos surdos", pelos ouvintes, ocorrem na tentativa imaginativa de se colocar no lugar do outro, na observação e afirmação generalizada de características individuais e pelo acesso ao que está descrito sobre os surdos e a surdez em pesquisas, na literatura e na mídia. E todas estas construções podem enfatizar estigmas, deturpações e inadequações sobre as comunidades surdas, já que boa parte do que consta na literatura ou que é divulgado na mídia, são enunciados produzidos pela maioria ouvinte.

Thoma (2005) fez uma pesquisa com notícias veiculadas em jornais no Rio Grande do Sul nas décadas de 1970, 80 e 90, partindo da premissa que por meio da mídia se elaboram práticas e políticas que categorizam os surdos e a surdez, tendo como embasamento a constituição do imaginário social que segundo ela:

Depende essencialmente da forma como ele é difundido e, neste sentido, a força dos meios de comunicação é essencial. Mas, assim como a mídia, também as religiões, os mitos e a ideologia cumprem a função de constituir o imaginário de uma sociedade em uma determinada época. (THOMA, 2005, p. 124). 
Nessa pesquisa os títulos e conteúdos das notícias, em sua maioria, retratam o surdo do ponto de vista da deficiência e incapacidade. A autora abordou notícias que se vinculam às questões que permeiam o mundo do trabalho, cujo acesso não é ofertado em postos que requerem a formação em nível superior; a vanglória de estudantes surdos realizarem pesquisas, ou ainda, de surdos dançarem diferentes ritmos musicais; além disso, os temas das notícias também englobavam assuntos sobre os aspectos clínico-biológicos da surdez, os processos de reabilitação, os avanços tecnológicos e a educação especial destinada aos mesmos, enfatizando o processo de "cura" e de aprendizagem das línguas orais, dentro de um contexto normalizador.

Thoma (2005) enfatizou que as opiniões dos surdos raramente aparecem nas notícias e quando isto ocorreu em uma delas, o surdo defendia um ponto de vista que contemplava uma minoria da comunidade surda, pois se referia à reivindicação de projeto de lei para que houvesse a legenda em programas televisivos ao invés da presença do intérprete de língua de sinais. Ou seja, a pressuposição se fundamentava na ideia de que todos os surdos tinham bom domínio da língua da comunidade ouvinte e o acesso às informações e conteúdos televisivos deveriam ocorrer por meio da língua majoritária, não contemplando os surdos que tem como L1, a língua de sinais.

E ainda considera que as construções enunciativas expostas pela mídia:

[...] vão sendo criadas e legitimadas fazendo, por exemplo, com que a opinião pública ora se sensibilize pelos limites encontrados pelos surdos no mercado de trabalho, ora superestime considerando-o capaz de realizar todo tipo de atividade, apesar da deficiência. O que menos se percebe (ao menos por aqueles que convivem frequentemente com surdos) é que tanto em um caso como em outro, o preconceito aparece em primeiro plano, seja subestimando a capacidade do surdo, seja superestimando-a. (THOMA, 2005, p. 134, grifo da autora).

De forma não muito diferente podemos localizar os surdos no conjunto de enunciados que compreendem a diversidade e/ou a deficiência e que se encontram presentes nas falas do senso-comum, na literatura especializada e na mídia, como a pesquisa que acabei de expor e, de forma complementar, como afirma Skliar (2009, p. 12) "o discurso da deficiência mascara a questão política da diferença; nesse discurso a diferença é melhor definida como diversidade e, assim a diversidade não é outra coisa senão as variantes de uma normalidade, de um projeto hegemônico".

No entanto, a diversidade, de uma forma mais ampla também inclui em seu discurso não apenas as pessoas consideradas com deficiência auditiva, deficiência visual, deficiência intelectual, mobilidade reduzida, surdocegueira, transtorno do espectro do autismo, dislexia, entre outros, mas também aqueles originários ou descendentes de grupos étnicos, 
socioeconômicos e linguísticos minoritários ou subalternos perante a norma eurocêntrica, branca, masculina, linguística e socialmente "superior", instituída historicamente.

O discurso sobre a diversidade aponta para a minimização das desigualdades sociais, econômicas, raciais, culturais e linguísticas imbricadas no poder construído e difundido por aqueles que se consideravam o créme de la créme da sociedade, e que na atualidade se apoiam em enunciados com viés inclusivo favoráveis "aos outros" que eles mesmos excluíram outrora.

Duschatzky e Skliar (2001) circunscritos no contexto da modernidade e da pósmodernidade descrevem três formas nas quais a diversidade pode ser anunciada. A primeira forma encara "o outro como fonte de todo mal", partindo do princípio que a alteridade foi regulada e controlada por meio de diferentes estratégias e com poucas variações nas narrativas:

\begin{abstract}
Entre elas a demonização do outro: sua transformação em sujeito ausente, quer dizer, a ausência das diferenças ao pensar a cultura; a delimitação e limitação de suas perturbações; sua invenção, para que dependa das traduções oficiais; sua permanente e perversa localização do lado externo e do lado interno dos discursos e práticas institucionais estabelecidas, vigiando permanentemente as fronteiras - isto é, a ética perversa da relação inclusão/exclusão -; sua oposição a totalidades de normalidade através de uma lógica binária; sua imersão e sujeição aos estereótipos; sua fabricação e sua utilização, para assegurar e garantir as identidades fixas, centradas, homogêneas, estáveis etc. (DUSCHATZKY; SKLIAR, 2001, p. 121, grifo dos autores).
\end{abstract}

A segunda coloca "os outros como sujeitos plenos de uma marca cultural". Essa marca tende à homogeneização das pessoas e à forma como elas vivem, ou seja, não são apenas as identidades que se tornam fixas, mas também a estruturação da cultura ocorre de forma desvinculada dos processos de poder e hierarquização.

Por último os autores citam "o outro como alguém a tolerar" e consideram que:

\footnotetext{
A tolerância consagra a ruptura de toda contaminação e revalida os guetos ignorando os mecanismos através dos quais foram construídos historicamente. A tolerância não põe em questão um modelo social de exclusão; quando muito, ela trata de ampliar as regras de urbanidade com a recomendação de tolerar o que é perturbador. (DUSCHATZKY; SKLIAR, 2001, p. 136).
}

Mesmo sendo enquadrados e coagidos nos enunciados da deficiência e da diversidade, os surdos buscam romper com as ideias que concernem às terminologias "surdo-mudo" $\mathrm{e}$ deficiente auditivo, das traduções realizadas sobre eles e a fabricação de normalidades biológica e sociocomunicativa segundo o padrão ouvinte, por meio de movimentos sociais e políticos próprios que afirmam a diferença, ao se reconhecerem e se denominarem como surdos. 
Como lembra Lane (1992), para as comunidades surdas, a terminologia surdo agrega valores que perpassam as culturas, línguas de sinais e experiências partilhadas pelos e entre os seus membros. E explica:

Isto não é negar o facto de que existem crianças ouvintes e adultos com deficiências auditivas. Mas a maioria das crianças com as quais, o sistema teve bons resultados na atribuição de novo rótulo eram culturalmente surdas antes e após a nova designação. (LANE, 1992, p. 90).

Ao reivindicarem o reconhecimento das diferenças linguísticas, identitárias e culturais dos membros das comunidades surdas, como comunidades que fazem parte da sociedade, os surdos constroem outros conjuntos de enunciados que não se submetem mais ao crivo da verdade e do saber proferido pelos ouvintes, mas pelo dos próprios surdos. Nesse contexto, se inscreve o rompimento com o discurso canônico, e se instaura outro discurso, que vislumbra um projeto político do "ser" surdo enquanto diferença e não deficiência. Já que "as diferenças são sempre diferenças, não devendo ser entendidas como um estado não desejável, impróprio, de algo que cedo ou tarde voltará à normalidade” (KLEIN, 2004, p. 88).

Nesse sentido, a conscientização dos surdos como membros de uma comunidade diferente permite a articulação de movimentos de resistências frente às formas de dominação, disciplinamento ou normalização oriundas de grupos majoritários. E, quando se compreende que o poder está em toda parte, a resistência nesse caso, não se dissocia das relações de poder, pois ela pode tanto fundá-las quanto se constituir como resultado das mesmas (REVEL, 2005), e numa perspectiva complementar caso essas resistências não sejam possíveis, restarão apenas possibilidades de mecanismos de sobrevivência (SKLIAR, 2009).

As comunidades surdas ao se articularem estrategicamente, no cotidiano, frente ao discurso instituído, bem como no meio acadêmico, quando pesquisadores da área da surdez se vinculam a campos teóricos como os Estudos Surdos, demonstram movimentos de resistência. Verifica-se que ambos se afastam, problematizam e se contrapõem ao discurso da tradição normalizadora, presentes na literatura e em práticas sociais que reafirmam e prezam o "ser" ouvinte como algo superior e desejável por todos. E, no item a seguir, pormenorizarei esse processo de resistência me baseando, principalmente, em pesquisas e referências que se identificam com essa área de estudo. 
2.3 Estudos Surdos: rompendo com a tradição deficiente, vislumbrando o ser surdo diferente

No campo acadêmico, alguns pesquisadores nas últimas duas décadas têm procurado outras formas de observar, analisar, interpretar, refletir, escrever e se posicionar aos aspectos que fazem parte do "ser" surdo e das diferenças intrínsecas as comunidades e culturas surdas espalhadas pelo mundo. Tais pesquisadores têm consolidado e ampliado seus trabalhos no campo denominado Estudos Surdos.

No Brasil, inicialmente os Estudos Surdos se vincularam ao Núcleo de Pesquisa em Políticas Educacionais para Surdos (NUPPES) do programa de pós-graduação em Educação da Universidade Federal do Rio Grande do Sul (UFRGS), que tinha como propósito criar um novo espaço acadêmico onde os temas relacionados aos surdos tivessem como foco de compreensão a diferença e o reconhecimento da articulação política (SKLIAR, 2005). Mas, atualmente, os Estudos Surdos compreendem um campo de pesquisa de interesse de diversos pesquisadores da área da surdez espalhados por todo o território nacional, e de Universidades e Centros de Estudos de diferentes países.

Várias pesquisas foram realizadas e algumas obras publicadas no campo dos Estudos Surdos, algumas antes mesmo da sua institucionalização em grupos e centros de pesquisas no Brasil. Tais pesquisas foram - e continuam sendo - desenvolvidas não apenas por ouvintes envolvidos e engajados com as comunidades surdas, mas também por pesquisadores surdos, ampliando-se, assim, as possibilidades de novas representações e novos conjuntos de enunciados adentrarem tanto no "mundo dos surdos", quanto no "mundo dos ouvintes". Cito como exemplo os pesquisadores surdos e ouvintes, Perlin (2004; 2005), Strobel (2008), Skliar (2009; 2005), Quadros (2005), Thoma (2004; 2005), Lopes (2005), Sá (2002), entre vários outros.

Todos eles têm como premissa que "a distinção entre surdos e ouvintes envolve mais que uma questão de audiologia, é uma questão de significado: os conflitos e diferenças que surgem referem-se a formas de ser" (SÁ, 2002, p. 49, grifo da autora). E, fazendo uma analogia com a linha argumentativa que já desenvolvi, até então, a resistência frente à construção discursiva sobre a normalidade sociocomunicativa, certamente fundou outras relações de poder, cuja construção enunciativa se pauta em outra perspectiva. No caso, as formas de ser surdo não são identificadas, categorizadas e narradas de acordo com o discurso canônico sobre a surdez, mas ao discurso cuja diferença é percebida, inclusive, em momentos e situações bem distintas daquelas pautadas na vontade de verdade vinculada ao saber clínico. 
Tomando como exemplo a situação que ocorre com pais ouvintes diante da desconfiança de terem um filho surdo, a surdez, geralmente, é previamente percebida por esses pais no cotidiano quando a criança demonstra a ausência ou insuficiência de respostas frente aos estímulos sonoros no ambiente familiar. Em seguida, quando os pais dessa criança a submetem a exames clínicos, a mesma além de ser identificada como alguém que tem surdez, é classificada em tipos e graus de surdez. No entanto, essa identificação e classificação é um saber que ganha força de verdade para os pais e não, necessariamente, no caso em questão, para a criança surda. Esta terá uma percepção de "ser" surda, em outros momentos e situações de sua vida, como relata, por exemplo, Vilhalva, sobre quando e como se deu conta de sua diferença:

[...] descobri que era diferente das demais crianças durante uma brincadeira de paua-pique. Todas as crianças ficavam uma do lado da outra, e uma determinada pessoa gritava: "Já". Então todos corriam e batiam em um local escolhido e voltavam correndo, mas eu, para minha surpresa, fiquei parada no mesmo lugar; levei um susto. A partir daí fui percebendo que era diferente. (VILHALVA, 2012, p. 22).

Lane (1992, p.93) relata outro exemplo tendo como parâmetro uma família composta apenas por pessoas surdas cuja "anormalidade" encontra-se, dessa vez, no ouvinte:

\begin{abstract}
Um surdo vindo de uma distinta família surda conta como, enquanto criança fez amizade com uma menina da porta ao lado. Descobriu, no entanto, que não podia se comunicar com ela do mesmo modo que comunicava com sua família, mesmo os gestos mais simples a deixavam confusa. Por isso estava limitado a apontar-lhe e a trazer-lhe as coisas ou levá-las até ela. Ele não sabia o que nela havia de errado, foi então que algo aconteceu para confirmar sua convicção de que, na realidade, ela era mesmo estranha. Um dia a mãe dela veio ao seu encontro, enquanto eles estavam a brincar e começou a mover, furiosamente, a boca; subitamente a sua companheira apanhou os brinquedos e foi-se embora. $\mathrm{O}$ meu amigo foi ter com a sua mãe e perguntou-lhe o que era aquele tipo de aflição que a criança tinha. A sua mãe explicou-lhe que ela podia falar, não era surda, não sabia a linguagem gestual e por isso ela e a mãe comunicavam através da fala.
\end{abstract}

Esses dois exemplos demonstram de forma simples e clara que a percepção sobre "ser" diferente, não implica em um saber disciplinado que incidi sobre seu próprio corpo, mas de um saber construído de acordo com a relação que se tem com o outro. Nos casos de Vilhalva (2012) e do surdo narrado por Lane (1992), o outro era um ouvinte que teve uma reação adversa daquela que para eles era esperada, e que tal reação lhe serviu como um insight para que a diferença de si mesmo e a do outro, fossem identificadas.

Essa diferença foi marcada pela percepção de uma situação sociocomunicativa que envolveu a oralidade. No entanto, essa oralidade não foi relevante, já que ela não foi notada em seu caráter auditivo, mas sim visual. A surdez, para a maioria dos surdos, não lhe coloca em condição de inferioridade, pois "não se sabe" o que é ouvir, "não se sabe" que ouvir é uma 
"normalidade", e "não se sabe", tão pouco, que falar oralmente é o "normal". A diferença ou ainda, a normalidade em "ser" surdo, recai na forma de ser, estar e viver no mundo, de forma visual.

E é essa perspectiva visual que é construída discursivamente instituindo outro saber e outra vontade de verdade, por boa parte das comunidades surdas e dos pesquisadores da área dos Estudos Surdos. Nesse campo a primazia é a diferença enquanto possibilidade para se observar, analisar, discutir, contar e recontar as histórias, as culturas, as línguas, as identidades, as comunidades, as artes, as produções literárias, os projetos educacionais, enfim, as várias possibilidades de construção política e social do "ser" surdo. E sob estes princípios que os Estudos Surdos se encontram em consonância com as concepções, tensões e confrontos dos diferentes temas abarcados no campo dos Estudos Culturais.

O discurso emerge, historicamente, sob a base da diferença linguística e cultural. Ou seja, enunciados propagam saberes que atestam que o surdo se comunica por uma língua que lhe permite fazer parte do ambiente sociocomunicativo visualmente e estabelecer todo um modo de vida próprio que, sob o caráter discursivo, permite elevá-los ao status de produtores e compartilhadores de traços culturais. E será sobre essa construção discursiva com teor cultural que concluirei o presente capítulo.

\subsection{A cultura surda}

Para elucidar, brevemente, a construção discursiva que tem se tornado evidente no cenário atual quando o tema é o "ser" surdo e a constituição da sua referida cultura, na escrita que se segue, me pautarei em autores surdos e ouvintes que tiveram esse foco temático, e cujos conjuntos de enunciados se inscrevem como um saber que tem sido considerado como verdadeiro dentro das relações de poder que permeiam o objeto cultura em seu sentido mais amplo.

A cultura surda tem se tornado pauta, principalmente nas últimas duas décadas, dos enunciados que se configuram como a expressão dos movimentos de resistências das comunidades surdas e que se consolidam quando essa começa a se desvincular das práticas ouvintistas. Como já discuti anteriormente, essas tentativas têm como foco a normalidade sociocomunicativa baseada nos ouvintes sem levar em consideração a diferença em "ser" surdo. 
A cultura surda ao conquistar um lugar enunciativo nas teias das relações de poder que estão emaranhadas na ideia geral de cultura e ao ser disseminada como um saber "verdadeiro", tem provocado o fortalecimento de sua "existência" no interior das comunidades surdas, que reivindicam, primordialmente, o respeito e o reconhecimento das línguas de sinais, a efetivação de políticas educacionais bilíngues, a implementação de ações de acessibilidade comunicativa em diferentes espaços sociais e a divulgação das produções culturais dos surdos que habitam as cidades brasileiras e outros países. Esses movimentos têm gerado a ampliação do interesse por parte dos pesquisadores, educadores, representantes políticos, que não faziam - ou ainda não fazem - parte, necessariamente, das comunidades surdas, em empreender normatividades que atendam ou problematizem tais reivindicações.

Seja no plano conceitual ou nas produções culturais oriundas das comunidades surdas, na história canônica dessas comunidades no Brasil ou no mundo, nunca foi gerada uma expansão analítica tão intensa quanto o que tem se observado nos últimos anos. Conforme enfatiza Gomes (2011, p.122):

[...] saberes advindos do povo surdo sobre sua cultura vêm tomando força discursiva e adentrando em inúmeros espaços e tempos no campo da educação de surdos. A comunidade surda reivindica o reconhecimento de sua cultura; a academia procura entendê-la e analisar suas produções; os espaços educativos são conclamados a promovê-la; os gestores das políticas públicas questionam sua existência. Ou seja, estamos diante de um tema nada tranquilo, que provoca diferentes manifestações, entre as máximas da exaltação até da negação.

A cultura surda como uma forma de articulação política localizada no discurso da diferença procura romper com as representações tradicionais construídas sobre os sujeitos surdos, se opondo e/ou problematizando as concepções centradas no discurso da deficiência, do patológico, da incapacidade, da educação especial ou até mesmo sob o prisma do ridículo ou do exótico perante os ouvintes. Skliar (2005a, p. 6) aponta que:

\footnotetext{
A diferença como significação política é construída histórica e socialmente, é um processo e um produto de conflitos e movimentos sociais de resistências às assimetrias de poder e de saber, dá uma outra interpretação sobre a alteridade e sobre o significado dos outros nos discursos dominantes.
}

Boa parte dos enunciados que circulam em torno da ideia de cultura surda proclama que os surdos têm se afirmado como grupos minoritários que desenvolveram línguas de modalidade visual-motora e experiências culturais próprias vinculadas, primordialmente, ao acesso e interpretação do mundo de forma visual. Como afirma Strobel (2008), a cultura surda está relacionada com o jeito que o surdo percebe, compreende e modifica o mundo, tornando este acessível e habitável de acordo, principalmente, com suas experiências visuais. 
Porém, muitas pessoas consideram que a existência de uma cultura surda se torna um aspecto curioso, incômodo ou até mesmo pode ser uma ideia rejeitada (SKLIAR, 2005b). Esta rejeição encontra-se fundamentada na forma com que as pessoas percebem os surdos no contexto da deficiência e incapacidade e na necessidade adaptativa do surdo ao modo de vida ouvinte, sem levar em consideração o fato de que os surdos apresentam características que se sobressaem à normalidade sociocomunicativa instituída.

Santana afirma que:

\begin{abstract}
A adoção do termo "cultura surda", "identidade surda", "comunidade surda", "biculturalismo" e "multiculturalismo" expressa os conflitos e a busca por soluções. [...] cada um desses termos carrega consigo convicções e expectativas acerca do significado da surdez e, apesar de diferentes, eles podem constituir possibilidades de solução para os mais diversos dramas. (2007, p. 34).
\end{abstract}

Em outro trecho a autora enfatiza que:

\begin{abstract}
A discussão da literatura em torno da cultura surda pressupõe diferença entre surdos e ouvintes e postula uma ideia de realidade homogênea. Entretanto, essa diferença faz parte de um processo de cisão social que não é recente. O próprio discurso sobre a desigualdade também faz parte desse mesmo processo. Um processo que, em vez de aproximar os surdos dos ouvintes, distancia-os, já que enfatiza o que têm de diferente e não o que têm em comum. (SANTANA, 2007, p. 47).
\end{abstract}

A linha reflexiva adotada por Santana (2007) se distancia da que adoto nessa pesquisa, na medida em que, quando trago alguns dos enunciados que afirmam o "ser" surdo, enquanto diferença linguística e cultura, e enunciados que enfatizam a suposta normalidade sociocomunicativa de acordo com o padrão ouvinte, não pretendo instituir a separação entre surdos e ouvintes, mesmo porque, a fronteira entre um discurso e outro, não é claramente delineada, mas sim fragmentada no tempo e no espaço em que se evidenciam. Nesse sentido, concebo que todos esses enunciados fazem parte das relações de poder e saber, e que essas relações são pautadas no emprego de ações que respondem a outras ações.

Ou seja, as construções enunciativas que tomam o surdo na perspectiva da diferença e isso inclui a invenção e o uso dos termos e significados correntes sobre "comunidade surda", "identidade surda", "identidade ouvinte", "cultura surda", "cultura ouvinte", "mundo surdo", "mundo ouvinte", "Surdo" ações em resposta a outro conjunto de ações que compreende o surdo como uma pessoa deficiente. E, para compreender as relações de poder que se inscrevem os conjuntos de ações

\footnotetext{
${ }^{6} \mathrm{O}$ uso do termo Surdo com "S" maiúsculo emergiu nos processos iniciais de afirmação e marcação da diferença entre os surdos usuários das línguas de sinais e engajados nos movimentos políticos das comunidades surdas. No entanto, esse não é mais um termo tão usual e convencionou-se o uso do termo "surdo" no mesmo contexto discursivo.
} 
em questão, como sugere Foucault (2013a), é necessário averiguar não apenas as formas de resistência existentes, mas as tentativas de dissociação dessas relações.

Perlin (2004) ressalta que a cultura surda não pode ser pensada a partir de uma perspectiva unificadora, e muito menos ser observada a partir da cultura majoritária, no caso, a cultura ouvinte. A autora considera que a cultura surda deve ser observada levando-se em consideração a fragmentação presente nos grupos culturais na cultura moderna, e na tensão destes grupos perante a presença de constantes sensações de sobrevivência a partir da diferença. Em seguida, afirma que é em decorrência da prática social e das diferenças nela presente que a cultura se constitui:

[...] é o caso de ser surdo homem, de ser surdo mulher, deixando evidências de identidade, o predomínio da ordem, como, por exemplo, o jeito de usar sinais, o jeito de ensinar e de transmitir cultura, a nostalgia por algo que é dos surdos, o carinho para com os achados surdos do passado, o jeito de discutir política, a pedagogia, etc. (PERLIN, 2004, p.77).

A existência de comunidades surdas organizadas ou o estabelecimento mínimo do contato surdo-surdo influenciam na constituição dos enunciados sobre o modo de vida dos surdos. Os surdos de grandes centros urbanos como São Paulo, Rio de Janeiro, Porto Alegre, Curitiba, Florianópolis, Salvador, Recife, entre outras cidades brasileiras, podem vivenciar um cotidiano diferente dos surdos que vivem em cidades menores, em ambientes rurais, ou fazem parte ou têm contato com outras comunidades também consideradas como minoritárias, como por exemplo, as comunidades indígenas.

No entanto, verifica-se que os movimentos de resistência e militância política no processo de afirmação linguística e cultural das comunidades surdas ocorrem, principalmente, por meio da organização de líderes e pesquisadores surdos que são oriundos de grandes centros urbanos, e que muitas vezes, já ocuparam cargos em associações ou federações voltadas para esse público. Ou seja, os enunciados que afirmam e disseminam a "existência" da cultura surda no Brasil aparecem de forma constante entre esses líderes e pesquisadores, e aos poucos vão sendo incorporados pelos demais surdos e alguns ouvintes que fazem parte e/ou participam das comunidades surdas.

Gomes (2011) realizou uma pesquisa sobre os enunciados de surdos pesquisadores pioneiros no tema cultura surda no Brasil e de surdos líderes nas comunidades surdas, e sua análise fornece alguns indícios sobre o que tem sido construído em torno da afirmação da "existência" da cultura surda.

Gomes aponta que os surdos da pesquisa tratam a cultura surda de diferentes formas e descreve que nos enunciados o tema aparece como um "DNA cultural surdo", quando a 
cultura surda é colocada como parte da vida dos surdos, como algo próprio deles desde que nasceram.

Apoiando-se na etimologia da palavra religião, a autora discorre que a cultura surda pode ser compreendida como uma forma de ligação com algo que estava perdido e justifica: "uso essa estratégia descritiva no sentido de anunciar a cultura surda em sua forma salvacionista, de reencontro com sua essência surda. [...] o contato surdo-surdo é o que acende, toca, induz essa ligação cultural, que faz o 'religare' com sua essência" (GOMES, 2011, p. 128).

A experiência visual também é citada como uma característica intrínseca à cultura surda, e por permitir ao surdo o acesso e a interpretação do mundo, conforme aponta a autora, ela foi considerada como algo "patenteado" pelos surdos.

Outra possibilidade abordada consiste em "ver a cultura surda como 'ser ou estar'[...] para o surdo, a cultura surda significa a condição de 'ser', ao passo que, para ouvintes, indica a condição de "estar"” (GOMES, 2011, p. 128). Nessa prerrogativa a cultura surda se torna "natural" ao surdo, no entanto, para os ouvintes, esta pode ser acessada, mas nunca lhe será "natural".

Sobre essa consideração, ressalto o fato de a cultura, no que diz respeito ao contato, experiência, troca e produção, por se caracterizar enquanto um fenômeno social, por ambos os grupos, não pode ser acessada de forma "natural". Mas, pode ser percebida como um fenômeno experimentado ou compartilhado de diferentes maneiras tanto entre os surdos quanto entre os ouvintes.

De forma complementar a autora ainda cita "a cultura surda como as muralhas do mundo surdo", e este mundo pode ser acessado por filhos ouvintes de pais surdos, por ouvintes casados com surdos e pelos intérpretes. No entanto, conforme aponta Gomes (2011), o acesso a este mundo pode ser tanto concedido, quanto negado, tudo dependerá da postura que estes ouvintes terão nas comunidades e no acesso as produções culturais dos surdos.

Assumindo um caráter libertador a cultura surda, enquanto objeto de luta da comunidade surda, é abordada pela autora quando discorre sobre a associação do movimento surdo aos movimentos das feministas e dos negros.

A cultura surda também é citada como algo que corre o perigo de "extinção" fundamentada na hibridização cultural "entre surdos ou ouvintes, e, se a racionalidade cultural está calcada nos encontros para a 'purificação' da espécie e 'vigilância' dos indesejáveis visitantes ouvintes, a globalização pode ser significada como ameaça constante" (GOMES, 2011, p. 129). 
Por último, a cultura surda também é proferida como sinônimo de língua, já que a língua de sinais é considerada como uma das grandes marcas culturais da comunidade surda.

Diante do que foi exposto verifica-se que a categorização atribuída por Gomes (2011) para compreender os enunciados sobre a cultura surda reflete processos de afirmação, resistência e luta em torno da diferença do que pode ser o "ser" surdo detentor, produtor e disseminador de sua própria cultura, e o quanto a cultura ouvinte ainda se configura uma ameaça à cultura surda, apesar desta estar conquistando, aos poucos, espaço na sociedade.

Diferentemente de Gomes (2011), que focou sua pesquisa nos enunciados oriundos dos próprios surdos, Silva (2012) deu preferência aos enunciados advindos dos agentes religiosos - estes apresentam uma longa tradição histórica em termos de proximidade com as pessoas surdas ${ }^{7}$ no mundo e no Brasil - bem como com os intelectuais e ativistas políticos. Porém, o autor esclarece que essas categorias são tomadas apenas como posições sociais, pois a mesma pessoa pode ocupar os diferentes postos.

$\mathrm{Na}$ pesquisa foram considerados os agentes que estão vinculados às seguintes instituições: a Igreja Católica, a Igreja Evangélica Luterana do Brasil, a Igreja Batista da Convenção Batista Brasileira e a Testemunhas de Jeová. Ao longo de sua produção textual o autor tenta demonstrar como os agentes/instituições e suas produções materiais (dicionários, apostilas e outras publicações), mediaram a emergência discursiva da surdez no contexto étnico-linguístico.

$\mathrm{O}$ autor sintetiza essa questão ao afirmar que os agentes participantes da pesquisa apontam que em decorrência do surdo ter uma língua própria e apresentarem perda auditiva, eles teriam uma cultura e "o que fundamenta tal crença é um senso prático presente entre os agentes que faz da língua e cultura categorias que se implicam e estabelecem equivalências" (SILVA, 2012, p. 30).

Ainda de forma complementar, ao se apoiar em autores da área da antropologia menciona que:

\begin{abstract}
A utilização da categoria cultura pelos agentes em questão está a serviço de um argumento étnico. Assim, toda e qualquer diferença percebida e produzida entre pessoas que em relações específicas se definem como surdas e ouvintes são indicializadas, em um jogo de espelhos, às categorias cultura surda e cultura ouvinte. Tal como na produção de gênero e étnica, opera-se uma supressão de semelhanças [...], de modo que diferenças percebidas de maneira situacional, política e contrastiva, [...] compõem o argumento dos agentes sobre essas culturas particulares. (SILVA, 2012, p. 30 grifo do autor).
\end{abstract}

\footnotetext{
${ }^{7}$ No capítulo "Língua de Sinais" essa aproximação histórica será abordada.
} 
No meio educacional descrevo os resultados de uma breve pesquisa que realizei (MATOS, 2012) tendo como público-alvo professores surdos e ouvintes que ministraram aulas para alunos surdos em escolas bilíngues para surdos e em escolas regulares, e que expuseram o que compreendiam sobre a ideia de cultura surda. Boa parte das construções enunciativas dos professores teve como cerne a relação entre a cultura surda e a língua de sinais, a cultura surda e a comunidade surda, e a cultura surda e as produções culturais que se relacionam aos surdos. Abaixo cito três exemplos dessas relações proferidas pelos professores:

\footnotetext{
Acho que cultura surda é o jeito que o surdo pensa, se expressa, como ele se comunica. A gente vê que é diferente quando se faz uma frase em língua portuguesa e a mesma frase em língua de sinais, então essa língua de sinais também faz com que ele tenha um pensamento diferente, um modo de agir diferente [...] a expressão facial, a expressão corporal, tudo que tá [está] na língua. Língua e cultura não tem como você separar! [...].

O significado de cultura são os costumes e regras de um grupo, por exemplo: índios, orientais e os surdos [...].

[...] são histórias referentes à cultura surda, são as piadas que eles têm como próprias então, às vezes piadas de ouvintes não tem graça, mas as que eles criam dentro da cultura deles são engraçadas [...]. (MATOS, 2012, p. 2942).
}

Outros enunciados sobre a cultura surda podem ser identificados na escrita de Perlin (2004) que aponta algumas mudanças na vida dos surdos, conforme ela mesma denomina, em uma espécie de virada cultural. Ao exemplificar tais mudanças, ela chama a atenção para a presença e atuação de surdos na docência e pesquisa, da língua de sinais como objeto de ensino, da defesa pelo emprego da pedagogia surda na educação, a maneira de viver das famílias surdas, a maior independência das mulheres surdas, além dos equipamentos tecnológicos com recursos visuais que facilitam a acessibilidade comunicativa e relacional dos surdos. E de forma complementar considera que:

\begin{abstract}
Em algumas cidades, raros lugares estão fora do alcance da cultura surda, inclusive o estereótipo e o preconceito estão perdendo terreno. Veem-se novos jeitos de ser surdo, com seu modo de comprar, olhar, comunicar, escolher, socializar. Existe, inclusive, uma curiosa nostalgia de desejo cultural, de opção pelos locais de cultura surda, como Paris, na França, e seus museus históricos que guardam preciosas referências sobre antepassados surdos; Gallaudet como universidade dos surdos; Porto Alegre como campo de lutas surdas sobre educação e Direitos Humanos. (PERLIN, 2004, p. 78).
\end{abstract}

A autora ainda aponta as mudanças subjetivas que ocorrem com os surdos ao terem contato com sua cultura e se identificarem como surdos, independentemente, do grau de surdez, pois este assume caráter insignificante na comunicação utilizada nas comunidades surdas e o que se torna relevante é a reivindicação pela interpretação das línguas orais para as línguas sinalizadas. Além disso, Perlin (2004) ressalta a necessidade da luta contra a violência 
cultural silenciosa praticada de forma mais evidente em outras épocas como, por exemplo, a proibição do uso da língua de sinais e a imposição do desenvolvimento e uso de línguas orais, próprias das culturas ouvintes e seus precedentes, concluindo que:

\begin{abstract}
A cultura surda tem de ser negociada em vez de negada [...] ela não está aí para uma subversão, mas com uma estratégia dos surdos para a sobrevivência. [...] o que é crucial para o ouvinte é simplesmente transformar a noção de que há uma única cultura e aventurar-se pelo espaço do que significa viver no diferente. (PERLIN, 2004, p.80).
\end{abstract}

Para finalizar os exemplos enunciativos que proclamam a cultura surda, recorro ao texto legislativo presente no Decreto $\mathrm{n}^{\circ} 5.626$ de 22 de Dezembro de 2005 (BRASIL, 2005) que afirma que a pessoa surda é aquela que manifesta sua cultura ao usar a língua de sinais. Ou seja, mais uma vez, se estabeleceu um vínculo entre língua e cultura. Outros documentos legislativos ou de políticas públicas, especialmente, na área educacional, oriundos tanto do governo Federal, quanto de diferentes Municípios e Estados do Brasil, também mencionam a relevância ou o caráter "existencial” da ideia de cultura surda.

Diante do que foi exposto fica evidente que os enunciados produzidos sobre a cultura surda já se tornaram saberes constituídos e presentes em diferentes instâncias da sociedade, com ênfase, na área educacional/acadêmica, religiosa e política. Tal fato tem permitido que, paulatinamente, a cultura surda se constitua e se fortaleça como uma construção discursiva com status de verdade e que se baseia, fundamentalmente, conforme demonstram os diferentes exemplos de enunciados, na ideia de uma cultura que estabelece relações por meio do uso de uma língua na modalidade visual-motora e com a construção identitária das pessoas surdas, o que a autoriza como singular frente às outras culturas que se constroem sob outros princípios discursivos.

Em continuidade à fundamentação teórica desta pesquisa estabelecerei uma discussão centrada no processo de construção identitária dos membros das comunidades surdas e em suas produções culturais no próximo capítulo, e deixarei a abordagem sobre a língua de sinais para a terceira parte da fundamentação teórica. 


\section{COMUNIDADES SURDAS: CONSTRUÇÕES IDENTITÁRIAS E PRODUÇÕES CULTURAIS}

Neste capítulo discutirei as construções discursivas que permeiam as possíveis formações identitárias das pessoas surdas no interior das comunidades surdas tendo como premissa o contexto afirmativo do "ser" surdo enquanto diferença linguística e cultural. Para tanto, me embasarei não apenas em autores que tratam, especificamente, do tema identidade surda, mas também em autores cujas produções problematizam as questões contemporâneas sobre o tema identidade se filiando aos Estudos Culturais, aos estudos de gênero e sexualidade e aos estudos críticos pós-coloniais.

E na segunda parte focarei no conjunto de enunciados que afirmam a cultura surda de acordo com as produções oriundas das comunidades surdas do Brasil, considerando as obras e/ou pesquisas que emergiram recentemente e que buscam evidenciar as peculiaridades culturais dessa comunidade.

3.1 As identidades sociais e individuais dos membros das comunidades surdas

No capítulo "A cultura surda no contexto dos Estudos Culturais" introduzi os enunciados propagados sobre a diferença em "ser" surdo no processo construtivo da ideia de cultura surda, e no presente texto traçarei uma linha argumentativa na tentativa de demonstrar como esse caráter de diferenciação, em termos culturais, pode influenciar na constituição dos enunciados que afirmam as denominadas identidades surdas.

Autores como Hall (2012), Bhabha (2013), Silva (2012) e Woodward (2012) tem abordado em suas produções o caráter indissociável entre a diferença e a identidade, dentro de uma perspectiva que considera que ambas são criações enunciativas, tanto sociais quanto culturais, sujeitas às relações de poder que se encontram em disputa na sociedade.

Conforme enfatiza Silva (2012, p. 81):

$\mathrm{Na}$ disputa pela identidade está envolvida uma disputa ampla por outros recursos simbólicos e materiais da sociedade. A afirmação da identidade e a enunciação da diferença traduzem o desejo dos diferentes grupos sociais, assimetricamente situados, de garantir o acesso privilegiado aos bens sociais. 
Os grupos sociais formados por pessoas surdas, são um desses grupos que tem buscado também esse acesso de bens. No entanto, as pessoas surdas, em sua maioria, quando nascem no seio de famílias ouvintes, geralmente, só estabelecem o contato com seus pares, ainda na infância, quando estudam em escolas para surdos, ou quando isso não acontece os contatos com outros surdos só ocorrem na fase da adolescência ou quando adultos nos lugares nos quais muitos membros das comunidades surdas costumam se reunir como, por exemplo, terminais de ônibus, praças, shopping centers, associações, entre outros.

São poucos os pais ouvintes com filhos surdos que procuram lugares e/ou pessoas que favoreçam a aquisição da língua de sinais e respeitem o "ser" surdo, de acordo com o discurso da diferença, contribuindo para os processos de identificação dessas crianças. Apesar da construção discursiva dentro dessa perspectiva ter ganhado força de verdade, como já tratei anteriormente, ela não é uma premissa amplamente adotada na área da saúde, nos primeiros anos de vida de qualquer criança, essa é uma das áreas que exerce maior influência, em termos discursivos, no ambiente familiar. Dessa forma, estabelecer relações de identificação baseadas nas formas de "ser" surdo, desde o nascimento, é uma possibilidade mais fecunda quando se trata de crianças surdas que nasceram em famílias cujos pais também são surdos, pois estes podem propiciar experiências de vida que não obedecem, necessariamente, às normas estabelecidas pelos outros, no caso, os ouvintes.

Tais experiências de vida, ao serem compartilhadas, são afirmadas como favorecedoras do acesso e interpretação de mundo de forma singular e por isso são proclamadas sob a premissa do contato surdo-surdo. Nesse sentido, tanto os locais de encontro das comunidades surdas, quanto as escolas para surdos, se constituem como espaços simbólicos imprescindíveis para promover o encontro entre os mesmos, principalmente, quando os surdos são provenientes de famílias ouvintes.

No que concerne ao espaço escolar, este ao longo da história da educação e de vida dos surdos foi - e ainda é - muito influenciado pelas práticas discursivas ouvintistas dos profissionais que nele trabalham ${ }^{8}$. No entanto, os contatos diários estabelecidos entre os alunos surdos em sala de aula, nos corredores, no refeitório, no banheiro, na quadra, na entrada da escola ou até mesmo nos meios de transporte utilizados por eles e, frequentemente, longe dos olhares e vigilância dos ouvintes, favorecem e ampliam tanto as trocas linguísticas e culturais entre essas crianças, quanto contribuem para constituição das identidades individuais e sociais das mesmas.

\footnotetext{
${ }^{8}$ No próximo capítulo tratarei de forma pormenorizada das práticas discursivas ouvintistas na história da educação de surdos.
} 
Cabe esclarecer que tomo como princípio que a ideia que coloco em torno das identidades individuais e das identidades sociais encontra-se em consonância, respectivamente, com a identidade para si e a identidade para o outro, em um contexto em que "eu nunca posso ter certeza de que minha identidade para mim mesmo coincide com minha identidade para o Outro. A identidade nunca é dada, ela sempre é construída e deverá ser (re)construída em uma incerteza maior ou menor e mais ou menos duradoura" (DUBAR, 2005, p. 135)

A seguir transcrevo um enunciado de um surdo que pode exemplificar o processo de reconstrução identitária:

Minha irmã contou-me sobre a Escola para surdos de Maryland. [...] Minha reação imediata foi de raiva e rejeição - de mim mesmo. Com relutância, eu a acompanhei à escola um dia - e finalmente comecei a chegar a minha casa. Foi de fato uma experiência de amor. Pela primeira vez, senti-me menos um estranho numa terra estranha e mais como um membro de uma comunidade. (SACKS, 1998, p. 150, apud SHEIN, 1989, grifo do autor).

Conforme consta no enunciado, o sentir-se estranho baseava-se nas experiências que esse surdo teve quando se relacionava apenas com ouvintes, e qual não foi sua surpresa ao se encontrar com outras pessoas também surdas no ambiente escolar, este foi denominado como sua casa e lhe proporcionou a oportunidade de "ser" membro de uma comunidade.

De forma complementar, Lopes (2004) aponta que dentro do ambiente escolar existe a possibilidade de negociações das identidades surdas de forma contínua e que essas negociações podem gerar outras formas de identificações surdas decorrentes do uso comum de uma modalidade linguística visual-motora, a partir da relação com as diferenças presentes entre os surdos que compartilham esse mesmo espaço.

Porém, muitos surdos que moram em regiões mais afastadas dos grandes centros urbanos, em pequenas cidades, podem não ter acesso e oportunidade de compartilhar o contato com outros surdos ainda durante a infância e em alguns casos permanecem assim pelo resto de suas vidas.

Teske (2005) relata a experiência que teve em Palmas no Tocantins ao encontrar muitos surdos que não tinham contato entre si e que se comunicavam com alguns sinais caseiros voltados à comunicação simples e imediata. Esses surdos eram tratados como incapazes, alguns estavam reclusos da vida em sociedade, eram considerados como "deficientes auditivos" e encarados como pessoas dependentes de outras para viver. Os olhares e as formas de identificação desses surdos por parte dos ouvintes eram estereotipados, inclusive, em registros de órgãos públicos. 
Os estereótipos criados sobre as pessoas surdas - e nessa reflexão incluo também pessoas que são ouvintes que não obedecem aos padrões eurocêntricos - de acordo com Bhabha (2013), recaem tanto em cenas de fantasia, quanto de defesa em torno de uma busca por uma originalidade que se encontra ameaçada quando se considera as diferenças. Conforme afirma o autor:

O estereótipo não é uma simplificação porque é uma falsa representação de uma dada realidade. É uma simplificação porque é uma forma presa, fixa, de representação que, ao negar o jogo da diferença (que a negação através do Outro permite), constitui um problema para as representações do sujeito em significações de relações psíquicas e sociais. (BHABHA, 2013, p. 130).

Um exemplo que discuti sobre um desses estereótipos que fixa o sujeito, no caso do surdo, ocorre quando este é localizado na perspectiva da deficiência, do patológico e da ausência, isto é, quando ele é denominado como "surdo-mudo" ou como "deficiente auditivo", negando o jogo da diferença quando ele se assume como surdo, frente ao outro, o ouvinte.

Mas Bhabha amplia nossa visão com exemplos de estereótipos ao se dedicar à análise da obra de Frantz Fenon "Pele negra, máscaras brancas" (2008). Esse autor afirma que independentemente do lugar em que o negro esteja, ele sempre permanecerá negro. Analogamente, o surdo sempre permanecerá surdo (mesmo se esse fizer uso do AASI ou tiver IC, que são paliativos que não eliminam a surdez). Em ambos os casos há uma marca da diferença negativa; no caso da pessoa negra "o estereótipo impede a circulação e a articulação de 'raça' a não ser em sua fixidez enquanto racismo" (BHABHA, 2013, p. 131, grifo do autor); já no caso do surdo, parafraseando Bhabha, o estereótipo impede a circulação e a articulação da surdez a não ser em sua fixidez enquanto deficiência.

Voltando apenas para a questão da surdez - em breve retomarei a questão de raça - as possibilidades de se reconhecer, se assumir dentro da perspectiva da diferença desestabilizando essa fixidez, no caso do surdo, são sensivelmente profícuas, principalmente, em centros urbanos onde os espaços de encontro das comunidades surdas já estão estabelecidos. Nessas comunidades mesmo que muitos surdos durante a infância tenham sido privados do convívio com outros surdos no ambiente escolar ou familiar, ao alcançarem idades de maior independência, começam a frequentar ambientes sociais ou pontos de encontro onde se reúnem diversos surdos que partilham e discutem experiências, ideias, opiniões, conhecimentos que podem se distanciar ou até mesmo se contrapor ao discurso ouvintista. 
Nesse sentido, as comunidades surdas podem ser compreendidas como locais simbólicos onde se estabelece um conjunto de relações sociais que possibilitam o compartilhamento e a luta por interesses e objetivos em comum, tanto entre surdos, quanto entre surdos e ouvintes, especialmente, por meio do uso das línguas de sinais, já que estas, de acordo com Behares:

[...] oferece às pessoas surdas um símbolo de inserção a uma unidade interpessoal com um lugar social próprio. Por trás desse símbolo, há um conjunto muito complexo de sentimentos, crenças e traços culturais que permitem a coesão grupal e a elaboração de objetivos alternativos de vida. (2009, p. 132, grifo do autor).

Para o surdo, o fato de fazer parte das comunidades surdas pode favorecer o sentimento de inclusão, de pertencimento sociocomunicativo, e assim pode ocorrer, mesmo que de uma forma um pouco diferente, talvez "fronteiriça", com o ouvinte que tem contato próximo e constante com o surdo e também desenvolve essa sensação de pertencimento. Porém para o outro, no caso o ouvinte não usuário de línguas de sinais, e cujo pertencimento está vinculado às comunidades ouvintes, fazer parte das comunidades surdas pode significar um processo de exclusão. Como exemplo, me remeterei a um enunciado que Sacks relata em sua obra sobre uma mãe de uma criança surda:

Pais ouvintes de crianças surdas enfrentam questões especialmente delicadas e
angustiantes de laços familiares e identidade. Uma mãe desse tipo, por exemplo,
escreveu-me sobre seu filho que ficara surdo aos cinco meses devido a uma
meningite: "Isso significa que da noite para o dia ele subitamente se tornou um
estranho para nós, que de algum modo ele não nos pertence mais, e sim ao mundo
dos surdos? Que ele agora é parte da comunidade surda, que não temos direitos
sobre ele?" [...] "Enquanto os cuidados e o sustento dele estão em nossas mãos,
prossegue minha correspondente, "acho que ele precisa ter acesso à nossa língua, do
mesmo modo que tem acesso à nossa comida, nossas peculiaridades, nossa história
familiar." (SACKS, 1998, p. 131, grifo do autor).

Nesse enunciado a mãe encontra-se na posição do outro e expressa claramente seu incômodo frente à suposta situação de exclusão de pertencimento as comunidades surdas, e ao mesmo tempo assume uma postura que para ela é inclusiva, ao negar que a criança faça parte dessas comunidades e seu vínculo sociocomunicativo ocorra no ambiente familiar ouvinte.

Tajfel (1983), situado dentro do campo da psicologia social, expõe alguns aspectos que favorecem a reflexão sobre a relação dialética existente nos contextos e relações a partir das quais as pessoas desenvolvem o pertencimento subjetivo a um grupo em detrimento de outro. O autor coloca três princípios que podem favorecer essa situação, sendo eles: a consciência de pertencimento da pessoa a um grupo decorrente da imposição de situações sociais de pouca identificação com outros grupos; as avaliações negativas e positivas que 
serão feitas a partir desse pertencimento; e por fim, as investidas emocionais tanto na consciência quanto nas avaliações de pertencimento. De acordo com esse autor:

As situações sociais que obrigam os indivíduos envolvidos a agir segundo sua
pertença de grupo, também acentuam neles certas identificações de grupo que antes
não tinham grande significado para eles, ou talvez criem mesmo ou despertem
pertenças de grupos antes adormecidas ou só potenciais. Como consequência e
segundo o primeiro princípio, muitas dessas pessoas terão, provavelmente, a
percepção comum dum número e variedade cada vez maior de situações sociais, de
alguma maneira relevantes para as suas pertenças de grupo. (TAJFEL, 1983, p. 272).

Analisando tais aspectos no contexto da formação simbólica das comunidades surdas, os surdos ao estabelecer o contato com pessoas ouvintes usuárias de línguas de modalidade oral-auditiva, podem ter poucas possibilidades de interação e participação em situações sociais com tais pessoas. São muitos os surdos que relatam as dificuldades e o isolamento social que sofreram no ambiente familiar e escolar quando lhes deram apenas a opção de convívio com sujeitos ouvintes e o acesso somente às línguas orais. Dessa maneira, sua consciência e avaliação de pertencimento nesse grupo podem se tornar baixas ou até mesmo inexistentes.

Em contrapartida, os mesmos surdos relatam de forma consciente e positiva o quanto sua vida mudou ao entrar em contato com outros surdos e que fazem o uso de línguas de sinais, ou até mesmo com ouvintes que também fazem uso dessas línguas como forma de comunicação. E por mais que existam grandes diferenças individuais entre cada membro das comunidades surdas, as relações que desenvolvem e compartilham trazem em comum diversas situações sociais cotidianas que passam despercebidas ou que provocam outros efeitos no grupo composto apenas por ouvintes.

As comunidades surdas acabam se constituindo como um dos diversos grupos minoritários presentes na sociedade e, como boa parte deles, não são grupos minoritários em função da quantidade de membros, mas em termos de expressividade discursiva nas relações de poder e saber estabelecidas. O exercício do poder entre os grupos majoritários e minoritários está pautado no que Foucault (2013a, p. 288) menciona como o conjunto de ações sobre ações possíveis: "ele incita, induz, desvia, facilita ou dificulta, amplia ou limita, torna mais ou menos provável; no limite, coage ou impede absolutamente, mas é sempre um modo de agir sobre um ou vários sujeitos ativos, e o quanto eles agem ou são suscetíveis de agir".

De forma complementar, no que concernem as minorias sociais, compartilho os critérios adotados por Tajfel (1983) que utilizou como referência os autores Wagley e Harris (1958) e Simpson e Yinger (1965): 
(1) as minorias são sectores subordinados de complexas sociedades de estado; (2) as minorias possuem traços culturais e físicos específicos pelos quais os sectores dominantes da sociedade mostram pouco apreço; (3) as minorias constituem unidades conscientes de si próprias, ligadas entre si pelos traços específicos comuns aos seus membros e pelas incapacidades específicas que esses traços provocam; (4) a pertença a uma minoria é transmitida por uma regra descendente através da qual é obtida a afiliação da geração vindoura, mesmo quando não aparentes; (5) os povos minoritários tendem a casar-se, por opção ou por necessidade, com membros do mesmo grupo. (SIMPSON; YINGER, 1965, p. 17 apud TAJFEL, 1983, p. 352).

Ao analisar as comunidades surdas de acordo com tais critérios faço as seguintes colocações:

(1) as comunidades surdas se constituem como minorias que estão subordinadas às sociedades de estado, e assim como outras comunidades, estão imersas nas relações de poder e saber que implicam ações sobre outras ações entre os sujeitos ativos;

(2) a surdez enquanto traço físico marca a diferença do ponto de vista dos surdos, e se caracteriza como um estigma do ponto de vista dos ouvintes. As línguas de sinais se apresentam como um dos principais traços culturais desse grupo minoritário, e mesmo que algumas línguas de sinais tenham sido reconhecidas oficialmente em diferentes países, muitos ouvintes as desconhecem e ainda lhes atribuem status inferior perante as línguas orais;

(3) e (4) as comunidades surdas além de estarem crescendo em termos de visibilidade, têm valorizado o sentimento de pertencimento e articulado movimentos para alcançar diversos interesses em comum, e isso tem ocorrido entre seus membros de uma geração para outra (mesmo que seja na fase da adolescência ou adulta), propagando e consolidando, inclusive, um conjunto de enunciados em torno da ideia de cultura surda;

(5) além desses itens, há os casamentos ocorridos, em sua grande maioria, entre os próprios surdos sob a justificativa de maior facilidade em termos comunicativos e compartilhamento de interesses em comum.

Dessa maneira, enquanto grupo minoritário os membros da comunidade surda constroem identidades sociais que ultrapassam os limites físicos individuais e os limites de grupo. Considerando o que abordei pode-se afirmar que a construção das identidades sociais conta com o outro e, conforme reitera Pollak (1992, p. 204), “a construção da identidade é um fenômeno que se produz em referência aos critérios de aceitabilidade, de admissibilidade, de credibilidade, e que se faz por meio da negociação direta com outros”.

Levando em consideração, momentaneamente, apenas a condição de "ser" surdo ou "ser" ouvinte, as negociações dos surdos, desde a infância, quando nascem surdos ou adquirem a surdez muito cedo, perpassam pelos ouvintes que colocam em jogo padrões de normalidade sociocomunicativa, pelos ouvintes que aceitam a diferença linguística e cultural 
e estabelecem relações no interior das comunidades surdas, pelos surdos que são oralizados e que fazem parte ou não das comunidades surdas, pelos surdos que fazem uso das línguas de sinais, entre outros. Tais negociações implicam tensões nos diversos processos em torno da construção identitária ao longo da vida dos indivíduos. Nesse sentido:

\begin{abstract}
As identidades podem funcionar, ao longo de toda a sua história, como pontos de identificação e apego apenas por causa de sua capacidade para excluir, para deixar de fora, para transformar o diferente em "exterior", em adjeto. Toda identidade tem, à sua "margem", um excesso algo a mais. A unidade, a homogeneidade interna que o termo "identidade" assume como fundacional não é uma forma natural, mas uma forma construída de fechamento: toda identidade tem necessidade daquilo que lhe "falta" - mesmo que esse outro que lhe falta seja um outro silenciado e inarticulado. (HALL, 2012, p. 110).
\end{abstract}

Aproveito o ensejo para ressaltar que as comunidades surdas não se compõem apenas de sujeitos surdos e sujeitos ouvintes como agrupamentos uniformes, muito pelo contrário, dentro das comunidades surdas existem pessoas com características bem distintas e que também influenciam no processo de construção das identidades sejam elas sociais ou individuais.

As identidades surdas, assim como as identidades ouvintes, atualmente podem ser compreendidas no contexto da pós-modernidade (HALL, 2006), já que ao levar em consideração que os sujeitos são constantemente influenciados pela multiplicação dinâmica das relações culturais em sociedades descentradas, as identidades, em seu processo de formação, também são influenciadas por este dinamismo. Por isso os sujeitos não podem ser cogitados como detentores de uma única identidade pelo resto de suas vidas, as identidades são frequentemente deslocadas, fragmentadas e representadas de acordo com os diferentes grupos sociais, dos espaços geográficos, dos momentos históricos e das relações culturais estabelecidas.

A determinação de uma identidade que apresente traços universais é praticamente impossível. Desta maneira, a identidade surda se torna plural, assim como qualquer outra identidade. Conforme alerta Woodward (2009) quando a política de identidade se torna pauta dos movimentos sociais de diferentes grupos, precisamos ter cautela para não proferirmos afirmações essencialistas que fixam e unificam a identidade com raízes apenas nos aspectos biológicos ou a identidade com raízes apenas nos aspectos históricos culturais.

Dentre os enunciados que circulam nas comunidades surdas facilmente encontra-se referência a identidade surda como uma espécie de essência. Como exemplos, menciono dois trechos retirados da obra "Mãos fazendo história" (2003), cuja iniciativa de escrita considero plausível por ter primado pelo registro das histórias de vida de vários surdos brasileiros. No 
entanto, ao longo das narrativas, foi possível encontrar algumas afirmações que demonstram certa fixação da identidade surda:

- Quando crianças, ninguém se importava por eu ser surda, somente queriam brincar.

As coisas mudaram, em sua visão quando começou a crescer... As amigas também cresceram, começaram as paqueras e a vergonha de ter uma surda no grupo, o relacionamento não era mais o mesmo, explicar para os meninos que ela era surda parecia tão difícil... Sylvia sentiu o preconceito pela primeira vez. E assim ela explica esse sentimento:

- Comecei a pensar igual a elas, ter vergonha de ser surda, comecei a me fechar.

Nesse momento da vida, Sylvia se depara com sua identidade surda e passa a se envolver com grupos de surdos onde sente-se plenamente aceita. (VERGAMINI, 2003 , p. 27, grifo meu).

No relato da vida de outra surda a narradora menciona a situação em que a surda realizou um teste para se tornar professora em uma escola para crianças surdas:

Como em toda situação de mudança, ficou com medo e apavorada.

Estranhava os Sinais, não entendia as crianças e professoras. Estava acostumada com a leitura labial.

Com o passar dos dias, das semanas, foi relaxando e se transformando...

Percebeu o quanto é importante o uso da Língua de Sinais na educação dos surdos.

Encontrou sua identidade surda. (VERGAMINI, 2003, p. 45, grifo meu).

"Se deparar com a identidade surda" ou "encontrar sua identidade surda", foram afirmações proferidas quando aconteceu o encontro surdo-surdo pelas surdas que relatavam suas histórias de vida. As relações sociocomunicativas ganharam outra dimensão frente às relações que eram estabelecidas anteriormente com pessoas ouvintes que desconheciam a língua de sinais. A impressão que se tem é que antes do encontro surdo-surdo, as surdas não tinham identidade, ou que suas identidades eram "abertas" ou "invisíveis", nas relações que elas tinham com o outro. Tomando posse dos termos de Hall (2012, p. 110), a identidade surda, desse ponto de vista, seria a uma "construção de uma forma de fechamento".

Essa forma de fechamento muitas vezes, no caso das comunidades surdas, desconsidera outras diferenças além do "ser" essencializado, e dentro desta linha argumentativa, sintetizo as principais características das cinco categorias das identidades surdas observadas e elencadas por Perlin (2005):

a- Identidades surdas correspondem aos surdos que fazem uso das experiências visuais e da comunicação visual. "Esta identidade cria um espaço cultural visual dentro de um espaço cultural diverso. Praticamente, esta identidade surda recria a cultura visual, reclamando à história a alteridade surda." "[...] Trata-se de uma identidade que se sobressai na militância do específico surdo" (PERLIN, 2005, p. 63); 
b- Identidades surdas híbridas predominam em ouvintes que se tornaram surdos, ou seja, pessoas que durante algum período tiveram experiências auditivas e internalizaram a estrutura da língua oral de seu país, no caso do Brasil a Língua Portuguesa, e que ao terem contato e começarem a usar a língua de sinais, captam os sinais, traduzem para a língua oral e só depois conseguem se expressar pela língua visual-motora;

c- Identidades surdas de transição podem ser observadas em surdos que foram mantidos dentro das normas estipuladas pelos ouvintes durante algum tempo, principalmente quando são surdos filhos de pais ouvintes. "Transição é o aspecto do momento de passagem do mundo ouvinte com representação da identidade ouvinte para a identidade surda de experiência mais visual" (PERLIN, 2005, p. 64). Esse processo é colocado pela autora como "des-ouvintização";

d- Identidades surdas incompletas se atrelam aos surdos que tiveram uma experiência negativa ao se aproximar e conviver com outros surdos, ou por surdos que estão vinculados às normas ouvintes e que tentam influenciar os outros surdos, para que estes façam parte da comunidade majoritária;

e- Identidades surdas flutuantes se caracterizam pela forte influência ouvinte exercida sobre os surdos, determinando comportamentos e aprendizados que provocam tanto a ausência de comunicação dos surdos para com os ouvintes, quanto de surdos com outros surdos. "Existem alguns surdos que querem ser ouvintizados a todo custo. Desprezam a cultura surda, não tem compromisso com a comunidade surda. Outros são forçados a viverem a situação como conformados a ela" (PERLIN, 2005, p. 65) e criam novas visões sobre sua condição de "ser", bem como do que os cercam.

De acordo com a classificação de Perlin (2005) e os dois exemplos de enunciados que mencionei do livro "Mãos fazendo história" (2003), as surdas que expuseram sua situação e o contexto abordados pelas narradoras permitem que as identidades delas sejam localizadas, inicialmente, como Identidades surdas de transição, pois ambas tinham contato com ouvintes e seguindo a lógica discursiva dentro dessa perspectiva, somente quando começaram a estabelecer o contato surdo-surdo é que as Identidades surdas se tornaram possíveis.

Para Strobel (2008, p. 33) “muitas vezes a formação das identidades surdas é construída a partir de comportamentos transmitidos coletivamente pelo 'povo surdo', que ocorre espontaneamente quando os sujeitos surdos se encontram com os outros membros surdos nas comunidades surdas". Nesse contexto, cabe esclarecer que como "povo surdo" Strobel (2008, p. 34) compreende: 
[...] sujeitos surdos que compartilham, história, tradições em comuns, e pertencentes às mesmas peculiaridades culturais, ou seja, constrói sua concepção de mundo através do artefato cultural visual, isto é, usuários defensores do que se diz ser povo surdo, seriam os sujeitos surdos que podem não habitar no mesmo local, mas que estão ligados por um código de formação visual independente do nível linguístico.

De forma análoga, tais enunciados correspondem, de certa forma, aos enunciados que proclamam a representação das identidades nacionais como unificadas de acordo com os sentidos que são produzidos discursivamente sobre as culturas nacionais de cada país, mas no caso em questão, trata-se das identidades surdas e da cultura surda. Hall (2006, p. 60) esclarece que em torno dessas narrativas a diferença de "raça", gênero e classe é unificada numa identidade cultural no sentido de construção de uma grande família nacional, no entanto, chama a atenção ao afirmar que "uma cultura nacional nunca foi um simples ponto de lealdade, união e identificação simbólica. Ela é também uma estrutura de poder cultural”.

A tendência de se unificar as identidades nacionais se assemelha ao movimento discursivo nas comunidades surdas na tentativa de se unificar as identidades surdas como identidades sociais que emergem de um determinado "povo", na terminologia de Strobel (2008) o "povo surdo". Porém, compartilho com Hall (2006) a ideia de que o hibridismo cultural presente nas sociedades modernas impede a tentativa de se unificar as identidades sob a argumentação da suposta existência de um "povo" como uma prerrogativa fundacional.

Os enunciados demonstram que as relações de poder em torno das identidades surdas estão focadas, principalmente, nas identidades surdas, de Perlin (2005), como identidades almejadas e positivamente aceitas nas comunidades surdas, como tentativas de resistência frente às identidades ouvintes. No entanto, no processo de constituição da alteridade surda há uma forte tendência à dependência de representações ouvintes, já que "a presença do ouvinte nas narrativas surdas - como sendo o opositor binário do surdo - afasta o próprio surdo da possibilidade de fazer, de si mesmo, uma posição de referência a sua condição de ser surdo" (LOPES; VEIGA-NETO, 2006, p. 85).

E quando os enunciados focam apenas nas identidades surdas, e tomam apenas o surdo como referência não se encontra isenção na propagação de outros padrões, dessa vez, baseados na normalidade do que seria "ser" surdo. As demais identidades surdas e as diferenças de classe, gênero e "raça" ficam em segundo plano ou nem sequer são mencionadas. 
Porém, os surdos fazem parte de outras minorias sociais que também podem contribuir ou influenciar nas identidades sociais das comunidades surdas e nas identidades individuais de seus membros como discorrerei a seguir.

Garcia (2009), num estudo realizado nos Estados Unidos sobre os aspectos culturais e a educação de surdos, problematizou o fato de que as questões de "raça" eram, aparentemente, irrelevantes ou invisíveis para a comunidade surda americana, já que a surdez era considerada como uma característica primária tanto pelos ouvintes quanto pelos próprios surdos.

A autora ainda cita que diante desta situação muitos surdos nos Estados Unidos de origem afro-americana, asiático-americanos, hispânico/latino-americanos e índios-americanos criaram suas próprias organizações desvinculadas da Associação Nacional de Surdos. A "motivação tem sido defender suas necessidades como surdos e membros de minorias raciais e culturais e como pessoas que possuem identidades múltiplas e complexas" (GARCIA, 2009, p. 156).

No Brasil ainda não percebemos a organização de associações semelhantes, talvez por conta do discurso nacional se pautar na miscigenação de diversas raças e na ideia de "igualdade" étnico-racial e na "invisibilidade" construída no seio da população brasileira.

No entanto, entre os anos de 2008 e 2013, ocorreram quatro edições do "Congresso Nacional de Inclusão Social do Negro Surdo", cuja iniciativa partiu dos surdos negros militantes na comunidade surda da cidade de São Paulo. As realizações desses eventos são propostas que refletem a necessidade da promoção de debates que favoreçam reflexões acerca do processo de reconhecimento e respeito das múltiplas identidades, dos constantes processos de contato e trocas culturais que os surdos estão sujeitos e que podem se estender as demais origens étnico-raciais, linguísticas e culturais engendradas na sociedade brasileira.

Com relação às diferenças de gênero e sexualidade, no Brasil já existem associações Lésbicas, Gays, Bissexuais e Transexuais (LGBT) para surdos ${ }^{9}$ e estudos como o de Moreira (2005, p. 103) que atentam para o fato de que "a mulher surda e suas relações de gênero e sexualidade exigirá olhares que busquem perceber como os saberes sobre a surdez se constituíram na modernidade; perceber as coisas que são ditas em relação a ela, sobre ela; como ela é referida e se refere a si própria".

\footnotetext{
${ }^{9}$ Pode-se encontrar algumas notícias e vídeos disponíveis na internet, que citam a Associação Paranaense de LGBT surdos (APLS) e a Associação de Surdos LGBT do Ceará.
} 
De acordo com o que abordei várias são as possibilidades do processo de construção das identidades dos sujeitos surdos e da construção das identidades sociais das comunidades surdas. Por meio das múltiplas formas de ser, se ver, ver os outros e a sociedade que os rodeiam, os surdos se articulam, se organizam e fortalecem os paradigmas constitutivos das culturas, histórias e memórias das comunidades surdas. Porém, isso não significa que as comunidades surdas estejam imunes às tentações de fixação e unificação tanto identitárias, quanto culturais.

Recorrer à fixação e unificação pode refletir a resistência e muitas vezes a necessidade de oposição às culturas, histórias e memórias oriundas das comunidades, predominantemente, ouvintes. De acordo com Nora (1993, p. 17):

\begin{abstract}
A passagem da memória para a história obrigou cada grupo a redefinir sua identidade pela revitalização de sua própria história. O dever da memória faz de cada um o historiador de si mesmo [...]. Todos os corpos constituídos, intelectuais ou não, sábios ou não, apesar das etnias e minorias sociais, sentem a necessidade de ir em busca de sua própria constituição, de encontrar suas origens.
\end{abstract}

As comunidades surdas, dentre outras minorias sociais, foram excluídas das narrativas dos mais diversos acontecimentos históricos. Ao consultarmos livros, arquivos, jornais, dentre outros documentos, raramente, verifica-se a alusão às pessoas surdas; foi como se elas não fizessem parte da sociedade, não tivessem presenciado ou vivenciado períodos de Guerra, ditaduras militares, revoluções, revoltas ou manifestações sociais que fizeram parte da realidade de diversas nações e/ou regiões. E quando encontramos algum registro em outros contextos sociais que citam os surdos, geralmente, eles são descritos de forma estereotipada ou ligada ao discurso da deficiência e normalidade sociocomunicativa ouvinte; então, o que se observa, na atualidade, são movimentos das comunidades surdas em busca de suas "origens" e "heranças".

Para finalizar a primeira parte deste capítulo, em consonância com a reflexão de Hall (2006), as identidades na era da globalização não podem ser fixadas em apenas um lugar, já que elas estão constantemente passando por processos de transição. Porém, ao me voltar para as identidades surdas, não tomo essa transição no sentido do que foi descrito por Perlin (2005) e que se remete apenas ao processo de transição das identidades ouvintes para identidades surdas. Considero as identidades surdas em processos de transição entre as múltiplas possibilidades de deslocamento, desvios e identificações permitidas quando se cogita, sobretudo, os processos de hibridismos culturais, linguísticos, étnico-raciais, de classes, e de gênero e sexualidade. Dessa forma, amplio a diferença em "ser" surdo no tempo 
e contexto histórico em que não apenas as comunidades surdas estão imersas, mas que boa parte das comunidades, seja ela enunciada como majoritária ou minoritária, se constitui simbolicamente no mundo globalizado.

3.2 As comunidades surdas como produtoras de culturas

Tomando posse do que discorri pode-se perceber que as comunidades surdas atuam simbolicamente como espaços que contribuem para os processos de identificação de seus membros. Essas comunidades também são cada vez mais afirmadas como "locais" onde se compartilha e se produz relações e traços culturais próprios, como tentarei demonstrar a seguir.

A publicação de Strobel (2008), "As imagens do outro sobre a cultura surda", foi uma das pioneiras obras realizadas por pesquisadores surdos brasileiros que se dedica justamente à cultura das comunidades surdas do Brasil. Essa obra tem sido, frequentemente, tomada como referência em diversos estudos quando o assunto em questão permeia a cultura surda. Nela observa-se a presença de muitos enunciados de surdos que, de acordo com a linha argumentativa da autora, deixam claro como a cultura surda tem se constituído discursivamente e materialmente.

Para começar sintetizo o que a autora concebe como artefatos culturais produzidos, principalmente, por surdos brasileiros de diferentes localidades e campos de atuação nas e para as comunidades surdas. No contexto do livro a terminologia "artefatos culturais" é definida não só como:

[...] formas individuais de culturas materiais, ou produtos definidos da mão-de-obra humana; também podem incluir "tudo o que se vê e se sente" quando se está em contato com a cultura de uma comunidade, tais como materiais, vestuário, maneira pela qual um sujeito se dirige a outro, tradições, valores e normas, etc. (STROBEL, 2008, p. 37).

Nessa obra, a autora apresenta e descreve oito do que ela denomina como "artefatos culturais". Estes contemplam a exemplificação da chamada experiência visual dos surdos; a aquisição e o desenvolvimento linguístico dos mesmos; a constituição e caracterização familiar; a produção e divulgação da literatura surda; a vida social e esportiva; as formas de expressões por meio das artes visuais; o movimento político; e, por fim, os recursos materiais 
produzidos e utilizados pelos surdos. A seguir, elucidarei, brevemente, algumas das principais características dos "artefatos culturais” elencados por Strobel (2008).

“Artefato Experiência Visual”: se faz presente nos sujeitos surdos desde o momento que nasceram ou ficaram surdos. Tudo o que acontece ao redor dos surdos é percebido visualmente e se vincula com a relação simbólica, a forma de agir em determinadas situações, de perceber as pessoas e os acontecimentos, na maneira de se comunicar e no desenvolvimento das expressões corporais e faciais.

Com a necessidade de acesso e compartilhamento de experiências visuais os surdos também promovem reivindicações em espaços públicos e meios de comunicação para existência de recursos visuais que permitam a acessibilidade comunicativa e informativa.

“Artefato Linguístico": este "artefato" inclui a língua de sinais e a comunicação por meio de sinais caseiros desenvolvidos no seio de famílias ouvintes que tem um surdo privado de contato com as comunidades surdas.

A língua de sinais é considerada pela autora como um dos quesitos mais importantes não somente dentro do "artefato linguístico", mas também na influência que exerce na constituição identitária do surdo, e consequentemente, no desenvolvimento dos demais "artefatos culturais". Por isso, a aquisição o mais cedo possível dessa língua e o contato com surdos adultos são aspectos relevantes quando se tem em mente uma criança surda.

Strobel considera que:

A língua de sinais é uma das principais marcas da identidade de um povo surdo, pois é uma das peculiaridades da cultura surda, é uma forma de comunicação que capta experiências visuais dos sujeitos surdos, sendo que é esta língua que vai levar o surdo a transmitir e proporcionar-lhe a aquisição de conhecimento universal. (2008, p.44).

Assim, como qualquer outra língua, a língua de sinais sofreu mudanças ao longo dos anos, porém um fator determinante de diferenciação com as demais línguas é que é uma língua visual-motora e, por conta disso, a forma com que os surdos interagem em diversas situações comunicativas, apresenta algumas diferenças que não observadas nas línguas orais. Como exemplo, a autora menciona o fato dos surdos se comunicarem mesmo quando há certa distância entre os interlocutores e tendo barreiras como o vidro, ou o fato dos surdos que visitam outra cidade procurarem os pontos de encontro dos surdos da comunidade local para se conhecerem.

“Artefato Familiar": neste "artefato" foram apresentadas duas formas predominantes de influência na constituição identitária e no acesso cultural dos surdos. Tais formas se 
relacionam ao tipo de família que o surdo faz parte, ou seja, uma família surda ou uma família ouvinte.

O nascimento de uma criança surda é um acontecimento alegre na existência para a maioria das famílias surdas, pois é uma ocorrência naturalmente benquista pelo povo surdo que não veem está criança um "problema social" como ocorre na maioria das famílias ouvintes. (STROBEL, 2008, p. 49).

De acordo com a narrativa de Strobel, nas famílias compostas de surdos é desejável o nascimento de um bebê também surdo, afim de que seu desenvolvimento global seja natural. Inclusive, ao longo dos anos, para esta criança as famílias ouvintes é que se tornarão diferentes e causarão estranheza. Já o que, geralmente, ocorre nas famílias ouvintes é o contrário, há certo desespero com o nascimento de uma criança que não ouve e uma busca quase imediata de processos terapêuticos que tenham como finalidade uma aproximação do desenvolvimento desse surdo, ao modelo ouvinte, podendo provocar com o passar dos anos a falta, o atraso ou deturpações na aquisição e desenvolvimento da língua, identidade e do contato com aspectos próprios da cultura surda.

"Artefato Literatura Surda": tal "artefato" tem crescido e se configurando pelas histórias, poesias, piadas, lendas, entre outros gêneros que se referem:

[...] as várias experiências pessoais do povo surdo que muitas vezes, expõem as dificuldades e ou vitórias das opressões ouvintes, de como se saem em diversas situações inesperadas, testemunhando as ações de grandes líderes e militantes surdos e sobre a valorização de suas identidades surdas. (STROBEL, 2008, p. 56).

Os registros de tais produções ocorrem por meio de CD-ROM, DVDs e vídeos, quando realizadas em língua de sinais. Porém, existem produções como as autobiografias, os artigos e livros acadêmicos que são produzidos em Língua Portuguesa e registrados de forma impressa, além de produções expressas pela Libras ou Língua Portuguesa e pelo sistema SignWriting.

“Artefato Vida Social e Esportiva": nesse "artefato" são mencionadas a organização e participação em eventos sociais e esportivos, bem como alguns costumes próprios dos surdos.

A comunidade surda, de forma geral, adota determinados comportamentos sociais que buscam a reafirmação de suas identidades, dentre estes comportamentos a autora cita além dos casamentos endógamos, o grande desejo de gerar, a partir desta união, filhos surdos.

O "batizado" de todos os membros da comunidade com um sinal que é utilizado para identificar cada sujeito ao invés de soletrar o nome todas as vezes que se referem a ele também é uma prática recorrente. Quando uma pessoa começa a frequentar a comunidade 
surda, através do convívio com outros surdos, lhe é atribuído um sinal, que geralmente se vincula a alguma característica ou atributo marcante da pessoa (STROBEL, 2008).

Além disso, é narrada a organização de festas, eventos, encontros, formação de associações que visam a promoção do contato entre surdos por meio de práticas esportivas, artísticas e culturais. Tais acontecimentos não ocorrem apenas regionalmente e muitas vezes contam com a participação de surdos de várias cidades e estados brasileiros.

“Artefato Artes Visuais": as artes visuais são exemplificadas na comunidade surda pela interpretação e expressão artística de atores, dançarinos, contadores de histórias, poetas, escultores e pintores surdos, que utilizam o teatro, poesia, desenhos, pinturas, músicas sem som, entre outras manifestações que oportunizam a divulgação do pensamento e crenças da comunidade surda, além da possibilidade de novos olhares e interpretações sobre a cultura surda (STROBEL, 2008).

"Artefato Político": esse "artefato", para Strobel (2008), contempla todas as conquistas oriundas da organização dos surdos em associações, federações e confederações nacionais e mundiais, que inicialmente tinham objetivos mais práticos voltados à vida social e esportiva dos surdos. Porém, atualmente, tais objetivos têm assumido caráter político "nestas organizações reúnem sujeitos surdos em reuniões e assembleias para compartilharem dos mesmos interesses em comuns, lutando pelos seus direitos judiciais e de cidadania" (STROBEL, 2008, p. 72).

Dentre as reivindicações e conquistas dos surdos a autora cita o reconhecimento da Língua Brasileira de Sinais em 2002, o Dia do Surdo comemorado no dia 26 de setembro, além de conquistas no âmbito educacional e de acessibilidade comunicativa em locais públicos.

“Artefato Material": para finalizar, nesse item são considerados todos os materiais, que foram criados e que são utilizados para promoverem ou facilitarem a acessibilidade do surdo em sua vida cotidiana, respeitando sua condição de receptor, predominantemente, de estímulos visuais.

Como exemplo de alguns destes recursos materiais Strobel cita: campainhas e telefones que não tocam, mas acendem luzes, relógios que vibram, Telefone Device for the Deaf (TDD) onde é possível digitar o que será dito nas ligações, um tipo de dispositivo muito presente em vários lugares públicos das diferentes cidades do Brasil, legenda Closed-Caption nos programas de televisão, além das mensagens enviadas por aparelhos celulares, e programas de mensagens instantâneas via internet (STROBEL, 2008). 
Para finalizar, além de objetos e aparelhos eletrônicos e tecnológicos, a autora aponta que os surdos também necessitam e fazem uso dos serviços de Tils, além de recursos visuais como telões e cartazes.

Diante do foi exposto sobre um dos capítulos da obra de Strobel (2008) se torna evidente o processo de afirmação discursiva da cultura surda enquanto verdade. No entanto, o fato da autora ter adotado uma descrição de elementos que são tomados como próprios da cultura surda e classificados meramente como "artefatos", não condizem em sua totalidade ao que se pode considerar como "artefato cultural".

Os artefatos culturais podem ser compreendidos como os elementos mais superficiais de uma cultura por estarem ligados a uma noção material e externa do que é produzido pelas diferentes comunidades. Conforme alerta Williams (2011, p. 347) “uma cultura, enquanto está sendo vivenciada, não pode nunca ser reduzida a seus artefatos. No entanto, a tentação de observar apenas a evidência externa é sempre muito forte".

Porém, mesmo que a autora tenha se apoiado de forma generalizada do termo "artefato cultural”, muitos enunciados presentes em sua obra abordam como as comunidades surdas constroem todo um "modo de vida". E tal "modo de vida", enquanto invenção para a condição existencial das comunidades surdas, pode buscar alicerces não no que se torna evidente e materializado do que seria a cultura surda mas, como sugere Williams, "na ideia coletiva básica, [...] instituições, maneiras, hábitos de pensamento e intenções que se originam dessa ideia" (WILLIAMS, 2011, p. 351).

Por meio das descrições realizadas por Strobel (2008) há a tentativa de se objetivar a cultura surda, cuja construção discursiva está baseada, muitas vezes, entre alguns membros das comunidades surdas e pesquisadores surdos e/ou ouvintes, numa perspectiva de afirmação, e até mesmo fixação, frente às demais culturas.

Com a ampliação do reconhecimento e interesse das comunidades surdas como "locais" onde há a produção e a circulação da cultura surda, pode-se observar, discursivamente ou materialmente, as diferentes maneiras que esta cultura se constrói e se manifesta, e muitos dos processos de afirmação têm contemplado a premissa da divulgação e do consumo, como descrevei no subitem a seguir. 


\subsubsection{Produções culturais das comunidades surdas}

No meio acadêmico, observa-se a divulgação de pesquisas recentes sobre as produções culturais das comunidades surdas brasileiras como demonstram as autoras Karnopp, Klein e Lunardi-Lazzarin (2011) no texto intitulado "Produção, circulação e consumo da cultura surda brasileira".

Segundo as autoras:

As produções culturais de pessoas surdas envolvem, em geral, o uso de uma língua de sinais, o pertencimento a uma comunidade surda e o contato linguístico e cultural com pessoas ouvintes, que pode proporcionar uma experiência bilíngue/bicultural a essa comunidade, ou seja, experiências que se dão no campo visual. (KARNOPP; KLEIN; LUNARDI-LAZZARIN, 2011, p. 16).

As autoras tiveram como foco as produções culturais surdas que circulam formalmente e livremente, além daquelas oriundas de discentes da disciplina Literatura Surda, ao priorizarem, respectivamente, o campo editorial, a internet e o curso superior de Letras/Libras.

Na pesquisa, as produções culturais analisadas no campo editorial predominaram entre os anos de 1999 e 2010, em materiais como livros e DVDs, infantis e infanto-juvenis, além de obras informativas para professores. No entanto, as autoras ressaltaram o fato da existência de aspectos clínicos e de normalização em vários materiais, além de boa parte dos mesmos não terem sido produzidos por surdos, mas sim por profissionais da área da educação e reabilitação clínica da surdez.

Já as produções presentes na internet enfatizaram os vídeos que compreendiam encenações, contações de piadas e propagandas, dentre outras manifestações que circulam livremente no YouTube, e que podem ser resumidas da seguinte forma:

[...] os vídeos produzidos pelas associações de surdos, por exemplo, giram em torno da divulgação de eventos para a comunidade surda e demais interessados; os vídeos produzidos por líderes surdos de diferentes regiões do país apresentam como tema central a divulgação da língua de sinais, seja na forma de humor, piadas ou histórias. Em outros vídeos analisados, o conteúdo é mais de nível informativo, ou seja, eles se ocupam de fazer divulgações de utilidade pública, por exemplo: a Lei de Redução do IPI [Imposto sobre Produtos Industrializados] na compra de veículos e os adesivos existentes para identificação de motoristas surdos. Também há uma grande incidência de vídeos que divulgam softwares bilíngues - destacando alguns elementos da cultura surda, como campainha luminosa - e apresentação de peças de teatro em língua de sinais. (KARNOPP; KLEIN; LUNARDI-LAZZARIN, 2011, p. 24).

Dentre os vídeos observados pelas autoras aparece a preocupação e o direcionamento das produções não apenas para surdos, mas também para ouvintes usuários da língua de 
sinais. Mesmo havendo o predomínio de surdos atuando nos vídeos, verificou-se que os ouvintes participaram no processo de narração, legendagem e/ou sonorização de fundo, denotando a diferença linguística e a significação e legitimação da cultura surda, e a subjetivação dos surdos em ações discursivas e reproduções oriundas deles mesmos.

Por fim, tendo como foco os alunos que tinham como tarefa a produção ou tradução de obras literárias para a disciplina Literatura Surda do curso Letras-Libras de diferentes polos espalhados pelo país as autoras apontam que as produções dessas pessoas:

[...] estão marcadas pelas experiências que os surdos têm do uso da língua de sinais e da inserção em um ambiente familiar e escolar, em que circulam histórias preponderantemente em língua portuguesa. Ao analisar os materiais a maioria optou por traduzir fábulas e contos de ampla circulação [...] traduções de narrativas ou poemas, com uma tradução cultural, de textos de Esopo, La Fontaine, Hans Christian Andersen, Monteiro Lobato, Vinícius de Morais e textos bíblicos. Outros construíram narrativas mais detalhadas, sendo algumas delas relacionadas às suas experiências de vida, experiências escolares ou sociais. (KARNOPP; KLEIN; LUNARDI-LAZZARIN, 2011, p. 26).

Diante das análises realizadas as autoras apontam que "a cultura surda serve de base e garantia para fazer reivindicações da diferença no espaço público" (KARNOPP; KLEIN; LUNARDI-LAZZARIN 2011, p. 28) e essa diferença ganha destaque e caráter político que se sobressaem à materialização, às ideias e às narrativas culturais em si.

Para complementar, cito o exemplo de estudo realizado por Mianes, Müller e Furtado (2011) sobre a produção cultural das comunidades surdas, que foi centrado na literatura surda produzida somente por autoras surdas e que compreendiam poemas ("Meus sentimentos em folha" de Ronise Oliveira), romance ("Mãos ao vento" de Sylvia Lia Grespan Neves) e autobiografia ( "A verdadeira beleza: uma história de superação” de Vanessa Vidal).

De acordo com os autores da pesquisa, as narrativas de si analisadas recorrem a diferentes perspectivas e mencionam os processos de constituição identitária, o contato e uso das línguas de sinais, as comunidades surdas, as situações vividas pelos surdos, os desafios que os surdos enfrentam, as normalizações e práticas ouvintistas, as superações, a reivindicação da diferença, entre outros.

A circulação e consumo de obras literárias produzidas pelos próprios surdos demonstrarem uma abertura do campo editorial frente à identificação de um potencial mercado consumidor, que pode contribuir para evidenciar a diferença do "ser" surdo, incentivar outras produções culturais das comunidades surdas e favorecer a luta política. Porém, os autores alertam que:

A circulação desses materiais proporciona também a constituição de alguns comportamentos ou posicionamentos a que todos os surdos dever aderir, como, por exemplo, em relação à valorização da língua de sinais. Essa manifestação, por sua 
vez, pode até ser entendida como uma contradição, na medida em que a circulação da obra para além das comunidades surdas requer a publicação em português. Pressupomos, assim, que a escrita em português transcende a função expressiva e estética da literatura, pois em jogo também estão questões políticas e de constituição de significados. (MIANES; MÜLLER; FURTADO, 2011, p.59).

Para finalizar os exemplos de produção cultural, me remeterei à pesquisa "Literatura infantil do século XXI: surdez e personagens surdos" (SILVEIRA, R.; SILVEIRA, C.; BONIN, 2011) que centra a análise na representação sobre o surdo e a surdez em cinco obras literárias, publicadas entre os anos de 2006 e 2009 por autores e ilustradores do Brasil.

As obras foram "O feijãozinho surdo", "Mãos tagarelas e bocas sorridentes", "Um mistério a resolver: o mundo das bocas mexedeiras", cuja língua de sinais é apontada como uma peculiaridade da cultura surda, e que essa cultura se constrói através dessa língua; e as obras "Óculos de ouvido" e a "A casa amarela”, nas quais foram percebidos traços característicos da visão clínica da surdez, em diferentes níveis de acentuação.

Todas as obras são citadas como:

Conectadas com o momento que está sendo vivido pela comunidade surda brasileira
e com as discussões que estão ocorrendo em diversos fóruns e instâncias. [...] É
preciso registrar que, em vários aspectos e em grau variável, elas "padecem" do
compromisso pedagógico de ensinar aos pequenos leitores, incluídos os ouvintes, o
que é melhor para criança surda e o que é, enfim, ser surdo. Parece difícil - e não
por acaso a maioria dos autores são profissionais ouvintes que trabalham com a
comunidade surda e não escritores do "ramo" - elaborar uma trama ficcional que
simultaneamente incorpore doses maiores de polissemia, elementos inusitados e
surpreendentes e aborde a temática da cultura surda e da educação da criança, na
medida em que parece haver uma intenção pedagógica concreta. (SILVEIRA, R.;
SILVEIRA, C.; BONIN, 2011, p. 201).

Diante dos exemplos mencionados sobre algumas pesquisas que tiveram como foco a produção realizada e/ou consumida pelas comunidades surdas, bem como sobre a discussão que realizei anteriormente sobre os processos de construção de identidades, se tornam perceptíveis os movimentos e lutas que buscam a legitimação cultural, identitária e linguística pautada na diferença em "ser" surdo.

No entanto, tais movimentos ainda estão vinculados às negociações de poder e saber que envolvem, especialmente, as comunidades majoritárias e os processos de normalização, em sua maioria, centrado no outro ouvinte, e de forma menos expressiva, nos processos de normalização centrado no outro surdo.

Para concluir o presente capítulo, não poderia deixar de mencionar o fato de que ao mesmo tempo em que ocorre o fortalecimento e a propagação de um conjunto de enunciados próprio dos membros das comunidades surdas, muitos surdos que habitam em diferentes regiões do país, inclusive, em grandes centros urbanos, e que foram - até então - privados do 
encontro surdo-surdo e/ou que tem contato com práticas discursivas ouvintistas, desconhecem os movimentos que tem ocorrido em torno das possibilidades de compartilhamento e consumo das produções culturais das comunidades surdas. Principalmente quando são privados ou tem acesso restrito a outras possibilidades de "ser" em termos identitários e culturais, quando lhes é negada a aquisição de uma língua que cumpre funções de extrema relevância quando pensamos na condição que se atrela a noção de "ser humano", em nossa sociedade.

E será, justamente, sobre a relevância da língua, especificamente, da língua de sinais para o "ser", no caso, surdo, que dedicarei a discussão do próximo capítulo. 


\section{LÍNGUAS DE SINAIS}

Historicamente as línguas de sinais de todo o mundo permitiram - e permitem - não apenas a comunicação e o desenvolvimento da linguagem, contribuindo para estruturação do pensamento de seus usuários, mas também se tornaram primordiais para as diversas possibilidades de construção discursiva no processo de consolidação das comunidades surdas, como locais simbólicos onde se estabelecem as relações sociais, culturais e identitárias de seus membros, conforme abordei no capítulo anterior.

Dando continuidade à fundamentação teórica da presente pesquisa, este capítulo será dedicado à língua de sinais e a relevância que a mesma tem ganhado nos discursos centrados no "ser" surdo enquanto diferença, especialmente, no campo cultural e educacional.

Para tanto, iniciarei a explanação traçando um panorama, considerado como tradicional no campo da surdez, que perpassará pelas fases da educação de surdos. No entanto, durante a breve descrição de cada uma delas tentarei evidenciar as relações de poder e saber envolvidas nas construções discursivas que permearam tanto o processo de negação quanto de reconhecimento das línguas de sinais, me baseando em Foucault e em autores da área dos Estudos Surdos.

Após a exposição da fase mais atual no campo educacional concentrarei esforços na expansão da permeabilidade da língua de sinais nas políticas públicas e no meio acadêmico, especificamente, no cenário brasileiro, fato que tem apontado para ampliação de normatividades que podem favorecer que essa língua, seus usuários, traços e produções culturais se sobressaiam na sociedade majoritária.

\subsection{Línguas de Sinais: resistência surda no campo educacional}

Quando as propostas da história da educação de surdos são analisadas, se sobressaem dois conjuntos de enunciados entremeados nas relações de poder e saber em torno do surdo e da língua que o mesmo deve adquirir, a saber, as línguas de modalidade oral-auditiva e as línguas de modalidade visual-motora. E, mesmo que essas relações se façam presentes na área da educação o que menos esteve em voga, em boa parte das discussões, foram os processos de ensino-aprendizagem envolvendo as diferentes disciplinas do conhecimento, pois a 
"autorização" do uso de uma língua, em detrimento de outra, foi a pauta que predominou - e ainda predomina, mesmo que em menor grau - na educação de surdos.

Antes de me deter nas propostas mais consistentes e amplamente disseminadas sobre a educação de surdos, para contextualizar, destaco que a percepção positiva acerca do surdo na Antiguidade ocorreu com a civilização egípcia, diante da crença do surdo ser um mediador entre os deuses e os faraós. Posteriormente, em diferentes épocas, alguns nomes são citados como pessoas que mencionaram a possibilidade comunicativa e de aprendizagem dos surdos, como exemplo destaco: o filósofo Sócrates que considerou a possibilidade comunicativa por meio das mãos, cabeça e do restante do corpo pelos surdos; Bartollo della Marca (1314-1357) que afirmava que os surdos poderiam aprender tanto por meio das línguas orais quanto das línguas de sinais; e Girolano Cardano (1501-1576) que mencionava que o surdo não precisava do uso da oralidade para aprendizagem da leitura e escrita (CARVALHO, 2013).

No entanto, diferentemente da civilização egípcia e dos nomes supracitados, a situação dos surdos foi marcada, na maioria das vezes, pela exclusão baseada na exaltação da fala oral como "legítima" forma de comunicação humana. O filósofo Aristóteles, foi um dos exemplos mais influentes nesse sentido, ele declarava a incapacidade de raciocínio dos surdos em decorrência da suposta falta de desenvolvimento da linguagem. E, inspirados pelos gregos, os romanos "também viam o surdo como um ser demasiado imperfeito para pertencer a uma sociedade que perseguia a perfeição física e intelectual” (CARVALHO, 2013, p. 11).

De forma geral, os surdos em diferentes civilizações foram tratados de forma negativa e punidos por serem pessoas que fugiam dos padrões de normalidade estabelecidos e foram, inclusive, afogados, jogados do alto dos rochedos, rejeitados, considerados como incapazes e desprovidos de razão perante a sociedade ouvinte. Sacks define esse longo período como uma calamidade:

[...] incapazes de desenvolver a fala, e, portanto "mudos", incapazes de comunicarse livremente até mesmo com seus pais e familiares, restritos a alguns sinais e gestos rudimentares, isolados, exceto nas grandes cidades, até mesmo da comunidade de pessoas com o mesmo problema, privados de alfabetização e instrução, de todo conhecimento do mundo, forçados a fazer trabalhos mais desprezíveis, vivendo sozinhos, muitas vezes à beira da miséria, considerados pela lei e pela sociedade como pouco mais do que imbecis - a sorte dos surdos era evidentemente medonha. (1998, p.27).

Porém, os surdos oriundos de famílias nobres se encontravam em posições mais favoráveis, pois as famílias realizavam a educação de seus filhos com auxílio de tutores. Estes tinham como objetivo ensinar a oralidade e a escrita, e em seus métodos alguns lançavam mão do uso da fala, escrita, alfabeto manual e alguns sinais. 
Dentre as primeiras iniciativas mais consolidadas sobre a educação de surdos, vários nomes estão diretamente ligados com a Igreja Católica. Carvalho (2013) cita que na Idade Média John Beverley, Arcebispo de York, foi o responsável pelo ensino da oralidade a um surdo contrapondo os preceitos de Aristóteles. E, posteriormente, já no século XVI, o monge Pedro Ponce de León se tornou o primeiro professor de surdos, desenvolveu um alfabeto manual e seu trabalho serviu de base para outros educadores, contribuindo também para a quebra do paradigma aristotélico. De acordo com Lodi (2005, p. 411):

Embora seja reconhecido e enfatizado em seu trabalho o ensino da fala aos surdos, o foco de sua educação era a linguagem escrita, pois, até o final desse século, acreditava-se que à escrita cabia a chave do conhecimento, ou seja, ela era tida como a natureza primeira da linguagem; a fala era apenas um instrumento que a traduzia. À escrita, fora atribuído, assim, um signo de poder.

Após León, outros educadores começaram a se dedicar à educação de surdos. Alguns utilizavam somente métodos orais, outros mesmo que tivessem como intuito a oralidade e/ou a escrita das línguas majoritárias, em seus métodos utilizam recursos visuais e a datilologia, e os métodos atribuídos como gestuais também ensinavam a oralidade. Dessa forma, a separação rigorosa entre os métodos oral e o gestual configura-se mais como uma ênfase dos discursos contemporâneos, do que uma delimitação que ocorria entre os educadores e as estratégias que os mesmos empregavam (CARVALHO, 2013).

A partir do século XVIII, na França, dentro de uma perspectiva religiosa que questionava o fato dos surdos não terem acesso às Palavras de Deus e o direito à confissão, o abade francês Charles Michel de L’Épée, ao se tornar o responsável pela educação de duas meninas surdas gêmeas, que se comunicavam pela modalidade visual-motora, desenvolveu um ensino pautado nesse tipo de modalidade comunicativa. Ao ter contato com outros surdos parisienses e a comunicação utilizada pelos mesmos, fundou a primeira escola pública para surdos do mundo, “L'Institution Nationale de Sourds-muets de Paris”. L’Épée se engajou no aprendizado dos sinais da língua que os surdos utilizavam e criou outros sinais, os chamados Sinais Metódicos, para suprir, aparentemente, a ausência de palavras e expressões equivalentes entre a língua de sinais e a língua francesa. Esta, na época, era considerada como uma língua que tinha uma gramática que gozava de status superior às demais línguas (LODI, 2013).

Na obra "La véritable maniére d'instruire les sourds et muets confinée par une longue expérience" de 1784, cujos excertos constam em Carvalho (2013, p. 19), L’Épée explica que:

Ensinar surdos é menos difícil do que normalmente se supõe. Apenas temos que introduzir nas suas mentes através dos olhos o que tem sido introduzido nas nossas próprias mentes através dos ouvidos. Estas duas avenidas estão sempre abertas, cada 
uma levando ao mesmo ponto; desde que não se desviem para a direita ou para a esquerda, seja qual for a nossa escolha.

Com o reconhecimento do trabalho realizado e a formação de outros educadores de surdos, as incursões do abade L’Épée favoreceu o surgimento de outras escolas na França e outros países Europeus, mesmo após sua morte, pois seu legado ficou a cargo de RochAmbroise Cucurron, o abade Sicard. Este contou com a colaboração de alguns alunos surdos que se tornaram répétiteurs e logo depois professores, como Jean Massieu e outros que além de atuarem no próprio Instituto, foram responsáveis pela disseminação da educação de surdos em outros continentes. Como, por exemplo, Laurent Clerc, que em 1816 foi para os Estados Unidos a convite de Thomas Hopkins Gallaudet, e Eduard Huet que veio para atuar no Brasil, a partir de 1855, e posteriormente no México.

Assim, os surdos se tornaram público-alvo de institutos, escolas e asilos específicos e voltados para a possibilidade de desenvolvimento dos mesmos, a partir da aquisição da leitura e escrita das línguas orais, do acesso ao conhecimento e da cultura das pessoas ouvintes. Esse movimento que possibilitava a educação coletiva de surdos favoreceu o contato surdo-surdo e o inevitável uso das línguas de sinais, mesmo que tais línguas não estivessem presentes em sua totalidade no processo de ensino-aprendizagem, elas faziam parte de diversas situações comunicativas.

Ao terem acesso à educação os surdos tiveram a oportunidade de mostrar outra visão sobre o que a sociedade havia construído sobre eles, conforme afirmou Laurent Clerc:

\footnotetext{
Quem nada tem, nada perdeu, quem nade perdeu, nada tem a lamentar. Ora, os surdos que nunca ouviram nem falaram nunca perderam nem a audição nem a fala e, por consequência, não podem lamentar nem uma nem outra. Ora, quem nada tem a lamentar não pode ser infeliz, assim os surdos-mudos não são nem podem ser infelizes. Além disso, é uma grande consolação para eles, poder substituir o ouvido pela escrita e a fala pelos gestos. (BERTHIER, 1873 [CARVALHO, 2013]).
}

Dessa forma Clerc, mesmo em outra época, exprime um enunciado que apresenta semelhanças aos enunciados proferidos por outros surdos, como os que foram exemplificados nos capítulos anteriores da presente pesquisa, sobre a percepção de si e da surdez como uma diferença que renuncia a negatividade.

O encontro surdo-surdo para além dos muros institucionais também se tornaram possíveis em função da organização e promoção de banquetes de surdos, durante o século XIX, apontando para o estabelecimento inicial do movimento com expressividade política e cultural. Esses banquetes eram ofertados por Ferdinand Berthier, que foi professor da 
Institution Nationale de Sourds-muets de Paris e o primeiro autor surdo que escreveu sobre a história da educação de surdos. De acordo com Carvalho (2013, p. 133):

\begin{abstract}
Os banquetes eram locais onde se celebrava a língua gestual, onde se debatiam assuntos ligados à educação de surdos e outros problemas que afetavam a comunidade surda. Também várias manifestações culturais tinham lugar nestes banquetes como a poesia em língua gestual, teatro, discursos, entre outras. Estes eventos foram divulgados por toda Europa já que Paris, nessa época, recebia vários artistas surdos nacionais e estrangeiros, na Academia Nacional de Belas Artes de Paris, que participavam nestes banquetes e, quando regressavam às suas cidades ou países de origem, organizavam reuniões semelhantes. Foi nestes banquetes que se sentiu a necessidade de começar a desenhar a criação de uma associação de surdos e assim, em 1838, é criada a primeira associação de surdos do mundo, a "Sociedade Central de Assistência e Educação dos Surdos-Mudos", que teve Berthier como primeiro presidente.
\end{abstract}

Esse período representa, segundo Sacks (1998), a emergência dos surdos no contexto do mundo civilizado, pois os mesmos deixaram de ser negligenciados e começaram a ocupar posições que antes eram consideradas inconcebíveis.

Porém, paralelamente ao processo considerado emancipatório, outras correntes compostas por defensores que se baseavam nos estudos e avanços da medicina, e no desenvolvimento de recursos materiais de amplificação sonora, também propagavam os resultados obtidos na educação de surdos. Como exemplo, cito Thomas Braidwood, na Inglaterra, e Samuel Heinicke, na Alemanha, que propunham uma educação que mesmo fazendo uso de diferentes metodologias tinha como finalidade desenvolver a língua oral.

Heinicke acreditava que era somente aprendendo a fala articulada que a pessoa surda conseguiria uma posição na sociedade ouvinte. Usava máquinas de fala para demonstrar a posição apropriada dos órgãos vocais para articulação e associava a pronúncia de vários sons vocálicos com certos sabores. (PEREIRA, 2011, p. 9).

No final do século XIX, em 1880, no II Congresso Internacional de Ensino de Surdos, em Milão, o grupo de educadores ouvintes excluiu os educadores surdos da votação e determinou como deveria ser a educação de surdos em todo o mundo. Houve a ratificação do emprego dos métodos orais, como os desenvolvidos por Braidwood e Heinicke, e proibidos os métodos que de alguma forma faziam uso das línguas de sinais, como o métodos baseados na proposta de L’Épée.

Inicia-se assim, uma filosofia educacional denominada como "Oralismo". Tal filosofia se baseava no uso da língua oral como forma de "recuperação" do surdo e não permitia o uso da língua de sinais tanto no ambiente escolar quanto no ambiente familiar (QUADROS, 1997). Nessa proposta houve a proibição oficial das línguas de sinais em todas as instituições que se dedicavam ao ensino de surdos em diferentes países. Conforme complementa Pereira (2011, p. 9), “mesmo reconhecendo que no método oral, os alunos surdos recebiam uma 
educação inferior, os defensores do oralismo acreditavam que, sendo a surdez medicamente incurável, as pessoas surdas deveriam falar a fim de se tornarem normais".

Mas enunciados denunciam que a motivação para tal decisão não estava pautada apenas nas crenças dos defensores do oralismo. Alguns autores, como Sacks (1998) e Skliar (2004), ressaltam que essa decisão estava relacionada mais aos interesses políticos, econômicos, religiosos e filosóficos da época, do que aos interesses, propriamente, educacionais. Segundo Skliar:

\begin{abstract}
A Itália ingressava num projeto geral de alfabetização e, deste modo, se tentava eliminar um fator de desvio linguístico - a língua de sinais -, obrigando também as crianças surdas a usar a língua de todos; por outra parte, o Congresso legitimava a concepção aristotélica dominante, isto é, a ideia de superioridade do mundo das ideias, da abstração e da razão - representado pela palavra - em oposição ao mundo do concreto e do material - representado pelo gesto; por último, os educadores religiosos justificavam a escolha oralista, pois se relacionava com a possibilidade confessional dos alunos surdos. (2004, p.78).
\end{abstract}

Até final dos anos 1960, o oralismo foi recebido como norma no processo de educação dos sujeitos surdos. Estes se viram em meio a práticas clínicas que começavam com a criação e uso de diferentes tipos de exame para diagnóstico da surdez, segundo Foucault (2013c, p.177), “o exame combina as técnicas da hierarquia que vigia e as da sanção que normaliza. É um controle normalizante, uma vigilância que permite qualificar, classificar e punir". Portanto, sendo o surdo qualificado e classificado por tipos de surdez e níveis de perda auditiva, iniciaram-se as práticas corretivas, tanto no ambiente clínico quanto no educacional, pois o currículo escolar regular foi substituído pela reabilitação da audição e da fala, com práticas desempenhadas também pelos educadores. E nesse processo, muitos surdos foram punidos, inclusive fisicamente, por apresentarem dificuldades nas atividades que focavam no desenvolvimento da oralidade. Tais punições consistiam em ridicularizações públicas, tapas nas mãos quando os alunos tentavam usá-las para se expressarem e até mesmo o confinamento dentro de armários e porões, como ocorria no Reino Unido (KYLE, 2009).

A função da escola se encaixou em um modelo clínico-terapêutico da surdez, pois houve uma ênfase no déficit biológico, na patologia, e no estabelecimento da relação entre desenvolvimento cognitivo e a aquisição da língua oral pelos surdos (SKLIAR, 2004). Neste mesmo sentido, Skliar (2004) baseado em outros autores, cita que ao transitarem do âmbito da pedagogia para o da medicina, os surdos estavam inseridos dentro de um processo de medicalização da surdez:

Medicalizar a surdez significa orientar toda a atenção à cura do problema auditivo, à correção de defeitos da fala, ao treinamento de certas habilidades menores, como a leitura labial e a articulação, mais que interiorização de instrumentos culturais significativos, como a língua de sinais. E significa também opor e dar prioridade ao 
poderoso discurso da medicina frente à débil mensagem da pedagogia, explicitando que é mais importante esperar a cura medicinal - encarnada atualmente pelos implantes cocleares - que compensar o déficit de audição através de mecanismos psicológicos funcionalmente equivalentes. (SKLIAR, 2004, p. 79).

A disciplina escolar, que se aproximava muito da disciplina clínica, que o surdo esteve sujeito propiciava a fabricação de corpos dóceis e úteis na vida adulta, já que "a disciplina aumenta as forças do corpo (em termos econômicos de utilidade) e diminui essas mesmas forças (em termos políticos de obediência)" (FOUCAULT, 2013c, p. 133). E tal disciplina se tornava evidente não apenas nas diversas atividades realizadas, mas também na arquitetura, nos espaços e nos dispositivos materiais utilizados.

A escola de surdos era dotada de elementos que buscavam ao máximo a normalização perante o ideal ouvinte e dispunha de inúmeros aparatos que facilitassem tal processo, como tablados, espelhos, aparelhos de amplificação sonora, instrumentos, máquinas que visavam o estímulo auditivo e paredes ou portas com vidro para que se mantivesse a vigilância constante, como forma de garantia que a língua de sinais não se fizesse presente nos espaços.

Tal organização estrutural nas escolas de surdos remete ao que Escolano (2001) menciona sobre a arquitetura escolar, segundo o autor, essa se constitui:

[...] por si mesma um programa, uma espécie de discurso que institui na sua materialidade um sistema de valores, como os de ordem, disciplina e vigilância, marcos para aprendizagem sensorial e motora e toda uma semiologia que cobre diferentes símbolos estéticos, culturais e também ideológicos. Ao mesmo tempo, o espaço educativo refletiu obviamente as inovações pedagógicas, tanto em suas concepções gerais como nos aspectos mais técnicos. (ESCOLANO, 2001, p. 26).

Entretanto, a disciplina com ênfase na oralidade condicionada aos surdos aos poucos revelava resultados insatisfatórios e os estudos realizados sobre filhos surdos de pais surdos que usavam a língua de sinais, traziam dados que apontavam as diferenças no desempenho acadêmico entre os mesmos. De forma geral, se afirmava que os surdos filhos de pais surdos apresentavam melhor desenvolvimento em relação aos surdos privados da língua de sinais.

Quando se toma como premissa que o poder não pode ser localizado em um dado local ou nas mãos de alguém, que não pode ser apropriado e que, na verdade, circula entre os indivíduos (FOUCAULT, 2004), as construções discursivas que valorizam o oralismo começavam a perder força frente às construções, em âmbito acadêmico, que afirmavam a ineficácia do ensino oral para maioria dos surdos. Somado a esses enunciados que se distanciavam da perspectiva oralista, haviam os enunciados que eram produzidos pelos próprios surdos que resistiam aos processos de normalização. 
Essa resistência pode ser representada quando se considera que as línguas de sinais, apesar de reprimidas, não foram excluídas da comunicação espontânea entre os surdos, principalmente, nas situações em que os mesmos estavam longe dos olhos dos que os vigiam durante a infância, no contexto escolar e familiar (ouvinte), e a partir da adolescência, no encontro com outros surdos fora das instituições escolares.

Paulatinamente alguns sinais da língua de sinais foram incorporados na educação de surdos, dentro de uma proposta denominada como "bimodalismo". No entanto, a ênfase nessa proposta ainda era a aquisição da língua oral e a busca da normalidade de acordo com o padrão ouvinte. Os sinais da língua de modalidade visual-motora eram utilizados, concomitantemente, com a oralidade e a estrutura gramatical priorizada era a da língua oralauditiva. Somada a essa prática, eram empregados outros recursos visuais como imagens e desenhos, pistas orais e a datilologia para suprir os elementos que não eram correspondentes entre uma língua e outra, localizando essa proposta dentro da filosofia da "Comunicação total", que defendia o desenvolvimento comunicativo.

Porém, Ciccone (1996), no prefácio da $2^{\mathrm{a}}$ edição do livro "Comunicação total: introdução, estratégias a pessoa surda", em defesa da Comunicação total na educação de surdos, alerta sobre o uso do "bimodalismo" nessa filosofia:

\footnotetext{
[...] Ocorre que temos sido questionados sobre a questão do uso de uma variante bimodal. A tal respeito, cabe relembrar, já tratávamos do assunto em conteúdos da primeira edição, quando esclarecíamos que entendemos o bimodalismo como técnica, cujas alternativas podem contar com variados tipos de recursos. E, quanto a isto, nesta oportunidade, cabe a informação de que desde o final do ano de 1987 já entendíamos, em nosso Modelo Brasileiro, que o uso de um pidgin sinalizado simultâneo à fala oral mais atrapalha do que ajuda num bimodalismo, que dele quisesse se servir sistematicamente.
}

O bimodalismo pode ser identificado como uma proposta também baseada na normalidade ouvinte, pois, além de desestruturar, gramaticalmente, as línguas de sinais e as línguas orais (QUADROS, 1997), o surdo era percebido dentro da perspectiva da deficiência e da necessidade de desenvolver habilidades comunicativas sejam elas quais forem no contato com os ouvintes.

No entanto, a filosofia da "Comunicação total", mesmo sendo criticada em algumas técnicas utilizadas, foi avaliada dentro de uma perspectiva mais positiva ao ser localizada em um contexto que contempla a transição entre a proibição das línguas de sinais e o reconhecimento e aceitação das mesmas na educação de surdos.

Somente com a ampliação dos estudos linguístico das línguas de sinais, iniciados em 1960, com a organização e consolidação das comunidades e associações de surdos, bem como 
com os estudos que evidenciavam os aspectos negativos do "oralismo" e do "bimodalismo" na educação, que os surdos se viram em meio à possibilidade de se distanciarem dos enunciados centrados no modelo clínico da surdez e de aquisição da oralidade.

$\mathrm{Na}$ fase atual da educação de surdos, a filosofia do "Bilinguismo" surge em países nórdicos, a partir da década de 1980, e no Brasil a partir da década de 1990, sob uma base discursiva que valoriza as línguas de sinais e as comunidades e culturas surdas.

A proposta bilíngue está pautada na aquisição, uso e ensino das línguas de sinais, como L1, e na aquisição da modalidade escrita das línguas oral-auditivas, como L2. A modalidade oral se torna opcional e, geralmente, é delegada para profissionais da área da saúde, cujo trabalho se dá fora do horário escolar, no caso do Brasil. Nessa proposta os alunos surdos têm a oportunidade de acesso aos currículos e conteúdos escolares como qualquer outro aluno. E pela primeira vez, na história da educação de surdos, o desenvolvimento da oralidade, se torna uma opção e não uma imposição.

O bilinguismo também remete a outra inovação frente às propostas anteriores, pois contempla a construção discursiva que compreende o surdo no contexto da diferença não apenas linguística, mas também cultural, e valoriza o contato surdo-surdo no ambiente escolar.

A língua de sinais passa a ser considerada como primordial em contraposição aos preceitos que, outrora, subjugavam a condição humana do "ser" surdo. Essa nova perspectiva pode ser identificada na maioria dos enunciados que tratam do bilinguismo para surdos em diferentes países. Como exemplo, citarei dois enunciados que foram proferidos no contexto da discussão sobre a educação bilíngue em países nórdicos, mas que também são comuns entre os defensores do bilinguismo no Brasil:

\footnotetext{
[...] a língua de sinais enfatiza seu significado fundamental para o desenvolvimento da língua, para o pensamento e habilidades de comunicação dos estudantes, para suas personalidades, para sua capacidade de adquirir conhecimento e sua participação tanto na cultura sueca [a autora tratava do bilinguismo da Suécia, mas remetendo ao nosso país pode-se substituir por "cultura brasileira"] como na cultura dos surdos. (SVARTHOLM, 2009, p. 18).

O profundo conhecimento da língua de sinais e o desenvolvimento de uma estrutura profunda bem formada dessa língua são cruciais para as capacidades cognitivas: o pensamento conceitual e abstrato. Boas habilidades de expressar sentimentos, emoções, pensamentos, conceitos, em estilos muito diferentes, desde a expressão de humor, expressões artísticas até disputas argumentativas [...]. (JOKINEN, 2009, p. $105)$.
}

Em ambos os enunciados, verifica-se a alusão de elementos que extrapolam as questões de aquisição pura e simples de uma língua, e que remetem à cultura e a expressão dos surdos em termos discursivos e artísticos. 
A proposta bilíngue passa a ser denominada também como bicultural, quando se considera a cultura surda e a cultura ouvinte, ou multicultural quando se problematiza as questões de caráter diferenciador e intrínseco às diferentes culturas no contexto da pósmodernidade.

O espaço escolar se torna um local profícuo para o contato, propagação e produção cultural dos surdos, conforme afirmam Lopes e Veiga-Neto (2006), a credibilidade sobre a escola e o que nela se aprende, encontra-se acima de quaisquer suspeitas e como, geralmente, ela é a primeira instituição frequentada pelas crianças fora do ambiente familiar, na escola, além da convivência, promove-se a autoidentificação entre os surdos.

Porém, muitos profissionais propagam enunciados que além de omitir as possibilidades de produções e trocas culturais próprias das comunidades surdas, afirmam que quando a criança surda tem acesso à língua de sinais como primeira língua, não desenvolverá e nem usará outra língua. Ou seja, a aquisição de uma língua estaria condicionada a "subtração" de outra, entretanto, tal ideia se opõe a perspectiva "aditiva" de enunciados como os de Quadros:

Em uma perspectiva "aditiva", saber mais línguas apresenta vantagens tanto no campo cognitivo, quanto nos campos político, social e cultural. As crianças são estimuladas a conhecer diferentes formas de organizar o mundo através das diferentes línguas em diferentes contextos culturais. (2005, p. 27).

Muitas famílias ao descobrirem que tem um filho surdo são aconselhadas por alguns médicos e fonoaudiólogos, que fundamentam suas propostas numa perspectiva do ouvintismo, para realizarem o processo de reabilitação do seu filho por meio do AASI, do IC e de terapia fonoaudiológica, e o contato com a comunidade surda e a língua de sinais nem sempre são cogitados.

Uma mãe de um surdo que foi oralizado oferece um depoimento nesse sentido no trabalho de Botelho:

\footnotetext{
A língua de sinais era contra-indicada pela fonoaudióloga que o atendia, e pela família, que seguia sua orientação: Se deixasse, ele usaria bastante gesto \{...\}Chegava a ponto de falar: Baixa o braço, não gesticula não! Fala o que cê deu conta de falar \{...\}. Gestos normais igual um ouvinte faz, não é cobrado que não faça. Gestos normais igual eu tô dizendo assim, ou se aponta ali, o que um ouvinte faz e que o deficiente auditivo for fazer, tudo bem, é aceitável. (2009, p. 151, grifo do autor).
}

Tais práticas podem ser localizadas como enunciados que se ramificam do discurso pautado na deficiência e na normalidade sociocomunicativa ouvinte, pois a língua de sinais ao não ser cogitada entre esses profissionais, não podem fazer parte da perspectiva "aditiva" 
mencionada por Quadros (2005), que considera a aquisição natural de uma língua, para o posterior ou simultâneo aprendizado de outra língua. E mesmo que algumas mães saibam da existência da língua de sinais, inicialmente, apostam nas recomendações realizadas por profissionais que se dedicam ao processo de reabilitação da surdez e deixam a língua de sinais como uma possibilidade futura, que só será posta em prática, se a oralidade da língua portuguesa não der certo.

Nesse sentido, duas mães se referem aos preceitos da instituição onde seus filhos foram implantados e suas opiniões pessoais sobre o uso da língua de sinais.

[...] por ser um centro de referência, ele só implanta criança hoje até dois anos de idade, ta. E realmente o critério que eles usam [...] é que as crianças não tenham familiaridade com a Libras, porque vai confundir a criança, por exemplo, a gente ta aqui entre a gente o Açaí [esse é nome fictício adotado pela pesquisadora para o filho dessa mãe], vocês aqui brincando ensinam pro Açaí, o 5, que é mais ou menos parecido com isso, que eu não sei fazer, perdão, então Açaí começa a contar [oralmente]: 1, 2, 3, 4 quando é no 5 ele faz em Libras... então, você já imaginou a confusão que ocorre na cabeça da criança? (REZENDE, 2012, p. 136).

Na minha opinião assim, por que eu não quis que Tucumã [esse é nome fictício adotado pela pesquisadora para o filho dessa mãe] aprendesse sinais agora? Porque para eles que são deficientes auditivos, sinais seria o caminho mais fácil e eu não sei se depois que ele aprendesse sinais ele queria ter o trabalho de ser oralizado, então eu penso, eu vou deixar que ele seja oralizado, aí quando ele já tiver oralizado, aí sim eu quero que ele aprenda sinais. Aí ele vai poder escolher se ele quer falar ou quer usar sinais, quer conviver com ouvintes ou com surdos. (REZENDE, 2012, p. 138).

Além desses dois trechos, Rezende (2012), pesquisadora e militante na comunidade surda, faz uma análise de vários outros enunciados, tendo como aporte teórico a perspectiva de Foucault. Em seu texto a autora localiza a regularidade de enunciados entre as mães de crianças surdas que foram - ou seriam - submetidas à cirurgia de IC, entre profissionais da área da saúde que trabalham diretamente com IC, diagnóstico e reabilitação da surdez e em alguns artigos publicados em jornais locais da região de Manaus, local em que a pesquisa foi realizada. A consolidação da normalidade sociocomunicativa ouvinte encontra-se evidenciada no texto de Rezende e a família foi apontada como uma instituição que além de incorporar essa normalidade, estabeleceram estratégias de vigilância em outras famílias que estavam passando pelo processo que envolve o IC.

Situação semelhante ocorre no discurso pedagógico, um conjunto de enunciados remete ao uso da língua de sinais numa proposta bilíngue e mesmo que vários profissionais da área da educação apontem a importância do uso da mesma, deixam transparecer uma preocupação exacerbada sobre a necessidade do desenvolvimento da língua majoritária do país. No caso do Brasil, usam a Libras com o objetivo de desenvolver a Língua Portuguesa e 
as dificuldades que o aluno surdo pode apresentar, nesse último processo, se tornam alvo de inúmeras pesquisas no meio acadêmico e motivo de preocupação e cobrança sobre os professores responsáveis por essa educação e os outros profissionais envolvidos com o contexto escolar.

A prioridade no desenvolvimento da Língua Portuguesa se torna mais evidente quando: se analisa os currículos escolares das escolas bilíngues para surdos, das escolas bilíngues regulares, ou ainda nas escolas regulares inclusivas; se constata a pouca ou até mesmo a ausência de proficiência em língua de sinais por parte dos educadores, da gestão e dos demais funcionários, somando-se a falta de contato com as comunidades surdas e participação de surdos adultos no contexto escolar; se observa também a pouca oferta de acesso às produções culturais dos surdos. Esses são alguns elementos que permitem a aproximação dos enunciados que constroem os saberes sobre o bilinguismo, aos enunciados oriundos da perspectiva normalizadora pautada na sociedade majoritária.

Assim, Skliar cita que é:

[...] axiomático que, ao mencionar o caráter bilíngue de um projeto educativo, seja reconhecido o direito que tem as crianças que usam uma língua diferente da língua majoritária de serem educadas na sua língua. Por isso, a materialização de uma educação bilíngue para surdos não é apenas uma decisão de natureza técnica, mas dever ser politicamente construída tanto quanto sociolinguisticamente justificada. (2009, p. 10).

No bilinguismo, depositam-se expectativas de desenvolvimento aos surdos que foram negadas nas propostas anteriores. Sá (2005), ao questionar a preferência de um surdo sobre as propostas educacionais que foram consolidadas historicamente, transcreve a seguinte consideração:

\footnotetext{
No oralismo os surdos cresciam fracos em Sinais, a oralização era perfeita mas não conheciam profundamente as palavras. Decoravam as palavras, mas não conheciam o que estavam falando. $\mathrm{O}$ surdo sofre há anos porque sempre foi imposto o Oralismo. A Comunicação Total deu um pouco mais de Língua de Sinais, mas as mãos ainda estavam muito confusas, muito trancadas... não combinava a fala com as mãos: era um problema... Imagino que agora, com o estudo do Bilinguismo, vai melhorar. As professoras vão respeitar o surdo, vai haver os direitos dos surdos. Na minha opinião o Bilinguismo é melhor porque o surdo vai ficar mais livre, vai poder se expressar, questionar, progredir, ir adiante. Vai ser melhor para ele, não haverá discriminação. (SÁ, 2005, p. 174).
}

Nas últimas duas décadas, há uma aposta discursiva sobre o bilinguismo na educação de surdos, no entanto, o discurso pautado na deficiência, na ausência, no problema, na necessidade de se adquirir a língua majoritária, seja ela na modalidade oral ou escrita, mesmo que tenha diminuído em termos de visibilidade e propagação, também se encontra em voga 
nas relações de poder e saber em torno da língua que o surdo deve adquirir, bem como no processo de conquista de espaço na sociedade, principalmente quando se considera o contexto acadêmico e o mercado de trabalho.

A disputa não cessou, o que houve foi um fortalecimento no cenário de resistência surda, e o direito de usar a língua de sinais, se tornou a principal pauta de luta. Os surdos, mais do que nunca, tem a oportunidade de se tornarem - e é isto o que eles têm feito - sujeitos do discurso e expressarem o que pensam e o que querem para sua educação e comunidade, e muitos ouvintes têm compartilhado com eles os mesmos pontos de vista.

Não obstante, destaco três enunciados que exemplificam o momento que vivemos na atualidade, pois todos foram proferidos no intervalo máximo de quatro anos, quando se tem como referência o ano em que concluí esta pesquisa, no caso, 2014.

Como primeiro exemplo cito o enunciado que se localiza no discurso da diferença linguística e cultural de uma mãe ouvinte, que tem duas filhas surdas, que coaduna com a valorização da língua de sinais: "Libras é o que une a família. A Libras para a família antes de ser um bem coletivo, antes de ser uma identidade cultural, antes de ser um bem linguístico para a humanidade, a Libras para a família deverá ser uma questão moral: não fazer o outro sofrer" (REZENDE, 2012, p.104).

Surdos oralizados, não usuários das línguas de sinais, também defendem seus interesses ao se posicionarem a favor do avanço da tecnologia sobre o AASI e IC. Isso se dá quando: afirmam o não pertencimento às comunidades surdas; reclamam à diferenciação em enunciados que generalizam que todos os surdos devem usar a língua de sinais e que os surdos têm muita dificuldade na aquisição de línguas na modalidade oral-auditiva; e sugerem que os surdos oralizados precisam se unir discursivamente. Conforme expressa Lobato $(2011)^{10}$ :

Olha, longe de mim lutar contra a Libras, mas sinceramente, não faria mal os
entusiastas respeitarem a existência de deficientes auditivos de outros graus que não
a anacusia (ausência total de audição) ou deficientes auditivos adquiridos, que
tiveram português como primeiro idioma. Tampouco, deveriam vender que surdez
incapacita alguém de aprender o idioma que for, porque isso faz com que os leigos
no assunto, por tabela, achem que déficit auditivo limita o intelecto também.
Ninguém é incapacitado de aprender português porque é surdo, apenas uma parte
considerável de surdos tem mais afinidade com a língua de sinais e ponto. [...]
Só que, a gente sabe, enquanto não tiver ninguém para avisar o mundo que
deficientes auditivos nem sempre nasceram surdos, que deficientes auditivos de
graus moderados, severos e até profundos podem ser plenamente oralizados e
alfabetizados em português, por aparelho auditivo, implante coclear, sistema BAHA
e/ou por fonoterapia, estudando em escola inclusiva ou até regular (meu caso!), a

${ }^{10}$ O texto completo de Lobato (2011) consta em: <http://desculpenaoouvi.laklobato.com/2011/10/26/por-que-eimportante-divulgar-a-existencia-dos-surdos-oralizados/> Acesso em: 07 jun. 2014. 
sociedade vai continuar ouvindo apenas aqueles que divulgam a língua de sinais e que tentam vendê-la como sinônimo de deficiência auditiva.

$\mathrm{Na}$ boa, ninguém precisa omitir que o outro existe para advogar em causa própria. Portanto, que os Surdos Oralizados sejam divulgados à exaustão.

Por fim, há o enunciado que se aproxima tanto da perspectiva que defende a língua de sinais quanto o uso do IC e processos de desenvolvimento da oralidade. No caso, consta abaixo o relato de uma mãe de uma criança surda que, primeiramente, foi implantada e depois foi matriculada em uma escola para surdos que trabalha dentro da proposta bilíngue e conta com a atuação de profissionais surdos e ouvintes. Para contextualizar, o presente trecho foi retirado de um texto que Schaade $(2013)^{11}$ tematiza o fato de ter completado um ano de contato com a língua de sinais:

[...] A Libras é uma língua que não prejudica em absolutamente nada a oralização da criança. Em um ano ele não entendia nada quando eu falava (oralmente) com ele. Hoje através da Libras conversamos, contamos histórias, o G. me conta sobre a rotina da escola, sabe contar até 10, sabe todas as cores, consegue formular frases, pedir as coisas, brigar, inventar histórias, enfim, tudo que é esperado de uma criança de 3 anos e meio ele sabe. Quanto a audição recomeçamos do zero, mas está indo muito bem, agora acredito que ele está com a programação certa porque apesar do pouco tempo ele tem respondido muito melhor aos sons. O fato do G. saber Libras tem ajudado também na terapia.

Tais exemplos, quando retomo o processo de formação dos surdos dentro de propostas bilíngues que também sejam multiculturais, têm contribuído para que os conjuntos de enunciados pautados na diferença linguística e cultural se constituam como saberes que se propagam, de forma mais profícua, nos espaços escolares, mas com perspectivas de permeabilidade em outros campos.

A seguir, em continuação a fundamentação teórica tomarei como parâmetro a efetivação da língua de sinais no campo discursivo, por meio do reconhecimento da Língua Brasileira Sinais no meio acadêmico e legislativo, especialmente, no contexto brasileiro.

\subsection{Libras: normatividades e propagação discursiva}

Na presente seção abordarei alguns estudos realizados que tiveram como premissa as características linguísticas das línguas de sinais agregando-se e fortalecendo o conjunto de

\footnotetext{
${ }^{11}$ O texto completo de Shaade (2013) consta em:

<http://filhosespeciaispaisabencoados.blogspot.com.br/search/label/Libras > Acesso em: 08 jun. 2014.
} 
enunciados pautados no discurso da diferença linguística e cultural, e que ao se efetivarem dentro da normatividade legal favoreceram a disseminação de saberes sobre essas línguas.

Como já citei no capítulo "A cultura surda no contexto dos Estudos Culturais" e reiterei na seção anterior, a maioria dos enunciados que se opunha a consideração da língua de sinais como língua, de forma geral, estava vinculada à normalidade sociocomunicativa baseada no ouvinte. Consequentemente, boa parte dos estudos linguísticos realizados, durante muito tempo, se dedicou apenas à análise e descrição de línguas de modalidade oral-auditiva.

Apesar das línguas de sinais não terem sido alvos iniciais dos estudos sobre língua e linguagem, de acordo com Quadros e Karnopp (2004) estudiosos da área da linguística, como Chomsky e Saussure, apontam que o canal fonoarticulatório para expressão de uma língua foi uma convenção restritiva e que outros canais poderiam ser utilizados para expressar a capacidade linguística dos seres humanos. Nesse sentido, as línguas de sinais podem ser caracterizadas como línguas de modalidade diferente e como línguas naturais, pois:

[...] uma língua natural é uma realização específica da faculdade de linguagem que se dicotomiza num sistema abstrato de regras finitas, as quais permitem a produção de um número ilimitado de frases. Além disso, a utilização efetiva desse sistema, com fim social, permite a comunicação entre os seus usuários. (QUADROS; KARNOPP, 2004, p. 30).

Segundo Capovilla (2001), Wilhelm Wundt, da área da Psicologia Experimental, foi a primeira pessoa do meio acadêmico a reconhecer o caráter autônomo da língua de sinais e do surdo como alguém que tem cultura própria. No entanto, a comprovação efetiva que as línguas de sinais eram línguas naturais ocorreu somente a partir dos estudos realizados sobre a American Sign Language (ASL) por William C. Stokoe, na década de 1960.

Stokoe comprovou que os sinais eram símbolos abstratos complexos e estruturados que poderiam ser analisados por partes tendo como princípio o estabelecimento de parâmetros como a configuração de mão, a localização (ponto de articulação) e o movimento, além de identificar as quantidades e as possibilidades de diferenciação presentes nos sinais de acordo os parâmetros citados.

Inicialmente, o estudo realizado pelo pesquisador sofreu resistência na renomada instituição de surdos em que atuou. Em Sacks (1998, p. 155) consta o seguinte comentário proferido por Stokoe:

A publicação em 1960 [de Sign Language Structure] provocou uma reação local curiosa. Com exceção de Dean Detmold e um ou dois colegas, todo o corpo docente do Gallaudet College rudemente criticou-me, criticou a linguística e o estudo da comunicação por sinais como uma língua [...]. Se a recepção do primeiro estudo linguístico da língua de sinais da comunidade surda foi gélida em casa, ela foi criogênica em grande parte na educação especial - naquela época uma corporação fechada, tão hostil à língua de sinais quanto ([era]) ignorante da linguística. 
Posteriormente a esse estudo, outros pesquisadores acrescentaram os parâmetros orientação e expressões não-manuais e houve a expansão de pesquisas sobre as línguas de sinais em diferentes países, inclusive no Brasil, tomando como fundamentação o que fora publicado sobre a ASL. Caso o leitor queira ter acesso, de forma pormenorizada, aos estudos sobre a Libras na área da linguística indico Ferreira-Brito (1995) e Quadros e Karnopp (2004).

Torna-se válido ressaltar que o registro do uso de língua de sinais ocorreu bem antes dos estudos realizados e das propostas e metodologias educacionais criadas para os surdos. Wilcox e Wilcox (2005) apontam dois registros que comprovam a existência das línguas de sinais naturais anteriores a existência das línguas de sinais contemporâneas como a ASL e a Libras. Um dos registros concentra-se, no final do século XVII, na língua de sinais utilizada na ilha de Marthas's Vineyard. Neste local, a taxa de incidência da surdez chegou ao nascimento de um surdo para cada 155 pessoas, mas tal proporção era maior ou menor de acordo com as cidades ou bairros da ilha.

Com o florescimento da comunidade surda em Martha's Vineyard, consolidou-se também a sua língua. Supõe-se que a língua sinalizada local foi baseada numa variedade regional da língua de sinais britânica. Rapidamente, ela teria se expandido por toda a ilha até quase todos os indivíduos, surdos ou ouvintes, fossem capazes de utilizar a língua de sinais de Vineyard. [...] a maioria da população ouvinte da ilha era bilíngue em inglês falado e em língua de sinais de Vineyard, a surdez não era vista como uma incapacidade. (WILCOX; WILCOX, 2005, p. 37).

Outra evidência sobre a existência de outra língua de sinais ocorreu por meio do livro intitulado “Observações de um surdo-mudo”, escrito pelo surdo Pierre Desloges em 1779 na França, sobre a língua utilizada pelos surdos que moravam em Paris. Provavelmente, esta foi a língua que o abade L'Épée teve contato, conforme descrevi no início do presente capítulo. No entanto, como o abade modificou a língua de sinais ao inserir gestos que representariam os aspectos próprios da língua francesa oral, como por exemplo, artigos, preposições, terminações verbais ou verbos auxiliares (WILCOX; WILCOX, 2005), foi esta "nova" Langue des Signes Française (LSF), influenciada por elementos das línguas orais, que serviram de base tanto para a ASL, quanto para a Libras, em decorrência da atuação dos surdos que dominavam a LSF nos EUA e no Brasil.

Não obstante, independentemente, das influências de cunho "artificial" ou "natural" entre as línguas orais e as línguas de sinais, e entre as línguas de sinais com outras línguas de sinais, diferentes comunidades surdas de todo o mundo engendraram línguas, de modalidade visual-motora, relacionadas às necessidades comunicativas locais, fato que contribuiu para impossibilidade da existência de uma única língua de sinais em todo o mundo. 
Como as distâncias geográficas desfavorecem o contato sociocomunicativo e cultural entre seus usuários, assim como ocorre com as línguas de modalidade oral-auditiva, cada comunidade surda, dos mais diversos países, desenvolveu sua própria língua de sinais que pode ou não estar, necessariamente, relacionada a outras línguas de sinais. Mas em processos distintos, na maioria das vezes, dos empregados historicamente no uso e desenvolvimento das línguas orais desses mesmos países como, por exemplo, ocorreu com a colonização e - ainda ocorre - com a imigração.

Dessa forma, menciono a British Sign Language (BSL) que surgiu de forma independente de qualquer outra língua sinalizada e não se relaciona à ASL. A LSF utilizada na França que historicamente influenciou a ASL e a Libras. E ao mesmo tempo temos a Libras que não se relaciona à Língua Gestual Portuguesa (LGP).

Porém, a LGP é utilizada em alguns países africanos que também foram colonizados por Portugal e empregam políticas a favor da Língua Portuguesa oral, em detrimento das diversas outras línguas orais presentes nesses países. Mas, paulatinamente, a LGP utilizada nesses países têm se diferenciado da língua dos surdos de Portugal, em decorrência do desenvolvimento de sinais próprios que emergem do encontro surdo-surdo e da influência cultural que estão imersos no cotidiano.

Além de origens distintas, as relações vivenciadas pelos surdos fazem com que alguns sinais sejam utilizados de forma diferente dentro de um mesmo país. Como ocorre no Brasil, por meio da análise da diversidade dos sinais regionais que constam em dicionários de Libras e nos vídeos propagados pelos surdos em sites da rede mundial de computadores, como o YouTube.

Quadros e Karnopp (2004) mencionam pesquisas realizadas sobre as diferenças entre as línguas de sinais e uma delas foi a que identificou que apenas 26,5\% dos sinais utilizados na ASL são iguais aos sinais da LSF, apesar destas línguas terem relação histórica. E outra pesquisa comprovou a incompreensão das línguas de sinais de outros países por parte dos surdos de 17 nacionalidades.

De forma complementar, ressalto que além dos estudos empreendidos sobre a Libras utilizada pelos surdos de nosso país, alguns pesquisadores afirmam a possibilidade de existência de outras línguas da mesma modalidade, como a Língua de Sinais Kaapor Brasileira (LSKB) utilizada pelos surdos das comunidades indígenas Kaapor do sul do estado do Maranhão e objeto de estudo da linguísta brasileira Lucinda Ferreira.

Outras pesquisas têm se dedicado ao mapeamento de sinais utilizados por surdos, de algumas aldeias indígenas, conforme apontam os estudos de Vilhalva (2012) que teve como 
foco a comunicação dos surdos índigenas do estado do Mato Grosso do Sul, e de Giroletti (2008) sobre os sinais Kaingang utilizados pelos alunos surdos que frequentavam uma escola indígena da aldeia Kaingang no município de Ipuaçu no estado de Santa Catarina. No entanto, os estudos são incipientes e ainda não afirmam o caráter estrutural linguístico dessas línguas, e a independência delas com relação a Libras.

Diante da exposição realizada, se torna evidente a propagação discursiva que atesta o status das línguas de sinais. E além dos enunciados nesse sentido ocuparem o espaço acadêmico com o teor de reconhecimento e divulgação, essas línguas são abordadas na legislação do Brasil e de outros países.

A Libras, apesar de ser um meio de comunicação utilizado há muito tempo no interior das comunidades surdas espalhadas por todo país, especialmente, nos grandes centros urbanos, foi reconhecida legalmente, em âmbito nacional, apenas em 24 de abril de 2002 pela Lei Federal n ${ }^{\circ} 10.436$ (BRASIL, 2002), na qual destaco o seguinte trecho:

Entende-se como Língua Brasileira de Sinais - Libras a forma de comunicação e expressão, em que o sistema linguístico de natureza visual-motora, com estrutura gramatical própria, constitui um sistema linguístico de transmissão de ideias e fatos, oriundo de comunidades de pessoas surdas do Brasil. (BRASIL, 2002).

Esta lei além de ser considerada discursivamente como um marco representativo das lutas e processos de resistência empreendidos pela comunidade surda brasileira nas relações de poder e saber estabelecidas na área da surdez, ela normatiza a Libras, como língua, e o caráter simbólico das comunidades surdas para o desenvolvimento da mesma.

É válido ressaltar que o texto da Lei ${ }^{\circ} 10.436$, além de ser objetivo, não prevê ações detalhadas decorrentes do reconhecimento da Libras no país. A lei cita de forma vaga o apoio ao uso e a difusão da Libras pelo poder público; o atendimento e tratamento na área da saúde aos denominados "portadores de deficiência auditiva"; a inclusão da Libras como parte dos Parâmetros Curriculares Nacionais (PCN), nos cursos responsáveis pela formação em fonoaudiologia e nos cursos de magistério e educação especial nos sistemas educacionais federal, estadual e municipal; e, afirma-se que a Libras não assume o caráter substitutivo da Língua Portuguesa na modalidade escrita.

A Lei aponta para alguns enunciados que podem ser localizados dentro da perspectiva da diferença linguística e cultural, abrindo precedentes para que não apenas profissionais da área da educação tenham contato com essa língua, mas também os profissionais da área da saúde. 
E mesmo que o uso da Libras tenha se dado bem antes de seu reconhecimento normativo, os surdos tomam a data de aprovação da lei, e poder simbólico conferido a mesma, como uma ocasião para comemorar o fato da língua ter sido oficializada e instaurar movimentos de reivindicação. Cito, como exemplo, a manifestação com esse viés no ano de 2012 quando a lei completou 10 anos e vários surdos aproveitaram o ensejo para se reunirem na sede do governo federal em Brasília - DF, em defesa da cultura surda e da educação bilíngue para surdos.

Dando continuidade a normatividade legal da Libras, em 22 de dezembro de 2005, foi

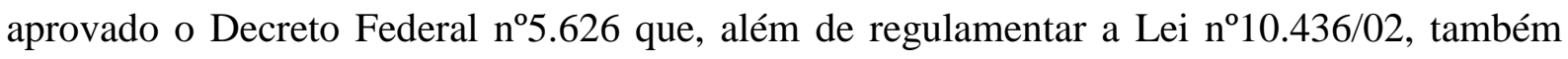
regulamentou o artigo $n^{\circ} 18$ da "Lei de Acessibilidade" no 10.098 (BRASIL, 2000) de 19 de dezembro de 2000.

Mesmo sendo anterior à lei de reconhecimento da Libras, a "lei de acessibilidade" já citava a necessidade da viabilização comunicativa das pessoas surdas, ao prever que "o Poder Público implementará a formação de profissionais intérpretes de escrita em braile, linguagem de sinais e de guias-intérpretes, para facilitar qualquer tipo de comunicação direta à pessoa portadora de deficiência sensorial e com dificuldade de comunicação" (BRASIL, 2000).

No que se refere, especificamente, ao Decreto $n^{\circ} 5.626 / 05$, este de forma mais detalhada que a Lei $\mathrm{n}^{\circ}$ 10.436/02 dispõe de vários aspectos que concernem a Libras e aos surdos, ao longo de nove capítulos que compreendem o total de 31 artigos que dispõe sobre: Quem são as pessoas surdas ou com deficiência auditiva; A inclusão da Libras como disciplina curricular; Formação do professor de Libras e do instrutor de Libras; O uso e difusão da Libras e da Língua Portuguesa para o acesso das pessoas surdas; A formação do tradutor e intérprete de Libras - Língua Portuguesa; A garantia do direito à educação das pessoas surdas ou com deficiência auditiva; A garantia do direito à saúde das pessoas surdas ou com deficiência auditiva; O papel do poder público e das empresas que detêm concessão ou permissão de serviços públicos, no apoio ao uso e difusão da Libras; e da Inclusão anual de dotações orçamentárias para viabilizar as ações previstas em cada capítulo.

No primeiro capítulo que aborda as "Disposições preliminares" destaco o trecho que pela primeira vez, em textos legislativos federais, se refere claramente ao "ser" surdo no sentido do discurso da diferença linguística e cultural:

Para fins deste Decreto, considera-se pessoa surda aquela que, por ter perda auditiva, compreende e interage com o mundo por meio de experiências visuais, manifestando sua cultura principalmente pelo uso da Língua Brasileira de Sinais - Libras. (BRASIL, 2005). 
Dessa forma, o decreto reitera e normatiza o surdo enquanto um sujeito que tem cultura e língua própria. Mas, no mesmo também consta a terminologia "pessoas com deficiência auditiva", contemplando as pessoas que apresentam perda auditiva e que nem sempre utilizam a língua de sinais ou se identificam com os traços culturais compartilhados nas comunidades surdas.

No capítulo que trata "Da inclusão da Libras como disciplina curricular”, destaco o texto que contribuiu para realização da presente pesquisa, pois nele consta a obrigatoriedade da Libras ser inserida, enquanto disciplina curricular, no ensino superior, conforme consta no artigo $3^{\circ}$ e no parágrafo $2^{\circ}$ :

A Libras deve ser inserida como disciplina curricular obrigatória nos cursos de
formação de professores para o exercício do magistério, em nível médio e superior, e
nos cursos de Fonoaudiologia, de instituições de ensino, públicas e privadas, do
sistema federal de ensino e dos sistemas ensino dos Estados, do Distrito Federal e
dos Municípios.

$\S 2^{\circ}$ A Libras constituir-se-á em disciplina curricular optativa nos demais cursos de educação superior e na educação profissional [...]. (BRASIL, 2005).

Tornar o ensino da Libras obrigatório normatizou as possibilidades de ouvintes que nunca tiverem contato com a língua de sinais dos surdos brasileiros, terem contato com a mesma e com o conjunto de enunciados que concernem a diferença linguística e cultural. Podendo abrir precedentes para desconstrução do conjunto de enunciados pautados na deficiência e normalidade ouvinte. Além disso, esse artigo inaugura um campo de atuação profissional aos surdos e ouvintes que têm como premissa a disseminação da língua de sinais.

No entanto, quando o texto contempla a obrigatoriedade em ter a disciplina apenas em cursos de licenciatura e fonoaudiologia e o caráter optativo em outros cursos, denota que os surdos são frequentadores e necessitam apenas dos serviços prestados nos espaços escolares e de terapia fonoaudiológica.

Outros artigos normatizam os preceitos que abordei na proposta da educação bilíngue para surdos e reiteram a opção de desenvolvimento de diferentes modalidades comunicativas dos surdos e das pessoas com deficiência auditiva. O ensino da Língua Portuguesa, no que concerne à escrita, foi delegado à escola e a oralidade ao profissional da área de fonoaudiologia, preferencialmente, no contraturno escolar.

De forma complementar o capítulo que trata da "Garantia do direito à educação das pessoas surdas ou com deficiência auditiva", proclama o direito dos alunos surdos da Educação Infantil e Ensino Fundamental I de frequentarem escolas e classes de educação bilíngue com professores também bilíngues. E o direito dos alunos surdos do Ensino 
Fundamental II, Ensino Médio e educação profissional de frequentarem escolas bilíngues ou escolas regulares com professores conhecedores da diferença linguística desses alunos e da atuação de tradutores e intérpretes da Libras-Língua Portuguesa. Bem como o acesso ao atendimento educacional especializado ofertado em turno distinto ao da escolarização.

O capítulo que aborda "A garantia do direito à saúde das pessoas surdas ou com deficiência auditiva" assevera ações de prevenção, diagnóstico, tratamento, atendimento e acompanhamento médico e fonoaudiológico especializado ou por equipe multiprofissional, e a reabilitação por meio de aparelhos de amplificação sonora para as pessoas surdas e pessoas deficientes auditivas que não fazem uso da Libras. Desse capítulo, destaco três aspectos:

VIII - orientações à família sobre as implicações da surdez e sobre a importância para a criança com perda auditiva ter, desde o nascimento, acesso à Libras e à Língua Portuguesa;

IX - atendimento às pessoas surdas ou com deficiência auditiva na rede de serviços do SUS [Sistema Único de Saúde] e das empresas que detêm concessão ou permissão de serviço de assistência à saúde, por profissionais capacitados para o uso da Libras ou para tradução e interpretação; e

X - apoio à capacitação e formação de profissionais da rede de serviços do SUS para uso de Libras e sua tradução e interpretação. (BRASIL, 2005).

Essa garantia normativa não condiz, necessariamente, a alguns dos enunciados de mães de crianças surdas, abordados anteriormente, quando elas afirmaram que alguns profissionais da área da saúde não recomendavam o uso da Libras principalmente quando essas crianças são implantadas.

Para complementar esse posicionamento discursivo, por parte de alguns profissionais da área da saúde, cito um trecho do relato do médico que consta na notícia vinculada no site da Associação Brasileira de Otorrinolaringologia e Cirurgia Cérvico-Facial ${ }^{12}$, na ocasião em que alguns membros da mesma entraram em contato com os diretores de marketing, da rede Globo de televisão, para conversarem sobre o personagem surdo da novela "Cama de Gato", exibida entre outubro de 2009 e abril de 2010.

"Entregamos uma carta ao E., assinada por dez professores doutores de várias
universidades federais e estaduais - [...] além de mim -, pedindo que se preste
atenção no implante coclear como tendência mundial em tratamento de surdez
severa e profunda e que consideramos um retrocesso o uso de Libras na novela".
$\mathrm{Na}$ reunião, houve um pedido dos quatro médicos presentes para os diretores
encaminharem às autoras da novela "Cama de Gato" [...], o cuidado que devem ter
em relação à linguagem de sinais. "Os telespectadores da novela que vivenciam o
problema poderão prejudicar a decisão de famílias que virão a tratarem seus filhos
surdos. Temos que respeitar a vontade daqueles adultos que não tiveram a

${ }^{12}$ Notícia disponível em: <http://www.sborl.org.br/conteudo/secao.asp?id=2092\&s=51 > Acesso em 10 jun. 2013. 
oportunidade de serem implantados e hoje desejam continuar surdos. Mas não se pode negar às crianças pequenas, que ainda não podem decidir por si próprias, o direito de serem ouvintes", diz.

Trata-se de um enunciado proferido após a aprovação do Decreto e que se vincula ao discurso da normalidade pautado no ouvinte, fato que evidência que a normatividade legal, ao fazer parte das relações de poder e saber que envolve a área da surdez, também sofre com processos de resistência discursiva.

Para finalizar, o reconhecimento e a disseminação da Libras no contexto legislativo por meio da Lei $n^{\circ} 10.436 / 02$ e do Decreto $n^{\circ} 5.626 / 05$, apontam medidas que pactuam com alguns estudos acadêmicos sobre a língua de sinais e com os enunciados proferidos pela comunidade surda e por alguns ouvintes, ampliando a circulação do discurso pautado na diferença linguística e cultura do "ser" surdo. Fato que pode contribuir para permeabilidade da Libras na sociedade brasileira e o envolvimento de surdos e uma quantidade cada vez maior de ouvintes com essa língua.

Nesse sentido, a seguir explanarei o campo de atuação profissional que contempla o uso da língua de sinais no Brasil e que se encontra, atualmente, em franca expansão.

4.3 A ampliação de práticas que contemplam o uso da língua de sinais com surdos e com ouvintes no cenário brasileiro

Conforme o que foi descrito nas seções anteriores, a ascensão da proposta educacional bilíngue e multicultural, os estudos linguísticos sobre as línguas de sinais, o reconhecimento legislativo da Libras e a resistência do movimento surdo, contando com a parceria de alguns ouvintes adeptos ao movimento, podem favorecer a instauração de práticas que priorizam o contato e o conhecimento da língua de sinais e de seus usuários.

No Brasil, do início dos anos 1990 até os dias atuais, instituíram-se processos que fortaleceram o paradigma discursivo focado na construção de saberes, cuja norma, pauta-se no surdo. Essa mudança no teor discursivo influenciou a consolidação de ações que envolvem o uso e desenvolvimento da Libras no interior das comunidades surdas e em outras áreas da sociedade, especialmente, a educacional. Tais ações serão explanadas, brevemente, nos itens a seguir, primeiro com foco nos surdos e, posteriormente, no que diz respeito aos ouvintes. 


\subsubsection{Os surdos e a língua de sinais: aquisição e ensino}

Quando se considera a aquisição da língua de sinais por surdos, tradicionalmente, duas situações podem facilitar ou dificultar o acesso, o desenvolvimento e o uso da língua de sinais como L1. Tais situações estão vinculadas ao tipo de família que a criança surda tem, se é uma família composta por membros surdos ou se é composta por membros ouvintes.

Poucos são os casos em que o surdo tem pais e/ou outros membros da família surdos, mas quando isso ocorre, a aquisição da língua de sinais se torna mais espontânea e constituise como a língua materna dessa criança, desde a mais tenra idade. Essa situação costuma ser encarada de forma positiva pelas comunidades surdas e o sucesso escolar de crianças nessa condição é atribuído, por pesquisadores, como superior aos das crianças que nasceram em famílias ouvintes.

Mas como a maioria das crianças surdas nasce em famílias com membros ouvintes, o período de aquisição da L1 se torna variável e ocorre a partir do momento em que as mesmas começam a ter contato com outros surdos e/ou ouvintes usuários das línguas de sinais. E, isso pode acontecer durante a infância ou até mesmo na adolescência ou fase adulta.

O relato sobre a vida de um surdo evidência um dos tipos de relações que a família ouvinte e o filho surdo podem ter com a língua de sinais:

\footnotetext{
Quando ele era pequeno, a família tinha apenas conhecimento do Oralismo e conversava usando leitura labial e gestos [...]. [a partir da adolescência ao ingressar numa associação de surdos] conheceu muitos surdos, recebeu mais informações sobre a vida dos surdos, principalmente em relação à cultura, trabalho, educação, esportes... Segundo ele, sua vida mudou. Até a compreensão do português melhorou na medida em que ele aprendeu Libras. [...] A irmã de B. L. aprendeu Libras com ele e no contato com seus amigos surdos. Ela e a mãe fizeram cursos de Libras para melhorar a comunicação com os surdos. [...] Somente seu pai não usa Libras. Apesar de ter interesse, ele tem dificuldade em movimentar as mãos. Além do mais, o português falado por ele é difícil para B. L. entender. Essa é a sua maior dificuldade de relacionamento com seu pai: a comunicação. (VERGAMINI, 2003, p. 63).
}

Numa situação marcada pela presença de familiares ouvintes, atribui-se a escola um papel fundamental, pois se nela existem outros surdos ou profissionais fluentes na língua de sinais, a aquisição da L1 se torna mais rápida, com reflexos positivos nas relações sociocomunicativas favorecedoras das construções identitárias, do contato, consumo e produção cultural, do acesso ao conhecimento de mundo, enfim, de todas as possibilidades de desenvolvimento humano que qualquer pessoa tem direito, independentemente, de ser surda ou ouvinte.

Nesse mesmo sentido, Lopes e Veiga-Neto consideram que:

[...] o lugar atribuído à escola e a força que esta adquire nos tempos modernos, não

há como não ser constituído por ela, principalmente se a comunidade à qual 
pertencemos tem o espaço escolar como uma possibilidade de existência. A comunidade surda tem, ao longo dos anos, transformado o espaço escolar em lugar de sua própria construção. Como um lugar de encontro, os surdos transformam a escola em um campo frutífero de articulação e invenção de marcas culturais. (2006, p.92)

Em nosso país a educação bilíngue tem se configurado no contexto da proposta inclusiva em escolas regulares de ensino. Nessa perspectiva os alunos surdos frequentam escolas e classes com alunos ouvintes e neste modelo deveriam contar, conforme resguardado na legislação, com a presença de Tils e de professores capacitados e conhecedores da singularidade linguística e cultural do aluno surdo, além de ter acesso ao Atendimento Educacional Especializado (AEE) no período contrário ao da escolarização regular.

Além dessa proposta, também existe outro tipo de educação bilíngue que, apesar de não ser um modelo predominante, está presente em algumas grandes cidades brasileiras, dentre elas a cidade de São Paulo. A proposta de educação bilíngue, nessa e em outras cidades, se caracteriza pela oferta de classes ou escolas específicas para surdos nas quais os alunos contam com professores bilíngues ouvintes e/ou surdos nas diferentes disciplinas curriculares, desde a Educação Infantil até o Ensino Fundamental I ou II, dependendo da escola. E a partir do Ensino Fundamental II ou do Ensino Médio os alunos são incluídos em escolas regulares e contam com os profissionais e serviços mencionados sobre a educação bilíngue na perspectiva inclusiva.

Tomando como premissa esses dois modelos principais de oferta educacional bilíngue para surdos, várias produções emergem defendendo e/ou problematizando as vantagens e desvantagens linguísticas, identitárias, culturais e educacionais que alunos surdos têm quando estudam em um ou outro modelo de escola. Para exemplificar as tendências discursivas desses estudos conto com pesquisa de Dallan (2013) “Análise discursiva dos estudos surdos em educação: a questão da escrita em sinais”.

A autora, ao se debruçar sobre alguns documentos produzidos pela Política Nacional de Educação Especial (PNEE) do Ministério da Educação (MEC) e de alguns artigos acadêmicos presentes na série "Estudos Surdos", optou por uma descrição arqueológica baseada em Foucault. E, de acordo com a análise realizada:

O MEC preconiza a Educação Bilíngue como forma de ensino à pessoa com surdez; os Movimentos em prol da Educação e da Cultura Surda [os Estudos Surdos] exigem, também uma educação bilíngue. No entanto, socialmente, as duas instâncias divergem com relação ao local de ensino: os Movimentos Surdos exigem uma escola própria para surdos quando se trata de crianças, para que estas adquiram fluência linguística e desenvolvam-se culturalmente em ambiente de Escola Bilíngue para Surdos (Escola especial, se levarmos em conta o parâmetro do MEC). Já o 
ministério da Educação determina que a escola deva adequar-se às necessidades de todos os alunos, inclusive às dos surdos falantes de Libras. (DALLAN, 2013, p. 82).

Dallan (2013, p. 109) ainda considera que:

\begin{abstract}
Todo o conjunto de enunciados, conceitos e escolhas teóricas apresentados nos excertos coletados funcionam - através dos Estudos Surdos - como um conjunto de conhecimentos sistematizados que produzem um espaço de possibilidades. No conjunto dessa formação discursiva é possível se ocupar uma posição para falar contra os sujeitos-objetos de que se ocupa o discurso oficial, através do AEE e da PNEE na Perspectiva Inclusiva. Nessa outra instância de formação discursiva, esse sujeito tem uma deficiência auditiva que pode ser superada por práticas pedagógicas adequadas. Por ser sujeito pleno de possibilidades, não deve estar restrito ao "mundo dos surdos", pois está limitado pelas barreiras geográficas da nação brasileira, cuja língua e cultura são traduzidos na língua oral escrita.
\end{abstract}

Nesse sentido, a proposta bilíngue das escolas regulares na perspectiva inclusiva, e que consta em documentos, cursos e materiais de formação de professores vinculados ao MEC, tem sido alvo de críticas por boa parte dos enunciados produzido pelas comunidades surdas, por alguns pesquisadores do meio acadêmico e por vários profissionais que atuam diretamente nas escolas. Tais enunciados apontam como maior problema na educação inclusiva a forma com que a mesma foi implementada no Brasil, principalmente, no que se refere à precariedade em termos estruturais, materiais e de profissionais capacitados para atender as peculiaridades do alunado.

Muitos alunos surdos incluídos, em várias escolas espalhadas pelas diferentes cidades brasileiras, não têm desfrutado da oportunidade de acesso, uso e desenvolvimento da língua de sinais, e nem sempre o encontro surdo-surdo é possível e/ou incentivado, quando se pensa na construção identitária e no contato com a cultura surda, estas são prerrogativas primordiais no contexto discursivo da diferença linguística e cultural, do qual se vincula a proposta educacional bilíngue para surdos.

Diante dessa situação, o movimento surdo tem lutado contra o fechamento das escolas voltadas para surdos e a cidade de São Paulo é um exemplo dessa luta. Durante a campanha eleitoral municipal, no ano de 2012, a Federação Nacional de Educação e Integração de Surdos (Feneis) elaborou um documento ${ }^{13}$ no qual solicitava o compromisso do prefeito Fernando Haddad, ainda candidato na época, em manter as escolas para surdos da cidade,

\footnotetext{
${ }^{13}$ Documento disponível na íntegra em:< http://bilinguesparasurdosja.com/2012/10/25/haddad-assinacompromisso-manter-apoiar-escolas-bilingues/>. Acesso em: 24 mai. 2013.
} 
atendendo ao que já havia sido estabelecido para as referidas escolas por meio do Decreto Municipal no 52.785/11 (SÃO PAULO, 2011).

Os movimentos surdos além se de se articularem politicamente elaboram documentos e se apoiam naqueles já existentes no processo de ampliação da normatização de seus ideais linguísticos e culturais. E, contam com o que tem sido produzido academicamente e divulgados em publicações como a série "Estudos Surdos".

De acordo com Quadros na apresentação da série dos "Estudos Surdos", as investigações:

[...] rompem com a mesmidade. Os Surdos começam a ser autores, embora, ainda neste primeiro volume, as pesquisas tenham sido produzidas na sua grande maioria por ouvintes. Mesmo assim, esses ouvintes estão sensíveis aos olhares surdos e chamam a atenção para as perspectivas do outro surdo. [...] O contexto em que se apresentam tais ensaios, pesquisas e relatos é de tensão e, ao mesmo tempo, de conquistas. (QUADROS, 2006, p. 9).

Em contrapartida, de acordo com a análise de Dallan:

\begin{abstract}
A proposta do AEE-MEC é uma versão contemporânea da visão clínica-terapêutica da surdez, pois percebe o sujeito surdo como Deficiente Auditivo, passível de reabilitação através de práticas pedagógicas adequadas; esse sujeito, que tem uma deficiência auditiva, não precisa ser pensado culturalmente dentro da escola, pois a atividade proposta nesta instância, dois turnos escolares, o auxiliarão na superação de necessidade educacional especial. (2013, p. 147).
\end{abstract}

Além das propostas bilíngues para surdos vigentes no país, se torna válido mencionar que a aquisição da língua pelos surdos ocorre, geralmente, por meio do contato e uso de línguas que se caracterizam pela produção e expressão em três modalidades distintas. Como já mencionei, as línguas de sinais são línguas de modalidade visual-motora e são consideradas como L1 no bilinguismo, e as línguas orais de modalidade oral-auditiva a L2. Estas são amplamente adquiridas e utilizadas na modalidade escrita, principalmente em comunidades consideradas como majoritárias. Mas existem várias línguas dessa modalidade que não fazem uso de nenhum código de escrita.

No que concerne às línguas de sinais, alguns estudos tem se concentrado na ideia de registrar as mesmas de acordo com um sistema de notação desenvolvido, a partir dos anos de 1970, por Valerie Sutton que registrava as orientações e movimentos do corpo no espaço em coreografias de dança.

Por meio desse estudo inicial, houve a criação do denominado SignWriting ou Escrita em Língua de Sinais (ELS) que: 
[...] é um sistema secundário de representação de informação, baseado no sistema primário que é a Língua de Sinais. Do mesmo modo como sistemas de escritas alfabéticos representam os fonemas de que se compõem as palavras das diversas línguas faladas, enquanto sistema de escrita visual direta, Sign Writing representa os quiremas de que se compõem os sinais nas diversas Línguas de Sinais. (CAPOVILLA et al., 2001, p. 1495).

Houve o crescimento dos estudos com foco na ELS, como os realizados no Brasil pelas pesquisadoras Stumpf (2004) e Dallan (2013), mas a utilização desse sistema se restringe a poucas iniciativas em escolas para surdos.

Como exemplo, cito a experiência relatada por Dallan (2013, p. 172):

\begin{abstract}
$O$ processo de ensino da sinalização escrita iniciou-se com o aprendizado das unidades mínimas que compõe o sinal (palavras em Libras). O primeiro passo foi a escrita do sinal pessoal. Foram momentos prazerosos, de muitas descobertas, bastante diferentes das aulas de português como segunda língua, nas quais eles se sentiam inseguros, embora este ensino fosse necessário a sua vida como um todo. Quando já faziam leitura de vários sinais, apresentei um texto: "A piada da árvore surda", um texto cômico em escrita de sinais. Percebi, na apresentação deste texto, que o projeto era totalmente possível: dois alunos que liam com maior fluência, sorriram da piada, comentando o conteúdo comigo.
\end{abstract}

Porém, ao mesmo tempo em que se publicam relatos práticos sobre o uso do SignWritting com alunos surdos, tal sistema tem sido considerado como uma escrita "artificial", que não corresponde, necessariamente, ao registro escrito dos sinais (LODI; HARRISON; CAMPOS, 2012; ALBRES, 2012; LEITE; McCLEARY, 2009) mas que pode contribuir "para estudos mais aprofundados das línguas de sinais por possibilitar uma análise descritiva dos elementos formacionais manuais e não manuais constitutivos da língua" (LODI; HARRISON; CAMPOS, 2012, p. 14).

O que se observa é que poucos são os surdos que aprenderam e que utilizam o SignWritting como forma de registro escrito em seu cotidiano, a maioria recorre à modalidade escrita da língua oral, no caso do Brasil, à Língua Portuguesa.

No que se refere ao conhecimento da Libras pelos profissionais que fazem parte da educação, esta é uma demanda que tornou-se imprescindível para o desenvolvimento das crianças surdas, no contexto do discurso da diferença linguística e cultural.

No entanto, nos anos que apontavam o início da implementação da educação bilíngue e que antecederam o reconhecimento oficial da Libras, os cursos existentes sobre esta língua eram promovidos de forma aberta ao público, principalmente, por associações de surdos, instituições de iniciativa religiosa ou educacional. Algumas faculdades que tinham cursos habilitavam para o ensino de surdos no ensino básico e, esporadicamente, algumas secretarias 
de educação de Estados e Municípios ofertavam cursos voltados ao quadro de professores das mesmas.

Esses cursos eram ministrados por surdos com ou sem a presença de Tils; por ouvintes fluentes em Libras que eram filhos de pais surdos (CODA - Children of Deaf Adults) ou que tinham algum vínculo familiar com surdos; por Tils, geralmente de igrejas; ou por professores ou profissionais que trabalhavam diretamente com surdos. Raramente, se encontrava outros perfis de pessoas ministrando cursos de Libras.

A profissão de instrutor ou professor de Libras, por ser mais recente, ainda não faz parte do quadro oficial de muitas instituições educacionais do país. Mas, paulatinamente, algumas instituições ou secretarias de educação das esferas Federais, Estaduais e Municipais tem aberto concurso público para o provimento de profissionais para atuarem diretamente com a língua de sinais. Outras instituições, públicas e privadas, recorrem ao contrato temporário ou registro em carteira profissional para atender as normas estabelecidas nas legislações.

Com a demanda propiciada pelo Decreto $\mathrm{n}^{\circ}$ 5.626/05, os cursos de Libras se expandiram em grandes proporções e além desses profissionais que já ministravam cursos terem sido absorvidos pelo mercado, mais pessoas eram - e são - requisitadas para atuarem com essa língua. Muitos surdos adultos além de fazerem parte e militarem nas causas do movimento surdo, também estão se vinculando ao processo de disseminação, aquisição e ensino da Libras.

Alguns surdos têm participado de cursos de capacitação e multiplicação das estratégias de ensino da língua de sinais, em diferentes Estados brasileiros, promovidos pela Feneis. Outros surdos são formados em diferentes áreas que não são, necessariamente, a área da educação ou da linguística, trabalham em outras profissões e, paralelamente, exercem a função de instrutor ou professor de Libras em instituições, associações, escolas e faculdades que visam o ensino dessa língua no processo de capacitação ou formação de profissionais ouvintes para atuarem com surdos, seja na educação, na tradução/interpretação ou no atendimento realizado em Libras em diferentes setores de prestação de serviço à população.

Afim de, atender a demanda criada por instrutores ou professores de Libras, o Decreto $\mathrm{n}^{\circ}$ 5.626/05 prevê a abertura e oferta de cursos de Letras-Libras, bem como a aplicação anual de exames de proficiência em Libras, o denominado Prolibras, pelo MEC, no período compreendido entre o ano de 2006 e 2015.

Os cursos de Letras-Libras foram, pioneiramente, organizados pela Universidade Federal de Santa Catarina (UFSC) e ofertado na modalidade de Educação à Distância (EAD) 
em polos espalhados por diversas universidades presentes nos Estados brasileiros e, atualmente, a UFSC também conta com o curso na modalidade presencial. Dessa forma, novas possibilidades foram abertas para formação e atuação dos surdos com relação à sua língua, bem como para ouvintes também usuários e fluentes na Libras como L2.

Além dessas duas possibilidades que atestam a formação de instrutores ou professores de Libras, também tem crescido a oferta de cursos presenciais e na modalidade EAD de pósgraduação Lato Sensu, principalmente, em instituições privadas de Ensino Superior, em todo o Brasil. No entanto, como nesses cursos, geralmente, não há exigências prévias sobre nível de proficiência em Libras, neles pode haver a presença de alunos surdos usuários e fluentes na língua de sinais como L1, ouvintes fluentes na mesma como L2 ou ouvintes que nunca tiveram contato com a língua de sinais ou a comunidade surda.

Esse tipo de formação, ao mesmo tempo em que favorece o crescimento de profissionais habilitados para atuarem com a Libras, também põe em debate o surgimento de uma situação problemática nesse campo, a questão que circula entre alguns profissionais mais experientes na área é: pessoas que nunca tiveram contato com a língua de sinais, em um período de 12 ou 18 meses, podem receber um certificado que lhes habilitam para o ensino da Libras desde o ensino básico até a Educação Superior?

Essa foi uma preocupação da pesquisadora surda Rebouças (2009) em sua dissertação de mestrado intitulada: "A prioridade dos docentes surdos para ensinar a disciplina Língua Brasileira de Sinais (Libras) nas instituições de ensino superior após o Decreto 5.626/2005". De acordo com os resultados da pesquisa com professores surdos e ouvintes da disciplina, a autora aponta que:

A diferença entre o total de 85 IES encontradas e de professores surdos participantes da pesquisa, dezenove, me leva a suspeitar que existe um número expressivo de professores ouvintes que passaram a ensinar Libras após a publicação do decreto 5.626/05, burlando a prioridade legal com a apresentação de currículos titulados e aproveitando a falta de critério dos dirigentes das IES. (REBOUÇAS, 2009, p. 114).

Alguns membros das comunidades surdas e pesquisadores têm demonstrado em seus enunciados a preocupação com o fato de pessoas com pouco envolvimento com as comunidades surdas atuarem profissionalmente com a língua de sinais ou incorporarem e propagarem normas pautadas nos ouvintes, conforme citam Rangel e Stumpf (2012, p.119):

As lideranças surdas, embora apontem para o avanço que constituiu reconhecer a língua de sinais e o esforço feito pelos responsáveis pelo ensino especial para provocar uma mudança nas escolas [...] consideraram que as medidas são ainda superficiais, que o poder nas escolas e nas classes de surdos continua nas mãos dos ouvintes e que se pensa nos surdos apenas como instrutores de língua de sinais, ainda assim, substituíveis por ouvintes que, muitas vezes, dominam muito mal essa 
língua. A inclusão, conceito bonito e desejável, na prática funciona como exclusão. Exclusão de comunicação, exclusão de real participação.

Tais enunciados reverberam as tensões existentes em torno das relações de poder e saber que envolve a língua de sinais e os responsáveis em ministrá-la institucionalmente.

Para finalizar a discussão proposta neste capítulo, me ocuparei adiante de uma breve explanação sobre as possibilidades do uso da língua de sinais pelos ouvintes. Pois, ao se tomar as prerrogativas do discurso pautado na diferença linguística e cultural, a proposta de educação bilíngue e as normas estabelecidas legalmente sobre a Libras favorecendo o "ser" surdo, foram abertas possibilidades para que a população ouvinte se torne usuária da língua de sinais como L2, se envolva e participe das comunidades surdas e estabeleçam o contato com as produções culturais oriundas dessas comunidades.

\subsubsection{Os ouvintes e as demandas de aprendizado da Libras}

Quando se analisa o perfil das pessoas descritas em diferentes produções na área da surdez, se evidencia que há algumas décadas o interesse dos ouvintes pela língua de sinais se relacionava ao contato pessoal que eles tinham com as comunidades surdas como os estabelecidos pelos CODA, que muitas vezes adquiriram a língua de sinais como L1, parentes, vizinhos e amigos de surdos. Por profissionais que atuavam com este público como, por exemplo, os ouvintes que se formavam na área de fonoaudiologia ou da educação, principalmente, os que procuravam a denominada "educação especial". Ou ainda com ouvintes envolvidos com instituições religiosas, alguns mediando a comunicação da Libras para Língua Portuguesa e vice-versa, durante cultos e missas, outros na área educacional.

Atualmente, além das pessoas que tem contato com a Libras pelos motivos supracitados, a visibilidade da língua de sinais no cenário discursivo brasileiro ampliou o interesse pessoal ou profissional pelo aprendizado dessa língua em cursos livres, assim como normatizou, institucionalmente, o aprendizado da mesma, por meio da obrigatoriedade da disciplina de Libras para o público que está matriculado em cursos superiores de licenciatura e de fonoaudiologia no Ensino Superior.

Gesser (2012) aponta que nos cursos de Libras que ela pesquisou há uma grande heterogeneidade nos perfis dos ouvintes que procuraram tais cursos e isso decorre, segundo 
sua hipótese, do fato de não haver uma tradição na oferta dos mesmos, bem como de não haver muitos cursos que contemplem a continuidade e o nivelamento.

Dentre as razões que motivam ouvintes a procurarem cursos de Libras a autora destaca as de cunho familiar, profissional e de aprendizes de outras línguas, ressaltando o fato que tais públicos demandam diferentes abordagens por parte dos instrutores ou professores de Libras, pois os objetivos desses aprendizes são diferentes e requerem adequação tanto nos conteúdos que serão abordados, quanto nas estratégias que serão empregadas.

$\mathrm{Na}$ última década os cursos de Libras começaram a ser ofertados, de forma mais organizada, por diversas instituições que além de contarem com profissionais surdos ou ouvintes proficientes, realizam cursos com maior carga horária atendendo do nível básico ao avançado, além de cursos voltados, especificamente, para as demandas de tradução e interpretação da Libras-Língua Portuguesa, preparatório para o exame Prolibras e para formação de instrutores.

No que se refere aos cursos de Libras no Ensino Superior, observa-se o crescimento pela oferta de cursos de extensão universitária, com características mais introdutórias e básicas à língua de sinais, bem como a disciplina Libras de caráter obrigatório ou opcional, dependendo do curso e do curso de licenciatura em Letras-Libras.

Diante da normatividade e do meu interesse, enquanto pesquisadora e docente da disciplina Libras, pode-se considerar que as disciplinas na área da educação:

[...] intervêm igualmente na história cultural da sociedade. Seu aspecto funcional é o de preparar para aculturação dos alunos em conformidade com certas finalidades: é isso que explica sua gênese e constitui sua razão social. Mas se as consideram em si mesmas, tornam-se entidades culturais, como outras, que transpõem os muros da escola, penetram na sociedade, e se inscrevem na dinâmica de uma outra natureza. (CHERVEL, 1988, p. 117).

A disciplina Libras ao assumir esse caráter de permeabilidade no plano discursivo que envolve as relações de poder e saber culturais, especificamente, no Ensino Superior, favorece reflexões e construções de conhecimento sobre os surdos e aquilo que eles defendem.

Nesse sentido, ao realizar um levantamento bibliográfico relacionado às construções discursivas que permeiam a língua de sinais, enquanto disciplina no Ensino Superior, encontrei algumas publicações relacionadas ao tema, das quais descreverei a seguir.

A primeira consiste em um estudo sobre os desafios da implementação da Libras no Ensino Superior (PEREIRA, 2008) que relata que dos dez cursos das oito instituições pesquisadas em cidades do estado de São Paulo e Minas Gerais, apenas quatro haviam 
inserido a disciplina Libras nas IES e a maior dificuldade apontada pelos coordenadores entrevistados encontrava-se na adequação da carga horária ao conteúdo a ser ministrado.

A pesquisa de Rebouças (2009) também se concentrou no Ensino Superior e foi dirigida tanto aos professores surdos e ouvintes, quanto aos alunos da disciplina Libras, nos cursos de Fonoaudiologia, Pedagogia e Letras. Dos dados expostos sobre os alunos o que chamou a atenção foi a preferência pelas aulas de Libras por professores surdos, o percentual de preferência em ter aulas com professores surdos ou com professores ouvintes foi, respectivamente, de $15,6 \%$ e 4,4\%. Os professores surdos também opinaram de forma favorável a atuação de docentes surdos no ensino de Libras. E, assim como a pesquisa de Pereira (2008), um dos enunciados recorrentes sobre as dificuldades percebidas pelos alunos e docentes era a insatisfação com a carga horária destinada à disciplina.

Caetano (2011) escreveu um artigo sobre a disciplina Libras no curso de Pedagogia, mas teve como foco a importância dessa disciplina do ponto de vista dos alunos. A autora, através da sua pesquisa fez várias considerações sobre a aprendizagem da Libras, mas destacarei dois fatores relatados e que dificultavam o processo de aprendizagem da mesma. $\mathrm{O}$ primeiro diz respeito, mais uma vez, à pouca carga horária e o outro ao conteúdo teórico proposto, segundo a autora, por falta de conhecimentos prévios por parte dos alunos, se tornava difícil o aprofundamento dos assuntos/tópicos apresentados.

Por último, a publicação da linguísta Pereira et. al. (2011), em parceria com alguns professores e pesquisadores surdos da disciplina Libras, abordou aspectos básicos e fundamentais relacionados ao ensino e a aprendizagem da língua de sinais nos cursos de licenciatura e fonoaudiologia no Ensino Superior. A proposta do livro foi a de oferecer subsídios aos professores de língua de sinais na elaboração de suas propostas com relação à disciplina. Nesse sentido, contempla desde a história da educação de surdos e a importância da língua de sinais nessa trajetória, até a análise de aspectos linguísticos, finalizando com uma proposta de metodologia de ensino focada na concepção discursiva de língua.

Apesar da existência das pesquisas relatadas, estas ainda representam uma temática pouca explorada. $\mathrm{O}$ ensino da Libras, em cursos livres para o público ouvinte ou a disciplina Libras, obrigatória, em cursos de licenciatura e fonoaudiologia no Ensino Superior ou, optativamente, nos outros cursos, demandam a ampliação de investigações que possam apontar, corroborar, discutir e/ou problematizar as construções discursivas presentes nas práticas empreendidas nas aulas, aproximando ou distanciando-se dos conjuntos de 
enunciados, que permeiam a área da surdez e, amplamente abordados, ao longo da fundamentação teórica desta pesquisa.

Para concluir, considero que as relações de poder e saber em torno das línguas que os surdos devem ou não adquirir estão longe de se extinguirem ou estabilizarem e, além de se localizarem ora no discurso da deficiência, ora no discurso da diferença linguística e cultural, tendem a se propagarem sem uma delimitação fronteiriça totalmente evidente. Tais discursos, ao longo dos anos, têm servido como regimes de verdade por diferentes sujeitos e instituições disciplinares cujas normas, pautadas no ouvinte, no surdo ou em ambos, são delineadas para atenderem os contextos social, educacional e político de cada época.

Nesse sentido, tendo como princípio a ampliação das reflexões na área da surdez, especialmente quando a mesma emerge vinculada ao discurso da diferença linguística e cultural, nos próximos capítulos desdobrarei esforços na descrição metodológica da pesquisa que realizei sobre a disciplina Libras no Ensino Superior e na apresentação e discussão dos dados da investigação empreendida. 


\section{PERCURSOS INVESTIGATIVOS}

Conforme mencionei na introdução do presente trabalho, o objetivo geral desta pesquisa consiste em: Verificar a contribuição da disciplina Libras nos cursos superiores de licenciatura para circulação do discurso da diferença linguística e cultural das comunidades surdas.

As línguas de sinais constituem-se como uma das principais marcas culturais dessas comunidades e ao considerar o reconhecimento da Língua Brasileira de Sinais e os processos de normatização que perpassam a mesma, enquanto disciplina curricular no Ensino Superior, torna-se imprescindível que outros objetivos mais específicos sejam estabelecidos nesta pesquisa, tais como:

- Levantar os perfis dos docentes da disciplina, enquanto sujeitos do discurso;

- Levantar e analisar os dados referentes ao processo de institucionalização da disciplina Libras nas IES;

- Identificar os principais enunciados que têm circulado em torno da disciplina Libras, por meio dos sujeitos do discurso envolvidos e dos planos de ensino das IES, no que se refere aos objetivos, aos conteúdos e as possíveis estratégias adotadas;

- Relacionar os perfis dos sujeitos do discurso, a institucionalização da Libras e os enunciados que permeiam a disciplina, delineando as relações que podem contribuir para circulação do discurso da diferença linguística e cultural das comunidades surdas nos cursos superiores de licenciatura.

Com os objetivos expostos, neste capítulo me concentrarei nas escolhas metodológicas, nos instrumentos e nos procedimentos adotados para a coleta de dados da pesquisa, e na caracterização inicial dos participantes, pois o perfil detalhado dos mesmos compõe, especificamente, uma parte da análise dos dados que constarão no capítulo intitulado "A cultura surda nos cursos de licenciatura: práticas e perspectivas no ensino da Língua Brasileira de Sinais". 


\subsection{Fundamentação metodológica}

Este trabalho consiste em uma pesquisa qualitativa, cuja ênfase se deu na aplicação de questionário estruturado com perguntas abertas e na análise documental dos planos de ensino da disciplina Libras. Mas antes de adentrar nas etapas que compuseram o presente estudo, contextualizarei, brevemente, os aspectos que caracterizam os estudos qualitativos.

Conforme apontam Bogdan e Biklen a investigação qualitativa em educação pode ser realizada de diferentes formas e contextos, mas:

Os dados recolhidos são designados por qualitativos, o que significa ricos em pormenores descritivos relativamente a pessoas, locais e conversas, e de complexo tratamento estatístico. As questões a investigar não se estabelecem mediante a operacionalização de variáveis, sendo, outrossim, formuladas com o objectivo de investigar os fenômenos em toda a sua complexidade e em contexto natural. (1994, p. 16).

Bogdan e Biklen (1994) citam que a pesquisa qualitativa apresenta cinco características, sendo elas:

- A fonte de dados é o ambiente natural;

- A investigação é descritiva;

- O investigador se preocupa mais com o processo e não simplesmente com os resultados;

- Existe uma tendência, pelo investigador, de análise indutiva dos dados;

- O significado é de vital importância na abordagem.

Tais características aparecem em maior ou menor grau, de acordo com a especificidade do que se está pesquisando e os investigadores qualitativos:

[...] estabelecem estratégias e procedimentos que lhes permitam tomar em consideração as experiências do ponto de vista do informador. O processo de condução da investigação qualitativa reflecte uma espécie de diálogo entre os investigadores e os respectivos sujeitos, dado estes não serem abordados por aqueles de uma forma neutra. (BOGDAN; BIKLEN, 1994, p. 51).

Para esta pesquisa, estabeleci a utilização de um questionário estruturado que possibilitasse "recolher dados descritivos na linguagem do próprio sujeito, permitindo ao investigador desenvolver intuitivamente uma ideia sobre a maneira como sujeitos interpretam aspectos do mundo" (BOGDAN; BIKLEN, 1994, p. 134) e, de forma complementar, a análise do plano de ensino que descreve uma perspectiva documentada que apresenta e norteia a organização e a prática na disciplina Libras. 
A seguir, descreverei como se deu a composição do questionário estruturado aplicado.

\subsection{Instrumentos utilizados na coleta de dados}

No processo de elaboração do questionário tive o cuidado de selecionar questões, quatorze no total, que não gerassem desconforto ou desmotivação no processo de reflexão e resposta dos docentes e que os assuntos intrínsecos a cada uma delas permitissem certa liberdade e/ou flexibilidade nos relatos sobre as experiências, pontos de vistas e formas de agir dos profissionais participantes. Ressalto que o mesmo instrumento foi empregado como roteiro com uma das participantes que tive a oportunidade de realizar a coleta de informações pessoalmente e registrá-las em áudio.

A primeira parte do questionário, com oito perguntas, teve como intuito levantar os informes concernentes ao perfil docente dos participantes e também alguns aspectos que complementam a elucidação do processo de institucionalização da disciplina, com foco nos seguintes temas:

- Identificação pessoal com a informação de ser surdo ou ouvinte;

- Formação acadêmica;

- Certificação de proficiência em Libras e respectiva categoria;

- Tipo de IES que ministra aula;

- Cursos que ministra a disciplina;

- Tempo que ministra a disciplina na IES pesquisada;

- Aquisição e desenvolvimento da Libras;

- Experiências relacionadas à área da surdez e Libras.

Já a segunda parte, composta por seis perguntas abertas, foi a responsável pela coleta de mais algumas informações que também contribuiriam para a compreensão do processo de institucionalização da disciplina, mas com foco na comunidade acadêmica, e questões que versavam sobre a prática docente e que condiziam com os seguintes temas:

- Reação da comunidade acadêmica frente à disciplina;

- Objetivos do docente com relação à disciplina; 
- Principais assuntos abordados nos conteúdos;

- Modalidades comunicativas utilizadas nas aulas;

- Como a cultura surda tem sido abordada nas aulas;

- Percepção dos discentes sobre a disciplina.

De forma complementar aos dados prestados pelos docentes, os planos de ensino foram solicitados pensando nos objetivos gerais, na metodologia, nos conteúdos elencados e na avaliação.

Assim, espera-se que a análise de todas as informações coletadas por meio dos instrumentos selecionados e descritos possam oferecer pistas, questionamentos, reflexões e asserções sobre as regularidades nos conjuntos de enunciados que perfazem as aulas da disciplina Libras nos cursos superiores de licenciatura.

5.3 Procedimentos para coleta de dados

O Decreto Federal $n^{\circ}$ 5.626/05 estabelece o prazo de dez anos para inclusão da disciplina Libras em 100\% dos cursos de licenciatura, ou seja, este prazo se esgotará em 2015. Nesse sentido, ao iniciar o processo de seleção das IES já contava com a possibilidade de algumas instituições ainda não terem a disciplina na grade curricular. Por isso, realizei um mapeamento prévio, pela rede mundial de computadores, de IES presentes na cidade de São Paulo e região metropolitana, e a partir das descrições observadas nos sites de cada instituição entrei em contato com os coordenadores dos cursos de licenciatura solicitando algumas informações iniciais para verificar se a instituição atendia aos seguintes critérios:

- Inclusão da disciplina Libras na grade curricular em, no mínimo, um curso de licenciatura;

- Oferta presencial da disciplina Libras;

- Experiência do docente da disciplina Libras há no mínimo um bimestre letivo na IES.

Entrei em contato com cerca de trinta e cinco coordenadores de cursos de licenciatura de um universo de dezesseis IES públicas e privadas. Nessa etapa os coordenadores que retornaram assinalavam os cursos de licenciatura pelo quais eram responsáveis e que já atendiam os critérios estabelecidos para a pesquisa, ou seja, além de terem a disciplina na 
grade curricular, a mesma era ofertada de forma presencial por um docente que estava vinculado à IES há mais de um bimestre letivo.

Considero válido destacar que dois coordenadores pediram aos funcionários da secretaria do curso/IES para disponibilizarem as informações solicitadas. Um deles, apesar de fornecer as informações, também pediu para que confirmasse alguns dados com o coordenador de outro curso de licenciatura. E um dos coordenadores encaminhou as perguntas diretamente ao docente responsável pela disciplina facilitando, posteriormente, o contato com este docente para próxima etapa da pesquisa.

$\mathrm{Na}$ ocasião desses acontecimentos me questionei: Qual seria o envolvimento e o conhecimento dos coordenadores sobre a disciplina Libras nos cursos de licenciatura em que eram responsáveis?

Mas, após a análise dos dados, alguns docentes revelaram alguns enunciados que permeiam esse questionamento e que o leitor terá acesso no próximo capítulo na seção que trata da institucionalização da disciplina Libras na IES.

Retomando os procedimentos metodológicos, em um segundo momento solicitei aos coordenadores que atenderam ao contato inicial, a autorização (Apêndice A) para o acesso aos planos de ensino, quando estes não estavam disponibilizados publicamente, e o contato dos docentes responsáveis pela disciplina para envio do questionário. Nessa etapa, houve certa diminuição no retorno dos coordenadores. Alguns disseram que concordavam com a realização da pesquisa e que conversariam com os docentes, porém não retornavam com o posicionamento e/ou contato dos mesmos, dificultando o processo de coleta de dados.

Dos coordenadores que retornaram com aval positivo para realização da pesquisa fornecendo os e-mails (endereço eletrônico) dos docentes responsáveis pela disciplina, ao entrar em contato com os mesmos tive outros entraves na disponibilidade de alguns para coleta das informações e o acesso ao plano de ensino pessoalmente, apesar de demonstrarem interesse em participar.

Diante dessa situação sugeri aos docentes a opção de enviarem os planos de ensino e o questionário (Apêndices B e C) com os dados referentes ao perfil docente e prática na disciplina via $e$-mail. Com essa alternativa houve concordância e retorno relativamente rápido das informações solicitadas. 
5.4 Docentes participantes da pesquisa

Obtive a adesão de seis docentes na pesquisa e cinco enviaram os dados via $e$-mail e com uma docente realizei a coleta de dados pessoalmente com o registro em áudio (Apêndice D), já que a pessoa era ouvinte. Nesta última forma de coleta, posteriormente, transcrevi e registrei as informações no mesmo questionário utilizado com os demais participantes.

Ressalto o fato de que, apesar do envio e recepção do questionário ter ocorrido, predominantemente, por e-mail, tive a oportunidade de estabelecer o contato pessoal e informal, antes da coleta das informações, com quatro docentes, e após o envio e recepção do questionário me encontrei com uma docente com quem não havia conversado pessoalmente antes. Dessa forma, só não conheci diretamente um dos participantes.

Nessas ocasiões informais conversamos brevemente sobre o intuito da pesquisa e com alguns a conversar também recaiu sobre aspectos que complementaram os dados coletados formalmente, bem como sobre a experiência que eles têm vivenciado nas IES, na prática pedagógica da disciplina e com a comunidade acadêmica.

Outro fato relevante a ser mencionado é que dentre as IES pesquisadas, encontrei apenas uma cujo docente responsável pela disciplina era surdo. No entanto, apesar da aceitação favorável da coordenação do curso de licenciatura, da intermediação e insistência da mesma para que o docente participasse da pesquisa, este optou por não participar no momento.

Com a finalização da descrição dos percursos investigativos a seguir, no último capítulo desta dissertação, me concentrarei na discussão dos dados coletados. 


\section{A CULTURA SURDA NOS CURSOS DE LICENCIATURA: PRÁticAS E PERSPECTIVAS NO ENSINO DA LÍNGUA BRASILEIRA DE SINAIS}

Para finalizar a presente pesquisa este capítulo será dedicado à discussão dos dados coletados com seis docentes da disciplina Libras (Apêndice E) ${ }^{14}$, de IES públicas e privadas localizadas na cidade de São Paulo e na região metropolitana, complementados pelos dados contidos nos planos de ensino disponibilizados por esses mesmos docentes.

A análise dos dados ocorreu por meio do estabelecimento de categorias analíticas, conforme os preceitos de Bogdan e Biklen (1994), e da identificação de regularidades nos enunciados (FOUCAULT, 2013b), conforme emergiam das exposições dos docentes e das descrições contidas nos planos de ensino da disciplina. Delimitando, dessa forma, o campo discursivo que permeia a Libras na grade curricular dos cursos superiores de licenciatura, em consonância com os autores que compuseram a fundamentação teórica deste estudo.

Para tanto, organizei o capítulo em cinco temáticas principais: a primeira "Os sujeitos do discurso" apresento o perfil dos docentes da disciplina Libras, dialogando com documentos legais e pesquisas recentes que discorrem sobre tais profissionais; a segunda, “Institucionalização da disciplina Libras nas IES”, como o próprio título sugere, abordo os dados que se referem ao processo de institucionalização da Libras no Ensino Superior, no entanto, o foco não será rigorosamente burocrático, pois priorizei as impressões dos docentes sobre a receptividade, da disciplina, no meio acadêmico; na terceira parte "Práticas pedagógicas" trato dos aspectos que concernem ao que tem sido proposto e desenvolvido nas aulas da disciplina Libras e que foram descritos pelos docentes e/ou que estavam presentes nos planos de ensino; em seguida "Abordagens sobre a cultura surda" indico as questões que perfazem o cenário discursivo sobre a cultura surda nas aulas; e por último " $A$ permeabilidade dos discursos docentes" contemplo as observações dos docentes sobre as diferentes percepções demonstradas pelos discentes, no contexto das práticas discursivas empreendidas na disciplina.

\footnotetext{
${ }^{14}$ No "Apêndice E" consta a transcrição dos dados dos enunciados docentes que emergiram dos questionários para composição das categorias temáticas analisadas neste capítulo.
} 
6.1 Os sujeitos do discurso

A seguir, descreverei o perfil de cada docente no que se refere: à formação acadêmica; à aquisição/aprendizagem e desenvolvimento da Libras; às experiências na área da surdez e Libras; aos cursos de licenciatura que ministram as aulas de Libras; e ao período de atuação na disciplina nas IES pesquisadas.

Para preservar as identidades dos docentes adotei os seguintes nomes fictícios: Ana, Bruno, Carla, Daniela, Emília e Flávia.

\section{Ana}

Ouvinte. Graduada em Artes Visuais, especialista em Educação de Surdos. Não possui certificação no exame de proficiência em Libras (Prolibras). Ministra a disciplina nos cursos de licenciatura em Pedagogia há seis meses na IES pesquisada.

- Processo de aquisição/aprendizagem e desenvolvimento da Libras:

"Primeiramente com uma educadora surda, de cuja equipe fui estagiária num museu e posteriormente em cursos. O primeiro contato foi em 2008, ou seja, há 4 anos”.

- Experiências na área da surdez e Libras:

“Atendimento Educacional Especializado em museus e espaços culturais (2008-2010), coordenação do curso de Libras para funcionários de museu (2009), atuação como docente (disciplina: Artes) em escola bilingue para surdos (desde 2012) e docência no ensino superior [disciplina Libras] (2012)”.

\section{Bruno}

Ouvinte, filho de pais surdos (CODA) e casado com uma surda. Graduado em Jornalismo e Letras Português/Inglês, especialista em Docência no Ensino Superior e cursa o mestrado em Educação com pesquisa na área da surdez. Certificado no exame de proficiência em Libras (Prolibras) nas categorias tradutor-intérprete de Libras-Língua Portuguesa no Ensino Médio, uso e ensino da Libras no Ensino Médio, uso e ensino da Libras no Ensino Superior. Ministrou a disciplina como optativa a partir de 2006 e, a partir de 2009, quando foi inserida nos cursos de licenciatura em Pedagogia, Letras e Ciências Biológicas. De 2006 a 2010 era o instrutor de Libras em parceria com uma docente responsável pela disciplina, e desde 2010 atua como docente da disciplina na IES pesquisada. 
- Processo de aquisição/aprendizagem e desenvolvimento da Libras:

"Meus pais são surdos, mas não conheciam a Libras e se utilizavam dos sinais chamados 'caseiros'. Com vinte anos de idade aprendi o vocabulário da Libras, pois a estrutura da língua eu já havia internalizado por conta da convivência com meus pais. Fiz um curso em uma Igreja Batista [...] e nos estágios de interpretação conheci a minha atual esposa, que também é surda. Depois comecei a atuar como intérprete em minha igreja [...] e logo ingressei em uma faculdade em São Paulo com esta função. Depois fui contratado pela Universidade [...] [citou a IES pesquisada] como intérprete e instrutor de Libras, local em que fiz o curso de jornalismo. Depois de formado continuei atuando como intérprete e depois como professor. Hoje atuo, exclusivamente, como professor. Meu contato com os surdos é diário".

- Experiências na área da surdez e Libras:

"Atuo como intérprete de Libras em igrejas e também como freelancer. Atuei por muito tempo como intérprete. Além dos cursos licenciatura (Pedagogia e Letras), ministro aulas de Libras [...] nos diversos cursos da Universidade [...] [citou a IES pesquisada] como disciplina optativa. Também atuo no Centro de Línguas da [citou a IES pesquisada], onde Libras é um dos cursos".

\section{Carla}

Ouvinte. Graduada em Pedagogia com habilitação em deficiência auditiva, mestre em Educação Especial e cursa o doutorado em Educação na área da Educação Especial. Não possui certificação no exame de proficiência em Libras (Prolibras). Ministra a disciplina no curso de licenciatura em Pedagogia há dois anos na IES pesquisada.

- Processo de aquisição/aprendizagem e desenvolvimento da Libras:

"Cursos de Extensão, graduação, amigos e comunidade surda. Contato com a Libras há nove anos".

- Experiências na área da surdez e Libras:

“Acompanhamento e orientação a atividades pedagógicas para surdos, crianças e adultos (atual), cursos de extensão (anterior), aulas em especializações sobre Libras (atual), desenvolvimento de um projeto de extensão, pesquisa e ensino sobre contação de histórias em Libras e Língua Portuguesa para crianças surdas e ouvintes em contextos de inclusão na Educação Infantil (atual), aulas em cursos de licenciatura diversos (anterior), aulas no curso de Pedagogia (atual), grupo de estudos sobre a literatura infantil e educação de surdos 
(atual), orientação de Trabalhos de Conclusão de Curso e Iniciação Científica (anterior e atual), supervisão no Programa de Residência Pedagógica em Educação Infantil no curso de Pedagogia (atual)”.

\section{Daniela}

Ouvinte. Graduada em Pedagogia cujo foco era a especialização em formação de professores para Educação Especial em Deficiência Mental e Deficiência da Audiocomunicação. Mestre e doutora em Artes com pesquisas relacionadas à área da surdez. Certificada no exame de proficiência em Libras (Prolibras) na categoria tradutor-intérprete de Libras-Língua Portuguesa no Ensino Superior. Ministra a disciplina Libras no curso de licenciatura em Pedagogia há um bimestre letivo na IES pesquisada.

- Processo de aquisição/aprendizagem e desenvolvimento da Libras:

"Participei em um curso de Libras, como voluntária, e esse curso era ministrado por uma surda e dei continuidade. Terminei o magistério e após o curso procurei trabalho em escolas especiais para surdos, me interessei pela graduação, porque na escola tinha professores formados, e prestei vestibular para educação especial, mas também atuei com Deficientes Mentais".

"O desenvolvimento aconteceu com o contato com usuários de Libras, fazendo outros cursos relacionados à surdez, de forma geral, e de Libras, desde 1989-1990. Também desenvolvi a língua frequentando igrejas e associações. Atualmente, tenho menos contato, mas ainda atuo, esporadicamente, como intérprete ou palestrante e tenho contato com amigos surdos".

- Experiências na área da surdez e Libras:

“Atuei como professora em escola de surdos, intérprete, coordenadora de programa para inserção no mundo do trabalho, ministrante de curso de Libras para funcionários da prefeitura, isto no início da minha vida profissional. Depois ministrei disciplina relacionada à educação especial [...] [citou uma IES privada que não é a pesquisada], em cursos de educação especial (2000-2005), depois na Pedagogia. Quando surgiu a Libras na [...] [citou a mesma IES] ministrei cursos de extensão e a disciplina Libras no curso de Pedagogia. Trabalhei quase 13 anos [...] [citou a mesma IES]. Também ministrei aulas em outras faculdades na área de educação especial e em Libras”.

\section{Emília}

Ouvinte. Fonoaudióloga. Especialista em Intervenção em Deficiência Visual e Surdez. Mestre em Educação na área de Psicologia da Educação. Cursa o doutorado em Educação na 
área de Sociologia da Educação. Certificada no exame de proficiência em Libras (Prolibras) na categoria tradutor-intérprete no Ensino Superior. Ministra a disciplina no curso de licenciatura em História, Letras, Ciências Sociais e Filosofia há um semestre na IES pesquisada.

- Processo de aquisição/aprendizagem e desenvolvimento da Libras:

"A aquisição da Libras ocorreu em alguns cursos básicos ministrados por surdos e através do contato com surdos durante a atuação profissional. Há, aproximadamente, 20 anos tenho contato com a Libras".

- Experiências na área da surdez e Libras:

"Atendimento fonoaudiológico de estímulo de língua e linguagem da Língua Brasileira de Sinais, experiência anterior (em curso) em interpretação, no $2^{\circ}$ semestre de 2012 a docência da disciplina Libras, com experiência de 4 anos em outros cursos na mesma disciplina”.

\section{Flávia}

Ouvinte. Pedagoga com habilitação em Distúrbios da Comunicação. Mestre em Distúrbios da Comunicação Humana. Não possui certificação no exame de proficiência em Libras (Prolibras). Ministra a disciplina no curso de licenciatura em Pedagogia, Letras, História e Geografia, e no curso de Psicologia, há seis anos na IES pesquisada.

- Processo de aquisição e desenvolvimento da Libras:

"Tenho contato com surdos há 26 anos, por meio da minha profissão, aprendi a Libras com os próprios surdos e depois fiz vários cursos inclusive de proficiência em Língua de Sinais”.

- Experiências na área da surdez e Libras:

"Dei aula para crianças surdas, aproximadamente, durante 18 anos, fui professora de ensino fundamental I ( $1^{\circ}$ ao $4^{\circ}$ ano), dei aulas de leitura, e fiz muitas traduções de palestras para surdos adultos. Hoje coordeno um setor de educação inclusiva [...] e tenho contato com surdos que trabalham conosco, bem como na universidade eu trabalho em conjunto com um professor surdo para ministrar Libras".

Diante dos dados sobre os perfis docentes sintetizei algumas informações no quadro que consta abaixo. 
Quadro dos perfis docentes

\begin{tabular}{|c|c|c|c|c|}
\hline DOCENTE & GRADUAÇÃO & $\begin{array}{c}\text { PÓS- } \\
\text { GRADUAÇÃO }\end{array}$ & PROLIBRAS & $\begin{array}{c}\text { DESENVOLVIMENTO } \\
\text { DA LIBRAS }\end{array}$ \\
\hline $\begin{array}{l}\text { ANA } \\
\text { Ouvinte }\end{array}$ & Artes Visuais & $\begin{array}{l}\text { Especialização } \\
\text { em Educação de } \\
\text { Surdos }\end{array}$ & $\begin{array}{l}\text { Sem } \\
\text { certificação }\end{array}$ & $\begin{array}{l}\text { Contato com educadora } \\
\text { surda no estágio em } \\
\text { museu } \\
\text { Cursos }\end{array}$ \\
\hline $\begin{array}{l}\text { BRUNO } \\
\text { Ouvinte } \\
\text { CODA }\end{array}$ & $\begin{array}{l}\text { Jornalismo } \\
\text { Letras } \\
\text { Português- } \\
\text { Inglês }\end{array}$ & $\begin{array}{l}\text { Especialização } \\
\text { em Docência no } \\
\text { Ensino Superior } \\
\text { Mestrado em } \\
\text { Educação } \\
\text { (cursando) }\end{array}$ & $\begin{array}{l}\text { Certificação } \\
\text { nas } \\
\text { categorias: } \\
\text { tradutor- } \\
\text { intérprete e } \\
\text { ensino de } \\
\text { Libras }\end{array}$ & $\begin{array}{l}\text { Contato com os pais } \\
\text { surdos } \\
\text { Estágio de interpretação } \\
\text { Esposa surda } \\
\text { Cursos }\end{array}$ \\
\hline $\begin{array}{l}\text { CARLA } \\
\text { Ouvinte }\end{array}$ & $\begin{array}{l}\text { Pedagogia com } \\
\text { habilitação em } \\
\text { deficiência } \\
\text { auditiva }\end{array}$ & $\begin{array}{l}\text { Mestrado em } \\
\text { Educação } \\
\text { Especial } \\
\text { Doutorado em } \\
\text { Educação } \\
\text { (cursando) }\end{array}$ & $\begin{array}{l}\text { Sem } \\
\text { certificação }\end{array}$ & $\begin{array}{l}\text { Cursos } \\
\text { Amigos } \\
\text { Comunidade surda }\end{array}$ \\
\hline $\begin{array}{l}\text { DANIELA } \\
\text { Ouvinte }\end{array}$ & $\begin{array}{l}\text { Pedagogia com } \\
\text { formação em } \\
\text { educação } \\
\text { especial na área } \\
\text { da deficiência } \\
\text { mental e } \\
\text { deficiência } \\
\text { auditiva }\end{array}$ & $\begin{array}{l}\text { Mestrado e } \\
\text { Doutorado em } \\
\text { Artes Visuais }\end{array}$ & $\begin{array}{l}\text { Certificação } \\
\text { na categoria } \\
\text { tradutor- } \\
\text { intérprete }\end{array}$ & $\begin{array}{l}\text { Cursos } \\
\text { Contato com surdos em } \\
\text { igrejas e associações } \\
\text { Amigos surdos }\end{array}$ \\
\hline $\begin{array}{l}\text { EMÍLIA } \\
\text { Ouvinte }\end{array}$ & Fonoaudiologia & $\begin{array}{l}\text { Especialização } \\
\text { em Intervenção } \\
\text { em Deficiência } \\
\text { Visual e Surdez } \\
\text { Mestrado em } \\
\text { Educação e } \\
\text { Doutorado em } \\
\text { Educação } \\
\text { (cursando) }\end{array}$ & $\begin{array}{l}\text { Certificação } \\
\text { na categoria } \\
\text { tradutor- } \\
\text { intérprete }\end{array}$ & $\begin{array}{l}\text { Cursos } \\
\text { Contato com surdos no } \\
\text { trabalho }\end{array}$ \\
\hline $\begin{array}{l}\text { FLÁVIA } \\
\text { Ouvinte }\end{array}$ & $\begin{array}{l}\text { Pedagogia com } \\
\text { habilitação em } \\
\text { distúrbios da } \\
\text { comunicação }\end{array}$ & $\begin{array}{l}\text { Mestrado em } \\
\text { Distúrbios da } \\
\text { Comunicação } \\
\text { Humana }\end{array}$ & $\begin{array}{l}\text { Sem } \\
\text { certificação }\end{array}$ & $\begin{array}{l}\text { Cursos } \\
\text { Contato com surdos no } \\
\text { trabalho }\end{array}$ \\
\hline
\end{tabular}


Para delinear os perfis dos sujeitos do discurso responsáveis pela docência da disciplina Libras, verifica-se que o primeiro dado relevante é o fato de todos serem ouvintes, pois durante a pesquisa tive dificuldade em encontrar docentes surdos nas IES que estabeleci contato, conforme descrevi no capítulo que concerne ao percurso investigativo.

No entanto, dentre os participantes, o docente Bruno, além de ser CODA, também é casado com uma pessoa surda, demonstrando uma relação próxima e constante com membros da comunidade surda e com a língua de sinais. O que o diferencia dos demais participantes da pesquisa em termos linguísticos, identitários e culturais, pois como ele mesmo afirma: "Meus pais são surdos, mas não conheciam a Libras e se utilizavam dos sinais chamados 'caseiros'. Com vinte anos de idade aprendi o vocabulário da Libras, pois a estrutura da língua eu já havia internalizado por conta da convivência com meus pais.[...] Meu contato com os surdos é diário."

Os "sinais caseiros" ou "sinais emergentes" que Bruno cita, são descritos por Strobel (2008) como sinais produzidos por surdos que moram em regiões rurais, vivem isolados, ou não estabeleceram o contato com outros membros das comunidades surdas e, a partir de suas experiências visuais, criam sinais ou utilizam "gestos" indicativos consonantes com sua rotina diária.

Retomando a discussão do fato dos docentes serem ouvintes, no Decreto $n^{\circ}$ 5.626/05 fica explícita a preferência dada aos docentes surdos na disciplina. Mas, o mesmo documento não exclui a atuação de ouvintes como responsáveis pelas aulas, conforme a redação presente no artigo $7^{\circ}$, ao considerar a hipótese de falta de profissionais com graduação ou pósgraduação em Libras oferece três possibilidades de formação, sendo elas:

I - professor de Libras usuário dessa língua com curso de pós-graduação ou com formação superior e certificado de proficiência em Libras, obtido por meio de exame promovido pelo Ministério da Educação;

II - instrutor de Libras, usuário dessa língua com formação em nível médio e com certificado obtido por meio de exame de proficiência em Libras, promovido pelo Ministério da Educação;

III - professor ouvinte bilíngue: Libras - Língua Portuguesa, com pós-graduação ou formação superior e com certificado obtido por meio de exame de proficiência em Libras, promovido pelo Ministério da Educação. (BRASIL, 2005, grifo meu).

A pesquisa de Rebouças (2009) defende, enfaticamente, a presença de docentes surdos como responsáveis pela disciplina Libras, inclusive, mencionando que os ouvintes estão ocupando a função de trabalho dos surdos e que as IES são responsáveis por essa situação.

Muitas IES evitam a contratação de surdos com o argumento de que não querem o trabalho de pessoas que não tenham o diploma de nível superior, o que fere o direito dos instrutores de nível médio. Este contexto também favorece o 
preenchimento indevido de postos de trabalho por ouvintes diplomados, mas nem sempre fluentes. (REBOUÇAS, 2009, p. 115, grifo da autora).

A citação de outros autores, que já mencionei no capítulo "Língua de Sinais”, traz um trecho condizente com Rebouças (2009) ao afirmar que: “[...] o poder nas escolas e nas classes de surdos continua nas mãos dos ouvintes e que se pensa nos surdos apenas como instrutores de língua de sinais, ainda assim, substituíveis por ouvintes que, muitas vezes, dominam muito mal essa língua [...]" (RANGEL; STUMPF, 2012, p.119).

Rebouças (2009) toma com princípio uma parte da norma estabelecida pela legislação e ao mesmo tempo refuta outra, pois "o preenchimento indevido de postos de trabalho por ouvintes", não é indevido perante o Decreto. Mas, nas comunidades surdas circulam enunciados que defendem a atuação somente de profissionais surdos não somente na disciplina de Libras, mas também em cursos livres dessa língua voltados para ouvintes e, sobretudo, nas escolas que tem alunos surdos, conforme se aplica o contexto da citação de Rangel e Stumpf (2012) que, igualmente, enfatiza a preocupação com a proficiência em Libras pelos ouvintes.

Nos enunciados há uma "desconfiança" sobre o domínio linguístico das pessoas ouvintes com relação a Libras. Entretanto, quando considero os docentes que participaram desta pesquisa, o menor tempo de contato com a Libras de um deles é de quatro anos. E, a maioria, ao longo da vida pessoal, acadêmica e profissional mencionaram o compromisso estabelecido, em suas relações familiares e de amizade, estudos, pesquisas e vínculos empregatícios, com os surdos e a Libras há mais de vinte anos, como demonstram os docentes Bruno, Daniela, Emília e Flávia.

No que tange à formação dos docentes, os mesmos se vincularam aos diferentes cursos de graduação, em especial, aos cursos de licenciatura como Artes, Letras e Pedagogia. Este último, além de ser o curso de formação de três docentes, em todos os casos, aparece com a especificidade de ter sido voltado para educação de surdos, como é o caso das docentes Carla, Daniela e Flávia.

A Pedagogia com habilitação, em diferentes áreas da Educação e da Educação Especial, era comum antes da implementação das propostas de educação inclusiva e das Diretrizes Curriculares para o Curso de Pedagogia (BRASIL, 2006) que demandam a reformulação da grade curricular do referido curso, conforme apontam Vitaliano et. al. (2012). As autoras analisaram a nova organização das grades curriculares dos cursos de Pedagogia de IES do Estado do Paraná e São Paulo, a fim de atender a formação de 
pedagogos para o atendimento de alunos com Necessidades Educacionais Especiais (NEE) no contexto da educação inclusiva:

[...] os dados obtidos evidenciaram que todas as IES apresentam na grade curricular do curso de Pedagogia, pelo menos uma disciplina que tem como foco análises sobre $o$ atendimento educacional de alunos com NEE. Alguns cursos acrescentam conteúdos a respeito em outras disciplinas o que indica que estamos em processo de considerar que a população que apresenta NEE, também deve ser alvo da área da Educação. Muito embora algumas ementas contemplem termos que nos remete ainda a uma perspectiva segregada da Educação Especial. (VITALIANO et. al., 2012, p. 24).

Foi nessa mesma época, de reestruturação da grade curricular do curso de Pedagogia, que a disciplina Libras começou a ser inserida nos cursos de licenciatura. Dessa forma, instaurou-se em várias IES certa "separação" entre o campo da Libras e da educação de surdos, do campo que compreende as demandas gerais dos alunos considerados com NEE. Ao mesmo tempo, a formação durante a graduação de educadores habilitados para o ensino de surdos, pessoas com cegueira ou baixa-visão, deficiência intelectual, mobilidade reduzida, entre outras, começaram a ser ofertadas em cursos de especialização, em nível de pósgraduação lato sensu, com a finalidade de formar especialistas em diferentes subáreas da educação. E, não destinados, exclusivamente, aos licenciados em Pedagogia, mas para qualquer egresso dos cursos de graduação.

Dentre os cursos de bacharelado que aparecem na formação dos docentes participantes consta, Jornalismo, como um dos cursos de formação do docente Bruno, lembrando que ele também é formado em Letras, e o de Fonoaudiologia cursado pela docente Emília.

Dessa maneira, pode-se apontar que o primeiro curso de graduação da maioria dos docentes já estava relacionado à área da surdez, como os cursos de Fonoaudiologia e Pedagogia com habilitação em educação de surdos ou deficiência auditiva, ou com a denominação habilitação em distúrbios da comunicação. Além disso, a docente Ana, graduada em Artes, se especializou, posteriormente, em educação de surdos em curso de pós-graduação lato sensu.

No tocante as atuações profissionais relatadas a de Tils fez - ou faz - parte do trabalho desempenhado por Bruno, Daniela, Emília e Flávia.

Apesar da regulamentação recente dessa profissão, pela Lei Federal no 12.319, de 1 de setembro de 2010 (BRASIL, 2010), a mesma já era exercida por pessoas que, por razões pessoais, familiares, religiosas e profissionais, optaram por mediar a comunicação entre a comunidade surda e a comunidade ouvinte, inclusive, em muitas situações de forma 
voluntária. Por isso, ainda é comum encontrarmos Tils com formação e trabalho, paralelo, em outras profissões. De acordo com Rosa (2003, p. 242):

O intérprete de Língua de Sinais geralmente é formado nas associações de surdos, com os quais tem convívio quase diário, criando um vínculo afetivo muito forte. Portanto, o ato interpretativo enlaça uma relação afetiva com a comunidade surda, isto é, a completude da mensagem a ser interpretada não será determinada somente pela fluência na Língua de Sinais.

Atualmente, essas pessoas têm sido cada vez mais requisitadas profissionalmente em ambientes religiosos e educacionais como já ocorria tradicionalmente e têm se expandido para ambientes das áreas da saúde, empresarias, eventos, jurídicos, culturais, prestação de serviços, entre outras.

Outras funções desempenhadas comumente pelos docentes consistem no trabalho como professor de surdos e como ministrante ou coordenador de cursos sobre educação de surdos e Libras não apenas em cursos cujo público são licenciados, mas também em cursos que atingem outros profissionais.

Tendo como princípio que:

Todo enunciado é portador de uma certa regularidade e não pode dela ser dissociado. Não se deve, portanto, opor a regularidade de um enunciado à irregularidade de outro (que seria menos esperado, mais singular, mais rico em inovações), mas sim a outras regularidades que caracterizam outros enunciados. (FOUCAULT, 2013b, p. 176).

Considerando o enunciado mais singular citado por Foucault (2013b), destaco as funções que não foram recorrentes entre os docentes, como a estimulação da língua e linguagem em Libras na área de fonoaudiologia pela docente Emília, e o atendimento educacional especializado em museus e espaços culturais como o realizado pela docente Ana. Esses campos de atuação demonstram mudanças e avanços nos atendimentos almejados pelas comunidades surdas e podem ser localizados no que tange ao respeito à diferença linguística e a promoção da acessibilidade cultural.

A formação em fonoaudiologia não é uma profissão "relativamente recente", mas é uma área que focou, inicialmente, no processo de reabilitação clínica e terapêutica de surdos e o estímulo à linguagem e língua tendo como princípio as línguas orais, no caso do Brasil, a Língua Portuguesa, e ainda hoje, algumas vertentes defendem e empregam ações na perspectiva, exclusivamente, oral.

Em contrapartida, outras vertentes tem se encaminhado para o atendimento às necessidades dos surdos enfatizando, principalmente, sua condição natural de comunicação e 
estruturação da linguagem por meio de línguas visual-motoras, fato que vai de encontro com a normalidade sociocomunicativa pautada no ouvinte, conforme descreve Cruz (2011, p. 31):

\begin{abstract}
Atualmente, alguns fonoaudiólogos realizam o atendimento fonoaudiológico com crianças surdas em uma abordagem bilíngue, utilizando a língua de sinais com o objetivo de a criança ter oportunidade de adquirir a linguagem de forma esperada ou para tratar de atrasos linguísticos em sua primeira língua, antes de ela iniciar a aprendizagem de uma segunda língua (oral e/ou escrita).
\end{abstract}

Já na área de atuação da docente Ana nota-se que os espaços culturais começam a se preocupar com o atendimento ao público surdo. Na cidade de São Paulo tem se tornado mais comum a presença de Tils em peças de teatro e em espaços culturais, e de arte-educadores, surdos ou ouvintes fluentes em Libras em museus como ocorre, por exemplo, no Museu de Arte Moderna, Museu Afro, Itaú Cultural, dentre outros.

De acordo com Strobel (2008, p. 66) "tem muitos surdos artistas que fazem desenhos, pinturas, esculturas e outras manifestações artísticas com a extensão da beleza, equilíbrio, harmonia e revoltas com muitas discriminações sofridas", e além de produzirem arte, os surdos podem apreciar a mesma, seja ela produzida por suas comunidades ou por artistas ouvintes, contando com a viabilização da comunicação em língua de sinais.

No que diz respeito à formação específica em Libras, houve recorrência em cursos promovidos institucionalmente e por meio do contato direto com usuários da língua de sinais. Esse contato, em alguns lugares ou situações, era a única ou predominante forma dos ouvintes aprenderem ou se aprofundarem no uso da Libras, até alguns anos atrás, conforme lembra Gesser (2012, p. 76):

A urgência em se comunicar (para fins profissionais, educacionais ou pessoais) e a carência de contextos formais para o ensino de Libras fizeram com que o encontro com um surdo sinalizador funcionasse como a única "escola" para se aprender sinais. A validade desses encontros é inquestionável. Todo aluno participante de um curso formal de aprendizagem de Libras tem também de ter a oportunidade de interagir com outros surdos para além das paredes da sala de aula.

Outro fato que pode ser mencionado é que nenhum dos participantes se formou no curso de Letras-Libras ou cursos de especialização em nível pós-graduação em Libras, conforme o previsto no Decreto $n^{0}$ 5.626/05. Porém, três participantes atendem a aprovação no exame de certificação de proficiência em Libras do MEC, o Prolibras, que também é uma norma prevista no referido texto legal.

O exame Prolibras reflete a emergência de uma normatividade específica para a comprovação da proficiência em língua de sinais ao certificar os usuários da Libras durante o 
período de formação de profissionais em cursos como o de Letras-Libras ou de pós-graduação em Libras.

Quadros et. al. (2009, p. 29), descrevem quais são as pessoas que podem se inscrever no exame: "profissionais (surdos e ouvintes) com nível médio completo ou superior completo, que possuam conhecimentos sobre o uso e o ensino da Língua Brasileira de Sinais - Libras ou sobre Tradução e Interpretação da Libras/Língua Portuguesa”. E dentre os requisitos para proficiência em Libras, ou seja, para aqueles que ministrarão as aulas, são:

a) Formação de nível superior, fluente, em Libras, com habilidades metodológicas, didático-pedagógicas para a função de professor de Libras; ou

b) Formação de nível médio completo, fluente em Libras, com habilidades metodológicas, didático-pedagógicas para a função de instrutor de Libras. (QUADROS, et. al., 2009, p. 29).

Os autores também expõem os requisitos para o exame de tradução e interpretação que são:

a) Formação de nível superior, com competência para realizar a interpretação das duas línguas de maneira simultânea ou consecutiva;

b) Formação de nível médio completo, competência para realizar a interpretação de textos, palestras, conferências, discursos, eventos, aulas, atividades didáticopedagógicas e outras. (QUADROS, et. al., 2009, p. 29).

De acordo com as descrições dos docentes, a Daniela e a Emília foram aprovadas e certificadas de acordo com a normatividade expressa no requisito "a" de tradutores e intérpretes, e o docente Bruno, além de atender ao requisito "a" da mesma categoria das outras duas docentes, foi certificado nos requisitos "a" e "b" da categoria de ensino da Libras.

Tal fato evidencia que as IES nas quais os docentes ministram as aulas, no processo de contração/aprovação dos candidatos à docência de Libras, não levaram em consideração, necessariamente, as normas dispostas na legislação, com exceção da IES do docente Bruno. Pois, como ele mesmo relata, antes de assumir a responsabilidade como docente da disciplina, atuou como instrutor de Libras em parceria com outra docente quando ainda não havia concluído a graduação, logo, não recebera a certificação para ensino da Libras em nível superior.

Nesse sentido, diante dos dados expostos, pode-se supor que as demais IES devem ter observado outros aspectos no currículo de cada um dos docentes, em especial, os cursos que realizaram e ministraram e a experiência que têm na área da surdez e Libras. Além da adoção de procedimentos de contração/aprovação de candidatos coerentes com as normatividades institucionais internas. 
6.2 A institucionalização da disciplina Libras nas IES

A presente seção contará com os dados que se referem à institucionalização da disciplina Libras nas IES pesquisadas. Para tanto, descreverei e discutirei o tipo de IES em que os docentes atuam (pública ou privada), os cursos que ministram as aulas, o período de docência na disciplina e a carga horária destinada à mesma. Logo após, estará a discussão sobre os enunciados que tematizam a reação da comunidade acadêmica frente à inclusão/inserção da disciplina nas IES.

Ressalto que meu objetivo não recairá no detalhamento das IES, para que a identificação das instituições e dos docentes seja preservada, muito menos na institucionalização estritamente burocrática e específica da disciplina. A preocupação, a priori, será com os aspectos perceptivos sobre a receptividade da disciplina no meio acadêmico.

Logo abaixo consta um quadro que sintetiza as informações prestadas por cada docente, complementadas pelos dados do plano de ensino no que concerne ao tipo de instituição, período de docência dos participantes nas IES pesquisadas, os cursos de licenciatura que ministram as aulas e a carga horária destinada para cada curso. 
Quadro da disciplina Libras nas IES: docência, cursos de licenciatura e carga horária

\begin{tabular}{|c|c|c|c|c|}
\hline DOCENTE & $\begin{array}{c}\text { TIPO DE } \\
\text { INSTITUIÇÃO } \\
\text { DE ENSINO } \\
\text { SUPERIOR }\end{array}$ & $\begin{array}{c}\text { TEMPO QUE } \\
\text { MINISTRA A } \\
\text { DISCIPLINA } \\
\text { NA IES }\end{array}$ & $\begin{array}{l}\text { CURSOS QUE } \\
\text { MINISTRA A } \\
\text { DISCIPLINA }\end{array}$ & $\begin{array}{c}\text { CARGA } \\
\text { HORÁRIA DA } \\
\text { DISCIPLINA }\end{array}$ \\
\hline ANA & Privada & Um semestre & Pedagogia & $66 \mathrm{~h} / \mathrm{a}$ \\
\hline BRUNO & Privada & $\begin{array}{l}\text { Quatro anos } \\
\text { como instrutor } \\
\text { Dois anos como } \\
\text { docente }\end{array}$ & $\begin{array}{l}\text { Pedagogia } \\
\text { Letras } \\
\text { Ciências } \\
\text { Biológicas } \\
\text { Educação Física }\end{array}$ & $40 \mathrm{~h} / \mathrm{a}$ \\
\hline CARLA & Pública & Dois anos & Pedagogia & $75 \mathrm{~h} / \mathrm{a}$ \\
\hline DANIELA & Pública & Um bimestre & Pedagogia & $60 \mathrm{~h} / \mathrm{a}$ \\
\hline EMÍLIA & Pública & Um semestre & $\begin{array}{l}\text { História } \\
\text { Letras } \\
\text { Ciências Sociais } \\
\text { Filosofia }\end{array}$ & $30 \mathrm{~h} / \mathrm{a}$ \\
\hline FLÁVIA & Privada & Seis anos & $\begin{array}{l}\text { Pedagogia } \\
\text { Letras } \\
\text { História } \\
\text { Geografia } \\
\text { Psicologia }\end{array}$ & $\begin{array}{l}96 \mathrm{~h} / \mathrm{a} \\
72 \mathrm{~h} / \mathrm{a} \\
72 \mathrm{~h} / \mathrm{a} \\
72 \mathrm{~h} / \mathrm{a} \\
72 \mathrm{~h} / \mathrm{a}\end{array}$ \\
\hline
\end{tabular}


De acordo com o quadro acima, os dados que se referem ao tipo de instituição que a disciplina Libras foi incluída abrangem tanto IES privadas, como as que atuam as docentes Ana, Bruno e Flávia, quanto públicas, como as que atuam as docentes Carla, Daniela e Emília. Esclareço que as docentes Carla e Emília trabalhavam na mesma instituição, mas estavam vinculadas à diferentes cursos.

A carga horária destinada para a disciplina fica entre o mínimo de 30h/a e o máximo de 96h/a. Ou seja, entre as IES há uma variação muito grande quando se tem como premissa que todos os cursos pesquisados são de licenciatura. Dentro deste intervalo aparecem disciplinas com a carga horária de 36h/a, 40h/a, 60h/a e 75h/a.

Ao comparar a carga horária ao curso que ela se destina, percebe-se que os cursos com menor carga horária são os de História, Geografia, Filosofia, Ciências Sociais e Letras, com 30h/a em uma IES pública, 36 h/a, 40h/a, 72h/a em três IES privadas. E o curso que tem maior carga horária é o de Pedagogia com 40h/a, 60h/a, 66h/a, 75 h/a ou 96h/a nas diferentes IES.

Das IES em que o mesmo docente ministra a disciplina em diferentes cursos de licenciatura, apenas uma mantém a mesma carga horária tanto para o curso de Pedagogia quanto para os demais cursos.

Diante das diversas cargas horárias na disciplina Libras, para aqueles alunos que tiveram uma disciplina com carga horária de $96 \mathrm{~h} / \mathrm{a}$, as possibilidades de desenvolvimento comunicativo na língua de sinais e de compreensão dos aspectos que permeiam a comunidade surda podem ser maiores do que os alunos que tiveram apenas 30h/a.

Nesse sentido, os futuros professores oriundos dos cursos de Pedagogia que, provavelmente, atuarão na Educação Infantil ou no Ensino Fundamental I terão maior contato com os saberes que circulam discursivamente sobre os surdos e a língua de sinais, que os futuros professores responsáveis pelo Ensino Fundamental II e Ensino Médio.

Porém, se considerarmos os predispostos de uma educação bilíngue para alunos surdos e seu vínculo com o discurso da diferença linguística e cultural, todos os professores, independentemente, do nível de ensino e da disciplina do currículo escolar, deveriam ter as mesmas possibilidades de acesso, aprendizagem e desenvolvimento nos aspectos práticos e/ou teóricos contemplados nas aulas para que em suas futuras aulas concentrem-se no compromisso do pleno desenvolvimento do aluno surdo. Conforme defende Dorziat (2009, p. 39): 
de ensino alienantes, que não valorizam a cultura e nem vislumbram um espaço social para essas pessoas. A organização institucional para surdos em torno de ideias pedagógicas consistentes não se caracteriza como uma opção de trabalho. Ela deve ser um compromisso dos que atuam nessa área.

De forma complementar, a atuação dos futuros professores que tiveram uma carga horária reduzida na disciplina Libras pode contribuir para incorporação de práticas discursivas generalizadas sobre os surdos como, por exemplo, citam Lodi, Harrison e Campos (2012, p. 14):

\begin{abstract}
O que observamos é a circulação de discursos que tendem a pressupor que, em sendo surdo, o domínio da Libras é um fato ou que apenas fazem crer uma aceitação de sua existência. Esses discursos em nada modificam as posturas dos ouvintes frente aos surdos e, pior, em situações escolares, mantém-se a valorização da língua portuguesa, seja pelo não uso da Libras ou pela descaracterização da gramática da língua de sinais, realizada por meio da inclusão de aspectos gramaticais do português.
\end{abstract}

Sobre os cursos que os docentes participantes desta pesquisa ministram as aulas de Libras, cinco deles estão vinculados ao curso de Pedagogia e destes, três ministram as aulas, exclusivamente, nesse curso. Fato que pode estar relacionado ao processo de inclusão da disciplina de acordo com a normatividade do Decreto $\mathrm{n}^{\circ} 5.626 / 05$, este estabelece os primeiros cursos que devem incluir a disciplina na grade curricular. De acordo com o parágrafo único do artigo $9^{\circ}$, "o processo de inclusão da Libras como disciplina curricular deve iniciar-se nos cursos de Educação Especial, Fonoaudiologia, Pedagogia e Letras, ampliando-se progressivamente para as demais licenciaturas" (BRASIL, 2005).

Alguns docentes relatam que além dos cursos de licenciatura também ministram as aulas de Libras em outros cursos como disciplina optativa como, por exemplo, no curso de Psicologia, de responsabilidade da docente Flávia. O docente Bruno apesar de não especificar quais são os cursos afirma ministrar a disciplina em caráter também opcional. Tal constatação revela que as prerrogativas do parágrafo $2^{\circ}$ do artigo $3^{\circ}$ do Decreto $n^{\circ}$ 5.626/05 foram atendidas em duas IES pesquisadas, a saber, "a Libras constituir-se-á em disciplina curricular optativa nos demais curso de educação superior e na educação profissional [...]" (BRASIL, 2005).

No que se refere ao tempo que os docentes atuam na disciplina nas IES pesquisadas, observa-se a variação de um período mínimo de um bimestre letivo, como é o caso da docente Daniela, até o período máximo de seis anos, como é o caso da docente Flávia.

Tal dado evidencia que a Libras, enquanto disciplina, ainda encontra-se em processo de consolidação se comparada às disciplinas que compõem, tradicionalmente, a grade 
curricular de qualquer curso de licenciatura. E os docentes ainda podem estar na fase inicial de construção da trajetória profissional na disciplina, quiçá, nos cursos ou na instituição.

Isaia (2000) em seu estudo discutiu a trajetória constitutiva/construída do professor universitário de cursos de licenciatura levando em consideração a relação do percurso pessoal/profissional e aponta que:

[...] as transformações pelas quais passa ao longo da carreira docente estão ligadas a alterações vivenciais mais amplas, envolvendo a dimensão pessoal e profissional. $\mathrm{O}$ professor e a pessoa do professor não podem estar dissociados sob a pena de fragmentar-se a compreensão que dele se possa ter [...]. (ISAIA, 2000, p. 32).

Diante da importância de se considerar o docente como pessoa e profissional, a seguir tratarei das percepções relatadas pelos participantes da pesquisa sobre a inclusão da disciplina Libras e às observações que fizeram sobre a reação que a comunidade acadêmica teve sobre essa recente demanda normativa da área da surdez, no contexto do Ensino Superior.

Os relatos dos docentes compreendem percepções que apontam para as tensões que pairam sobre a presença da disciplina Libras nas IES. No entanto, de forma geral, há uma recorrência sobre o caráter positivo da presença da disciplina, conforme demonstram os trechos abaixo:

"A comunidade acadêmica de forma geral recebeu bem a disciplina e os alunos mostram interesse" Ana.

“Atualmente, atuo apenas no curso de Pedagogia. Meu ingresso no referido curso foi tranquilo, sendo inclusive profissionais vinculados a esse curso que têm defendido a inserção da disciplina de Libras em todos os cursos de licenciaturas” Carla.

"A receptividade foi muito boa, interessante" Daniela.

"[...] os discentes são interessados, produtivos e ativos durante as aulas [...] com os funcionários o contato é bastante cordial e interessado ” Emília.

“Creio que a reação é positiva” Flávia.

Ou seja, apesar de ser uma língua que não fazia parte até pouco tempo atrás do meio acadêmico, a disciplina ao ocupar um determinado espaço no ambiente institucional tem-se tornado mais evidente e/ou aceita gerando, inclusive, novos processos de ampliação sobre a aprendizagem da Libras pelos ouvintes que circulam nas IES. E, dentre esses ouvintes, não há apenas a presença de discentes que a tem como disciplina obrigatória ou opcional, mas outros membros da comunidade acadêmica como, por exemplo, os funcionários e alguns docentes citados nos relatos. 
Essa expansão pode ser exemplificada quando os docentes apontam a criação de cursos de Libras de extensão universitária, cursos de Libras no centro de línguas das instituições e a oferta de cursos voltados para os funcionários da IES. O que, de certa forma, é uma prerrogativa que consta no decreto $\mathrm{n}^{\circ} 5.626 / 05$, mas que depende de interessados nesses tipos de cursos para que haja a implementação efetiva, e esse foi o caso das IES que investiram em ações que difundem a língua de sinais para além da sala de aula de futuros professores ou fonoaudiólogos.

Wilcox e Wilcox (2005) citam que nos Estados Unidos houve uma pesquisa comparativa entre os anos de 1986 e 1991 sobre a procura por cursos de ASL em IES, nos cursos ofertados observa-se que em 1986 o número era de 935 cursos e em 1991 esta quantidade subiu para 2111. Demonstrando que aos poucos a ASL tem sido aceita como língua estrangeira, segundo os autores:

\begin{abstract}
Até pouco tempo atrás, o aumento do interesse sobre a ASL tinha gerado apenas um pequeno impacto na política de línguas estrangeiras dos cursos de terceiro grau. Embora a ASL tenha uma história longa e rica nos EUA e a pesquisa acadêmica sobre a ASL já tenha entrado na sua quarta década, o processo de aceitação da ASL como alternativa para os requerimentos de língua estrangeira tem sido muito lento. Isso também está começando a mudar. A aceitação da ASL como língua estrangeira hoje em dia é um assunto em debate entre diversas faculdades e universidade norteamericanas e também em nossas legislaturas estaduais. (WILCOX; WILCOX, 2005, p. 89).
\end{abstract}

No Brasil, não encontrei estudos que apontam quantitativamente a diferença no aumento da oferta de cursos de Libras, sejam eles de acesso livre ao público e promovidos por associações e igrejas ou oferecidos em ambientes institucionais da área da educação, em especial, no Ensino Superior. Aliás, essa uma sugestão de pesquisa que pode ser desenvolvida e que, provavelmente, trará algumas asserções sobre as dimensões de permeabilidade que a Libras tem tomado em cursos de diferentes níveis e público-alvo.

Retomando a discussão sobre as percepções dos docentes, ao mesmo tempo em que relatam aspectos positivos sobre a inclusão da disciplina Libras nas IES, verifica-se também a alusão aos aspectos que dificultaram - ou dificultam - esse processo.

A obrigatoriedade da disciplina na grade curricular dos cursos de licenciatura, apesar de ser uma normatividade legal, não tem transcorrido burocraticamente de forma uníssona, e não tem sido tacitamente aceita, inicialmente, no meio acadêmico por alguns docentes e coordenadores, como revelam alguns enunciados.

O docente Bruno, por exemplo, faz a alusão da normatividade presente na legislação como a principal responsável pela inserção da disciplina Libras: 
"Percebo que esse despertar foi apenas por força de lei. Antes da lei, não havia preocupação com a inclusão do aluno surdo, que dirá a inserção de uma disciplina que falasse sobre Libras e sobre Surdez. Mas percebi também que após a lei, as instituições perceberam que era um processo importante, que poderia contribuir com a formação dos alunos".

Esse trecho, além de indicar a influência que pode ser atribuída a um texto legal que passa a ser aceito como uma norma no ambiente universitário, também aponta que o discurso proferido pelos profissionais que cumprem essa mesma norma pode gerar novas concepções e atitudes sobre aquilo que antes era "desconhecido" e que aos poucos começa a fazer parte do cotidiano e da realidade institucional.

Souza (2006, p. 267) alerta que:

[...] as leis não mudam as práticas, e garantia de direito não é o mesmo que ter acesso à igualdade de condições. Caberá a nós construirmos práticas outras de transformação da realidade presente e das formas de entendermos o que seja a identidade de um povo, o que não deixa de ser uma das instigantes questões de fundo quando o país reconhece a existência de uma língua brasileira outra que não o português - a língua brasileira de sinais.

No caso, na IES que o docente Bruno atua houve ampliação do conjunto de enunciados que aceitam a Libras institucionalmente, já que o acesso à mesma foi estendido como disciplina optativa aos demais cursos superiores e foi criado um programa de difusão para professores e funcionários. E, a IES da docente Flávia também promoveu cursos de Libras para os funcionários da secretaria.

Essas instituições são privadas e são as que os docentes atuam há mais tempo como responsáveis pela disciplina quando comparados aos demais. Ou seja, eles vivenciam um momento em que a disciplina se encontra, relativamente, estabilizada na licenciatura e a Libras começa a perpassar por outros ambientes fora das salas de aulas, voltada para outros membros da comunidade acadêmica, como é o caso dos professores e funcionários.

Com relação às observações feitas pelas docentes Carla, Daniela e Emília, todas atuantes em IES públicas, verifica-se questões que se relacionam ao processo de inclusão da disciplina Libras nesse tipo de instituição.

A docente Daniela chamou a atenção sobre a dificuldade que a IES teve para ocupar o cargo de docente de Libras, pois essa instituição realizou quatro concursos públicos para a vaga e em nenhum deles conseguiu preencher a mesma, principalmente, pelas exigências que o concurso demandava da formação docente. 
Como mencionei, na seção anterior, as IES não têm levado em consideração, necessariamente, as normas que constam no Decreto $n^{\circ} 5.626 / 05$ para contratação de seus docentes. De acordo com esse documento, à priori, não há a exigência de professores doutores para assumirem a docência da disciplina Libras, fato que pode ser comprovado pelos perfis dos docentes desta pesquisa, pois apenas uma concluiu o doutorado e duas estavam cursando.

Mas diante das normatividades internas e da autonomia presentes nas IES públicas, o cargo, no caso da docente Daniela, só foi ocupado após a promoção do quinto concurso público. Tal fato pode protelar o processo de inclusão da disciplina na grade curricular em outros cursos da mesma instituição ou de outras instituições, além de tolher o acesso de surdos como docentes pesquisadores em IES públicas, pois poucos são os surdos que concluíram o doutorado e atendem as exigências dos regimentos desse tipo de instituição.

O processo de burocratização presente nas IES públicas foi evidenciado também no relato da docente Carla ao mencionar as dificuldades oriundas da resistência apresentada pelos docentes para sua contratação, consoante ao trecho abaixo:

"Embora a presença do professor de Libras seja uma exigência legal, além do desconhecimento dessa exigência, teve uma resistência com a argumentação de que os departamentos não dispunham de vagas para tal profissional, intensificando-se a discussão: em qual departamento o segundo profissional de Libras (esse ministraria aulas nas licenciaturas em geral) se vincularia no Campus [citou um dos campi da IES pesquisada]?”

Nas últimas três ou quatro décadas, o Ensino Superior no Brasil sofreu algumas transformações que podem ser resumidas por meio da citação da pesquisadora Paula (2000, p. 190):

A partir da década de 70 , as universidades brasileiras tornaram-se instituições complexas, na medida em que ampliaram consideravelmente o número de funções e cargos administrativos, assim como o número de instâncias e órgãos decisórios. Para atender às demandas sociais de expansão do ensino superior, surgiram equipes especializadas em administração e uma nova forma de racionalidade tomou conta da universidade: a burocrático-planificadora. $\mathrm{O}$ controle dos processos, a administração dos recursos e a busca de uma "racionalização" crescente para as instituições universitárias foram responsáveis pelo surgimento de uma racionalidade técnica na qual os fins se ajustam aos meios.

O relato da docente Carla pode exemplificar uma das consequências da "racionalização" presente nas IES e corporificadas pelas atitudes dos docentes. No caso em questão, há o desconhecimento do discurso pautado na diferença linguística e cultural e das normas vinculadas ao mesmo e a resistência prevalece sob as bases do que foi estabelecido discursivamente sobre as normatividades para o ingresso de docentes na IES. 
Tal fato deixa transparecer que a tensão nas relações de poder e saber que envolve a inclusão da disciplina Libras no Ensino Superior encontra-se em voga, de acordo com o enunciado da docente, em cursos como História, Filosofia e Ciências Sociais. Apesar de esses cursos serem reconhecidos pelo cunho reflexivo e crítico pautado em autores que tratam de questões que problematizam as histórias, as culturas, as identidades, as políticas, enfim, os aspectos que perpassam a constituição dos seres humanos e da vida em sociedade. E que muitos desses mesmos autores, também servem de embasamento para os estudos acadêmicos voltados para área da surdez, em especial, os Estudos Surdos em educação.

Para complementar a discussão, o relato da docente Emília aborda a falta de interesse por parte dos coordenadores pela disciplina, como ela mesma diz: "[...] até o momento, nenhum dos coordenadores dos cursos para os quais a disciplina é dirigida me procurou, não tomei esta iniciativa por não ter claro a quem me dirigir. Percebo que existe uma preocupação da existência ou não das aulas, mas não da qualidade delas, da parte destes coordenadores".

Esses acontecimentos ocorreram em IES públicas cujas docentes atuam há no máximo dois anos, ou seja, os relatos exemplificam percepções recentes sobre o processo de inclusão da disciplina que, nesses dois últimos casos, conota mais para a inserção da mesma na grade curricular. As atitudes do corpo docente e dos coordenadores, de acordo com os processos relatados, podem ser relacionadas com a produção de "burocratas profissionais" no interior das IES no sentido explorado por Paula (2000, p. 192):

[...] além da instituição realizar um mecanismo de controle burocrático muito grande sobre o trabalho intelectual, ela acaba também por produzir um conformismo e uma identificação de certos professores em relação às práticas burocráticas, ou seja, ela também produz burocrata profissional, totalmente identificado com a estrutura burocrática.

Mas a resistência frente à língua de modalidade visual-motora de uma comunidade minoritária no Ensino Superior não é uma exclusividade brasileira, nas IES americanas também houve dificuldade na aceitação da ASL. Segundo Wilcox e Wilcox (2005, p. 90):

\footnotetext{
É possível, por exemplo, que a faculdade de artes e ciências em uma grande universidade tenha uma política formal de aceitação da ASL para atender aos requerimentos de língua estrangeira, enquanto as faculdades de engenharia ou educação nessa mesma universidade não possuam tal política ou mesmo não tenham alcançado uma decisão sobre aceitação da ASL para preenchimento desses requerimentos.
}

As dificuldades ou indiferenças frente à institucionalização da disciplina Libras pode ser um processo temporário e adaptativo, que não pode ser generalizado em todas as 
realidades institucionais. Além disso, não se pode deixar de reconhecer o fato de que algumas instituições, fora do universo pesquisado, têm priorizado a contratação de docentes surdos e relativizado a formação necessária para a ocupação do cargo.

Voltando para as IES pesquisadas, alguns docentes também relataram que a Libras começou a despertar o interesse e a vontade de aprendizado da comunidade acadêmica de forma geral. E dependendo da forma com que o docente abordar a mesma em sua prática pedagógica, o contato e a compreensão sobre as diferenças inerentes à comunidade surda brasileira pode se tornar mais factível.

Nesse sentido, em continuidade a discussão dos dados, na próxima seção focarei nos enunciados que compreendem os objetivos, os conteúdos, estratégias metodológicas e alguns exercícios que perfazem, de forma mais geral, a prática pedagógica empreendida pelos docentes na disciplina.

\subsection{Práticas pedagógicas}

Nessa seção, primeiramente, concentrarei esforços na discussão dos objetivos estabelecidos para a disciplina Libras, de acordo com os planos de ensino e com os enunciados dos docentes, complementados pela exposição das facilidades e/ou dificuldades encontradas para alcançar tais objetivos nas práticas pedagógicas adotadas.

Em seguida, ao enfatizar os enunciados e alguns dados dos planos de ensino, tratarei dos assuntos que perfazem os conteúdos priorizados pelos docentes, as modalidades comunicativas utilizadas, as estratégias metodológicas e alguns exercícios que compõem a disciplina Libras.

Por meio dos objetivos elencados nos planos de ensino da disciplina Libras nas IES verifica-se, primeiramente, que a disciplina não se compromete apenas com o ensino da língua em si, como sugere a nomenclatura adotada pela maioria delas: "Libras", "Língua Brasileira de Sinais", "Introdução à Língua Brasileira de Sinais". Estas e as nomeadas como "Educação bilíngue: Libras/Língua Portuguesa" e "Educação, Inclusão e Libras", demonstram vínculo com saberes construídos que ultrapassam as questões que envolvem a aquisição da língua de sinais e compreendem a história da educação de surdos, as políticas educacionais bilíngues e inclusivas, a diferenças entre as línguas de sinais e a língua portuguesa, o papel do professor na educação de surdos, a comunidade, identidade e cultura surdas. 
Os objetivos estabelecidos para a disciplina além de revelar o caráter holístico, com predominância para os temas teóricos, tendem a ser localizados no discurso da diferença linguística e cultural. Pois, nos planos de ensino, no que se refere aos objetivos, não há a alusão, propriamente dita, dos aspectos clínicos/patológicos da surdez.

Como abordei na fundamentação teórica, a Libras como objeto de ensino em ambientes institucionais no Brasil é relativamente recente, mesmo quando se considera igrejas e associações, e quando se pensa em instituições educacionais sua formalização, enquanto disciplina, tem ocorrido nessa última década. Porém, em países em que a língua de sinais tem uma tradição institucional anterior à brasileira como, por exemplo, os EUA, o ensino da língua de sinais nem sempre esteve atrelado à diferença linguística e cultural. Nesse sentido, atestam Wilcox e Wilcox $(2005$, p.123) “[...] as aulas de línguas sinalizadas eram ministradas de um ponto de vista clínico/patológico e o legado cultural da comunidade Surda, bem como a rica estrutura linguística da ASL foram sempre ignoradas".

Tal fato ocorria, segundo os autores, na década de 1970, 80 e 90, o que permite compreender as mudanças dos enunciados no tempo, ou seja, a consolidação de um determinado discurso não significa o engessamento do mesmo, outras construções discursivas continuam ocorrendo como "fragmento de história, unidade e descontinuidade na própria história" (FOUCAULT, 2013b, p.143).

Os docentes, em seus enunciados, valorizam a necessidade de mudança na perspectiva discursiva de seus alunos, e buscam por meio da disciplina a propagação de saberes que eles consideram como verdadeiros no que tange à língua sinais e o surdo.

"Meu maior objetivo é que os alunos rompam preconceitos [...]” Ana.

“[...] Ensino também a gramática da Libras, para que os alunos tenham a ciência de que se trata de uma língua de fato, porque muitos chegam achando que o que fazemos é o português sinalizado[...]” Bruno.

“[...] Que eles entendam quem é o aluno surdo [...]” Daniela.

“[...] Que os alunos tenham contato com a língua de sinais, primeiramente sabendo da existência dela, e possam saber da importância dessa língua para os surdos [...]” Emília.

“[...] desmistificar a questão da surdez ligada a 'mudez'. Em segundo lugar é promover o conhecimento da comunidade surda como sendo uma comunidade que tem possibilidades de aprendizagem [...]" Flávia. 
Por meio dos termos utilizados, os docentes assumem que a disciplina, além de ensinar a língua de sinais, tem como funções: romper preconceitos, desmistificar, promover a ciência e o conhecimento ora sobre a língua ora sobre os surdos.

Os enunciados demonstram que os saberes considerados como "não verdadeiros", apresentam correspondência com o discurso que prioriza a normalidade sociocomunicativa pautada ouvinte, e que discuti ao longo desta dissertação. Pois os docentes afirmam que é preciso abordar na disciplina que a surdez é diferente da mudez, que a língua de sinais é uma língua e que a comunidade surda pode aprender.

A pesquisa de Almeida (2012) contemplou o ponto de vista de alunos da disciplina Libras em uma IES pública e aponta que:

\begin{abstract}
Dos alunos que responderam ao formulário, $70 \%$ caracterizam a surdez dentro de uma perspectiva clínica, enfocando a condição fisiológica da surdez, $15 \%$ não se manifestaram sobre essa questão. Apenas 5\% fizeram considerações acerca da surdez que se aproxima de uma concepção mais cultural. Outros 5\% dos alunos admitiram não conseguir caracterizar a surdez. (ALMEIDA, 2012, p.54).
\end{abstract}

Pressupõe-se que a disciplina tem como responsabilidade desconstruir os saberes previamente correntes entre os discentes, por saberes que remetem a um discurso distinto. Tal fato permite a localização dos objetivos estabelecidos na disciplina nas relações de poder e saber pertinentes ao surdo e à língua de sinais.

Outro fato observado nos objetivos dos planos de ensino é que os mesmos abarcam tanto os temas teóricos quanto os práticos, dos quais retomarei na apresentação dos dados sobre os conteúdos. O que destacarei agora, é que nos enunciados proferidos pelos docentes encontra-se uma regularidade que contempla a aquisição prática da língua de sinais e a compreensão sobre a gramática da mesma, inicialmente, na disciplina, com perspectivas de aprofundamento futuro, em outro local. Como apresento nos trechos abaixo:

“[...] que os alunos [...] tenham um primeiro contato positivo com a língua, abrindo caminho para um possível aprofundamento futuro” Ana.

"[...] eu me preocupo em ensinar sinais básicos, como cumprimentos, alimentação, verbos. Ensino também a gramática da Libras [...] e deixo muito claro para os alunos que se quiserem conhecer um pouco mais, deverão aprofundar-se em cursos que ensinam Libras como língua[...]. O que consigo fazer é ensinar "Libras instrumental”, para um primeiro contato com o surdo [...]” Bruno.

“Comunicar-se com sinais básicos da Libras em situações diversas; Desenvolver uma noção geral da composição linguística das línguas de sinais; Construir aproximações quanto às questões metodológicas do ensino e aprendizagem em Libras " Carla. 
"[...] Meu objetivo maior com essa disciplina é fazer com que os alunos tenham contato com a língua. E que tenham um aprendizado que eu chamo de básico. A gente adotou um dicionário de apoio e a intenção é que, primeiro, eles conheçam a língua, conheçam as características gramaticais [...], além de todo esse referencial teórico paralelo sobre surdez. Que conheçam a estrutura gramatical da língua de sinais e passem a utilizar a língua de sinais na sala de aula” Daniela.

"O objetivo mais geral é que os alunos tenham contato com a língua de sinais, [...]. Promovendo ou incentivando que eles tenham contato com a comunidade surda, não somente para conhecer a língua, mas para compreender o seu funcionamento $e$ importância para esse grupo” Emília.

"Tento aprofundar o conhecimento dos sinais por meio de histórias e de apresentações dos alunos com pequenos diálogos” Flávia.

Os docentes, em sua maioria, consideram que é objetivo da disciplina promover o contato com a língua de sinais e a aquisição dos sinais correspondentes ao domínio básico, bem como o conhecimentos sobre o status linguístico da Libras e a sua gramática.

No que se refere ao domínio básico da língua de sinais, Leite (2004) traz o relato de uma professora surda da Feneis de São Paulo que indicia o que tem se configurado no ensino da Libras em cursos livres de diferentes níveis:

\footnotetext{
Tem um nível básico, que ainda é bem restrito, só trata das coisas principais que a gente usa na vida. No nível intermediário, já aumenta um pouco, a pessoa tem que utilizar mais o corpo, as expressões faciais, os classificadores. No nível avançado, a pessoa tem que ler textos [...] e precisa imaginar como sinalizar aquilo, como iria interpretar para os surdos [...]. (LEITE, 2004, p. 212).
}

Estabelecendo uma analogia dos enunciados docentes com o relato da professora da Feneis entendo que a disciplina pode-se configurar com o desenvolvimento da comunicação inicial cotidiana. Não obstante, retomarei essa questão na subseção que trata dos conteúdos.

Para finalizar a discussão que concerne aos objetivos estabelecidos, apesar da ampla gama de temas inerentes aos mesmos, a maioria dos docentes considera que os objetivos têm sido alcançados, entretanto, alertam para alguns elementos dificultadores. Dentre estes, constam a carga horária destinada para a disciplina e a quantidade de alunos por turmas, fatores que também apareceram nas pesquisas de Pereira (2008), Rebouças (2009), Caetano (2011) e Almeida (2012).

Wilcox e Wilcox (2005, p. 124) recomendam que: 
Os elaboradores de programas de ensino devem estar cientes do tempo disponível para o desenvolvimento do curso. Oferecer instrução mínima em uma segunda língua significa oferecer vários semestre de aulas dessa língua. Pelo menos um curso separado sobre cultura surda deve ser incluído.

Porém, essa não é uma alternativa observada, por enquanto, na realidade brasileira. Principalmente, porque a disciplina encontra-se em processo de inclusão nas grades curriculares dos cursos de licenciatura atendendo uma normatividade legal e sofrendo resistências durante a institucionalização, conforme discuti em outro momento. E, a priori, as possibilidades citadas pelos docentes centram-se na recomendação dos discentes buscarem outros cursos de língua de sinais para complementarem suas formações.

O que se percebe são algumas iniciativas de IES que tem ofertado cursos de licenciatura, no caso, Pedagogia com foco na educação bilíngue para surdos e Letras- Libras, cujas grades curriculares contemplam várias disciplinas com foco na língua de sinais, na educação de surdos e na cultura surda. Mas, esses são cursos mais específicos, e isso não significa que outros cursos voltados para a educação geral ampliem a carga horária da disciplina existente ou insiram outras disciplinas correlatas nas grades curriculares.

Essa contingência dependerá do espaço que a disciplina Libras poderá galgar nas relações de poder e saber estabelecidas nas IES e na organização dos currículos dos cursos de licenciatura, ou até mesmo de outros cursos. E, nesse processo, não apenas o papel do docente de Libras se torna relevante, mas o papel dos discentes da disciplina também o é. Pois, por meio dos dados coletados, os discentes são citados como contribuidores para o alcance dos objetivos propostos.

Nesse sentido, atestam o docente Bruno "os alunos gostam muito da disciplina e contam experiências que viveram quando encontram algum surdo", a docente Daniela "como facilidades, destaco a motivação dos alunos por compreenderem questões relacionadas a Libras", e a docente Emília "os alunos foram extremamente receptivos e envolvidos".

Com a exposição e análise dos objetivos elencados verificaram-se algumas das principais demandas atribuídas à disciplina Libras e à qual discurso o conjunto de enunciados, presente nos planos de ensino e nas respostas docentes, tende a se filiar.

Para complementar os enunciados até então abordados, contemplarei os conteúdos considerados como prioritários para a disciplina Libras e outros dados que podem delinear, de forma geral, como tem sido as práticas desenvolvidas pelos docentes como, por exemplo, as informações que concernem às modalidades linguísticas adotadas, às estratégias 
metodológicas e às atividades/exercícios propostos, conforme emergiam dos enunciados dos docentes e dos planos de ensino.

A prática pedagógica desenvolvida nas aulas de Libras nas IES pode ser considerada como um dos elementos primordiais para a difusão discursiva sobre os surdos e a língua de sinais e para consolidação de normas que servem - ou servirão - de base para a disciplina e seu caráter diferenciador e/ou afirmativo na construção de saberes frente às demais disciplinas dos currículos dos cursos de licenciatura.

Santomé (2013, p.156) coloca que a pretensão da ação educativa é: Desenvolver capacidade para tomada de decisões, propiciar aos alunos e às alunas e
ao próprio professorado uma reconstrução reflexiva e crítica da realidade, tomando
como ponto de partida as teorias, conceitos, procedimentos e costumes que existem
nessa comunidade e aos quais se deve facilitar o acesso. Nesse trabalho de formação
de pessoas críticas, ativas e solidárias, e de ajuda na reconstrução da realidade, é
imprescindível prestar atenção prioritária aos conteúdos culturais, assim como,
naturalmente, às estratégias de ensino e aprendizagem e avaliação para levar a cabo
tal missão.

$\mathrm{Na}$ discussão que se segue, seja por meio dos enunciados dos professores ou por meio das descrições contidas no plano de ensino, ou até mesmo da combinação de ambos, abordarei, na medida do possível, a reconstrução reflexiva e crítica da realidade que permeia o ensino da língua de sinais e que são indiciadas nos conteúdos fundamentais apontados pelos docentes na disciplina Libras, nas estratégias desenvolvidas nas aulas e em alguns exercícios, com ou sem teor avaliativo.

Considero válido destacar, primeiramente, que diante da congruência entre os conteúdos e os objetivos elencados no plano de ensino, iniciarei destacando nos enunciados dos docentes o que eles consideram como conteúdos prioritários para o desenvolvimento das aulas da disciplina Libras nas diferentes IES em complementação aos temas que apareceram nos objetivos em si.

Os docentes em seus relatos manifestam o interesse em contemplar conteúdos que agreguem "novos" paradigmas sobre os saberes construídos sobre os surdos e a língua de sinais pelos discentes. Para tanto, há todo um empreendimento teórico para contextualizar historicamente e, até mesmo, justificar a presença da disciplina Libras nos cursos em que eles ministram as aulas, como se nota nos destaques que realizei nos enunciados abaixo:

"Primeiramente, tratar a respeito da recente formalização da língua, o que implica em uma profusão de sinais divergentes e, por vezes não registrados em dicionários. É preciso abordar a questão para que o aluno ouvinte não se sinta inseguro em relação ao aprendizado [...]. E por fim a cultura surda como objeto de estudo para a educação” Ana. 
"Em primeiro lugar, falar de quem é o surdo, uma pessoa que possui uma identidade distinta da dos ouvintes e explicar o que é língua de sinais. Muitos alunos chegam com o conceito do 'surdo-mudo', que a língua de sinais não é língua (linguagem dos sinais) e que basta você colocar os sinais na estrutura da língua portuguesa. O primeiro passo é desmistificar este processo" Bruno.

"Para uma aproximação dos estudantes de graduação com o foco da disciplina Libras e Língua Portuguesa na educação de surdos, são priorizados os seguintes conteúdos: Histórico da educação dos surdos e das abordagens de comunicação; Mitos e verdades das línguas de sinais; Inclusão educacional em perspectiva bilíngue; Identidade, cultura e comunidade Surda; A Libras em suas singularidades linguísticas e seus efeitos sobre o desenvolvimento, aquisição da Língua Portuguesa e produções culturais [...] " Carla.

“[...] a estrutura gramatical da língua de sinais, a educação inclusiva, o perfil do aluno surdo, abordagens educacionais históricas da surdez, história da língua de sinais, a educação dos surdos no Brasil, políticas públicas [...], além do trabalho relacionado à prática e ao estudo da língua, itens linguísticos que compõem a língua”. [...] A terminologia surdo-mudo, linguagem de sinais [...], explicar outros mitos relacionados a questões características da surdez, implante coclear [...] a gente acaba abordando um pouco, porque eles têm curiosidade, 'o que é implante coclear?'. 'Uma perda profunda é igual a uma perda moderada?'. Eles não tinham essa noção, para eles todo surdo é igual, [...] tudo isso é preciso trabalhar, os tipos de perda, os graus de perda, que são panos de fundo [...]" Daniela.

"O conhecimento do histórico da educação de surdos é importante para que os alunos saibam, para que e porque existe esta disciplina no seu currículo, este conhecimento determina o envolvimento do aluno na disciplina e amplia a discussão a respeito da língua [...]” Emília.

“[...] não podemos deixar de abordar na disciplina a história dos surdos e das suas conquistas, creio que aula de Libras não é somente 'fazer sinais', mas é compreender o porquê fazemos e de que forma isto beneficia uma comunidade diferente da minha” Flávia.

No que concerne aos conteúdos teóricos destacados há a valorização sobre a compreensão da história da educação de surdos, do status atribuído à língua de sinais, da educação inclusiva, das características do surdo com apontamentos para as questões de identidade, comunidade e cultura, e, em um dos relatos, também há a menção as questões 
clínicas como o grau de surdez e o implante coclear, mas ainda sim, dentro de um contexto que procura evidenciar a diferença.

Da mesma maneira que nos objetivos, nos conteúdos os docentes reiteram a falta de conhecimento sobre os saberes que são difundidos na disciplina e chamam a atenção para a base de saberes calcados na normalidade sociocomunicativa pautada no ouvinte e proferidos pelos discentes no início das aulas.

Outro fato a ser mencionado é o conteúdo sobre a história da educação de surdos ter aparecido claramente nos enunciados de quatro docentes e nos dois docentes que não mencionaram, o mesmo consta em seus planos de ensino. Tal fato indica o peso discursivo que pode ser atribuído à construção histórica que permeia o surdo, afirmando-se como um saber canônico que circula nas construções discursivas presentes nas relações de poder e saber em torno da área da surdez e da língua de sinais, conforme abordei na fundamentação teórica desta pesquisa.

Os "mitos" e a necessidade de "desmistificar" terminologias ou temas que perpassam pela disciplina, constituem-se como termos que se filiam a forma com que alguns saberes que foram proferidos e incorporados em um dado momento na história, foram sendo substituídos por outros que, paulatinamente, tem se propagado como verdade ao serem abordados e reiterados, especialmente, no meio acadêmico.

Dentre as concepções hoje consideradas inadequadas, os docentes destacam as terminologias "surdo-mudo" e "linguagem de sinais", e a concepção de que "a língua de sinais não é língua" e que trata-se de um "português sinalizado". Tais concepções costumam circular de forma frequente na sociedade, de forma geral, conforme discuti no capítulo " $A$ cultura surda no contexto dos Estudos Culturais" desta pesquisa, e ainda são correntes entre os discentes que frequentam a disciplina Libras, conforme indicam os enunciados, em cursos livres de Libras e/ou em cursos de outras línguas de sinais, em países como os EUA (WILCOX e WILCOX, 2005).

Para exemplificar, cito o relato de uma aluna que consta na pesquisa de Gesser (2012, p.69):

Eu sempre tive curiosidade em aprender os gestos que os surdos fazem. Quando fiquei sabendo do curso aqui, fui correndo para fazer inscrição. No início fiquei com medo porque acho que não tenho muita facilidade para aprender línguas, Na época que eu busquei este curso, eu nem sabia que a Libras era língua. Eu sempre pensei que fosse aquela coisa de fazer o alfabeto manual sabe? Igual uma língua portuguesa falada no ar... Depois entendi que são duas línguas diferentes, mas mesmo assim me pergunto se não seria mais fácil para todos se a Libras fosse uma versão sinalizada do Português, afinal estamos no Brasil, né? 
Na pesquisa de Gesser (2012) há outros relatos de alunos de cursos de Libras que vão ao encontro do que os docentes relataram na minha pesquisa sobre a necessidade da abordagem de conteúdos com perspectivas mais atuais e fundamentadas sobre as terminologias e concepções empregadas sobre a língua de sinais e os surdos, no processo de ensino-aprendizagem da disciplina.

Ainda no que concerne aos conteúdos teóricos e tomando como premissa o discurso pautado na diferença linguística e cultural, destaco a alusão da "cultural surda como objeto de estudo da educação", da "identidade, cultura e comunidade Surda", do surdo como "uma pessoa que possui uma identidade distinta da dos ouvintes", da "Libras em suas singularidades linguísticas e seus efeitos sobre o desenvolvimento, aquisição da Língua Portuguesa e produções culturais”e que a "Libras não é somente 'fazer sinais', mas é compreender o porquê fazemos e de que forma isto beneficia uma comunidade diferente”.

Tais trechos evidenciam que nos conteúdos elencados os docentes também contemplam discussões que perfazem a identidade, a comunidade e a cultura surda, fato relevante quando se pensa que a língua de sinais não está apenas a serviço do acesso e permanência do aluno surdo no ambiente escolar. Em consonância com o que discuti ao longo da fundamentação teórica, a essa língua é atribuída a contribuição para que seus usuários fortaleçam as relações sociais e políticas, mobilizem resistências, construam identidades e produzam e compartilhem cultura.

$\mathrm{Na}$ subseção seguinte retomarei a questão da construção discursiva sobre a cultura surda na prática pedagógica da disciplina Libras.

Para finalizar a discussão sobre os conteúdos teóricos, destaco alguns exercícios aplicados na disciplina e que são descritos no sentido de praticar e/ou de avaliar esses conteúdos.

Nos dados contidos nos planos de ensino dos docentes, há a proposição de exercícios que são adotados pela maioria das disciplinas acadêmicas, dentre eles: seminários, resenhas, relatórios, sínteses, análises de filmes e provas objetiva e discursiva. A única atividade que se relaciona a especificidade do que foi abordado nas aulas teóricas é a proposta contida no plano de ensino do docente Bruno, no qual "os alunos precisam imaginar como seriam as iniciativas para a inclusão no bairro em que residem”, lembrando que nessa disciplina, além da Libras, há o direcionamento de tópicos sobre a educação inclusiva, não apenas para surdos, mas também para outros públicos.

De acordo com Foucault (2013c, p. 155) o exercício pode ser compreendido como: 
[...] A técnica pela qual se impõe aos corpos tarefas ao mesmo tempo repetitivas e diferentes, mas sempre graduadas. Dirigindo o comportamento para um estado terminal, o exercício permite uma perpétua caracterização do indivíduo seja em relação a esse termo, seja em relação aos outros indivíduos, seja em relação a um tipo de percurso. Assim, realiza, na forma da continuidade e da coerção, um crescimento, uma observação, uma qualificação.

Nesse sentido, verifica-se que a disciplina Libras, no que se refere aos conteúdos teóricos, tem incorporado exercícios que tradicionalmente circulam em ambientes educacionais, e que quando se configuram como exames permitem que a individualidade adentre no campo documentário. "Um 'poder de escrita' é constituído como uma peça essencial nas engrenagens da disciplina" (FOUCAULT, 2013c, p. 181).

E, ainda nessa subseção retomarei a discussão sobre os exercícios propostos na disciplina Libras, mas com foco nos conteúdos práticos dos quais começarei a explanação do que os docentes disseram, logo abaixo.

"Primeiramente, tratar a respeito da recente formalização da língua, o que implica em uma profusão de sinais divergentes e, por vezes não registrados em dicionários. É preciso abordar a questão para que o aluno ouvinte não se sinta inseguro em relação ao aprendizado [...]. Também é necessário abordar sobre aspectos práticos tais como os aspectos que constituem os sinais (configuração de mão, movimento, etc) [...]” Ana.

"[...] apresentar o alfabeto manual e as configurações de mão. Então começamos com os cumprimentos, para que os alunos aprendam como fazer um 'Oi' para o surdo. Em seguida ensino [...] o endereço, os sinais de cidade, bairro, etc. Então começamos a abordar os vocábulos de família, Estados, alimentos, alguns verbos. Procuro também ensinar a gramática, como os tipos de verbos, tipos de frase, os negativos em Libras, e o mais importante: as diferenças entre língua de sinais e língua portuguesa” Bruno.

“[...] Introdução ao conhecimento prático da Libras: léxico e noções gramaticais;[...] Proposição de situações teórico-práticas que possibilitem uma vivência com a língua de sinais e com a cultura e identidade surda [...]" Carla.

“[...] Em termos de léxico [...] verbos, substantivos, adjetivos, advérbios [...] uma quantidade mínima [...] para que esse aluno possa se comunicar e até entender o funcionamento da língua. [...] [Mas] é tudo contextualizado [...], eu vou 'falando' e eles vão traduzindo, conto pequenos episódios para tradução [...], priorizo a conversação para não ficar o léxico puro” Daniela.

“[...] Tento aprofundar o conhecimento dos sinais por meio de histórias e de apresentações dos alunos com pequenos diálogos” Flávia. 
Diante do que foi exposto, destaco três elementos principais dos relatos dos docentes no que concerne as aulas com teor mais prático de ensino da Libras: o primeiro é a priorização do ensino do léxico por meio de categorias semânticas; o segundo é a gramática da Libras e sua diferença com relação à gramática da Língua Portuguesa (esse foi um tema recorrente em vários enunciados e pode ser tratado tanto de forma teórica quanto prática); e o terceiro é a proposição de situações de compreensão e expressão da língua.

Até pouco tempo atrás, era predominante no ensino da Libras em cursos livres no Brasil, pelo menos nos módulos iniciais, a apresentação de uma lista de sinais por categorias semânticas pelo professor e a reprodução pelos alunos sem que houvesse a exploração comunicativa e muito menos a apresentação "formal" dos elementos gramaticais da língua, conforme exemplifiquei na introdução desta pesquisa. Porém, essa prática, ponderam Leite e McCleary, pode gerar equívocos por parte dos alunos, na medida em que:

\begin{abstract}
A falta de uma escrita para a Libras faz com que os sinais sejam frequentemente designados por glosas (i.e. palavras do Português convencionalmente adotadas para se referir aos sinais). [...] seria útil chamar a atenção dos alunos para o fato de essas glosas serem apenas nomes arbitrários convencionados para se referir ao sinal, a fim de não serem confundidas com a semântica própria do sinal na Libras. (LEITE; McCLEARY, 2009, p. 267).
\end{abstract}

Gradualmente observa-se que os professores de Libras têm inserido nas aulas situações interativas ou tem priorizado a comunicação e, consoante com os diferentes contextos propostos, trabalha-se, pontualmente, com o léxico e os elementos gramaticais.

Com o significativo aumento dos ambientes institucionais que ofertam o ensino da Libras ampliam-se o movimento entre os professores para aprimorarem sua prática, no sentido de promover uma aprendizagem de língua mais significativa para os alunos ouvintes.

Essa preocupação tem uma tradição maior no ensino de línguas estrangeiras na modalidade oral-auditiva e relaciona-se com a ampliação de pesquisas acadêmicas sobre as abordagens metodológicas, o lançamento de recursos materiais (como livros para o aluno e guias pedagógicos para professores, CDs e DVDs) e na abertura de várias escolas de idiomas.

Em menor proporção, em decorrência do descrédito histórico e da profusão relativamente recente de estudos linguísticos sobre as línguas de sinais, se tem empreendido pesquisas acadêmicas e a elaboração de materiais sobre o ensino das línguas de modalidade visual-motora.

De acordo com Wilcox e Wilcox (2005) no ensino da ASL houve a proposição de algumas abordagens que podem ser resumidas da seguinte forma: primeiramente, priorizavase a apresentação de sinais e o treino de algumas sentenças devidamente organizadas; depois, 
houve a proposta de um aprendizado consciente da estrutura gramatical; em seguida, estabeleceu-se um ensino cujo conteúdo era apresentado em forma de espiral, do mais básico ao mais complexo, e com a memorização de diálogos; e finalmente, os autores apresentam as abordagens funcionais, que concebem o ensino da língua dentro de contextos relacionados à comunicação da vida diária.

No entanto, no ensino da Libras, há uma certa carência de estudos e materiais que tragam alguns apontamentos sobre as abordagens que fundamentam a prática pedagógica dos instrutores/docentes dessas línguas.

Pensando nos docentes desta pesquisa, como eles são ouvintes, em suas estratégias afirmam utilizar a Libras, principalmente em situações práticas, e lançam mão do uso da Língua Portuguesa oral e/ou escrita, quando precisam explicar algo sobre a Libras ou nas aulas de cunho mais teórico. Percebe-se que alguns docentes se preocupam com a compreensão, por parte dos alunos, do que é dito em Libras, e por isso, mudam a modalidade linguística quando notam que esses alunos já demonstram maior familiaridade com a língua visual-motora. Em conformidade com os destaques realizados nos trechos abaixo:

“É preciso abordar a questão [da divergência de sinais e do não registro dos mesmos em dicionários] para que o aluno ouvinte não se sinta inseguro em relação ao aprendizado [...] Em maior parte, a aula é exposta oralmente. Nos exercícios, ao passo que os alunos ganham vocabulário, vou inserindo os sinais e frases completas” Ana.

"No início falo em português. Em algumas aulas eu ministro apenas em Libras. Este semestre, por exemplo, no curso de Educação Física eu ministro as aulas apenas em Libras. Quando os alunos não entendem, vou à lousa e escrevo a palavra que estava sinalizando. Esta experiência tem sido muito positiva e tem dado certo [...]” Bruno.

"Libras, Língua Portuguesa oral e Língua Portuguesa escrita [...] a gente faz toda uma crítica em relação à interpretação, [sobre] o português sinalizado, a interpretação da música para o surdo, então [...] as estratégias vão sendo intercaladas” Daniela.

“[...] nas aulas práticas existe uma mescla de momentos: em alguns a língua de sinais é apresentada sem a língua oral em outros essa é explicada através da língua oral”, Emília.

"Utilizo muito a língua de sinais (sem tradução simultânea), em momentos de aula teórica utilizo a oralidade e tento fazer o bimodalismo quando o professor surdo está junto" Flávia.

O uso da Língua Portuguesa em aulas de Libras tem sido banido da prática de alguns professores surdos, especialmente, aqueles que foram modificando suas metodologias de 
ensino conforme as trocas estabelecidas com outros colegas de profissão mais experientes ou com professores surdos de outros países. Nesse sentido, destaco um relato que consta na pesquisa de Leite (2004, p. 210):

No começo, quando o Ricardo ([um dos primeiros professores de LSB]) estava
aprendendo a dar aulas, ele usava palavras também, em português. Depois veio um
amigo dele dos Estados Unidos, um instrutor, e falou para ele que português não era
bom, que ensinar através de palavras não era bom. O Ricardo ainda não sabia disso.
Depois veio também um amigo da Holanda e falou a mesma coisa: "Português não é
bom. É melhor você ir para a Europa ver como é lá". O Ricardo começou a guardar
dinheiro e quando terminou de juntar, viajou de avião para lá. "como é que não se
usa nada de português?" Ele pensou, mas acabou aprendendo como eles ensinavam.
Quando voltou para o Brasil, mudou de método e passou a não usar mais português,
e até hoje é assim. Então ele falou para mim e eu mudei também, porque ele estava
certo.

Por meio desse relato fica claro o processo de estabelecimento e propagação de um discurso entre os surdos de diferentes países e isso favorece a consolidação de normas que começam a ser adotadas no ensino de várias línguas de sinais.

A perspectiva inicial de usar a Língua Portuguesa nas aulas de Libras por professores surdos é relacionada por Leite (2004) e Gesser (2012) ao papel que a Língua Portuguesa teve na educação desses professores quando alunos, numa época em que a língua de sinais não era uma prioridade no ensino dos mesmos. Logo, na posição de professor pode haver certa dificuldade em se desvencilhar daquela língua que foi supervalorizada no contexto escolar e ainda é - no contexto social majoritário.

De forma complementar, pensando nos docentes desta pesquisa e das modalidades linguísticas por eles utilizadas na prática pedagógica, faço uma analogia ao fato deles serem ouvintes e terem a Língua Portuguesa como língua materna e a Libras como L2, exceto o docente Bruno que por ser filho de pais surdos estabeleceu uma relação linguística materna também baseada em "sinais caseiros".

Como abordei anteriormente, o processo de ensino-aprendizagem de línguas de sinais como L2, até bem pouco tempo atrás, estava centrado na apresentação do sinal e na palavra “correspondente" em Língua Portuguesa, nesse contexto, podem ser inseridas as possíveis experiências que a maioria dos docentes da disciplina, enquanto alunos tiveram, nos cursos de Libras ofertados.

Esse tipo de ensino foi, inclusive, apontado como um dos fatores que podem dificultar o aprendizado da língua de sinais por ouvintes:

O plano morfossintático constituiu-se num dos aspectos de maior dificuldade no aprendizado da Libras. Parecia bastante difundida, entre os professores, a ideia de que primeiro devemos aprender sinais isolados para depois aprender a combiná-los, o que se revelava na estratégia de sempre introduzir uma lista de sinais antes de 
atividades de uso da Libras em interação. Tal visão resultou no desenvolvimento de hábitos prejudiciais por parte dos alunos ouvintes, que se viam sem alternativa a não ser a de empregar os sinais que eles conheciam na estrutura mais linear do Português, que difere significativamente da estrutura mais espacial da Libras. (LEITE; McCLEARY, 2009, p. 251).

Da mesma forma que o professor surdo nas atividades de docência pode se basear em experiências que teve como aluno da L2, no caso a Língua Portuguesa, o docente ouvinte pode passar pela mesma situação quando sua L2 é a Libras. Presume-se que o ensino de línguas, em especial as de modalidades comunicativas distintas, demandam análises mais complexas, das quais não poderei aprofundar nesta pesquisa, mas que ficam como sugestões para pesquisas futuras. Estas podem contemplar não apenas o papel da L2 de modalidade visual-motora, mas também o papel da língua materna ou L1 de modalidade oral-auditiva, e até que ponto esta pode ser "deixada" de lado (se é que isto é possível), no processo de ensino-aprendizagem das línguas de sinais para ouvintes.

Se no ensino bilíngue para surdos a defesa discursiva recai na importância da aquisição da Libras para estruturação da linguagem e, consequente, na maior facilidade para a aprendizagem da Língua Portuguesa como L2, seja na modalidade escrita e/ou na oral, tornase conflitante a defesa da exclusão completa da L1 dos ouvintes quando estes estão aprendendo uma língua de sinais.

Essa discussão pode ser localizada nas tensões estabelecidas nas relações de poder e saber que envolvem a língua de sinais, nas quais se afirmam outras normatividades centradas não apenas nos surdos, mas também nos ouvintes enquanto alunos ou professores dessa língua ou como tradutores-intérpretes da mesma.

Gesser (2012, p.117) defende que:

O uso do português em sua versão escrita deve ser encarado como ferramenta de aprendizagem, ou seja, como mais um recurso a ser utilizado na sala de aula pelo professor surdo [acrescento - ou pelo professor ouvinte]. Embora a língua de sinais conte com alguns sistemas de escrita, eles ainda não fazem parte do conteúdo e do repertório de ensino durante o ensino de Libras para ouvintes. E, possivelmente, mesmo que tal sistema fosse trabalhado, acredito que muito do material didático, das explanações no quadro e das informações projetadas nas transparências seriam escritas em português pelo professor. A escrita da língua materna dos aprendizes ocupa, portanto, um espaço significativo em sala de aula e pode ser utilizada por várias motivações: por uma questão de hábito, para se ter um registro do que foi ensinado, para memorizar o conteúdo ou até mesmo pela própria insegurança dos ouvintes com essa nova modalidade sinalizada da língua.

Wilcox e Wilcox (2005) também enfatizam a presença das línguas orais nos cursos dedicados ao ensino de línguas de sinais, especialmente, quando há a necessidade de esclarecimentos de questões que subjazem aspectos teóricos sobre os surdos, a cultura surda e 
as línguas de sinais, caso análogo à tendência estabelecida discursivamente pelos docentes da disciplina Libras nos cursos de licenciatura nas IES que pesquisei, e fato também apontado na pesquisa de Almeida (2012).

Dessa pesquisa destaco o depoimento de uma professora surda oralizada, que ministra a disciplina Libras no curso de Pedagogia de uma IES pública do Paraná:

Eu uso mais a oralidade para me comunicar. No início falo mais com eles. Depois que eles já sabem um pouco de Libras aproveito para utilizar os sinais que eles já conhecem como cumprimentar, "oi, tudo bem?" E eles tentam entender então começo a introduzir mais a Libras no diálogo com os alunos. (ALMEIDA, 2012, p. $100)$.

Inclusive, a mesma docente menciona que sente a necessidade da presença do Tils a acompanhando em algumas aulas para que os alunos se sintam mais seguros para perguntarem e interagirem.

Retomando os enunciados dos docentes e dos dados levantados nos planos de ensino, o contato e/ou uso da Libras é afirmado não só no desenvolvimento lexical, mas também no emprego de estratégias que contemplam situações dialógicas e o contato com diferentes gêneros discursivos produzidos em língua de sinais como, por exemplo, histórias, fábulas e poesias.

O ensino de línguas tem assumido um caráter mais holístico para atender aos diferentes públicos e contextos, conforme descreve Gesser (2012, p. 22):

\begin{abstract}
A área de instrução de línguas chegou a um ponto de maturidade, reconhecendo que o contexto de ensino-aprendizagem é tão complexo, multifacetado e diverso em seu contexto [perfil de alunos, tempo de contato com o idioma, escopo e propósitos educacionais (aprender língua para ler textos técnicos, aprender língua para viagem, para fazer negócios, para passar no vestibular...)], que hoje não se fala mais em métodos isoladamente, tampouco na necessidade de criar novos métodos. Nenhuma metodologia e/ou método consegue abarcar em sua proposta a composição heterogênea dos contextos e das diferenças individuais dos aprendizes.
\end{abstract}

Obviamente que o recente ensino da Libras, no Ensino Superior, ainda não alcançou tal maturidade, contudo, fazendo alusão aos docentes e seus enunciados, em conformidade com o que expus nos objetivos, há uma tendência para a consolidação do ensino básico da língua de sinais nos cursos de licenciatura na disciplina para a comunicação inicial dos discentes ouvintes com o público surdo.

Para tanto, os docentes têm experimentado diferentes estratégias e recursos, ao mesmo tempo em que promovem o incentivo de situações e contextos comunicativos. Segundo os enunciados do docente Bruno, "começamos com os cumprimentos, para que os alunos aprendam como fazer um 'Oi' para o surdo"; da docente Carla "Proposição de situações 
teórico-práticas que possibilitem uma vivência com a língua de sinais e com a cultura e identidade surda"; da docente Daniela "para que esse aluno possa se comunicar e até entender o funcionamento da língua. [...] [Mas] é tudo contextualizado [...] priorizo a conversação para não ficar o léxico puro"; e da docente Flávia "Tento aprofundar o conhecimento dos sinais por meio de histórias e de apresentações dos alunos com pequenos diálogos [...]. [...] Como trabalho com um surdo procuro suscitar discussões na classe buscando que os alunos visualizem o conhecimento desse professor e que ele possa trazer experiências significativas aos alunos".

De forma complementar, mesmo que se proponha o desenvolvimento da comunicação inicial com os surdos em um ambiente artificial, no caso, as salas de aulas das IES, o ambiente de comunicação natural pode ser acessível diante da presença dos usuários da língua de sinais em todo o território nacional. Pois, na maioria das cidades, os membros das comunidades costumam estabelecer pontos de encontro, relativamente fixos, em diferentes ambientes sociais (shoppings centers, praças, terminais de ônibus, entre outros) e institucionais (escolas para surdos, igrejas e associações). Essa é uma das vantagens que os alunos ouvintes dos cursos de Libras têm quando comparados aos alunos de outras línguas estrangeiras (LEITE; McCLEARY, 2009).

A promoção do contato usuário/surdo-aluno/ouvinte faz parte, inclusive, das atividades descritas no plano de ensino ou dos enunciados dos docentes. Desses destaco a atividade proposta no plano de ensino da docente Ana "visita a espaços onde encontram-se manifestações da cultura surda", o enunciado da docente Carla "visita em escolas especializadas na educação de surdos e aulas com instrutores surdos convidados”, e o da docente Flávia "como trabalho com um surdo procuro suscitar discussões na classe buscando que os alunos visualizem o conhecimento desse professor".

Para finalizar a discussão dessa subseção tratarei do que tem sido proposto enquanto exercícios sobre os conteúdos práticos da disciplina complementando o que já expus quando tratei dos conteúdos teóricos. Dessa vez, focarei no que pode se configurar como iniciativas que trazem indícios sobre a especificidade da disciplina Libras com relação às demais disciplinas mais tradicionais ou estritamente teóricas dos currículos dos cursos de licenciatura.

Os exercícios descritos foram observados nos planos de ensino ou destacados dos enunciados de alguns docentes e compreendem basicamente as habilidades de compreensão e/ou expressão da Libras.

Uma das atividades mais recorrentes de compreensão é a tradução e/ou interpretação de sinais, sentenças ou pequenos episódios da Libras para a Língua Portuguesa. Já a atividade 
de expressão mais mencionada é a apresentação de diálogos. Estas são atividades avaliativas que também concernem o universo de cursos livres de Libras, fato que confere uma normatividade nos exercícios que são propostos, atualmente, no ensino dessa língua.

No entanto, dois docentes trazem informações sobre exames que apontam para a especificidade dos cursos de licenciatura. No caso, o docente Bruno descreve que " $a$ avaliação fica por conta de uma apresentação em Libras por parte dos alunos, procurando unir com o curso no qual estão se graduando. Se é uma turma de pedagogia, uma música infantil ou uma situação em sala de aula que é dramatizada em Libras. Se é um curso de Educação Física, um esporte adaptado para os surdos, também dramatizado em Libras".

Já a docente Daniela cita que os alunos “[...] ministrarão uma aula em Libras, cada um numa área do conhecimento. Então, qual é o objetivo? Pensar em um plano de aula utilizando a língua de sinais de forma a atender o aluno surdo [...]. [Eles já] começaram a pesquisar sinais, e será uma experiência de situação em sala de aula [...]”."

Esses exercícios de cunho avaliativo denotam que mesmo que a Libras seja ensinada de forma básica, há a preocupação para que a comunicação ocorra e o discente - futuro professor - atue, ou tenha pelo menos a noção inicial de como fazê-lo, em ambientes educacionais que contam com a presença de alunos surdos.

Nesse sentido, Chervel (1988, p. 95) esclarece que:

\begin{abstract}
Se os conteúdos explícitos constituem o eixo central da disciplina ensinada, o exercício é a contrapartida quase indispensável. A inversão momentânea dos papéis entre o professor e o aluno constitui o elemento fundamental [...] Sem o exercício e seu controle, não há fixação possível de uma disciplina. O sucesso das disciplinas depende fundamentalmente da qualidade dos exercícios aos quais elas podem se prestar.
\end{abstract}

Nota-se que os docentes de Libras começam a elaborar exercícios que se prestam ao controle específico do público-alvo da disciplina proposta. A documentação que emerge desses exercícios com o intuito de registrar o saber assimilado pelos alunos, no que concerne aos conteúdos práticos, ocorre, principalmente, por meio de vídeos.

Ou seja, além de toda a documentação e o controle que emerge do "poder da escrita", parafraseando os preceitos já expostos de Foucault (2013c), agora também ocorre a documentação e o controle por meio do "poder da imagem".

Diante do que foi exposto sobre os conteúdos e algumas práticas pedagógicas adotadas na disciplina Libras nas IES percebe-se que esses elementos, tendo como base os objetivos elencados nos planos de ensino e presentes nos enunciados de alguns docentes, podem 
contribuir tanto para consolidação quanto para emergência de ramificações enunciativas sobre a língua de sinais e os surdos. Pois, a institucionalização da Libras, seja em cursos livres, cursos de licenciatura (ou outros cursos de graduação ou extensão) e da oferta, mais recente, de cursos voltados, especificamente, para formação de professores de Libras, como é o caso da licenciatura em Letras-Libras, tem se constituído como um processo de disciplinamento de saberes (FOUCAULT, 1999).

A seguir, farei a discussão dos dados que compreendem como a questão da cultura surda tem sido tratada nas aulas pelos docentes.

6.4 Abordagens sobre a cultura surda

Em complementação ao que discorri até então neste capítulo, discutirei os dados que constam nos enunciados dos docentes sobre as abordagens dos aspectos culturais das comunidades surdas nas aulas.

Para começar destaquei alguns trechos dos enunciados proferidos pelos docentes e que considero como primordiais para compreensão de como a cultura surda tem sido objetivada no discurso que circula na disciplina Libras.

“Aspectos como aquisição da língua pelo sujeito surdo, história da educação do surdo, da necessidade de uma educação específica para esta comunidade, os olhares depositados sobre ela frente uma visão socioantropológica ou medicalizada da condição da surdez e também o processo de retomada do poder de escolha deste sujeito surdo sobre o papel que ele mesmo desempenhará na sociedade. Isso é feito principalmente através de filmes, documentários e aulas teóricas" Ana.

"Procuro apresentar textos de pessoas que concordam com a existência da cultura surda, nos quais eu me incluo, e daqueles que não acreditam que ela exista, ou ela seja distinta da dos ouvintes. Tenho abordado este tema [...] e apresento na visão de Nídia Sá sobre o multiculturalismo. Muito mais do que apenas apertar a luz para chamar outro surdo, ou que o toque se faz necessário, abordo com os alunos que a língua de sinais é o principal meio em que a cultura surda se manifesta. No curso de jornalismo, fiz um documentário chamado 'Nascidos no Silêncio' em que abordo a relação entre filhos ouvintes e pais surdos. Ali estão presentes as diferenças que existem entre a educação de uma família ouvinte e a educação de uma família surda. Mostro que os surdos possuem outros valores, não tão diferentes da pessoa ouvinte, mas que são diferentes e que traz implicações no 
desenvolvimento dos filhos destes casais, sejam eles surdos ou ouvintes. Também cito Stuart Hall, que aborda a questão da identidade nacional e que culturas muitas vezes são construídas para legitimar a história ou a 'história' de um povo” Bruno.

"[...] são discutidas particularidades sobre a cultura surda apresentadas em referências bibliográficas (muitos delas com a autoria de surdos), filmes e relatos de surdos" Carla.

"[...] cultura surda é um conceito muito complexo, se você não tem envolvimento com a área, se você não acompanha a questão histórica, a questão identitária do surdo, é um pouco difícil de entender esse conceito. E eu trabalhei com um livro ['Libras, que língua é essa?'] que aborda essa questão da identidade, da cultura, que acaba aprofundando essas questões. [...] Num primeiro momento os alunos tiveram um pouco de dúvida: 'como outra cultura?'. [...] A própria questão da língua, a língua enquanto traço cultural é importantíssima, há o destaque sobre as manifestações que ocorrem dentro da comunidade, a visão de mundo que ocorre por meio do visual [...]. Acho que são esses três aspectos que abordo mais [...]” Daniela.

“[...] considero que a língua sem as relações socioculturais é estanque e estéril” Emília.

"Falamos da cultura surda, da questão da organização da oração, da forma diferente de compreender uma notícia ou de como muitas vezes o surdo fica excluído da sociedade pelo simples fato de que "ninguém contou para ele a importância daquele assunto". Essa abordagem costuma ocorrer com exemplos vividos pela minha pessoa ou muitas vezes o professor surdo é que vai contanto como ele compreende o mundo. Tivemos já duas palestras com o professor surdo com tradução uma versou sobre a importância da língua de sinais para os surdos e seus aspectos visuais e a segunda foi sobre literatura surda” Flávia.

$\mathrm{Na}$ fundamentação teórica desta pesquisa realizei uma ampla discussão sobre a emergência e consolidação do discurso da diferença que localiza o surdo sob uma perspectiva que valoriza sua língua e que o afirma como alguém que compartilha e produz características culturais próprias. Nesse sentido, na maioria dos enunciados dos docentes fica claro que há a defesa da "existência" da cultura surda e há a preocupação para que os discentes também tenham essa percepção ao se estabelecer analogias ou diferenciações entre os surdos e os ouvintes. 
O discurso que traz o tema cultura surda para as aulas se baseia, primordialmente, na língua de sinais e nas percepções e relações visuais dos surdos com o mundo que os cerca. E quando os docentes mencionam que recorrem às produções acadêmicas, aos filmes e aos relatos de surdos, percebe-se que a cultura surda é, predominantemente, abordada por meio da narrativa.

Porém, não descarto a possibilidade de expressão cultural inconsciente, diante da posição fronteiriça ocupada pelos docentes por meio do contato e convívio que estabelecem diretamente com os surdos, e que poderiam ser constatadas ou não em estudos futuros que primem pela observação e análise das aulas de Libras por professores surdos e ouvintes.

Em algumas pesquisas que tratam das narrativas empreendidas sobre a língua de sinais, seja na educação de surdos ou no ensino dessa língua como L2 para ouvintes, observase a defesa de uma análise cautelosa sobre os discursos que aparecem em diferentes meios e/ou suportes comunicativos e que tratam de questões sobre a surdez.

Nos casos dos discursos que circulam em livros, artigos e ensaios oriundos do meio acadêmico, os defensores da concepção do surdo no contexto da diferença linguística e cultural costumam refutar e/ou problematizar o discurso que prima pela ênfase na deficiência ou na normalidade sociocomunicativa baseada no ouvinte.

No meio acadêmico já existem pesquisas que apontam para a circulação de diferentes discursos em outros meios, como por exemplo, em filmes, que tratam de temáticas que envolvem o surdo.

Sobre alguns desses filmes ${ }^{15}$ Thoma $(2004$, p. 66) faz a seguinte consideração:

\begin{abstract}
Ao analisar o que esses filmes dizem sobre os sujeitos surdos, estamos diante da complexidade em se nomear a alteridade surda e da urgência de uma política cultural que considere as narrativas dos próprios sujeitos surdos, tradicionalmente, descritos a partir dos olhares ouvintes. Isso não significa, entretanto, que esteja supondo que os/as surdos/as nos oferecem uma "saída" mais plausível ou menos colonizada para as representações e discursos que o cinema nos disponibiliza sobre eles e elas. Sei bem que as representações não se mostram puras, assim como também os discursos não são nitidamente demarcados, mas constituídos de uma interdiscursividade.
\end{abstract}

De acordo com os aspectos que os docentes dizem priorizar para esclarecer a questão da cultura surda e as referências a alguns autores/livros específicos que citam em seus enunciados ou que observei nas bibliografias dos planos de ensino, torna-se possível a localização das narrativas que empreenderam dentro de uma prática discursiva que recai na

15 Os filmes analisados pela pesquisadora foram "Filhos do silêncio" (1986, USA), "A música e o silêncio" (1999, USA) e "Som e fúria" (2001, USA). 
afirmação e propagação do que pode ser considerado como normativo no "ser" surdo enquanto diferença linguística e cultural.

Dessa forma, os docentes desta pesquisa, tendem a afastar algumas desconfianças que pairam sobre o fato de ouvintes assumirem as aulas da disciplina Libras. Uma dessas desconfianças é relatada por uma professora ouvinte, conforme consta na pesquisa de Rebouças, mas essa é uma preocupação também expressa por professores surdos:

\begin{abstract}
$\mathrm{Na}$ atualidade, (sem professores, ainda, formados para esse tipo de ensino) não sou a favor [dos professores ouvintes] por acreditar que o conhecimento dos futuros profissionais dos cursos de licenciatura continuará sendo uma visão ouvintista sobre a minoria linguística surda. Essa imagem continuará sendo construída pela narrativa dos ouvintes e não pelos próprios surdos, o que em minha avaliação é um atraso para uma mudança de mentalidade. Mesmo que as pessoas surdas não sejam exímios profissionais de ensino de sua língua, a relação que o ouvinte pode estabelecer com essa pessoa torna-se muito mais produtiva no sentido de "ver", "sentir" as pessoas surdas de uma forma real, e não, através, das narrativas dos ouvintes. (REBOUÇAS, 2009, p. 105).
\end{abstract}

Ao contrário da visão ouvintista expressa na citação, os docentes ao afastarem e/ou problematizarem a normalidade pautada nos ouvintes, acabam contribuindo para assegurar que a cultura surda seja contemplada e aceita discursivamente na disciplina Libras. Alguns desses docentes, inclusive, reconhecem que a cultura surda encontra-se em um campo de tensão no qual os discentes ocupam uma posição mais distante dos locais e dos momentos históricos em que o discurso da cultura surda emergiu e tem ganhado força de verdade, mas que eles, enquanto docentes, estão posicionados de uma maneira mais próxima desse processo, apesar de não ser, necessariamente, igual ao posicionamento ocupado pelos surdos.

A contextualização que precede e/ou afirma a emergência da cultura surda no campo discursivo é tematizada pelos docentes quando, por exemplo, a docente Ana diz que aborda "o processo de retomada do poder", a docente Carla discute "particularidades sobre a cultura surda apresentadas em referências bibliográficas (muitos delas com a autoria de surdos), filmes e relatos de surdos”, a docente Daniela traz referências que "[...] que aborda essa questão da identidade, da cultura [...]”, a docente Flávia diz que mostra alguns exemplos do que ela vivenciou com surdos ou quando o "professor surdo é que vai contanto como ele compreende o mundo”, e, quando, este mesmo professor promove palestras sobre "a importância da língua de sinais para os surdos e seus aspectos visuais e a literatura surda”.

Nesses trechos fica evidente a priorização da narrativa sob o ponto de vista dos surdos mesmo que, em alguns casos, eles não estejam presentes, pessoalmente, nas aulas. 
Além disso, nos trechos acima, não destaquei o enunciado do docente Bruno, pois considero que neste momento devo tratar da questão separadamente, diante do fato do docente ser filho de pais surdos e ser casado com uma mulher surda. Perfil que demonstra um tipo de proximidade com os membros das comunidades surdas que não apareceu entre os outros docentes, já que os mesmos relataram que estabelecem o contato com surdos por meio das relações de amizade e/ou profissionais.

Os dados conferidos ao docente tratam, de forma elucidativa, a maneira com que ele constrói o embasamento para as questões que permeiam a cultura surda nas aulas. E o que chamou mais atenção foi: o uso de textos de autores que defendem a "existência" da cultura surda no campo dos Estudos Surdos, como o exemplo que deu sobre a Nídia Sá (pesquisadora que tem uma filha surda); a menção de um autor que é da área dos Estudos Culturais (Stuart Hall); e a afirmação do pertencimento do próprio docente, enquanto pesquisador, ao campo discursivo que defende a cultura surda.

O laço que Bruno mantém com surdos desde o nascimento colaborou para que o mesmo não apenas se tornasse membro da comunidade surda, mas também se engajasse profissional e politicamente nos movimentos afirmativos dessa comunidade. Esse engajamento político pode ser observado quando o docente, diante da sua inserção no meio acadêmico, elabora um documentário que traz uma temática que se relaciona com sua história de vida e demonstra as possíveis tensões nas relações educacionais e culturais que envolvem familiares surdos e familiares ouvintes com seus filhos.

$\mathrm{O}$ docente adotando essa postura demonstra que além de incorporar, disseminar e afirmar um conjunto de enunciados em suas aulas, também é produtor de enunciados que se ramificam, de certa forma, do discurso defendido.

Ao fazer essa analogia não estou sancionando que os demais docentes desta pesquisa também não sejam produtores de enunciados que se agregam ao discurso da diferença linguística e cultural, mesmo porque a maioria também desenvolveu - ou desenvolve pesquisas na área da surdez, segundo o vínculo que apresentaram em suas formações. Porém, nessa análise considero apenas o que foi dito por cada um deles.

Para finalizar a discussão sobre os dados da pesquisa, a seguir farei uma explanação sobre as percepções que os docentes têm sobre os discentes ao longo do processo de ensinoaprendizagem da disciplina Libras. 
6.5 A permeabilidade dos discursos docentes

Para finalizar este capítulo, a análise dessa última seção comportará as percepções que os docentes expuseram sobre a apreensão discursiva demonstrada pelos discentes ao longo do período letivo em que as aulas da disciplina Libras se desenvolveram.

Lembrando ao leitor que as docentes Daniela e Emília contemplaram o que observaram durante o bimestre letivo, a docente Ana sobre o semestre, e os docentes Bruno, Carla e Flávia se basearam em observações de períodos que envolveram diferentes turmas, pois a atuação deles na disciplina Libras das IES pesquisadas variou de dois a seis anos. Isto, obviamente, na época em que os dados foram coletados.

O primeiro dado que pode ser destacado sobre as percepções que os docentes tiveram sobre os discentes ao longo das aulas da disciplina Libras é que a maioria dos alunos teve uma boa receptividade do discurso que proclama o saber que permeia os surdos e a língua de sinais, dentro de uma perspectiva da diferença linguística e cultural. Inclusive, esses mesmos discentes demonstram a tendência para desconstrução dos saberes que eles tinham sobre os surdos e a Libras antes da disciplina, e a assimilação dos saberes propagados pelos docentes, conforme atestam os trechos abaixo:

"No decorrer do curso, existe muita surpresa e também solidariedade sobre aspectos antes desconhecidos [...]. De forma geral, boa parte dos alunos mostra interesse em conhecer mais sobre a comunidade surda e sua língua” Ana.

" $E$ muito bom ver paradigmas serem desconstruídos e remontados diante dos seus olhos. [...] Nos textos que me apresentam fica nítida a mudança de pensamento em relação à inclusão de pessoas com deficiência” Bruno.

"Inicialmente, suas falas revelam inúmeros mitos relacionados à surdez e à Libras e o desconhecimento de particularidades relacionadas à cultura e identidade surda, aspectos esses que são superados ao longo do curso da disciplina” Carla.

“[...] Os alunos da pedagogia veem como extremamente necessário porque eles irão trabalhar com educação inclusiva e se depararão um dia com o surdo, na sala de aula ou fora da sala, então eles acham que precisam desse preparo [...], eles não tinham essa percepção inicial, agora já tem, [e dizem] 'essa disciplina deveria ter dois semestres' [...]'” Daniela.

“[...] O senso comum prevalece e desmitificar isto proporciona uma nova abordagem dos alunos não somente frente aos surdos como também sobre as dinâmicas inter-relacionais frente às diferenças " Emília. 


\section{"[...] a maioria dos alunos inicia o semestre letivo tendo algumas ideias e ao} término do mesmo a grande maioria modifica suas perspectivas [...] ” Flávia.

Nos destaques que fiz nos enunciados, de forma complementar ao que foi proferido nos dados sobre os objetivos dos docentes sobre a disciplina, dentre os quais se anunciava a necessidade de modificar as concepções proferidas pelos discentes por serem consideradas "inadequadas", agora os mesmos docentes localizam essa "inadequação" no passado. Depreende-se daí, que o percurso desenvolvido nas aulas tem sido capaz de promover a verdade conferida ao saber defendido na prática pedagógica.

A permeabilidade do saber propagado ao longo das aulas é exemplificada pelos docentes quando estes trazem alguns enunciados que circulam entre os discentes, como:

"Os alunos chegam dizendo várias terminologias que hoje consideramos erradas, como surdo-mudo, portador de deficiência, entre outros, e ao final do semestre eles já começam a falar surdo, e pessoa com deficiência. Já ouvi alunos comentarem que corrigem os colegas que usam a terminologia errada” Bruno.

"[...] [sobre o que dizem os alunos da Pedagogia] 'essa disciplina deveria ter dois semestres' [...] [sobre o relato de uma aluna que já sabia Libras e queria cursar a disciplina como ouvinte] Ela falou: 'professora, eu estou gostando muito porque tem toda uma parte que entra na Libras que eu não sabia, eu não estudei textos teóricos, eu não tenho essa bagagem, eu só conheço a parte prática e só conheço a surdez!'. E é uma das melhores alunas, ela já sabe, participa de tudo [...]” Daniela.

"[...] um aluno que o pai, após a aposentadoria, estava bebendo muito e se afastando da família. Após uma aula ele relatou que percebeu que o afastamento do pai não era unilateral, mas que a família o havia afastado por ele estar apresentando uma perda auditiva que o distanciava da língua e por consequência das relações. A partir das aulas o discente conseguiu relacionar o fato não somente como pessoal, mas trouxe reflexões pessoais bastante ricas" Emília.

Em alguns desses relatos observa-se a contribuição dos discentes nas relações de poder e saber estabelecidas na disciplina. De acordo com Chervel (1988, p. 84):

O "trabalho" - no sentido forte - do mestre é o da tensão de um corpo a corpo com o grupo. O grupo em si mesmo, enquanto tal, constitui uma peça essencial do dispositivo disciplinar. Num dado momento, é um dos alunos que, melhor do que os outros, seja porque é mais forte, seja porque é mais fraco, expressará as dificuldades encontradas, e permite assim ao conjunto se beneficiar dos complementos da explicação. Noutro momento, é o grupo que serve de substituto à palavra do mestre diante dos alunos em dificuldade, pois é melhor que eles próprios afastem sozinhos 
os obstáculos. A função pedagógica do grupo é constante, ainda que disfarçada, até mesmo clandestina.

Os discentes que aparecem nos exemplos mencionados pelos docentes demonstram que além de incorporarem o discurso das aulas, tomando como premissa o que foi citado por Chervel (1988), em alguns momentos substituem os docentes ao reafirmarem e propagarem esse discurso entre os colegas, assumindo uma função pedagógica dentro do dispositivo disciplinar.

No entanto, as tensões e os processos de resistências frente ao discurso disseminado na disciplina também foram identificados por meio dos trechos proferidos por duas docentes:

“[...] paira certa incompreensão sobre outros aspectos, tais como sobre os grupos que rejeitam terapias e cirurgias corretivas” Ana.

"[...] ao término alguns continuam achando que 'Libras é bonitinho' e que os 'surdos-mudos' devem aprender a falar para se comunicar’' Flávia.

Em ambos, verifica-se que alguns alunos não incorporaram ou aceitaram tacitamente o que foi propagado nas aulas e ainda retém o saber que se vincula ao discurso pautado na deficiência e na normalidade sociocomunicativa baseada no ouvinte.

Este fato também foi demonstrando nos enunciados de alguns discentes, pertencentes à pesquisa de Almeida (2012), que ao término da disciplina fizeram algumas considerações do que compreendiam sobre a Libras. A autora, em sua análise aponta que:

\footnotetext{
Se por um lado temos o esclarecimento de alguns equívocos em relação à Libras, de outro, não podemos ignorar as expressões "portadores de deficiência" (A5) e "pessoas mudas e surdas" em relação aos surdos, bem como a visão limitada de que é uma língua apenas para comunicação entre as pessoas surdas. Nos chama a atenção o fato de que ao se referir as pessoas surdas alguns alunos utilizem expressões inadequadas, visto que tiveram um semestre de formação na referida disciplina com uma professora surda, além de outras disciplinas relacionadas à educação especial, anteriores à disciplina Libras em sua grade curricular. (ALMEIDA, 2012, p. 56).
}

A resistência ao discurso adotado pelos docentes pode ser relacionada aos diferentes perfis dos discentes e aos aspectos subjetivos que estes se baseiam ao entrar em contato com uma disciplina que envolve a língua e cultura oriundas de uma comunidade diferente, e que mesmo estando próxima geograficamente pode não ser percebida, em suas peculiaridades, em locais e situações cotidianas. 
Gesser (2012), de posse das observações que realizou em dois contextos em que a Libras era ensinada formalmente elabora um resumo que traz alguns apontamentos sobre as relações que os ouvintes podem estabelecer na e com a Libras:

[...] desafiados, [os alunos ouvintes] demonstravam medo, ansiedade, incapacidade,
falta de coordenação motora, cansaço físico e mental, mas desenvolviam estratégias
e mostravam atitudes positivas ao lidar com uma língua espaço-visual; culpados,
vivenciavam o remorso e a indignação com a situação enfrentada pelos surdos em
sua fase de escolarização; solidários, colocavam-se na posição dos próprios surdos
em alguns momentos interacionais na sua relação de aprendizagem da Libras;
preconceituosos, aberta ou veladamente, mostravam-se também desconfiados com
relação ao surdo e suas línguas; estrangeiros, deslocavam-se entre uma Libras
simplesmente outra língua, e uma língua muito alheia e mesmo exótica. (GESSER,
2012, p. 179).

Mesmo que na minha pesquisa não tenha focado nos discentes, as asserções citadas por Almeida (2012) e Gesser (2012) podem ser associadas às descrições de alguns docentes.

Foucault (2006, p. 232) afirma que "as relações de poder são relações de forças, enfrentamentos, portanto, sempre reversíveis. Não há relações de poder que sejam completamente triunfantes e cuja dominação seja incontornável”. E as resistências fazem parte dessas relações nas quais os discursos circulam e se modificam nas tentativas que expressam uma vontade de verdade.

Nesse sentido, finalizo este capítulo considerando que há a circulação e a permeabilidade do discurso defendido na disciplina entre os discentes, porém isso não ocorre em fronteiras claramente delineadas e homogêneas. Pois, mesmo que alguns alunos demonstrem a incorporação e contribuição para afirmação do saber que está em jogo, não se pode ignorar o fato de que outros resistem a esse discurso ao se apoiarem em outro conjunto de enunciados, fato que corrobora com as relações de poder e saber que se inscrevem na disciplina Libras. Logo, o que tem sido defendido como verdade pelos docentes situa-se em um território de tensão em que não se pode contar com o completo triunfo, mas com as possibilidades de reversibilidade. 


\section{CONSIDERAÇÕES FINAIS}

Todo professor de língua deve sentir-se encorajado frente à popularidade e aceitação de uma língua antigamente negligenciada, especialmente, em se tratando de uma língua que pertence ao nosso próprio meio.

Wilcox \& Wilcox

Inicialmente esta pesquisa pautou-se numa perspectiva um pouco mais conceitual sobre o conjunto de enunciados sobre o termo cultura e como o saber que se atribuiu e se concentrou nesse termo reuniu diferentes áreas do conhecimento, inclusive, dentro de um campo específico, os Estudos Culturais. Concebi esta área como profícua para a problematização do que se pode entender por cultura, principalmente, quando há uma preocupação para que a mesma não se apoie, exclusivamente, nas construções discursivas oriundas dos grupos majoritários.

Logo em seguida, associei a pesquisa não apenas aos Estudos Culturais, mas também aos Estudos Surdos e numa perspectiva analítica que considera o discurso e as relações de poder e saber em torno da ideia de cultura surda, ao me basear em algumas obras de Michel Foucault.

O processo reflexivo adotado me permitiu compreender a cultura surda como uma construção discursiva oriunda das comunidades surdas e que aos poucos tem sido enunciada em outros meios e áreas da sociedade, especialmente, no meio educacional/acadêmico.

Tal construção, no contexto das relações de poder e saber vigentes na sociedade atual, tem se direcionado, predominantemente, para afirmação do "ser" surdo enquanto uma diferença que culmina em todo um processo de constituição tanto das identidades individuais quanto das identidades sociais dos membros das comunidades surdas, da produção intelectual e cultural oriunda dessa comunidade e do uso de uma língua de modalidade visual-motora.

Considero que a Libras, ao se configurar como um símbolo da resistência, ao se tornar pauta das reivindicações e dos movimentos políticos das comunidades surdas brasileiras, ao ser afirmada como uma das principais marcas culturais dessas comunidades, ao ser declarada como a L1 na proposta educacional bilíngue, ao ser reconhecida com língua no meio acadêmico e legislativo e, ao ser incluída no Ensino Superior, tem adquirido maior 
importância e visibilidade nas práticas discursivas que permeiam a subjetivação dos sujeitos surdos e de alguns ouvintes.

As dinâmicas que compreendem as relações de poder e saber em torno dos surdos e da língua de sinais englobam disputas, tensões, resistências, regularidades enunciativas e normas que foram amplamente abordadas em toda fundamentação teórica e, no último capítulo, com foco nos cursos superiores de licenciatura.

Nesse sentido, faço uma síntese delineando as principais regularidades dos enunciados presentes nos dados que compreenderam o processo investigatório que estão em consonância com os enunciados da fundamentação teórica, tomando como premissa os perfis dos sujeitos do discurso, no caso, os docentes participantes da pesquisa, a institucionalização da Libras nos cursos das IES e a percepção dos docentes sobre os discentes, no que concerne à todas as práticas discursivas desenvolvidas nas aulas.

Por meio dos dados analisados se torna possível afirmar que a disciplina Libras pode contribuir para circulação do discurso da diferença linguística e cultural das comunidades nos cursos superiores de licenciatura, na medida em que:

- Os docentes, enquanto sujeitos do discurso, demonstram vínculo formativo, profissional e pessoal com os surdos e a Libras;

- Em suas práticas os docentes estabelecem normatividades nos objetivos, conteúdos, estratégias e exercícios que se fundamentam no discurso que se filia, predominantemente, aos saberes que permeiam os surdos, a história da educação de surdos, as comunidades, identidades e culturas surdas e a Libras e sua gramática;

- O processo de institucionalização da disciplina tem permitido a introdução, circulação, disseminação e ampliação das práticas discursivas que giram em torno do surdo e da língua de sinais, em alguns casos, em iniciativas que transcende o espaço da sala de aula e o corpo discente;

- O uso e o ensino da Libras fazem parte das aulas, priorizando-se o nível básico de compreensão e expressão;

- Alguns elementos que compõe a prática pedagógica são normatizados com o intuito de problematizar e/ou desconstruir saberes pautados no discurso da deficiência e da normalidade sociocomunicativa baseada nos ouvintes; 
- A cultura surda, além de fazer parte da base discursiva geral, tem seus traços e produções abordados por meio de estratégias que valorizam o ponto de vista dos surdos;

- De acordo com os docentes, os discentes, em sua maioria, demonstram mudança de perspectiva discursiva e se tornam solidários e/ou disseminadores do conjunto de enunciados proposto nas aulas.

Diante do que foi exposto verifica-se que os papéis adotados pelos docentes são essenciais, no momento atual e nas perspectivas de ensino da Libras, no processo de disciplinamento de saberes nas IES e, de forma projetiva, nos ambientes institucionais em que os discentes da licenciatura atuarão. Principalmente, porque "todo sistema de educação é uma maneira política de manter ou de modificar a apropriação dos discursos, com os saberes e os poderes que eles trazem consigo" (FOUCAULT, 2010, p. 44). Logo, quando os docentes se engajam na modificação e/ou na problematização de um determinado discurso que circula nas IES e/ou na sociedade majoritariamente ouvinte e trabalham em torno do discurso que circula em prol das comunidades surdas, podem favorecer os processos de apropriação social do mesmo.

Considero que as discussões realizadas ao longo desta pesquisa podem colaborar para algumas reflexões que permeiam a Libras no Ensino Superior, mas diante do universo mais restrito e qualitativo os apontamentos que realizei não são passíveis de generalizações e aplicações em todo e qualquer contexto de ensino da língua de sinais.

No entanto, os enunciados dos docentes que compartilharam suas experiências trouxeram várias assertivas para a questão que me afligia, enquanto docente de Libras, sobre as práticas discursivas adotadas na disciplina em outras IES. E, pensando no que realizo nas minhas aulas, o que tenho a acrescentar é que foi extremamente positivo me identificar com vários apontamentos realizados por esses profissionais.

Como exemplo, cito o fato da carga horária ser insuficiente para tratar de temas que ultrapassam o desenvolvimento básico da Libras e que precisam contemplar, principalmente, as questões sociais, políticas, identitárias, culturais e educacionais de seus usuários. A disciplina que ministro começou com 40h/a em todos os cursos de licenciatura e a partir do primeiro semestre deste ano a carga horária foi para $80 \mathrm{~h} / \mathrm{a}$ em três, dos cinco cursos em que 
atuo. Boa parte dessa conquista se relaciona à receptividade e cooperação dos discentes que assimilaram e se tornaram disseminadores das práticas discursivas empreendidas nas aulas.

Aproveito para destacar que sempre ministrei as aulas utilizando a Libras e, quando necessário, a modalidade escrita da Língua Portuguesa. A modalidade oral nunca fez parte da minha prática, mas isso não significa que não esteja presente entre os alunos, afinal, é a L1 deles. Priorizo o desenvolvimento da língua de sinais desde o primeiro dia de aula criando situações dialógicas e dinâmicas que envolvam certo domínio lexical contextualizado. Ao conduzir as aulas dessa forma percebo que os alunos acabam desenvolvendo uma "comunicação dirigida" conforme os temas trabalhados, e uma "comunicação espontânea" para tratar de assuntos da rotina de sala de aula e da IES, para me informarem alguma situação atípica e para estabelecerem conversas sobre o cotidiano deles ou para perguntarem algo sobre o meu.

Outra situação que gostaria de compartilhar, e que alguns docentes da pesquisa realizam de forma semelhante, é a proposição de um exercício ao final da disciplina que atende a especificidade de cada curso de licenciatura, já que os demais exercícios são apresentações pessoais ou diálogos, no que concerne ao conteúdo prático, e no teórico são sínteses, resenhas, seminários e avaliações escritas. Em todos os cursos solicito aos alunos que elaborem um plano de aula e apresentem uma parte do mesmo, em Libras, simulando uma situação real de sala de aula e contando com o apoio de recursos visuais, se acharem conveniente para o assunto escolhido. Essa é atividade que os alunos se sentem mais desafiados, mas que o resultado é muito positivo para o uso e desenvolvimento da língua, pois eles acabam pesquisando em casa muitos sinais para a aula e entram em contato com diversos vídeos, dicionários e aplicativos em Libras, e para o processo reflexivo da mesma e da educação de surdos, já que depois eles fazem uma autoavaliação, por escrito, sobre o que planejaram e apresentaram, após minhas observações e comentários.

No que se refere à cultura surda, além de fazer parte da base discursiva geral, essa cultura é abordada, principalmente, por meio de textos, documentários e vídeos produzidos por surdos, e de relatos sobre o que observo no convívio com alunos e amigos surdos. Além disso, sempre enfatizo a necessidade dos discentes da disciplina ultrapassarem o uso inicial da Libras na IES e estabelecerem o contato com a comunidade surda em seus diferentes pontos de encontro ou em espaços em que há a presença/atuação de membros dessa comunidade. 
Nesse sentido, muitos são os discentes que durante ou após a disciplina contam as primeiras aproximações que tiveram com os surdos nos mais diversos ambientes sociais; os cursos de aprofundamento de Libras que decidiram realizar; as orientações aos familiares de alunos surdos que tiveram na escola ou nas instituições que começaram a atuar - ou atuam como estagiários ou profissionalmente; o processo de mudança na maneira de olhar para os surdos e a língua de sinais, e a forma com que envolveram seus familiares e/ou amigos nessa empreitada.

Também não poderia deixar de registrar que há alguns poucos discentes que não pactuam com as práticas das aulas, principalmente, ao encararem a disciplina, literalmente, como uma obrigação presente no currículo do curso e/ou demonstrarem certa resistência com relação à ausência do uso da Língua Portuguesa na modalidade oral na minha atuação docente e na vida de muitos surdos que priorizam a língua de modalidade visual-motora.

Para finalizar, concluo esta dissertação contando com a possibilidade de ter contribuído para ampliação das reflexões e problematizações que estão em jogo nas relações de poder e saber que permeiam as línguas de sinais, culturas e comunidades surdas. Dos dados e discussões servirem de referencial aos professores de Libras para que possam constatar, comparar e até mesmo contestar o que tem sido realizado por outros colegas de profissão em outras IES, ou que possam auxiliar direta e/ou indiretamente no desenvolvimento/consolidação de normatividades sobre o processo de ensino-aprendizagem da Libras em cursos superiores de licenciatura.

O fato é que o ensino da Libras para ouvintes nas IES, em processo de introdução e estabilização no contexto brasileiro, é uma temática recente e um terreno fértil para empreendimentos investigativos, dos quais podem se relacionar, ramificar ou emergir do discurso que preza pela diferença linguística e cultural das comunidades surdas ou de outros domínios discursivos. 


\section{REFERÊNCIAS}

ALBRES, N. de A. Ensino de Libras como segunda língua e as formas de registrar uma língua visuo-gestual: problematizando a questão. ReVEL, v. 10, n. 19, p. 125-149, 2012. Disponível em: 〈http://www.revel.inf.br/files/6e9e138e1df0292c48e355324465cb64.pdf> Acesso em: 29 mar. 2014.

ALMEIDA, J. J. F. de. Libras na formação de professores: percepções de alunos e da professora. 150 f. 2012. Dissertação (Mestrado em Educação) - Universidade Estadual de Londrina, Londrina, 2012.

ASSOCIAÇÃO Brasileira de otorrinolaringologia e cirurgia cérvico-facial. ORL em prol da informação na TV Globo. São Paulo. Disponível em:

<http://www.sborl.org.br/conteudo/secao_detalhes.asp?s=51\&id=2092> Acesso em: 10 jun. 2013.

BEHARES, L. Línguas e identificações: as crianças surdas entre o "sim" e o "não". In:

SKLIAR, C. (Org.). Atualidades da educação bilíngue para surdos. 2. ed. Porto Alegre: Mediação, 2009. v. 2. p. 131-147.

BERTHIER, F. O Abade Sicard: célebre professor de surdos mudos sucessor imediato do Abade de L'Épée. [1973]. In: CARVALHO, P. V. de. A herança de Abade de L' Épée na viragem do século XVIII para o século XIX. Lisboa: The factory, 2013. p. 29-130.

BHABHA, H. K. O local da cultura. 2. ed. Belo Horizonte: Editora UFMG, 2013.

BOGDAN, R. C.; BIKLEN, S. K. Investigação qualitativa em educação: uma introdução à teoria e aos métodos. Porto: Porto Editora, 1994.

BOTELHO, P. Surdos oralizados e identidades surdas. In: SKLIAR, C. (Org.). Atualidades da educação bilíngue para surdos. 2. ed. Porto Alegre: Mediação, 2009. p. 149-164.

BRASIL. Lei $\mathbf{n}^{\mathbf{0}} \mathbf{1 0 . 0 9 8}$, de 19 de dezembro de 2000. Estabelece normas gerais e critérios básicos para a promoção da acessibilidade das pessoas portadoras de deficiência ou com mobilidade reduzida, e dá outras providências. Brasília-DF, 2000. Disponível em: <http://www.planalto.gov.br/ccivil_03/leis/110098.htm>. Acesso em: 10 fev. 2003.

BRASIL. Ministério da Educação. Secretaria de Educação Especial. Lei no 10.436, de 24 de abril de 2002. Dispõe sobre a Língua Brasileira de Sinais - LIBRAS e dá outras providências. 
Brasília-DF, 2002. Disponível em:

<http://www.planalto.gov.br/ccivil_03/LEIS/2002/L10436.htm >. Acesso em: 10 fev. 2003.

BRASIL. Ministério da Educação. Secretaria de Educação Especial. Decreto no 5.626, de 22

de dezembro de 2005. Regulamenta a Lei $n^{\circ}$ 10.436, de 24 de abril de 2002. Brasília-DF, 2005. Disponível em:

<http://www.planalto.gov.br/ccivil_03/_Ato2004-2006/2005/Decreto/D5626.htm>. Acesso em: 10 mar. 2006.

BRASIL. Conselho Nacional de Educação. Resolução CNE/CP n 1, de 15 de maio de 2006. Diretrizes Curriculares Nacionais para o Curso de Graduação em Pedagogia Licenciatura. Brasília-DF, 2006. Disponível em:

<http://portal.mec.gov.br/cne/arquivos/pdf/rcp01_06.pdf>. Acesso em 31 de mar. 2013.

BRASIL. Lei $\mathbf{n}^{\circ} \mathbf{1 2 . 3 1 9}$, de $\mathbf{1}^{\mathbf{0}}$ de setembro de 2010. Regulamenta a profissão de Tradutor e Intérprete da Língua Brasileira de Sinais - LIBRAS. Brasília-DF, 2010. Disponível em: <http://www.planalto.gov.br/ccivil_03/_Ato2007-2010/2010/Lei/L12319.htm Acesso em: 18 de set. de 2010.

CAETANO, C. R. de P. B. LIBRAS no ensino superior: futuras pedagogas numa aprendizagem viso/espacial. Viçosa: Universidade Federal de Viçosa, 2011. Disponível em: <http://www.webartigos.com/articles/59716/1/LIBRAS-no-ensino-superior-Futuraspedagogas-numa-aprendizagem-visoespacial/pagina1.html>. Acesso em: 14 mar. 2011.

CALDAS, W. Cultura. 4. ed. São Paulo: Global, 1991.

CAPOVILLA, F. C. A evolução nas abordagens à educação da criança surda: do oralismo à comunicação total, e desta ao bilinguismo. In: CAPOVILLA, F. C.; RAPHAEL, W. D. (Eds.). Dicionário enciclopédico trilíngue da Língua de Sinais Brasileira. São Paulo: EDUSP: Impressa Oficial do Estado, 2001. v. 2 p. 1479-1490.

CAPOVILLA, F. C. et al. A escrita visual direta de sinais sign writing e seu lugar na educação da criança surda. In: CAPOVILLA, F. C.; RAPHAEL, W. D. (Eds.). Dicionário enciclopédico trilíngue da Língua de Sinais Brasileira. São Paulo: EDUSP: Impressa Oficial do Estado, 2001. v. 2 p. 1491-1496.

CARVALHO, P. V. de. A herança de Abade de L' Épée na viragem do século XVIII para o século XIX. Lisboa: The factory, 2013.

CEVASCO, M. E. Dez lições sobre estudos culturais. São Paulo: Boitempo, 2008. 
CHERVEL, A. L'histoire des disciplines scolaires: réflexions sur un domaine de recherche.

Histoire de l'éducation. v. 38, n. 38, p. 59-119, mai. 1988. Disponível em:

$<$ http://www.persee.fr/web/revues/home/prescript/article/hedu_0221-

6280_1988_num_38_1_1593> Acesso em: 03 ago. 2013.

CICCONE, M. Prefácio. In: CICCONE, M. Comunicação total: introdução, estratégias a pessoa surda. 2. ed. Rio de Janeiro: Cultura médica, 1996.

CRUZ, C. R. Avaliação e intervenção da linguagem na criança surda em uma abordagem bilíngue. In: MOURA, M. C.; CAMPOS, S. R. L. CAMPOS; VERGAMINI, S. A. A. (Orgs.) Educação para surdos: práticas e perspectivas II. São Paulo: Santos, 2011. p. 31-48.

DALLAN, M. S. S. Análise discursiva dos estudos surdos em educação: a questão da escrita em sinais. Campinas, SP: Mercado das Letras, 2013.

DORZIAT, A. Bilinguismo e surdez: para além de uma visão linguística e metodológica. In: SKLIAR, C. (Org.). Atualidades da educação bilíngue para surdos. Porto Alegre: Mediação, 2009. v. 1. p. 27-40.

DUBAR, C. A socialização: construção das identidades sociais e profissionais. São Paulo: Martins Fontes, 2005.

DUSCHATZKY, S.; SKLIAR, C. O nome dos outros. Narrando a alteridade na cultura e na educação. In: LARROSA, J.; SKLIAR, C. (Orgs.). Habitantes de Babel: políticas e poéticas da diferença. Belo Horizonte: Autêntica, 2001. p. 119-138.

ESCOLANO, A. Arquitetura como programa: espaço-escola e currículo. In: VIÑAO FRAGO, A.; ESCOLANO, A. Currículo, espaço e subjetividade: a arquitetura como programa. 2. ed. Rio de Janeiro: DP\&A, 2001. p. 19-57.

FERNANDES, E. Linguagem e surdez. Porto Alegre: Artmed, 2003.

FERREIRA-BRITO, L. Por uma gramática da língua de sinais. Rio de Janeiro: Tempo Brasileiro, 1995.

FOUCAULT, M. Em defesa da sociedade: curso no Collège de France (1975-1976). São Paulo: Martins Fontes, 1999. 
FOUCAULT, M. O sujeito e o poder. In: DREYFUS, H. L.; RABINOW, P. Michel Foucault: uma trajetória filosófica para além do estruturalismo e da hermenêutica. 3 . ed. Rio de Janeiro: Forense Universitária, 2013a. p. 273-295.

FOUCAULT, M.; MOTTA, M. B. da (Org.). Estratégias, poder-saber. Rio de Janeiro: Forense Universitária, 2006.

FOUCAULT, M. Microfísica do poder. 20. ed. Rio de Janeiro: Edições Graal, 2004.

A ordem do discurso. 20. ed. São Paulo: Edições Loyola, 2010.

A arqueologia do saber. 8. ed. Rio de Janeiro: Forense Universitária, 2013 b.

Vigiar e punir: nascimento da prisão. 41. ed. Petrópolis, RJ: Vozes, 2013c.

GARCIA, B. G. de. O multiculturalismo na educação dos surdos: a resistência da diversidade para a educação dos surdos. In: SKLIAR, C. (Org.). Atualidades da educação bilíngue para surdos. Porto Alegre: Mediação, 2009. v. 1. p. 149 -162.

GESSER, A. O ouvinte e a surdez: sobre ensinar e aprender a LIBRAS. São Paulo: Parábola Editorial, 2012.

GIROLETTI, M. de F. P. Cultura surda e educação escolar Kaingang. 2008. 208 f. Dissertação (Mestrado em Educação) - Centro de Ciências da Educação, Universidade Federal de Santa Catarina, Florianópolis, 2008.

GOFFMAN, E. Estigma: notas sobre a manipulação da identidade deteriorada. 4. ed. Rio de Janeiro: LTC, 1988.

GOMES, A. P. G. A invenção da cultura surda e seu imperativo no plano conceitual. In: KARNOPP, L.; KLEIN, M.; LUNARDI-LAZZARIN, M. L. Cultura surda na contemporaneidade: negociações, intercorrências e provocações. Canoas: Ed. ULBRA, 2011. p. 121-135.

HALL, S. The centrality of culture: notes on the cultural revolutions of our time. In: THOMPSON, K (ed.). Media and cultural regulation. London, Thousand Oaks, New Delhi: The Open University; SAGE Publications, 1997. (Cap. 5) 
A identidade cultural na pós-modernidade. 11. ed. Rio de Janeiro: DP\&A, 2006.

2009.

Da diáspora: identidades e mediações culturais. Belo Horizonte: Editora UFMG,

Quem precisa de identidade? In: SILVA, T. T. da (Org.); HALL, S.; WOODWARD,

K. Identidade e diferença: a perspectiva dos estudos culturais. 12. ed. Petrópolis, RJ: Vozes, 2012. p. 103-133.

ISAIA, S. M. de. A. Professor universitário no contexto de suas trajetórias como pessoa e profissional. In: MOROSINI, M. C. (Org.). Professor do ensino superior: identidade, docência e formação. Brasília: Instituto Nacional de Estudos e Pesquisas Educacionais, 2000. p. 21- 33. Disponível em:

<http://www.iprede.org.br/upload/arquivo_download/2007/Professor\%20do\%20Ensino\%20S uperior.pdf>. Acesso em: 08 de abr. de 2013.

JOKINEN, M. Alguns pontos de vista sobre a educação dos surdos nos países nórdicos.

SKLIAR, C. (Org.). Atualidades da educação bilíngue para surdos. 3. ed. Porto Alegre: Mediação, 2009. v.1. p. 105-127.

KARNOPP, L. B.; KLEIN, M.; LUNARDI-LAZZARIN, M. L. Produção, circulação, consumo da cultura surda brasileira. In: KARNOPP, L. B.; KLEIN, M.; LUNARDILAZZARIN, M. L. (Orgs.). Cultura surda na contemporaneidade: negociações, intercorrências e provocações. Canoas: Ed.ULBRA, 2011. p. 15-28.

KLEIN, M. Cultura surda e inclusão no mercado de trabalho. In: THOMA, A. da S.; LOPES, M. C. (Orgs.). A invenção da surdez: cultura, alteridade, identidades e diferença no campo da educação. Santa Cruz do Sul: EDUNISC, 2004. p. 83-99.

KYLE, J. O ambiente bilíngue: alguns comentários sobre o desenvolvimento do bilinguismo para surdos. In: SKLIAR, C. (Org.). Atualidades da educação bilíngue para surdos. Porto Alegre: Mediação, 2009. v. 1. p. 15-40.

LANE, H. A máscara da benevolência: a comunidade surda amordaçada. Lisboa: Instituto Piaget, 1992.

LEITE, T. de A.; McCLEARY, L. Estudo em diário: fatores complicadores e facilitadores no processo de aprendizagem da Língua de Sinais Brasileira por um adulto ouvinte. In:

QUADROS, R. de M.; STUMPF, M. R. (Orgs.). Estudos surdos IV. Petrópolis, RJ: Arara Azul, 2009. p. 241-276. 
LEITE, T. de A. O ensino de segunda língua com foco no professo: história oral de professores surdos de língua brasileira de sinais. 2004. 239 f. Dissertação (Mestrado em Letras) - Faculdade de Filosofia, Letras e Ciências Humanas, Universidade de São Paulo, São Paulo, 2004. Disponível em: <http://www.teses.usp.br/teses/disponiveis/8/8147/tde22082006-102110/pt-br.php> Acesso em: 09 mar. 2013.

LOBATO, L. Fala Raul... [Blog]. São Paulo, 06 mai. 2009. Disponível em: <http://desculpenaoouvi.laklobato.com/2009/05/06/falaraul/> Acesso em: 07 jun. 2014.

Porque é importante divulgar a existência dos surdos oralizados. Blog. Disponível em: <http://desculpenaoouvi.laklobato.com/2011/10/26/por-que-e-importantedivulgar-a-existencia-dos-surdos-oralizados/> Acesso em: 07 jun. 2014.

LODI, A. C. B. Plurilinguismo e surdez: uma leitura bakhtiniana da história da educação dos surdos. Educação e pesquisa, São Paulo, v. 31, n. 3, p. 409-424, set./dez. 2005.

LODI, A. C. B.; HARRISON, K. M. P.; CAMPOS, S. R. L. de. Letramento e surdez: um olhar sobre as particularidades do contexto educacional. In: LODI, A. C. B.; MÉLO, A. D. B. de; FERNANDES, E. (Orgs.). Letramento, bilinguismo e educação de surdos. Porto Alegre: Mediação, 2012. p. 11-24.

LOPES, M. C. A natureza educável do surdo: a normalização surda no espaço da escola de surdos. In: THOMA, A. da S.; LOPES, M. C. (Orgs.). A invenção da surdez: cultura, alteridade, identidades e diferença no campo da educação. Santa Cruz do Sul: EDUNISC, 2004. p. 33-55.

Relações de poderes no espaço multicultural da escola para surdos. In: Skliar, C. A surdez: um olhar sobre as diferenças. 3. ed. Porto Alegre: 2005. p. 105-121.

LOPES, M. C.; VEIGA-NETO, A. Marcadores culturais surdos: quando eles se constituem no espaço escolar. Perspectiva, Florianópolis, v. 24, n. Especial, p. 81-100, jun./dez. 2006.

Disponível em: < https://periodicos.ufsc.br/index.php/perspectiva/article/view/10541> Acesso em: 11 nov. 2012.

MATOS, M. F. A ideia de cultura surda atribuída por professores de alunos surdos. In: Congresso Brasileiro de Educação Especial, 5., 2012, São Carlos. Anais... São Carlos: UFSCar, 2012. p. 2933-2947. 1 CD ROM.

MILNER, A. Estudos culturais. In: WILLIAMS, R. Palavras-chave: um vocabulário de cultura e sociedade. São Paulo: Boitempo, 2007. p. 420-427. 
MOREIRA, S. Z. A mulher surda e suas relações de gênero e sexualidade. In: SKLIAR, C. (Org.). A surdez: um olhar sobre as diferenças. 3. ed. Porto Alegre: Mediação, 2005b. p. 95103.

NELSON, C.; TREICHLER, P. A.; GROSSBERG, L. Estudos Culturais: uma introdução. In: SILVA, T. T. da. (Org.). Alienígenas na sala de aula. 8. ed. Petrópolis, RJ: Vozes, 2009. p. 7- 38.

NORA, P. Entre memória e história: a problemática dos lugares. Projeto História, São Paulo, n.10, p. 07-28, dez.1993.

PAULA, M. de F. de. O processo de modernização da universidade - casos USP e UFRJ. Tempo Social, Revista de Sociologia da USP, São Paulo, v. 12, n. 2, p. 189-202, nov. 2000. Disponível em: <http://www.revistas.usp.br/ts/article/view/12341>. Acesso em: 08 abr. 2013.

PEREIRA, T. de L. Os desafios da implementação do ensino de Libras no ensino superior. 2008. 94 f. Dissertação (Mestrado em Educação). Centro Universitário Moura Lacerda, Ribeirão Preto, 2008. Disponível em:

http://www.dominiopublico.gov.br/pesquisa/DetalheObraForm.do? select_action=\&co_obra=1 30207>. Acesso em 14 mar. 2011.

PEREIRA, M. C. da C. et al. LIBRAS: conhecimento além dos sinais. São Paulo: Pearson Prentice Hall, 2011.

PERLIN, G. T. T. O lugar da cultura surda. In: THOMA, A. da S.; LOPES, M. C. (Orgs.). A invenção da surdez: cultura, alteridade, identidades e diferença no campo da educação. Santa Cruz do Sul: EDUNISC, 2004. p. 73-82.

Identidades surdas. In: SKLIAR, C. (Org.). A surdez: um olhar sobre as diferenças. 3. ed. Porto Alegre: Mediação, 2005. p. 51-73.

A cultura surda e os intérpretes de Língua de Sinais (ILS). ETD - Educação

Temática Digital, Campinas, SP, v. 7, n. 2, p. 136-147, jun. 2006. Disponível em: $<$ http://www.fae.unicamp.br/revista/index.php/etd/article/view/1636/1484>. Acesso em: 8 abr. 2013.

POLLAK, M. Memória e identidade social. Estudos históricos, Rio de Janeiro, v. 5, n.10, p. 200-212, 1992.

QUADROS, R. M. de. Educação de surdos: a aquisição da linguagem. Porto Alegre: Artes 
Médicas, 1997.

QUADROS, R. M. de; KARNOPP, L. B. Língua de Sinais Brasileira: estudos linguísticos. Porto Alegre: Artmed, 2004.

QUADROS, R. M. de. O "BI" em bilinguismo na educação de surdos. In: FERNANDES, E. (Org.). Surdez e bilinguismo. Porto Alegre: Mediação, 2005. p. 26-36.

QUADROS, R. M. de; et al. Exame Prolibras. Florianópolis, 2009. Disponível: http: www.prolibras.ufsc.br/livro_prolibras.pdf> Acesso em: 13 de fev. 2013.

RANGEL, G. M. M.; STUMPF, M. R. A pedagogia da diferença para o surdo. In: LODI, A. C. B.; MÉLO, A. D. B. de; FERNANDES, E. (Orgs.). Letramento, bilinguismo e educação de surdos. Porto Alegre: Mediação, 2012. p. 113-124.

REBOUÇAS, L. S. A prioridade de docentes surdos para ensinar a disciplina língua brasileira de sinais (LIBRAS) nas instituições de ensino superior após decreto 5.626/2005. 175 f. 2009. Dissertação (Mestrado) - Faculdade de Educação, Universidade Federal da Bahia, Salvador, 2009. Disponível em:

http://editora-arara-azul.com.br/portal/media/k2/attachments/volume7.pdf > Acesso em: 30 de mar. 2013.

REVEL, J. Michel Foucault: conceitos essenciais. São Paulo: Claraluz, 2005.

REZENDE, P. L. F. Implante coclear: normalização e resistência surda. Curitiba: CRV, 2012.

RÍOS, A. Los estúdios culturales y el estudio de la cultura em América Latina. In: Estudios y otras prácticas intelectuales latinoamericanas en cultura y poder. MATO, D. (Org.). CLACSO, Consejo Latinoamericano de Ciencias Sociales: Caracas, 2002. Disponível em: http://bibliotecavirtual.clacso.org.ar/ar/libras/cultura/rios.doc.> Acesso em 13 de mai. 2012.

ROSA, A. da S. A presença do intérprete de Língua de Sinais na mediação social entre surdos e ouvintes. In: SILVA, I. R.; KAUCHAKJE, S.; GESUELI, Z. M. (Orgs.). Cidadania, surdez e linguagem: desafios e realidades. São Paulo: Plexus, 2003. p. 235-243.

SÁ, N. R. L. de. Cultura, poder e educação de surdos. Manaus: Editora da Universidade Federal do Amazonas, 2002. 
Discurso surdo: a escuta dos sinais. In: SKLIAR, C. (Org.). A surdez: um olhar sobre as diferenças. 3. ed. Porto Alegre: Mediação, 2005. p. 169-192.

SACKS, O. Vendo vozes: uma viagem ao mundo dos surdos. São Paulo: Companhia das Letras, 1998.

SANTANA, A. P. Surdez e linguagem: aspectos e implicações neurolinguísticas. São Paulo: Plexus, 2007.

SANTOMÉ, F. T. As culturas negadas e silenciadas no currículo. In: SILVA, T. T. da. (Org.). Alienígenas na sala de aula. 11. ed. Petrópolis, RJ: Vozes, 2013. p. 155-172.

SANTOS, M. F. C. dos; LIMA, M. C. M. P.; ROSSI, T. R. de F. Surdez: diagnóstico audiológico. In: SILVA, I. R.; KAUCHAKJE, S.; GESUELI, Z. M. (Orgs.). Cidadania, surdez e linguagem: desafios e realidades. São Paulo: Plexus, 2003. p. 17-40.

SÃO PAULO. Decreto $\mathbf{n}^{0}$ 52.785, de 10 de novembro de 2011. Cria as Escolas Municipais de Educação Bilíngue para Surdos - EMEBS na Rede Municipal. São Paulo-SP, 2011. Disponível em:

$<$ http://dobuscadireta.imprensaoficial.com.br/default.aspx?DataPublicacao=20111111\&Cader no=DOC\&NumeroPagina=1> Acesso em: 20 jan. 2012.

SCHAADE, S. Um ano de Libras! Saldos e balanços. [Blog]. São Paulo, 18 ago. 2013 Disponível em: <http://filhosespeciaispaisabencoados.blogspot.com.br/2013/08/um-ano-delibras-saldos-e-balancos.html> Acesso em: 08 jun. 2014.

SILVA, R. C. L.; ARAÚJO, S. G. Os resultados do implante coclear em crianças portadoras de Neuropatia Auditiva: revisão de literatura. Revista da sociedade brasileira de fonoaudiologia, São Paulo, v. 12 n. 3, p. 252-257, jul/set. 2007. Disponível em: ‘http://www.scielo.br/scielo.php?pid=S1516-80342007000300014\&script=sci_arttext $>$ Acesso em: 08 jun. 2014.

SILVA, C. A. de A. Cultura surda: agentes religiosos e a construção de uma identidade. São Paulo: Terceiro Nome, 2012.

SILVA, T. T. da. A produção social da identidade e da diferença. In: SILVA, T. T. da (Org.); HALL, S.; WOODWARD, K. Identidade e diferença: a perspectiva dos estudos culturais. 12. ed. Petrópolis, RJ: Vozes, 2012. p. 73-102. 
SILVEIRA, R. M. H.; SILVEIRA, C. H.; BONIN, I. T. Literatura infantil no século XXI: surdez e personagens surdos. In: KARNOPP, L. B.; KLEIN, M.; LUNARDI-LAZZARIN, M. L. (Orgs.). Cultura surda na contemporaneidade: negociações, intercorrências e provocações. Canoas: Ed. ULBRA, 2011. p. 191-203.

SINEDINO, R. Entrevista. In: LOBATO, L. Fala Raul. [Blog]. São Paulo, 06 mai. 2009. Disponível em: <http://desculpenaoouvi.laklobato.com/2009/05/06/falaraul/> Acesso em: 07 jun. 2014.

SKLIAR, C . Uma perspectiva sócio-antropológica sobre a psicologia e a educação de surdos. In: SKLIAR, C. (Org.). Educaçãa e exclusão: abordagens sócio-antropológicas em educação especial. 4. ed. Porto Alegre: Mediação, 2004. p.75-110.

Um olhar sobre o nosso olhar acerca da surdez e as diferenças. In: SKLIAR, C.

(Org.). A surdez: um olhar sobre as diferenças. 3. ed. Porto Alegre: Mediação, 2005a. p. 5-6.

Os estudos surdos em educação: problematizando a normalidade. In: SKLIAR, C.

(Org.). A surdez: um olhar sobre as diferenças. 3. ed. Porto Alegre: Mediação, 2005b. p. 732.

A localização política da educação bilíngue para surdos. In: SKLIAR, C. (Org.). Atualidades da educação bilíngue para surdos. 3. ed. Porto Alegre: Mediação, 2009. v. 1. p. 7-14.

SOUZA, R. M. de. Língua de sinais e escola: considerações a partir do texto de regulamentação da língua brasileira de sinais. ETD - Educação Temática Digital, Campinas, SP, v. 7, n. 2, p. 266-281, jun. 2006. Disponível em: <http://www.fae.unicamp.br/revista/index.php/etd/article/view/1647/1494>. Acesso em: 8 abr. 2013.

STROBEL, K. As imagens do outro sobre a cultura surda. Florianópolis: Editora da UFSC, 2008.

STUMPF, M. R. Sistema SIGNWRITING: por uma escrita funcional para o surdo. In: THOMA, A. da S.; LOPES, M. C. (Orgs.). A invenção da surdez: cultura, alteridade, identidades e diferença no campo da educação. Santa Cruz do Sul: EDUNISC, 2004. p. 143159.

SVARTHOLM, K. Bilinguismo dos surdos. In: SKLIAR, C. (Org.). Atualidades da educação bilíngue para surdos. 3. ed. Porto Alegre: Mediação, 2009. v.2. p. 15-23. 
TAJFEL, H. Grupos humanos e categorias sociais: estudos em psicologia social. Lisboa: Livros horizonte, 1983. v. 2.

TESKE, O. A relação dialógica como pressuposto na aceitação das diferenças: o processo de formação das comunidades surdas. In: SKLIAR, C. (Org.). A surdez: um olhar sobre as diferenças. 3. ed. Porto Alegre: Mediação, 2005. p. 139-156.

THOMA, A. da S. A inversão epistemológica da anormalidade surda na pedagogia do cinema. In: THOMA, A. da S.; LOPES, M. C. (Orgs.). A invenção da surdez: cultura, alteridade, identidades e diferença no campo da educação. Santa Cruz do Sul: EDUNISC, 2004. p. 56-69.

Surdo: esse "outro" de que fala a mídia. In: SKLIAR, C. (Org.). A surdez: um olhar sobre as diferenças. 3. ed. Porto Alegre: Mediação, 2005. p. 123-138.

VEIGA-NETO, A. Michel Foucault e os Estudos Culturais. In: COSTA, M.V. (Org.).

Estudos culturais em educação: mídia, arquitetura, brinquedo, biologia, literatura, cinema. Porto Alegre: Ed. Universidade/UFRGS, 2000. p. 37-69.

Incluir para excluir. In: LARROSA, J.; SKLIAR, C. (Orgs.). Habitantes de Babel: políticas e poéticas da diferença. Belo Horizonte: Autêntica, 2001. p. 105-118.

VERGAMINI, S. A. A. (Org.). Mãos fazendo história. Petrópolis, RJ: Editora Arara Azul, 2003.

VILHALVA, S. Índios surdos: mapeamento das línguas de sinais do Mato Grosso do Sul. Petropólis: Arara Azul, 2012.

VITALIANO, C. R.; et al. Análises dos currículos dos cursos de pedagogia das universidades públicas dos estados do Paraná e de São Paulo em relação à formação para inclusão de alunos com Necessidades Educacionais Especiais. Revista Eletrônica Pró-docência. UEL. v. 1, n. 1 jan-jun. 2012. Disponível em:

<http: www.uel.br/revistas/prodocenciafope>. Acesso em: 30 de mar. de 2013.

WILCOX, S.; WILCOX, P. P. Aprender a ver: o ensino da língua de sinais americana como segunda língua. Petrópolis: Arara Azul, 2005. Disponível em:

<http://www.editora-arara-azul.com.br/pdf/livro2.pdf>. Acesso em: 13 fev. 2013.

WILLIAMS, R. Palavras-chave: um vocabulário de cultura e sociedade. São Paulo: Boitempo, 2007. 
Cultura e sociedade: de Coleridge a Orwel. Petrópolis, RJ: Vozes, 2011.

WOODWARD, K. Identidade e diferença: uma introdução teórica conceitual. In: SILVA, T. T. da (Org.) Identidade e diferença: a perspectiva dos estudos culturais. 9.ed. Petrópolis, RJ: Vozes, 2009. p. 07-72. 
APÊNDICES 


\section{APÊNDICE A}

Modelo de ofício enviado aos coordenadores dos cursos de licenciatura

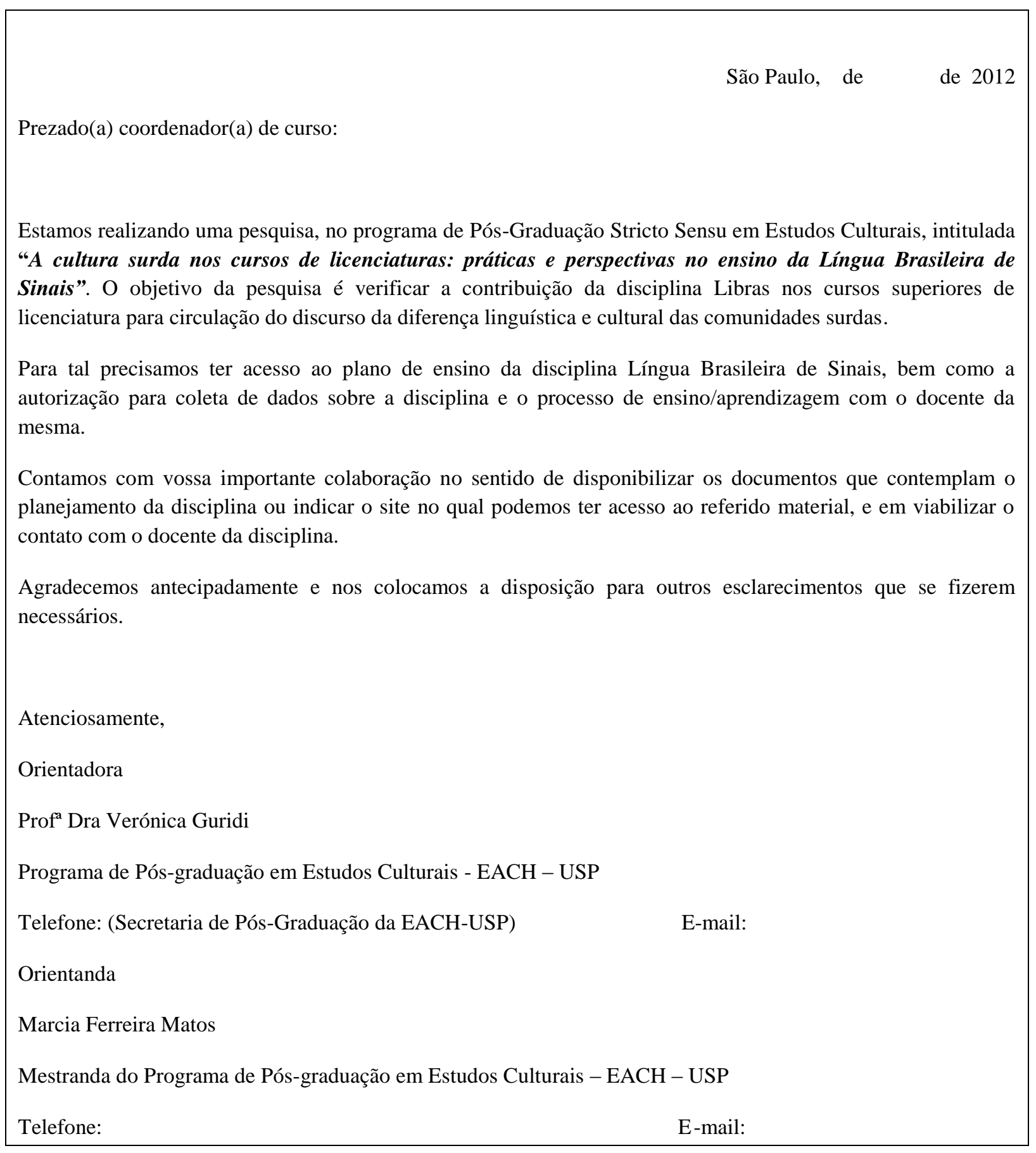




\section{APÊNDICE B}

Modelo de carta de esclarecimento dirigida aos docentes

Caro(a) docente da disciplina Língua Brasileira de Sinais,

Estamos desenvolvendo uma pesquisa intitulada "A cultura surda nos cursos de licenciatura: práticas $e$ perspectivas no ensino da Língua Brasileira de Sinais” no Programa de Pós-graduação em Estudos Culturais da Escola de Artes, Ciências e Humanidades - EACH da Universidade de São Paulo - USP. E o intuito do trabalho é verificar a contribuição da disciplina Libras nos cursos superiores de licenciatura para circulação do discurso da diferença linguística e cultural das comunidades surdas.

Para tanto estamos coletando alguns dados que têm como foco o perfil e a prática pedagógica de docentes da disciplina Língua Brasileira de Sinais em Instituições de Ensino Superior que já tenham incluído a mesma nas grades curriculares dos cursos de licenciatura.

Em anexo segue um breve questionário e contamos com vossa importante colaboração em respondê-lo e reenviá-lo, até o dia de 2012, para o e-mail:

A coleta e utilização de registros do questionário ou de textos/documentos ocorrerão como dados para fins, exclusivamente, acadêmicos para a elaboração de produtos de pesquisa visando a publicação de artigos científicos e/ou apresentações em congressos, bem como a elaboração da Dissertação de Mestrado.

As responsáveis pela pesquisa garantem o sigilo que assegure a privacidade dos sujeitos quanto aos dados envolvidos nos trabalhos acadêmico-científicos de acordo com a ética na pesquisa. E, a participação dos sujeitos não comporta qualquer remuneração.

Desde já agradecemos sua colaboração e o tempo despendido e nos colocamos a disposição, para outros esclarecimentos que se fizerem necessários.

Tão logo tenha os resultados da pesquisa teremos grande satisfação em disponibilizá-los aos interessados.

Atenciosamente,

\section{Marcia Ferreira Matos}

Mestranda em Estudos Culturais - EACH -USP

Telefone:

E-mail:

\section{Orientadora Prof ${ }^{a}$ Dra Verónica Guridi}

Telefone: (Secretaria de Pós-Graduação da EACH-USP) E-mail: 


\section{APÊNDICE C}

Modelo de questionário enviado aos docentes das IES

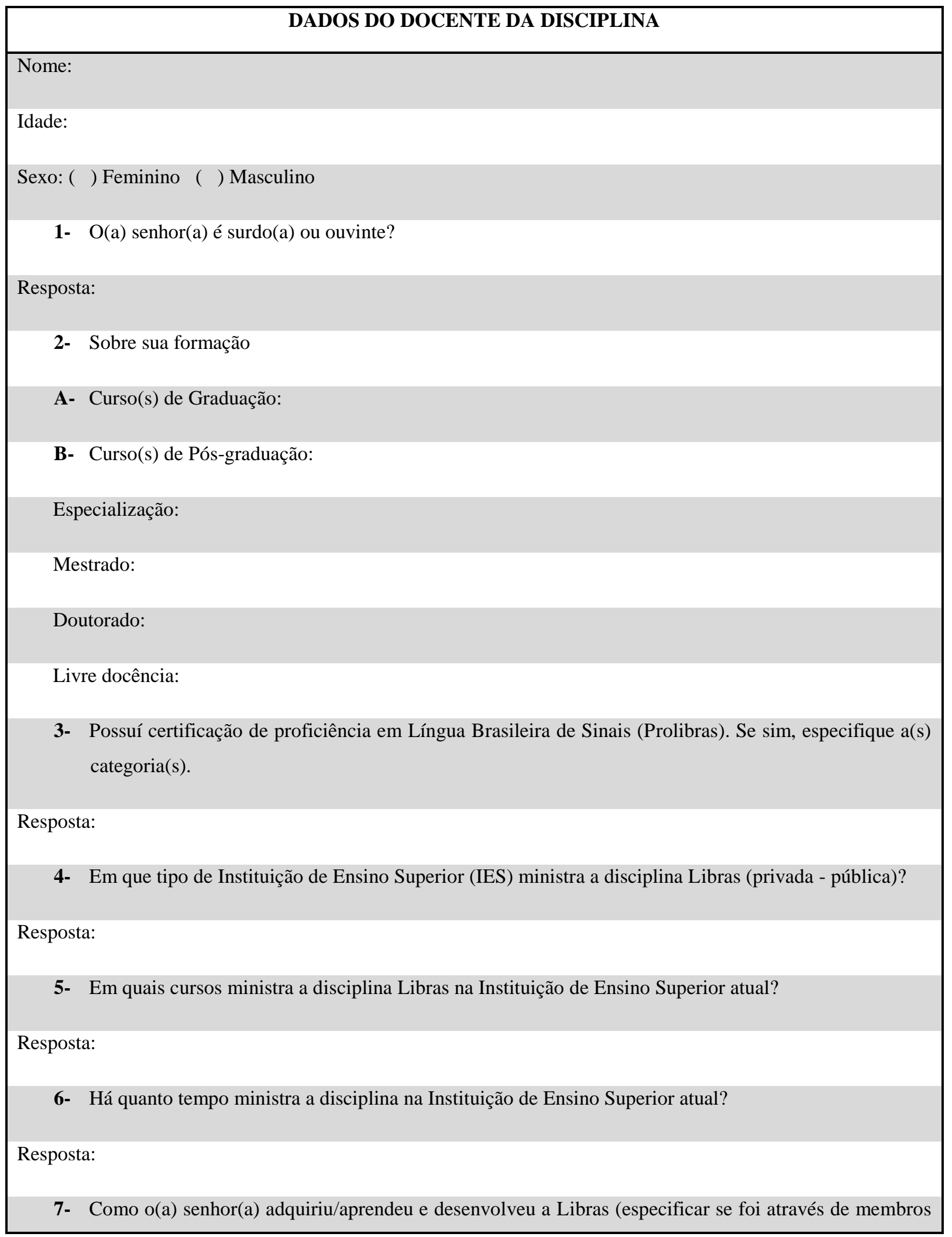




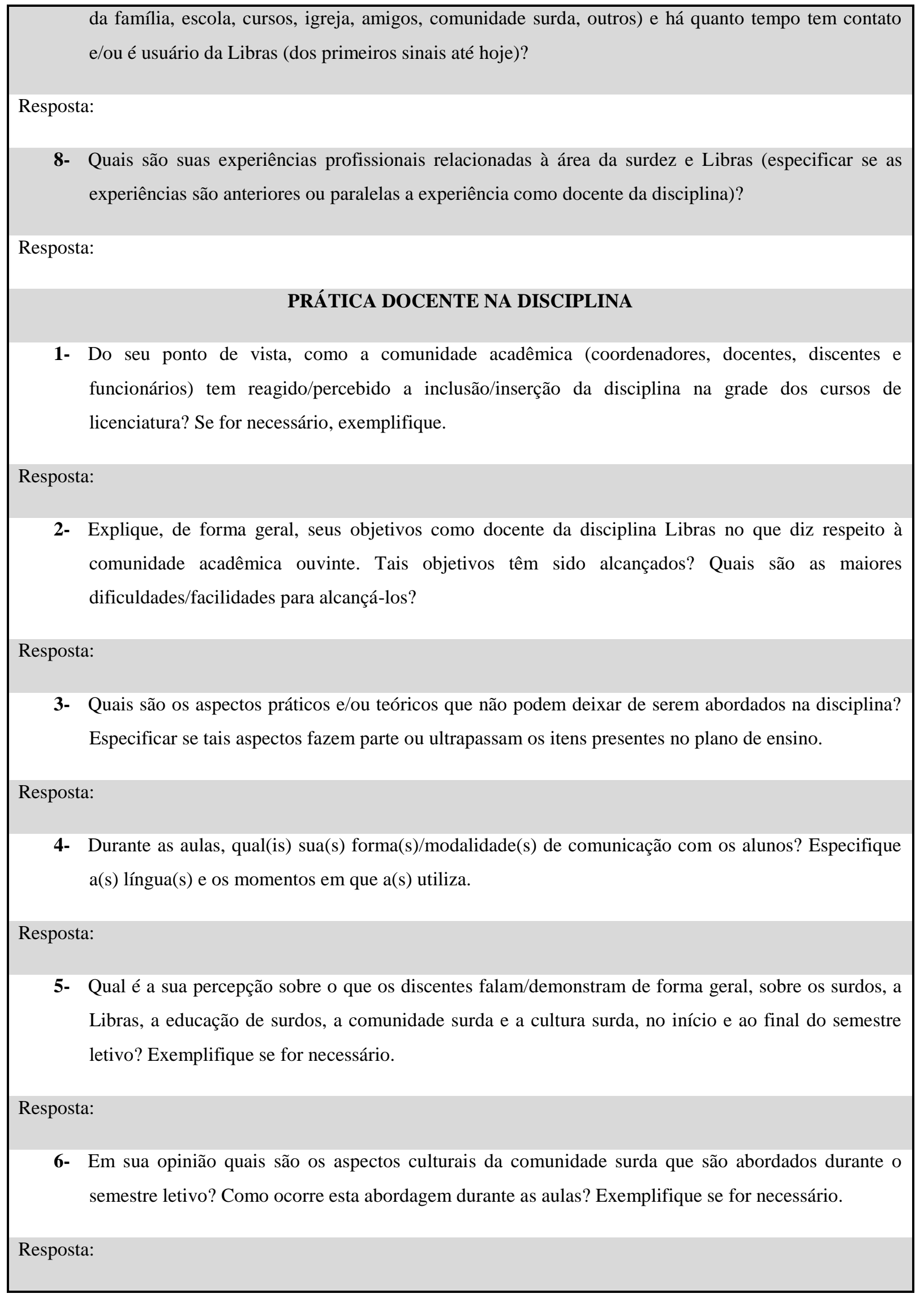




\section{APÊNDICE D}

Modelo do termo de consentimento da coleta de dados por meio de áudio e/ou vídeo

São Paulo, de de 2012 .

\section{TERMO DE CONSENTIMENTO LIVRE E ESCLARECIDO}

$\mathrm{Eu}$

RG concordo em participar das atividades de pesquisa decorrentes do projeto de Mestrado "A Cultura Surda nos Cursos de Licenciatura: práticas e perspectivas no ensino da Língua Brasileira de Sinais" da aluna Marcia Ferreira Matos, ${ }^{\circ}$ USP , orientada pela profa. Dra. Verónica Marcela Guridi no marco do Programa de Pós-Graduação em Estudos Culturais da Escola de Artes, Ciências e Humanidades EACH da Universidade de São Paulo.

O presente trabalho acadêmico tem como finalidade verificar a contribuição da disciplina Libras nos cursos superiores de licenciatura para circulação do discurso da diferença linguística e cultural das comunidades surdas.

Declaro consentir o registro de falas em Língua Portuguesa e/ou em Língua Brasileira de Sinais na forma de gravação em áudio e/ou em vídeo, para fins, exclusivamente, acadêmicos para a elaboração de produtos de pesquisa visando à publicação de artigos científicos e/ou apresentações em congressos, bem como à elaboração da Dissertação de Mestrado.

Compreendo que tenho a liberdade de retirar o meu consentimento em qualquer fase da elaboração dos trabalhos acadêmicos, sem penalização alguma. A qualquer momento posso buscar maiores esclarecimentos, inclusive relativos à metodologia do trabalho através dos endereços eletrônicos: . As responsáveis pela pesquisa garantem o sigilo que assegure a privacidade dos sujeitos quanto aos dados envolvidos nos trabalhos acadêmico-científicos de acordo com a ética na pesquisa. Compreendo, ainda, que esta participação não comporta qualquer remuneração.

Assinatura do voluntário(a) da pesquisa

Assinatura da $\operatorname{Prof}^{\mathrm{a}}$. Dr ${ }^{\mathrm{a}}$ responsável

Assinatura da pesquisadora 


\begin{abstract}
APÊNDICE E
Transcrição dos enunciados dos docentes e dados dos planos de ensino da disciplina Libras utilizados na análise do capítulo "A cultura surda nos cursos de licenciatura: práticas e perspectivas no ensino da Língua Brasileira de Sinais"
\end{abstract}

\begin{tabular}{|c|c|}
\hline \multicolumn{2}{|r|}{ A institucionalização da disciplina Libras nas IES } \\
\hline Ana & $\begin{array}{l}\text { "A comunidade acadêmica de forma geral recebeu bem a disciplina e os alunos } \\
\text { mostram interesse, principalmente se a mesma está inserida no início do curso. } \\
\text { No entanto, ela ainda é tratada com superficialidade, dadas as condições de } \\
\text { ensino (falta de materiais, turmas grandes, etc)". }\end{array}$ \\
\hline Bruno & $\begin{array}{l}\text { "Percebo que esse despertar foi apenas por força de lei. Antes da lei, não havia } \\
\text { preocupação com a inclusão do aluno surdo, que dirá a inserção de uma } \\
\text { disciplina que falasse sobre Libras e sobre Surdez. Mas percebi também que } \\
\text { após a lei, as instituições perceberam que era um processo importante, que } \\
\text { poderia contribuir com a formação dos alunos. A [citou a IES pesquisada], por } \\
\text { exemplo, criou o Programa de Difusão de Libras, para que funcionários e } \\
\text { professores tenham contato com a Libras. Começou com uma imposição da } \\
\text { legislação, mas em seguida houve uma boa aceitação e muitas instituições } \\
\text { foram além do que simplesmente cumprir a lei". }\end{array}$ \\
\hline Carla & $\begin{array}{l}\text { "Se constitui em um grande desafio principalmente nas licenciaturas (com } \\
\text { exceção da Pedagogia) iniciando-se pelas atitudes do corpo docente em relação } \\
\text { à atuação do professor de Libras. Iniciei as atividades na Universidade [...] } \\
\text { provisoriamente [...] nos cursos de Filosofia, Ciências Sociais e História para } \\
\text { atender a demanda de licenciandos que se formariam em } 2010 \text { e, nesse início, o } \\
\text { acolhimento não foi sentido por mim, tendo em vista as resistências de } \\
\text { profissionais desses cursos na contratação de um professor de Libras. Embora } \\
\text { a presença do professor de Libras seja uma exigência legal, além do } \\
\text { desconhecimento dessa exigência, teve uma resistência com a argumentação de } \\
\text { que os departamentos não dispunham de vagas para tal profissional, } \\
\text { intensificando-se a discussão: em qual departamento o segundo profissional de }\end{array}$ \\
\hline
\end{tabular}




\begin{tabular}{|c|c|}
\hline & $\begin{array}{l}\text { Libras (esse ministraria aulas nas licenciaturas em geral) se vincularia no } \\
\text { Campus [citou um dos campi da IES pesquisada]? Diante dessa lacuna, } \\
\text { atualmente há um segundo professor contratado para atuar por um ano nas } \\
\text { licenciaturas do referido campus. Recentemente, foi aprovada a realização de } \\
\text { um concurso para o ingresso de dois professores de Libras que atuarão nas } \\
\text { licenciaturas [...]. Atualmente, atuo apenas no curso de Pedagogia. Meu } \\
\text { ingresso no referido curso foi tranquilo, sendo inclusive profissionais } \\
\text { vinculados a esse curso que têm defendido a inserção da disciplina de Libras } \\
\text { em todos os cursos de licenciaturas, questão essa que parece resolvida } \\
\text { atualmente no campus". }\end{array}$ \\
\hline Daniela & $\begin{array}{l}\text { "Aqui na [citou a IES pesquisada] isso tudo é muito novo, faz dois meses que } \\
\text { isso está funcionando. A receptividade foi muito boa, interessante. Houve uma } \\
\text { dificuldade para encontrar o profissional [...] com o perfil para ministrar a } \\
\text { disciplina. [Sobre o perfil exigido] professor doutor que tivesse experiência na } \\
\text { área, que tivesse fluência em Libras, que tivesse uma trajetória acadêmica um } \\
\text { pouco mais consolidada. O concurso é muito exigente [...]. Eles estabeleceram } \\
\text { um perfil, e por conta disso, eles tinham feito quatro concursos, [...] este } \\
\text { concurso que eu prestei era o quinto, então a expectativa era grande tanto por } \\
\text { parte dos alunos quanto por parte dos docentes, de todo mundo [...]. Os } \\
\text { professores estavam muito curiosos para saber quem ia dar libras. [...] A } \\
\text { educação especial aqui já tem, já existe, mas a disciplina de Libras é nova, } \\
\text { então havia também por parte dos funcionários uma expectativa”. }\end{array}$ \\
\hline Emília & $\begin{array}{l}\text { “[...] já tive o contato com a coordenação de um curso de licenciatura que não } \\
\text { ministro aulas, mas que tem a disciplina Libras incluída na grade curricular há } \\
\text { mais de um ano letivo, bem como com a docente que ministra a referida } \\
\text { disciplina nesse mesmo curso. O contato com a docente de Libras do curso de } \\
\text { Pedagogia ocorreu de modo assistemático no primeiro semestre, para que } \\
\text { pudéssemos organizar um projeto de extensão dirigido aos alunos do Campus, } \\
\text { para o ano de 2013. No segundo semestre, iniciadas as atividades da } \\
\text { Universidade, iniciamos o projeto de extensão, assim como as aulas. No } \\
\text { entanto, até o momento, nenhum dos coordenadores dos cursos para os quais a } \\
\text { disciplina é dirigida me procurou, não tomei esta iniciativa por não ter claro a }\end{array}$ \\
\hline
\end{tabular}




\begin{tabular}{|c|c|}
\hline & $\begin{array}{l}\text { quem me dirigir. Percebo que existe uma preocupação da existência ou não das } \\
\text { aulas, mas não da qualidade delas, da parte destes coordenadores. [...] } \\
\text { o contato com os discentes que tem a disciplina tem ocorrido através das aulas } \\
\text { semanais e foi extremamente proveitoso, os discentes são interessados, } \\
\text { produtivos e ativos durante as aulas. [...] E com os funcionários o contato é } \\
\text { bastante cordial e interessado". }\end{array}$ \\
\hline Flávia & $\begin{array}{l}\text { "Creio que a reação é positiva, apesar de as pessoas dizerem que tem muita } \\
\text { dificuldade em conseguir realizar os sinais. A [citou a IES pesquisada] } \\
\text { promoveu recentemente um curso de algumas horas para os funcionários da } \\
\text { secretaria de Libras. Penso que essa questão mostra que as pessoas têm muito } \\
\text { desejo de aprender". }\end{array}$ \\
\hline & Práticas pedagógicas \\
\hline Ana & $\begin{array}{l}\text { - Plano de Ensino - Objetivos gerais e específicos: } \\
\text { Definir e conceituar linguagem, língua, fala e surdez. Conhecer as filosofias } \\
\text { educacionais para surdos: Oralismo, Comunicação Total e Bilinguismo. } \\
\text { Introduzir o ouvinte à Língua Brasileira de Sinais-Libras e às modalidades } \\
\text { diferenciadas para a comunicação gestual-visual. Criar oportunidades para a } \\
\text { prática de Língua Brasileira de Sinais. Ampliar conhecimento dos aspectos } \\
\text { culturais do mundo surdo. Desenvolver competências que favoreçam ao } \\
\text { licenciado assumir seu papel de facilitador e promotor de processos inclusivos } \\
\text { no âmbito educacional. } \\
\text { - Objetivos da docente com relação à disciplina: } \\
\text { "Meu maior objetivo é que os alunos rompam preconceitos em relação às } \\
\text { deficiências e tenham um primeiro contato positivo com a língua, abrindo } \\
\text { caminho para um possível aprofundamento futuro. Acredito que este objetivo } \\
\text { esteja sendo alcançado, apesar das dificuldades citadas anteriormente. [a } \\
\text { docente se referia ao seguinte trecho: ela ainda é tratada com superficialidade, } \\
\text { dada as condições de ensino (falta de materiais, turmas grandes, etc)]”. }\end{array}$ \\
\hline
\end{tabular}




\begin{tabular}{|c|c|}
\hline Bruno & 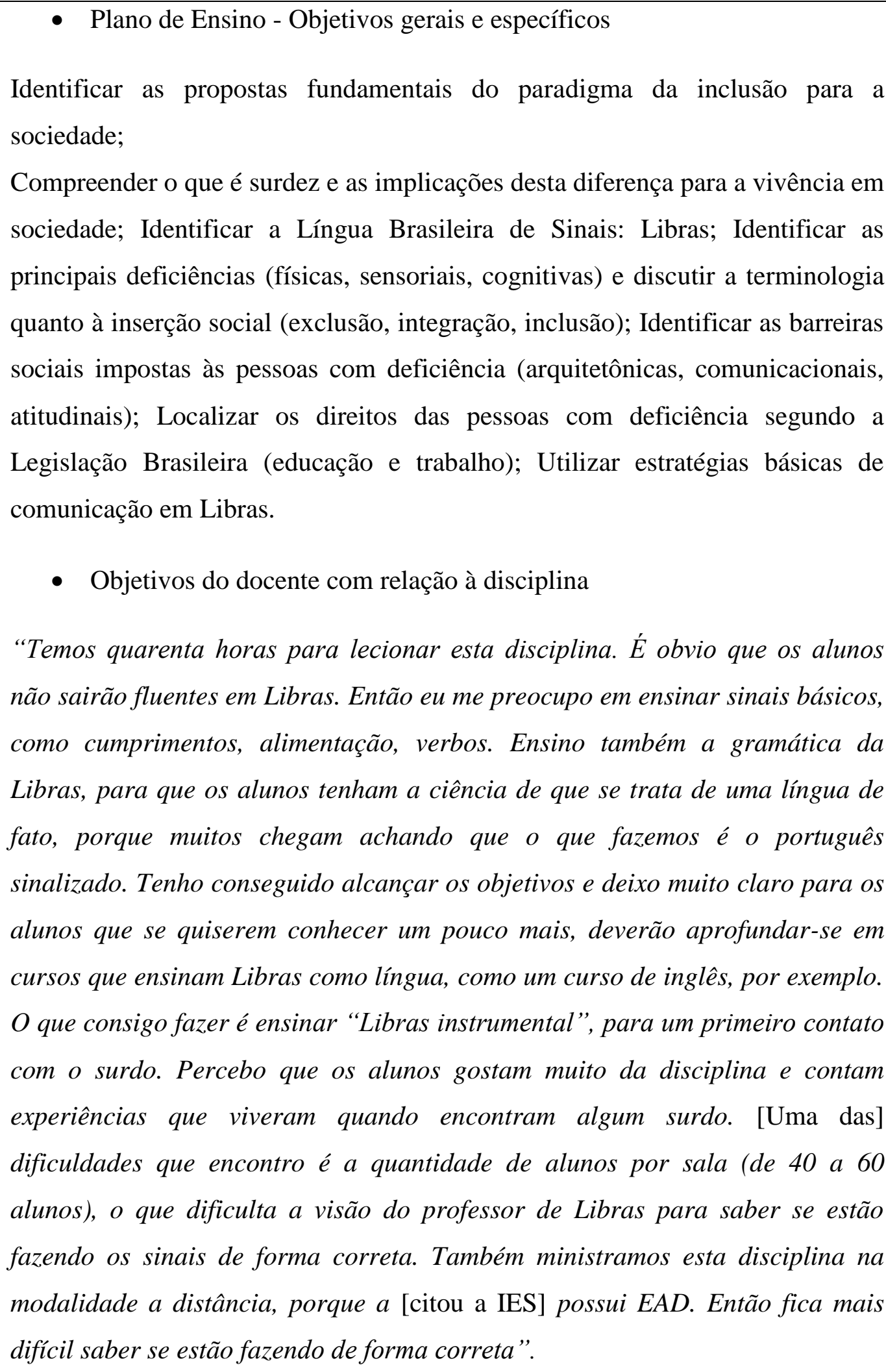 \\
\hline Carla & $\begin{array}{l}\text { - Plano de Ensino - Objetivos gerais e específicos } \\
\text { Conhecer as políticas educacionais que tratam dos direitos linguísticos e } \\
\text { inclusão social do surdo e refletir sobre o contexto educacional e a efetividade }\end{array}$ \\
\hline
\end{tabular}




\begin{tabular}{|c|c|}
\hline & 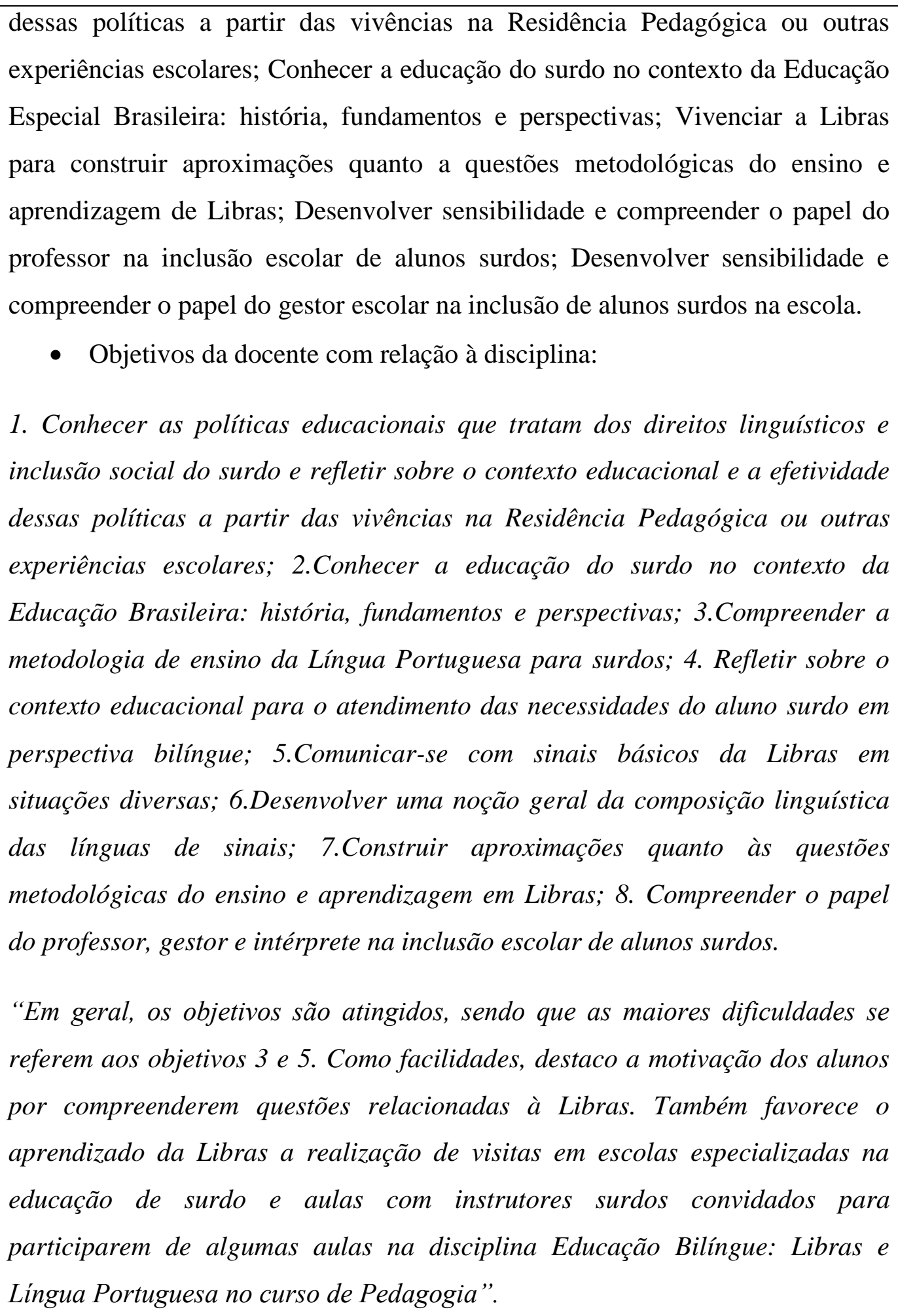 \\
\hline D & $\begin{array}{l}\text { - Plano de Ensino - Objetivos gerais e específicos } \\
\text { Contribuir para o aprimoramento da formação dos alunos para a atuação direta e } \\
\text { indireta junto à comunidade surda; Possibilitar a compreensão, reflexão e } \\
\text { aprendizado da Língua Brasileira de Sinais - Libras, numa perspectiva histórica, }\end{array}$ \\
\hline
\end{tabular}




\begin{tabular}{|c|c|}
\hline & $\begin{array}{l}\text { social, cultural, educacional e linguística; Favorecer o acesso ao conhecimento } \\
\text { da cultura/identidade surda; Educação Bilíngue e aspectos gramaticais da Libras } \\
\text { e sua aplicação na interpretação; Oferecer oportunidade de reflexões a partir do } \\
\text { processo de escolarização e inclusão social entre pessoas surdas e ouvintes; } \\
\text { Operacionalizar práticas e atividades educacionais que contemplem o } \\
\text { atendimento à diversidade dos alunos no cotidiano escolar. } \\
\text { - Objetivos da docente com relação à disciplina } \\
\text { "[...] A gente sabe que o ensino de uma língua, principalmente a Libras, não se } \\
\text { dá em } 60 h \text {, a língua a gente precisa estar estudando, se aperfeiçoando e ter } \\
\text { contato com usuários. Meu objetivo maior com essa disciplina é fazer com que } \\
\text { os alunos tenham contato com a língua, e que tenham um aprendizado que eu } \\
\text { chamo de básico. A gente adotou um dicionário de apoio e a intenção é que, } \\
\text { primeiro, eles conheçam a língua, conheçam as características gramaticais da } \\
\text { língua, além de todo esse referencial teórico paralelo sobre surdez. Que [...] } \\
\text { conheçam a estrutura gramatical da língua de sinais e passem a utilizar a } \\
\text { língua de sinais na sala de aula. Que [...] entendam quem é o aluno surdo que } \\
\text { está ali, que eles saibam organizar o trabalho, a partir das características } \\
\text { daquele aluno usando a língua de sinais. [...] Mesmo trabalhando de forma } \\
\text { muito sistemática, muito pontual dos conteúdos que eu elaborei, eles vão } \\
\text { precisar de um aperfeiçoamento depois, porque não dá para aprender um } \\
\text { idioma em } 60 \text { h [...], eles estão começando a perceber que terão que estudar } \\
\text { cada vez mais, como qualquer língua [...]”. }\end{array}$ \\
\hline En & $\begin{array}{l}\text { - Plano de Ensino - Objetivos gerais e específicos } \\
\text { Levar os alunos a conhecer e usar estruturas básicas da Libras, conhecendo a } \\
\text { língua e a especificidade de funcionamento social da Comunidade Surda; Levar } \\
\text { os alunos a compreenderem os aspectos sócio-históricos que permitem o } \\
\text { entendimento do contexto atual da Comunidade Surda; Compreender a língua } \\
\text { de sinais como fator aglutinador da Comunidade Surda; Possibilitar aos alunos } \\
\text { os primeiros contatos com a Libras, apresentando suas especificidades } \\
\text { gramaticais. }\end{array}$ \\
\hline
\end{tabular}




\begin{tabular}{|c|c|}
\hline & $\begin{array}{l}\text { - Objetivos da docente com relação à disciplina } \\
\text { "O objetivo mais geral é que os alunos tenham contato com a língua de sinais, } \\
\text { primeiramente sabendo da existência dela, e possam saber da importância } \\
\text { dessa língua para os surdos. Promovendo ou incentivando que eles tenham } \\
\text { contato com a comunidade surda, não somente para conhecer a língua, mas } \\
\text { para compreender o seu funcionamento e importância para esse grupo”. } \\
\text { "Neste momento a maior dificuldade foi o tempo, pois com o prazo encurtado } \\
\text { para as aulas, algumas propostas tiveram de ser enxugadas, para caber no } \\
\text { cronograma, de outra forma os alunos foram extremamente receptivos e } \\
\text { envolvidos". }\end{array}$ \\
\hline Flávia & $\begin{array}{l}\text { • Plano de Ensino - Objetivos gerais e específicos } \\
\text { Refletir acerca das diferenças entre a Língua Brasileira de Sinais e o Português; } \\
\text { Entender a importância do ensino da Língua Brasileira de Sinais - Libras como } \\
\text { primeira língua para sujeitos surdos; Conhecer e respeitar a diferença linguística } \\
\text { entre o surdo e o ouvinte; Capacitar os futuros educadores no conhecimento da } \\
\text { Língua Brasileira de Sinais - Libras. } \\
\text { - Objetivos da docente com relação à disciplina } \\
\text { “O primeiro objetivo é desmistificar a questão da surdez ligada a 'mudez'. Em } \\
\text { segundo lugar é promover o conhecimento da comunidade surda como sendo } \\
\text { uma comunidade que tem possibilidades de aprendizagem no ensino } \\
\text { fundamental e médio, porém necessitam de uma língua específica e de uma } \\
\text { organização pedagógica com recursos visuais para poderem aprender. Tento } \\
\text { aprofundar o conhecimento dos sinais por meio de histórias e de apresentações } \\
\text { dos alunos com pequenos diálogos”. }\end{array}$ \\
\hline Ana & $\begin{array}{l}\text { - Principais conteúdos apontados pela docente. } \\
\text { "Primeiramente, tratar a respeito da recente formalização da língua, o que } \\
\text { implica em uma profusão de sinais divergentes e, por vezes não registrados em } \\
\text { dicionários. É preciso abordar a questão para que o aluno ouvinte não se sinta } \\
\text { inseguro em relação ao aprendizado. Também é necessário abordar sobre } \\
\text { aspectos práticos, tais como os aspectos que constituem os sinais (configuração }\end{array}$ \\
\hline
\end{tabular}




\begin{tabular}{|c|c|}
\hline & $\begin{array}{l}\text { de mão, movimento, etc), e por fim a cultura surda como objeto de estudo para } \\
\text { a educação. Estes pontos estão, de alguma forma, previstos no plano de ensino } \\
\text { [...]. Durante as aulas eles desenvolvem o conteúdo elaborando diálogos em } \\
\text { grupos". } \\
\text { • Modalidades linguísticas, estratégias e exercícios propostos. } \\
\text { "Em maior parte, a aula é exposta oralmente. Nos exercícios, ao passo que os } \\
\text { alunos ganham vocabulário, vou inserindo os sinais e frases completas". } \\
\text { "Na avaliação os alunos fazem uma transcrição do que eu interpreto (termos } \\
\text { ou frases) em Libras para a Língua Portuguesa escrita, também há a } \\
\text { transcrição a partir do alfabeto em Libras (impresso) [...] e durante as aulas } \\
\text { entregam um trabalho em vídeo sobre um tema, geralmente, em grupo: } \\
\text { conversação ou música”. } \\
\text { Estratégias metodológicas (plano de ensino): Aulas expositivas teóricas, prática } \\
\text { de Libras (diálogos), apresentação de filmes (documentários), filmes em Libras } \\
\text { e visita a espaços onde se encontram manifestações de Cultura Surda. } \\
\text { Avaliação (plano de ensino): Teórica - análise de filme referente às filosofias } \\
\text { educacionais, estudo de caso, cultura e identidade Surda e o processo de ensino- } \\
\text { aprendizagem. } \\
\text { Prática - alfabeto, números e pessoas, família, dias e meses do ano. }\end{array}$ \\
\hline Bruno & $\begin{array}{l}\text { - Principais conteúdos apontados pelo docente. } \\
\text { “Em primeiro lugar, falar de quem é o surdo, uma pessoa que possui uma } \\
\text { identidade distinta da dos ouvintes e explicar o que é língua de sinais. Muitos } \\
\text { alunos chegam com o conceito do "surdo-mudo”, que a língua de sinais não é } \\
\text { língua (linguagem dos sinais) e que basta você colocar os sinais na estrutura da } \\
\text { língua portuguesa que basta. O primeiro passo é desmistificar este processo. } \\
\text { Em seguida apresentar o alfabeto manual e as configurações de mão. Então } \\
\text { começamos com os cumprimentos, para que os alunos aprendam como fazer um } \\
\text { 'Oi' para o surdo. Em seguida ensino a feitura do endereço, os sinais de cidade, } \\
\text { bairro, etc. Então começamos a abordar os vocábulos de família, Estados, } \\
\text { alimentos, alguns verbos. Procuro também ensinar a gramática, como os tipos }\end{array}$ \\
\hline
\end{tabular}




\begin{tabular}{|c|c|}
\hline & $\begin{array}{l}\text { de verbos, tipos de frase, os negativos em Libras, e o mais importante: as } \\
\text { diferenças entre língua de sinais e língua portuguesa". } \\
\text { • Modalidades linguísticas, estratégias e exercícios propostos. } \\
\text { "As duas [modalidades]. No início falo em português. Em algumas aulas eu } \\
\text { ministro apenas em Libras. Este semestre, por exemplo, no curso de Educação } \\
\text { Física eu ministro as aulas apenas em Libras. Quando os alunos não entendem, } \\
\text { vou à lousa e escrevo a palavra que estava sinalizando. Esta experiência tem } \\
\text { sido muito positiva e tem dado certo. Nas disciplinas optativas, como não } \\
\text { falamos apenas sobre surdez, mas de inclusão de uma maneira geral, acabo } \\
\text { falando em português o tempo todo. No Centro de Línguas, nos dois primeiros } \\
\text { módulos falo metade em português e metade em Libras. A partir do terceiro } \\
\text { (são cinco módulos) as aulas são feitas exclusivamente em Libras”. } \\
\text { “A avaliação fica por conta de uma apresentação em Libras por parte dos } \\
\text { alunos, procurando unir com o curso no qual estão se graduando. Se é uma } \\
\text { sala de aula. } \\
\text { turma de pedagogia, uma música infantil ou uma situação em sala de aula que é } \\
\text { dramatizada em Libras. Se é um curso de Educação Física, um esporte } \\
\text { adaptado para os surdos, também dramatizado em Libras. Já na disciplina } \\
\text { optativa, em que há a presença de vários cursos, os alunos podem escolher uma } \\
\text { música ou um diálogo. Quase sempre a música é a opção”. } \\
\text { Estratégias metodológicas (plano de ensino): Aulas expositivas apresentando a } \\
\text { contribuição do paradigma da inclusão, bem como aulas com o treino de } \\
\text { estratégias de comunicação com a pessoa surda. Utilização de depoimentos e } \\
\text { simulações. Utilização de filmes para discussão em sala de aula. } \\
\text { Avano de ensino): Teórica - individual, em que os alunos irão } \\
\text { imo seriam as iniciativas para a inclusão no bairro em residem; }\end{array}$ \\
\hline Carla & $\begin{array}{l}\text { - Principais conteúdos apontados pela docente. } \\
\text { "Para uma aproximação dos estudantes de graduação com o foco da disciplina }\end{array}$ \\
\hline
\end{tabular}




\begin{tabular}{|c|c|}
\hline & $\begin{array}{l}\text { Libras e Língua Portuguesa na educação de surdos, são priorizados os } \\
\text { seguintes conteúdos: Histórico da educação dos surdos e das abordagens de } \\
\text { comunicação; Mitos e verdades das línguas de sinais; Inclusão educacional em } \\
\text { perspectiva bilíngue; Identidade, cultura e comunidade Surda; A Libras em } \\
\text { suas singularidades linguísticas e seus efeitos sobre o desenvolvimento, } \\
\text { aquisição da Língua Portuguesa e produções culturais; Introdução ao } \\
\text { conhecimento prático da Libras: léxico e noções gramaticais”. } \\
\text { • Modalidades linguísticas, estratégias e exercícios propostos. } \\
\text { "Dentre os objetivos especificados [...], utilizo a Língua Portuguesa para } \\
\text { aqueles de número } 1 \text {, 2, 3, 4, 6, } 7 \text {, e } 8 \text { [se refere aos objetivos sobre os } \\
\text { conteúdos teóricos] e utilizo a Libras para o objetivo } 5 \text { [se refere ao objetivo: } \\
\text { Comunicar-se com sinais básicos da Libras em situações diversas]”. } \\
\text { “Contato com surdos; Proposição de situaçães teórico-práticas que } \\
\text { possibilitem uma vivência com a língua de sinais e com a cultura e identidade } \\
\text { surda”. } \\
\text { Estratégias metodológicas (plano de ensino): O curso contará com contribuições } \\
\text { de especialistas para a parte teórica e prática específicas, com aulas expositivas } \\
\text { e exercícios práticos de Libras; seções de estudo da legislação e das políticas } \\
\text { públicas que envolvem o campo e visita técnica a escola municipal em que se } \\
\text { desenvolve a educação bilíngue Libras/Língua Portuguesa, além de leitura e } \\
\text { discussão de textos previamente indicados. } \\
\text { Avaliação (plano de ensino): a avaliação será feita por meio da participação nas } \\
\text { aulas, frequência dos estudantes e produção de um relatório síntese das } \\
\text { aprendizagens, além de autoavaliação da turma. }\end{array}$ \\
\hline & $\begin{array}{l}\text { - Principais conteúdos apontados pela docente. } \\
\text { “Em termos de léxico verbos, substantivos, adjetivos, advérbios [...]. Uma } \\
\text { quantidade mínima para que esse aluno possa se comunicar e até entender o } \\
\text { funcionamento da língua. [Mas] é tudo contextualizado, [...] vou falando e eles } \\
\text { vão traduzindo, conto pequenos episódios para tradução e priorizo a } \\
\text { conversação para nãoficar o léxico puro. } \\
\text { [Sobre os conteúdos teóricos] [...] a estrutura gramatical da língua de sinais, a }\end{array}$ \\
\hline
\end{tabular}




\begin{tabular}{|c|}
\hline 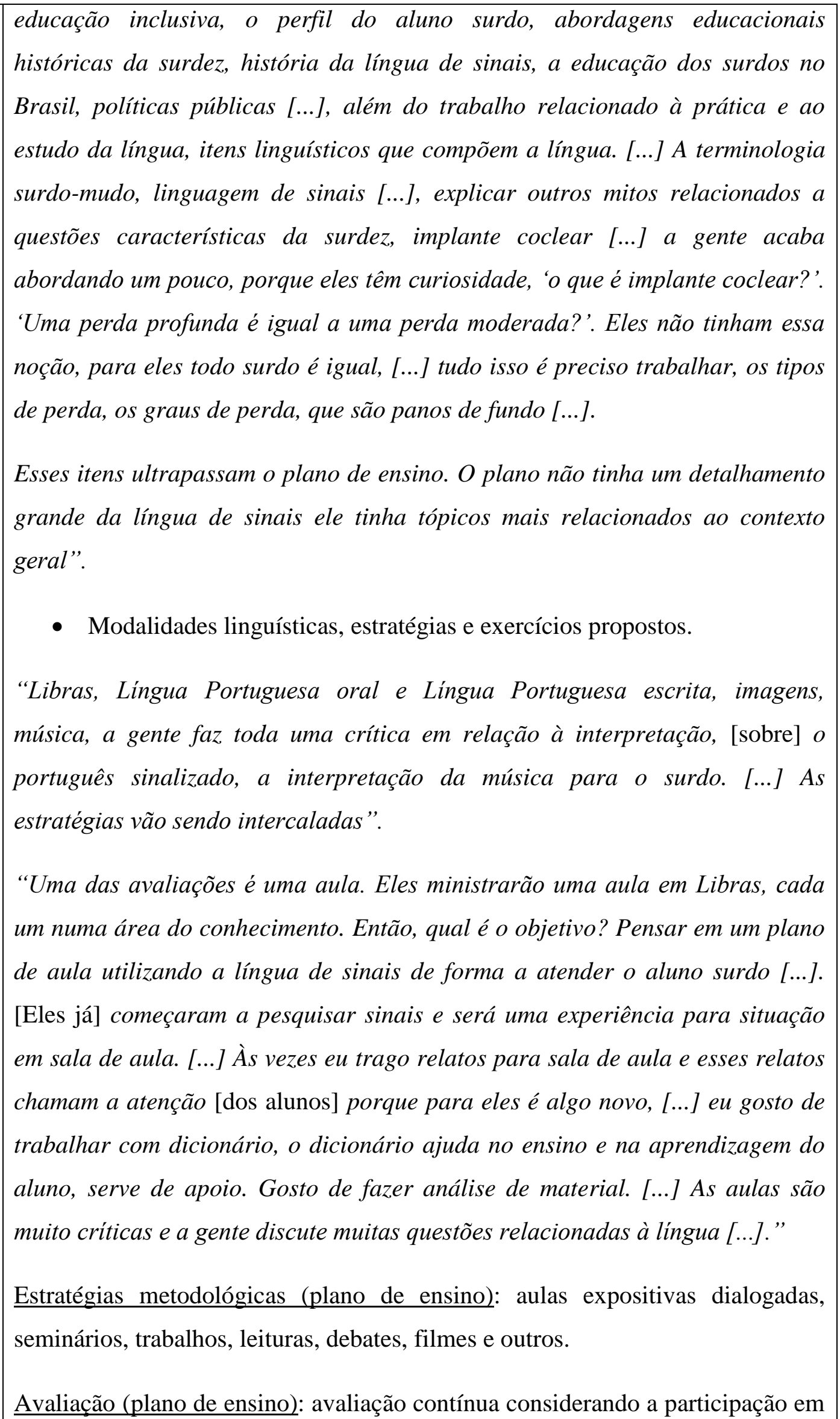 \\
\hline
\end{tabular}




\begin{tabular}{|c|c|}
\hline & $\begin{array}{l}\text { la, assiduidade, realização de trabalhos e relatórios de leitura, provas, } \\
\text { minários, debates, filmes e outros. }\end{array}$ \\
\hline Emília & $\begin{array}{l}\text { • Principais conteúdos apontados pela docente. } \\
\text { “O conhecimento do histórico da educação de surdos é importante para que os } \\
\text { alunos saibam, para que e porque existe esta disciplina no seu currículo, este } \\
\text { conhecimento determina o envolvimento do aluno na disciplina e amplia a } \\
\text { discussão a respeito da língua. Este aspecto está parcialmente contemplado no } \\
\text { plano, no entanto pode ser mais ou menos aprofundado dependendo do } \\
\text { tamanho e envolvimento da turma”. } \\
\text { • Modalidades linguísticas, estratégias e exercícios propostos. } \\
\text { "Nas aulas teóricas a comunicação é por meio da Língua Portuguesa, na } \\
\text { modalidade oral e nas aulas práticas existe uma mescla de momentos: em } \\
\text { alguns a língua de sinais é apresentada sem a língua oral em outros essa é } \\
\text { explicada através da língua oral”. } \\
\text { Estratégias metodológicas (plano de ensino): o curso se centralizará na } \\
\text { apresentação dos aspectos básicos da língua de sinais, com ênfase em ações } \\
\text { interativas. Contação de história e diálogo. } \\
\text { Avaliação (plano de ensino): resenhas críticas; estudo de vídeo (pesquisa de } \\
\text { internet); relatório de fechamento. }\end{array}$ \\
\hline Flávia & $\begin{array}{l}\text { • Principais conteúdos apontados pela docente. } \\
\text { “[...] não podemos deixar de abordar na disciplina a história dos surdos e das } \\
\text { suas conquistas, creio que aula de Libras não é somente 'fazer sinais', mas é } \\
\text { compreender o porquê fazemos e de que forma isto beneficia uma comunidade } \\
\text { diferente da minha”. } \\
\text { • Modalidades linguísticas, estratégias e exercícios propostos. } \\
\text { "Na medida do possível e como trabalho com um surdo procuro suscitar } \\
\text { discussões na classe buscando que os alunos visualizem o conhecimento desse } \\
\text { professor e que ele possa trazer experiências significativas aos alunos, para }\end{array}$ \\
\hline
\end{tabular}




\begin{tabular}{|c|c|}
\hline & $\begin{array}{l}\text { conscientizá-los no seu trabalho como futuros professores [...]. [...] Utilizo } \\
\text { muito a língua de sinais (sem tradução simultânea), em momentos de aula } \\
\text { teórica utilizo a oralidade e tento fazer o bimodalismo quando o professor } \\
\text { surdo está junto”. } \\
\text { "[...] Tento aprofundar o conhecimento dos sinais por meio de histórias e de } \\
\text { apresentações dos alunos com pequenos diálogos”. } \\
\text { Estratégias metodológicas (plano de ensino): Utilização da Libras durante a } \\
\text { aula; narração de histórias; fábulas, notícias de jornal, músicas, poesia em } \\
\text { Libras. DVD e Data show com histórias e conteúdos em Libras. Leitura de } \\
\text { textos teóricos sobre as línguas de sinais. } \\
\text { Avaliação (plano de ensino): prova objetiva; trabalhos gravados em mídias com } \\
\text { apresentação dos alunos em Libras; trabalhos (resenhas, resumos) individuais e } \\
\text { em grupo sobre os conteúdos apresentados em aula. }\end{array}$ \\
\hline & Abordagens sobre a cultura surda \\
\hline Ana & $\begin{array}{l}\text { "Aspectos como aquisição da língua pelo sujeito surdo, história da educação } \\
\text { do surdo, da necessidade de uma educação específica para esta comunidade, os } \\
\text { olhares depositados sobre ela frente uma visão socioantropológica ou } \\
\text { medicalizada da condição da surdez e também o processo de retomada do } \\
\text { poder de escolha deste sujeito surdo sobre o papel que ele mesmo } \\
\text { desempenhará na sociedade. Isso é feito principalmente através de filmes, } \\
\text { documentários e aulas teóricas". }\end{array}$ \\
\hline Bruno & $\begin{array}{l}\text { "Falar de cultura surda é um tanto complicado, porque os próprios autores } \\
\text { divergem sobre este assunto. Procuro apresentar textos de pessoas que } \\
\text { concordam com a existência da cultura surda, nos quais eu me incluo, e } \\
\text { daqueles que não acreditam que ela exista, ou ela seja distinta da dos ouvintes. } \\
\text { Tenho abordado este tema [...] e apresento na visão de Nídia Sá sobre o } \\
\text { multiculturalismo. Muito mais do que apenas apertar a luz para chamar outro } \\
\text { surdo, ou que o toque se faz necessário, abordo com os alunos que a língua de } \\
\text { sinais é o principal meio em que a cultura surda se manifesta. No curso de } \\
\text { jornalismo, fiz um documentário chamado 'Nascidos no Silêncio' em que } \\
\text { abordo a relação entre filhos ouvintes e pais surdos. Ali estão presentes as }\end{array}$ \\
\hline
\end{tabular}




\begin{tabular}{|c|c|}
\hline & $\begin{array}{l}\text { diferenças que existem entre a educação de uma família ouvinte e a educação } \\
\text { de uma família surda. Mostro que os surdos possuem outros valores, não tão } \\
\text { diferentes da pessoa ouvinte, mas que são diferentes e que traz implicações no } \\
\text { desenvolvimento dos filhos destes casais, sejam eles surdos ou ouvintes. } \\
\text { Também cito Stuart Hall, que aborda a questão da identidade nacional e que } \\
\text { culturas muitas vezes são construídas para legitimar a história ou a 'história' } \\
\text { de um povo". }\end{array}$ \\
\hline Carla & $\begin{array}{l}\text { "Para a abordagem desses conteúdos, são discutidas particularidades sobre a } \\
\text { cultura surda apresentadas em referências bibliográficas (muitos delas com a } \\
\text { autoria de surdos), filmes e relatos de surdos". }\end{array}$ \\
\hline Daniela & $\begin{array}{l}\text { “[Houve a abordagem] de questões relacionadas à comunidade, a cultura [...]. } \\
\text { Cultura surda é um conceito muito complexo, se você não tem envolvimento } \\
\text { com a área, se você não acompanha a questão histórica, a questão identitária } \\
\text { do surdo, é um pouco difícil de entender esse conceito. E eu trabalhei com um } \\
\text { livro ['Libras, que língua é essa?’] que aborda essa questão da identidade, da } \\
\text { cultura, que acaba aprofundando essas questões. [...] Num primeiro momento } \\
\text { os alunos tiveram um pouco de dúvida: 'como outra cultura?’A partir do } \\
\text { momento que você começa a trabalhar todas as características, a questão da } \\
\text { identidade, eles começam a entender melhor [...]. } \\
\text { [...] A própria questão da língua, a língua enquanto traço cultural é } \\
\text { importantíssimo, há o destaque sobre as manifestações que ocorrem dentro da } \\
\text { comunidade, a visão de mundo que ocorre por meio do visual. Acho que são } \\
\text { esses três aspectos que abordo mais. [...] A gente tava trabalhando com essas } \\
\text { questões mais teóricas de fundo [...], os alunos estão respondendo, mas estão } \\
\text { vendo que é bem puxado, porque, além disso, a gente foi colocando questões de } \\
\text { gramática, começando o trabalho com a Libras, agora darei [ênfase] na Libras. } \\
\text { [...] Ainda falta o português como segunda língua, que eu também estou } \\
\text { trabalhando, e que é uma discussão muito ampla e complexa [...], outra ideia } \\
\text { de alfabetização, é preciso saber trabalhar com o aluno. Como é que está sendo } \\
\text { o ensino dessa língua como segunda língua, na modalidade escrita e } \\
\text { paralelamente todo o trabalho com a Libras [...]”. }\end{array}$ \\
\hline
\end{tabular}




\begin{tabular}{|c|c|}
\hline Emília & $\begin{array}{l}\text { "[...] considero que a língua sem as relações socioculturais é estanque e } \\
\text { estéril". }\end{array}$ \\
\hline Flávia & $\begin{array}{l}\text { “Falamos da cultura surda, da questão da organização da oração, da forma } \\
\text { diferente de compreender uma notícia ou de como muitas vezes o surdo fica } \\
\text { excluído da sociedade pelo simples fato de que 'ninguém contou para ele a } \\
\text { importância daquele assunto'. Essa abordagem costuma ocorrer com exemplos } \\
\text { vividos pela minha pessoa ou muitas vezes o professor surdo é que vai contanto } \\
\text { como ele compreende o mundo. Tivemos já duas palestras com o professor } \\
\text { surdo com tradução, uma versou sobre a importância da língua de sinais para } \\
\text { os surdos e seus aspectos visuais e a segunda foi sobre literatura surda”. }\end{array}$ \\
\hline \multicolumn{2}{|r|}{ A permeabilidade dos discursos docentes } \\
\hline Ana & $\begin{array}{l}\text { "No decorrer do curso, existe muita surpresa e também solidariedade sobre } \\
\text { aspectos antes desconhecidos da cultura surda, como a origem dos sinais, as } \\
\text { questões de dificuldade comunicacional com familiares, necessidades de } \\
\text { condições específicas de ensino-aprendizagem, mas também paira certa } \\
\text { incompreensão sobre outros aspectos, tais como sobre os grupos rejeitam } \\
\text { terapias e cirurgias corretivas. De forma geral, boa parte dos alunos mostra } \\
\text { interesse em conhecer mais sobre a comunidade surda e sua lingua”. }\end{array}$ \\
\hline Bruno & $\begin{array}{l}\text { "É muito bom ver paradigmas serem desconstruidos e remontados diante dos } \\
\text { seus olhos. Os alunos chegam dizendo várias terminologias que hoje } \\
\text { consideramos erradas, como surdo-mudo, portador de deficiência, entre outros, } \\
\text { e ao final do semestre eles já começam a falar surdo, e pessoa com deficiência. } \\
\text { Já ouvi alunos comentarem que corrigem os colegas que usam a terminologia } \\
\text { errada. Nos textos que me apresentam fica nítida a mudança de pensamento em } \\
\text { relação à inclusão de pessoas com deficiência". }\end{array}$ \\
\hline Carla & $\begin{array}{l}\text { "Inicialmente, suas falas revelam inúmeros mitos relacionados à surdez e à } \\
\text { Libras e o desconhecimento de particularidades relacionadas à cultura e } \\
\text { identidade surda, aspectos esses que são superados ao longo do curso da } \\
\text { disciplina". }\end{array}$ \\
\hline
\end{tabular}




\begin{tabular}{|c|c|}
\hline Daniela & $\begin{array}{l}\text { "[...] O perfil do aluno também é muito interessante, é um aluno que pesquisa, } \\
\text { tem gente que vem por curiosidade e fica para complementar sua matriz } \\
\text { curricular [se referia aos alunos de outros cursos de licenciatura que ainda não } \\
\text { tem a disciplina na grade curricular], então eu acho isso bacana, o fato de estar } \\
\text { vindo por curiosidade, por querer aprender mais. [...] Os alunos da pedagogia } \\
\text { veem como extremamente necessário porque eles irão trabalhar com educação } \\
\text { inclusiva e se depararão um dia com o surdo, na sala de aula ou fora da sala, } \\
\text { então eles acham que precisam desse preparo [...], eles não tinham essa } \\
\text { percepção inicial, agora já tem, [e dizem] 'essa disciplina deveria ter dois } \\
\text { semestres' [...]. } \\
\text { Foi interessante o relato de uma aluna [que já sabe Libras e foi questionada } \\
\text { pela docente quando demonstrou interesse em cursar as aulas como ouvinte]: } \\
\text { 'você sabe qual será o ganho para você nessa disciplina? Eu vou trabalhar } \\
\text { Libras e é um trabalho básico que você já sabe'. Ela falou: 'professora, eu } \\
\text { estou gostando muito porque tem toda uma parte que entra na Libras que eu } \\
\text { não sabia, eu não estudei textos teóricos, eu não tenho essa bagagem, eu só } \\
\text { conheço a parte prática e só conheço a surdez!' E é uma das melhores alunas, } \\
\text { ela já sabe, participa de tudo. Ela é da licenciatura, mas não é da Pedagogia, } \\
\text { ela está como ouvinte na turma. E tem outras também da matemática, de artes, } \\
\text { eles ainda não têm na grade, então eles vieram fazer para o enriquecimento do } \\
\text { currículo. E eles dizem: 'Eu estou gostando porque eu não tive,”. }\end{array}$ \\
\hline Emília & $\begin{array}{l}\text { "De um modo geral existe um desconhecimento a respeito de todos os aspectos } \\
\text { deste grupo [se referia a comunidade surda] e isto determina a motivação para a } \\
\text { aula. o senso comum prevalece e desmitificar isto proporciona uma nova } \\
\text { abordagem dos alunos não somente frente aos surdos como também sobre as } \\
\text { dinâmicas inter-relacionais frente às diferenças. Um exemplo que posso } \\
\text { recordar foi de um aluno que o pai, após a aposentadoria, estava bebendo } \\
\text { muito e se afastando da família. Após uma aula ele relatou que percebeu que o } \\
\text { afastamento do pai não era unilateral, mas que a família o havia afastado por } \\
\text { ele estar apresentando uma perda auditiva que o distanciava da língua e por } \\
\text { consequência das relações. A partir das aulas o discente conseguiu relacionaro }\end{array}$ \\
\hline
\end{tabular}




\begin{tabular}{|l|l|}
\hline & fato não somente como pessoal, mas trouxe reflexões pessoais bastante ricas”. \\
\hline Flávia & "Creio que a maioria dos alunos inicia o semestre letivo tendo algumas ideias \\
& e ao término do mesmo a grande maioria modifica suas perspectivas, porém \\
& ainda ao término alguns continuam achando que 'Libras é bonitinho' e que os \\
& 'surdos-mudos' devem aprender a falar para se comunicar".
\end{tabular}

